\title{
FONTES DE CRESCIMENTO E SISTEMA PRODUTIVO DA ORIZICULTURA NO MATO GROSSO
}

\author{
Paulo Nazareno Alves Almeida
}

Dissertação apresentada à Escola Superior de Agricultura “Luiz de Queiroz”, Universidade de São Paulo, para obtenção do título de Mestre em Ciências, Área de Concentração: Economia Aplicada.

P I R A C I C A B A

Estado de São Paulo - Brasil

Dezembro - 2003 


\title{
FONTES DE CRESCIMENTO E SISTEMA PRODUTIVO DA ORIZICULTURA NO MATO GROSSO
}

\author{
Paulo Nazareno Alves Almeida \\ Engenheiro Agrônomo
}

Orientador: Profa. Dra. MIRIAN RUMENOS PIEDADE BACCHI

\begin{abstract}
Dissertação apresentada à Escola Superior de Agricultura “Luiz de Queiroz”, Universidade de São Paulo, para obtenção do título de Mestre em Ciências, Área de Concentração: Economia Aplicada.
\end{abstract}

P I R A C I C A B A

Estado de São Paulo - Brasil

Dezembro - 2003 
Dados Internacionais de Catalogação na Publicação (CIP) DIVISÃO DE BIBLIOTECA E DOCUMENTAÇÃO - ESALQ/USP

\author{
Almeida, Paulo Nazareno Alves \\ Fontes de crescimento e sistema produtivo da orizicultura no Mato Grosso / Paulo \\ Nazareno Alves Almeida. - - Piracicaba, 2003. \\ 213 p. : il. \\ Dissertação (mestrado) - - Escola Superior de Agricultura Luiz de Queiroz, 2004. \\ Bibliografia. \\ 1. Algodão 2. Competição econômica 3. Crescimento vegetal 4. Geografia \\ econômica 5. Indústria agrícola (economia) 6. Milho 7. Modelos matemáticos 8. \\ Rizicultura 9. Soja I. Título
}

CDD 338.17318

"Permitida a cópia total ou parcial deste documento, desde que citada a fonte - O autor" 
Aos meus pais, Francisco e Ana.

Ao теu irmão, Fabrício.

Às minhas tias, Edileusa e Edineuba.

Ao meu tio, Erisneide.

DEDICO COM IMENSO CARINHO. 


\section{AGRADECIMENTOS}

A Deus, por me guiar neste difícil caminho, pela fé, coragem, vontade e força e por me proporcionar uma família maravilhosa que, em conjunto, ajudou-me a superar os momentos conturbados.

Aos meus pais, Francisco e Ana, a quem dedico muito amor e que não mediram esforços no apoio à minha formação pessoal e cultural, a eles minha profunda

gratidão. Às minhas tias Edileusa e Edineuba pelo apoio fornecidos no decorrer do curso.

À ESALQ e ao Departamento de Economia, Administração e Sociologia pela oportunidade de realização do mestrado. Aos professores desse Departamento pela boa formação acadêmica. Ao Centro de Estudos Avançados em Economia Aplicada Cepea/ESALQ, pela oportunidade de estágio, realização da dissertação e pelo financiamento da mesma.

À Coordenação de Aperfeiçoamento de Pessoal de Nível Superior - Capes, pela concessão da bolsa de estudos.

À Prof ${ }^{\mathrm{a}}$. Dra. Mirian Rumenos Piedade Bacchi, pela orientação, estímulo, confiança e atenção dedicada no decorrer do trabalho. Sua firmeza e segurança nos ensinamentos, além de sua compreensão nos momentos difíceis, foram preponderantes para superar as turbulências.

Ao Prof. Dr. Geraldo Sant’Ana de Camargo Barros, pelas sugestões e confiança em meu trabalho.

Ao Prof. João Gomes Martines Filho, pelas sugestões em diversas fases do estudo. 
Ao grande amigo Prof. Dr. Augusto Hauber Gameiro, que me conduziu a um bom trabalho, sempre com seu olhar perfeccionista e confiança em meu potencial. Ao longo de minha convivência com ele, passei a admirá-lo pela sua competência, alegria e amizade.

Ao Dr. Estevão, pela sólida amizade construída e pela ajuda no entendimento e organização dos dados da dissertação, bem como pela ajuda em outras fases do mestrado.

Ao Magri, Patrício e Emílio, pela amizade e pelas longas conversas as quais foram muito importantes no entendimento do mercado de arroz.

Às pessoas entrevistadas, pelo fornecimento das informações que compuseram os resultados dessa pesquisa.

À Analy, a quem estimo muito carinho e por sua ajuda em importante etapa da dissertação. Ao amigo Lucílio, que me ajudou em diversas etapas do curso e na dissertação. Ao Ricardinho, pelas dicas na organização dos dados. Ao Xaxim, Nailton e Conchas pela amizade. Ao amigos Simão, Mauro, Alexandre e Alessandro por encontrar harmonia no lar nas horas de descanso e por constituirmos uma boa família. Ao Tabajara Vila PG pelos títulos conquistados e descontração nos fins de semana e aos companheiros de futebol.

A todos os amigos cujos nomes não citarei para não cometer injustiças devido ao esquecimento. 


\section{SUMÁRIO}

Página

LISTA DE FIGURAS ................................................................................ viii

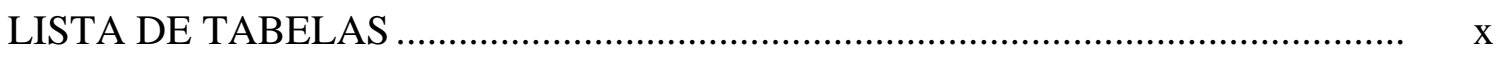

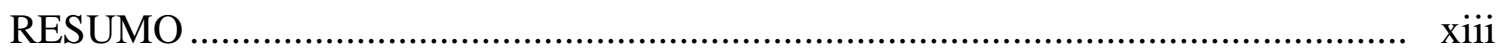

1 INTRODUÇÃ

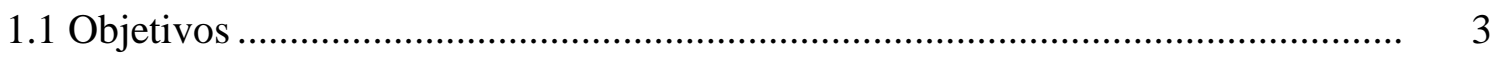

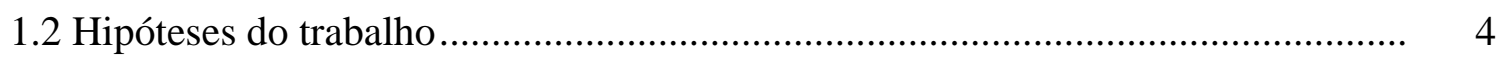

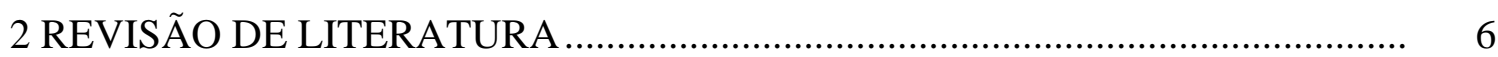

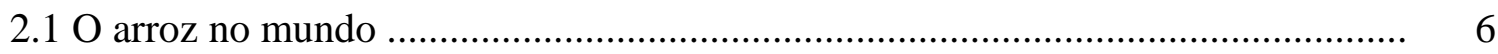

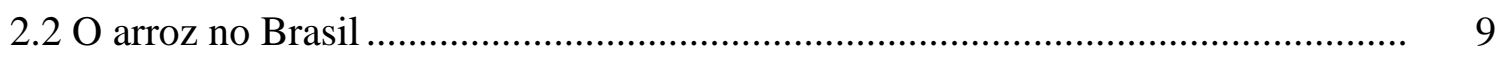

2.3 Fontes de crescimento da produção agrícola ................................................. 22

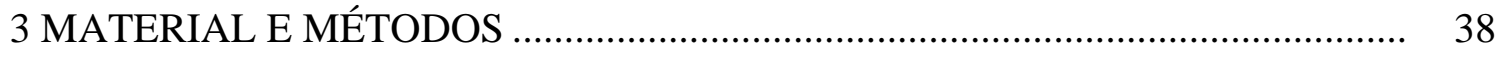

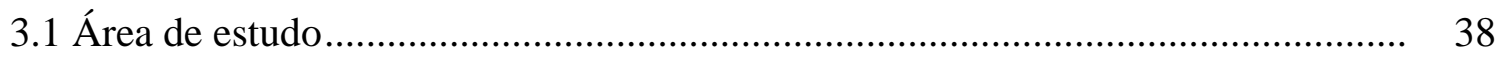

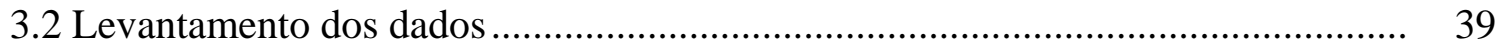

3.3 Descrição do modelo "shift-share” ............................................................... 41

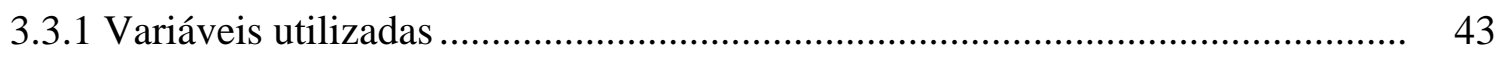

3.3.2 Descrição do modelo matemático .............................................................. 45

3.3.2.1 Análise individual das culturas no Estado do Mato Grosso........................... 45

3.3.2.1.1 Formulação matemática para apresentação dos resultados ......................... 48

3.3.2.1.2 Decomposição do efeito área em efeitos escala e substituição.................... 50

3.3.2.2 Análise do conjunto de culturas por microrregião ...................................... 52

3.3.2.3 Análise do conjunto de culturas no estado ............................................... 54

3.4 Sistema de produção ................................................................................. 57

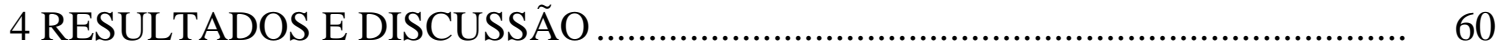


4.1 Descrição do sistema produtivo ……………………......................................... 60

4.1.1 Região norte mato-grossense .......................................................................... 71

4.1.2 Região central mato-grossense......................................................................... 77

4.1.3 Região leste mato-grossense ……………………………………………….... 87

4.1.4 Região oeste mato-grossense .......................................................................... 92

4.1.5 Considerações complementares .................................................................. 96

4.2 Agroindústria ……………………................................................................ 99

4.3 Expansão e substituição de culturas ................................................................... 103

4.4 Análise individual das culturas no Estado do Mato Grosso................................... 107

4.5 Análise do conjunto de culturas por microrregião .................................................. 116

4.6 Análise do conjunto de culturas no Estado do Mato Grosso .................................. 138

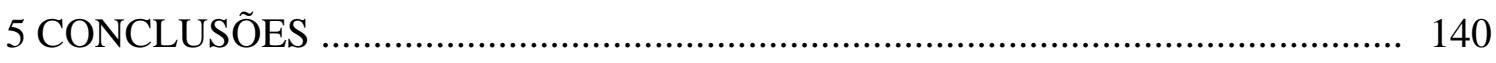

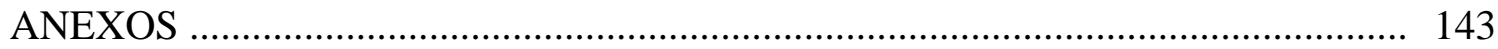

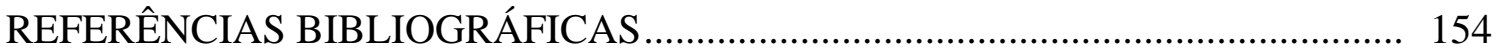

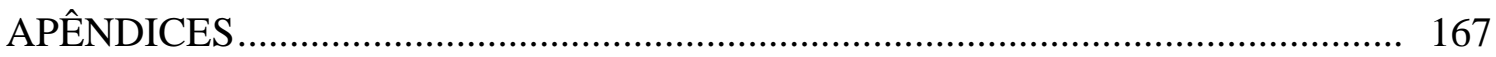




\section{LISTA DE FIGURAS}

Página

1 Produção e área colhida de arroz no Brasil................................................ 10

2 Produção e área de arroz de terras altas e irrigado........................................ 16

$3 \quad$ Produtividade do arroz de terras altas e do irrigado......................................... 17

$4 \quad$ Evolução de recursos de crédito rural, de 1969 a 2001.................................... 24

5 Evolução da área mato-grossense de algodão, arroz, milho e soja .................... 64

6 Índice da evolução da área mato-grossense de algodão, arroz, milho e soja ...... 65

7 Produção mato-grossense de algodão, arroz, milho e soja................................ 66

8 Índice de evolução da produção mato-grossense de algodão, arroz, milho e

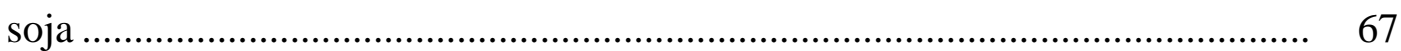

$9 \quad$ Produção agrícola da região norte mato-grossense ......................................... 73

10 Índice da produção de culturas da região norte mato-grossense........................ 74

11 Área de culturas na região norte mato-grossense......................................... 75

12 Índice de área das culturas na região norte mato-grossense ............................ 76

13 Evolução da produção de algodão, arroz, milho e soja na região central do Mato

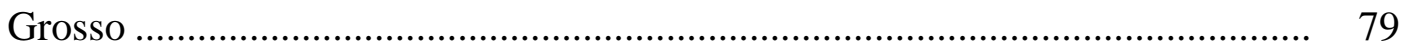

14 Índice de produção das culturas na região central mato-grossense.................... 80

15 Evolução da área de algodão, arroz, milho e soja na região central do Mato

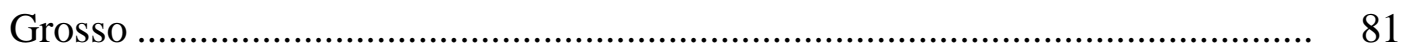

16 Índice de área das culturas na região central mato-grossense........................... 82

17 Evolução da produção de algodão, arroz, milho e soja na região leste do Mato

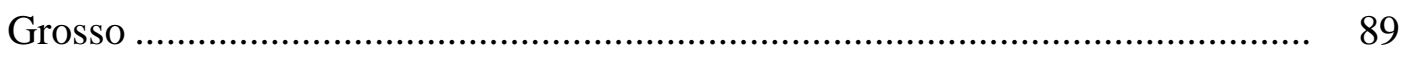

18 Índice de produção das culturas na região leste mato-grossense ....................... 90 
19 Evolução da área de algodão, arroz, milho e soja na região leste do Mato

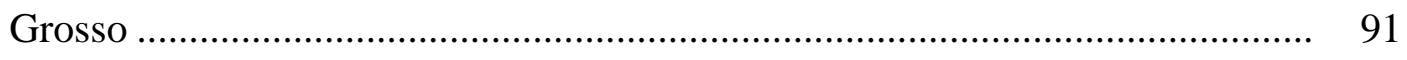

20 Índice de área das culturas na região leste mato-grossense ............................ 92

21 Comportamento da produção de culturas selecionadas na região oeste, de 1990

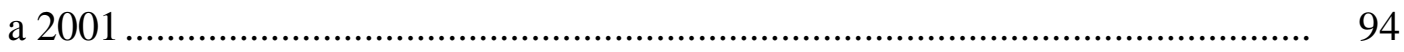

22 Índice de produção das culturas na região oeste mato-grossense ...................... 94

23 Evolução da área de algodão, arroz, milho e soja na região oeste do Mato

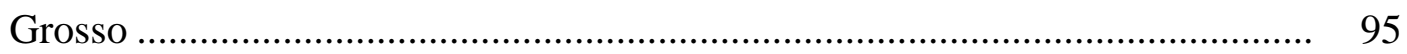

24 Índice de área das culturas na região oeste mato-grossense ........................... 96

25 Preços recebidos pelos produtores de algodão, arroz, milho e soja do Mato

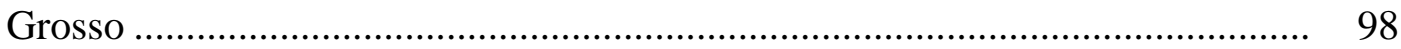




\section{LISTA DE TABELAS}

Página

1 Produção e consumo (mundial e per capita) do arroz em casca, milho e trigo,

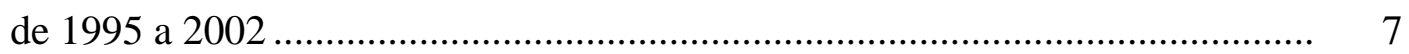

2 Maiores produtores mundiais de arroz e consumo per capita........................... 8

3 Importações brasileiras de arroz proveniente do Mercosul e total importado pelo país (em toneladas) ........................................................................ 11

4 Produção brasileira de arroz da safra 1985/86 a 2001/02, em mil toneladas ...... 13

5 Área colhida de arroz no Brasil da safra 1985/86 a 2001/02, em mil hectares... 14

$6 \quad$ Variedades de arroz de terras altas lançadas na década de 1990 ....................... 18

$7 \quad$ Valor bruto da produção agrícola brasileira em 2001 ..................................... 20

8 Balanço de oferta e demanda de arroz no Brasil (em mil t) .............................. 21

9 Área colhida de arroz (em ha) das 10 maiores microrregiões cultivadoras de arroz do Mato Grosso, de 1996 a 2001 ..................................................... 61

10 Produção de arroz (em toneladas) das 10 principais microrregiões produtoras do Estado do Mato Grosso, de 1996 a 2001 ................................................... 62

11 Participação percentual de cultivares de arroz na safra 2001/02 no Mato Grosso

12 Percentual das variedades cultivadas de arroz no município de Sorriso, nas safras 1999/00, 2000/01 e 2001/02

13 Percentual das variedades cultivadas de arroz no município de Sinop nas safras de 1999/00, 2000/01 e 2001/02.

14 Limites máximos de tolerância de defeitos (\%) para enquadramento do arroz beneficiado polido em tipo comercial 
15 Decomposição do efeito área em efeitos escala e substituição no Mato Grosso, de 1980 a 2000

16 Decomposição do efeito área em efeitos escala e substituição no Mato Grosso, de 1980 a 1985

17 Decomposição do efeito área em efeitos escala e substituição no Mato Grosso, de 1985 a 1990

18 Decomposição do efeito área em efeitos escala e substituição no Mato Grosso, de 1990 a 1995.

19 Decomposição do efeito área em efeitos escala e substituição no Mato Grosso, de 1995 a 2000

20 Taxa média anual de crescimento, efeitos área, rendimento e localização geográfica das culturas do algodão, arroz, milho e soja no Mato Grosso, de 1980 a 2000

21 Taxa média anual de crescimento, efeitos área, rendimento e localização geográfica das culturas do algodão, arroz, milho e soja no Mato Grosso, de 1980 a 1985

22 Taxa média anual de crescimento, efeitos área, rendimento e localização geográfica das culturas do algodão, arroz, milho e soja no Mato Grosso, de 1985 a 1990

23 Taxa média anual de crescimento, efeitos área, rendimento e localização geográfica das culturas do algodão, arroz, milho e soja no Mato Grosso, de 1990 a 1995

24 Taxa média anual de crescimento, efeitos área, rendimento e localização geográfica das culturas do algodão, arroz, milho e soja no Mato Grosso, de 1995 a 2000

25 Decomposição da taxa média anual de crescimento do valor da produção das microrregiões e do estado, em efeitos explicativos no período de 1980 a 2000. 117 
26 Decomposição da taxa média anual de crescimento do valor da produção das microrregiões e do estado, em efeitos explicativos no período de 1980 a 1985.118

27 Decomposição da taxa média anual de crescimento do valor da produção das microrregiões e do estado, em efeitos explicativos no período de 1985 a 1990. 119

28 Decomposição da taxa média anual de crescimento do valor da produção das microrregiões e do estado, em efeitos explicativos no período de 1990 a 1995.120

29 Decomposição da taxa média anual de crescimento do valor da produção das microrregiões e do estado, em efeitos explicativos no período de 1995 a 2000. 121 


\title{
FONTES DE CRESCIMENTO E SISTEMA PRODUTIVO DA ORIZICULTURA NO MATO GROSSO
}

\author{
Autor: PAULO NAZARENO ALVES ALMEIDA \\ Orientador: Profa. Dra. MIRIAN RUMENOS PIEDADE BACCHI
}

\section{RESUMO}

O presente trabalho tem como objetivo descrever o sistema produtivo e quantificar as fontes de crescimento da orizicultura no Mato Grosso, em competição com a cotonicultura, a milhocultura e a sojicultura, no período de 1980 a 2001. Nota-se grandes avanços tecnológicos empregados na cultura do arroz sob o sistema terras altas, diminuindo a diferença produtiva entre este e o arroz irrigado. Diante destas alterações e da carência de informações no tocante ao cultivo de terras altas, são necessários estudos que demonstrem essas alterações de forma sistematizada. Utilizou-se a metodologia "shift-share” na mensuração das fontes de crescimento das atividades agrícolas, tendo como fatores explicativos da evolução da produção os efeitos área, rendimento, composição da produção e localização geográfica. As alterações na área cultivada das culturas foram quantificadas pelos efeitos escala e substituição, realizadas na análise individual por cultura. Com enfoque no arroz, as demais culturas estudadas foram o algodão, o milho e a soja, escolhidas por competirem em maior grau com o arroz na ocupação da área agrícola. Apesar das pastagens apresentarem grande relação com a orizicultura, estas não foram incluídas no estudo, devido à ausência de informações referentes à área e ao rendimento para as microrregiões em todo o período. Verificou-se 
que o arroz de terras altas continua carregando o estigma de abertura de área para domesticação da terra e posterior substituição pela cultura da soja ou pastagens. A orizicultura tem seu uso também relacionado à recuperação de pastagens e rotação com soja. As culturas do algodão e do milho pouco se relacionam diretamente com o arroz, ao contrário da soja e das pastagens. Constataram-se alguns entraves ao desenvolvimento da orizicultura no estado, como a oferta insuficiente de sementes, problemas de mistura varietal na principal variedade cultivada no estado, assim como a falta de estrutura de secagem e armazenagem própria dos produtores, ocasionando dificuldades na comercialização. Todas as culturas analisadas tiveram crescimento da produção de 1980 a 2001. A cultura do arroz apresentou crescimento da produção à taxa de 2,4\% a.a., devido aos efeitos rendimento e localização geográfica, enquanto o efeito área foi negativo à taxa de $0,99 \%$ a.a.. A cultura do arroz foi a única a ceder área agrícola para as demais culturas (208.003 ha), na década de 1980. Os efeitos composição da produção ( $4,56 \%$ a.a.) e área ( $4,04 \%$ a.a.) foram os mais importantes na explicação do crescimento do valor da produção das culturas no estado no período de 1980 a 2000; os efeitos rendimento e localização geográfica também foram positivos. Esses resultados indicam que o crescimento do valor da produção decorre de uma alteração na composição das culturas, ao se substituir ou aumentar a área plantada com culturas mais rentáveis, e decorre também da incorporação de novas áreas, verificada na década de 1990. A elevação do rendimento (3,83\% a.a.) indica o aumento da produtividade das culturas e o efeito localização geográfica (0,72\% a.a.) denota a mudança de cultivo para regiões que apresentam melhores condições de cultivo, como solo e condições climáticas. 


\title{
SOURCES OF GROWTH AND THE PRODUCTIVE SYSTEM OF RICE CROPS IN THE STATE OF MATO GROSSO
}

\author{
Author: PAULO NAZARENO ALVES ALMEIDA \\ Advisor: Prof. Dr. MIRIAN RUMENOS PIEDADE BACCHI
}

\section{SUMMARY}

The current study aims to describe the rice production system and to quantify its sources of growth in the state of Mato Grosso, while competing with cotton, corn and soybean crops, between 1980 and 2001. Great technological advances have been observed in upland rice growing, reducing productive differences between the upland and the irrigated rice. In face of these changes and the lack of information regarding the upland rice, studies showing these alterations in a systematized way are required. The shift-share approach was used to measure the sources of growth of agricultural activities, having as determining factors of production increase the area, yield, crop combination and geographical location effects. Changes in the cultivated area were quantified by the scale and substitution effects, in the individual analysis by culture. Cotton, corn, soybean and rice were the cultures studied, with emphasis to the last one. They were chosen due to the large degree of competition with rice in the utilization of the agricultural area. Despite the strong relation between rice and pastures, they were not included in this study. It is due to the lack of information regarding the area and the yield of pastures in those micro-regions, during the analyzed period. It was observed that the upland rice still has a stigma of opening up rural areas, for 
domestication of land and following substitution by soybean plantation or pasture. Rice growing is also related to pasture recovery and soybean rotation. Its relation with corn and cotton growing, in turn, is not as direct. Some obstacles to the development of rice cultivation in the state of Mato Grosso were detected. As examples: the insufficient supply of seeds; varietal mixture problems in the major variety cultivated in the state; the lack of drying and storage structures for the growers, which hampers commercialization. All of the cultures analyzed registered an increase of production from 1980 to 2001. Rice production grew at an annual average rate of $2.4 \%$, due to yield and geographical location effects, while the area effect was negative by $0.99 \%$ per year. Rice was the only culture that transferred agricultural area to the others (208,003 ha) in the eighties. The crop combination (4.56\% per year) and the area (4.04\% per year) effects were the most important effects in the explanation of production value growth of these crops, from 1980 to 2000, in Mato Grosso. Yield and geographical location effects were also positives. These results indicate that the production value growth derives from an alteration in crops combination - when the plantation is substituted or the area cultivated with a more profitable culture is expanded. It derives, as well, from the aggregation of new areas, as observed in the nineties. The increase of yield (3.83\% per year) indicates the growth of these crops productiveness. The geographical location effect $(0.72 \%$ per year) denotes a move of the cultivation to regions that present better growing conditions, as soil and weather conditions. 


\section{INTRODUÇÃO}

As mudanças econômicas e políticas ocorridas nos últimos anos afetaram o agronegócio de uma forma geral. Comportamentos típicos de um ambiente inflacionário e fechado à concorrência internacional foram rapidamente modificados. Novos conceitos

e ações ganharam espaço no contexto atual, em que alta produtividade, baixos custos e maior eficiência surgem como regras de sobrevivência no mercado globalizado. Os reflexos sobre a cultura do arroz de terras altas, denominação atual do termo "arroz de sequeiro", foram bastante significativos, pois os avanços tecnológicos permitiram a diminuição da diferença de produtividade entre esse tipo de cultivo e o arroz irrigado. Muitas mudanças foram sentidas pelos atores da cadeia e, portanto, são necessários estudos que mostrem essas alterações de forma sistematizada, que sirvam de ferramenta para diagnosticar a capacidade dos produtores em atender à demanda interna. Percebe-se uma carência de informações no tocante ao sistema de cultivo de terras altas, de modo que ainda não se sabe como as relações na cadeia produtiva são afetadas. De maneira geral, este estudo caracteriza e mostra a evolução da orizicultura no Mato Grosso. Pretende-se realizar no trabalho um estudo das fontes de crescimento da orizicultura nesse estado, utilizando a metodologia "shift-share", além de descrever o sistema produtivo do arroz em regiões selecionadas do estado.

O arroz é um cereal de suma importância na dieta alimentar da população brasileira, fornecendo calorias e proteínas de grande valor nutritivo. É considerado pelo governo brasileiro um produto de segurança alimentar, o que justifica a intervenção no mercado, objetivando a garantia de preços ao produtor e o abastecimento da população. Dados do Instituto Brasileiro de Geografia e Estatística - IBGE (2003a) demonstram que 
o arroz constitui-se no segundo alimento mais consumido pelos brasileiros, sendo superado apenas pelo leite.

O setor orizícola responde por $6 \%$ do valor bruto da produção agrícola nacional, perdendo apenas para a cultura da soja, milho e cana-de-açúcar (IBGE, 2003b).

Segundo a FAO (2003) e a Companhia Nacional de Abastecimento - Conab (2002), o Brasil é o décimo maior produtor mundial de arroz e o maior produtor fora do continente asiático, sendo colhidos 10,656 milhões de toneladas em 2002, representando 1,8\% da produção mundial. O arroz é cultivado em todo o território nacional, sendo dois os sistemas básicos de produção: arroz irrigado e de terras altas. O cultivo irrigado é conduzido com alta tecnologia, produtividade e uniformidade dos grãos. Já no cultivo de terras altas, a utilização de tecnologia é menor, a produtividade é mais baixa e a variação no padrão dos grãos é maior; contudo, este vem evoluindo significativamente nos últimos anos.

A região Sul é a principal produtora de arroz do país, respondendo por mais de 60\% da produção nacional. Destacam-se o Rio Grande do Sul, com a maior produção, e Santa Catarina, com a maior produtividade. Esses estados utilizam tradicionalmente o sistema irrigado. O Centro-Oeste é o segundo maior produtor, respondendo por $15 \%$ da produção brasileira. Nessa região, o Mato Grosso tem grande importância, sendo o principal produtor regional e o segundo maior produtor nacional. Excetuando os da região Sul, os demais estados brasileiros cultivam arroz basicamente sob o sistema de terras altas, representando cerca de 40\% da produção interna (Conab, 2002).

Dada a grande extensão do território mato-grossense e a diversidade dos sistemas de produção adotados em várias localidades, consideram-se no estudo de caracterização da produção de arroz oito microrregiões de grande importância para a cadeia produtiva desse cereal no estado: Alto Teles Pires, Sinop, Colíder, Canarana, Paranatinga, Parecis, Alta Floresta e Primavera do Leste. De modo a gerar resultados menos genéricos, estas estão agrupadas em quatro regiões, conforme semelhanças no sistema de produção, a saber: norte (Colíder e Alta Floresta), centro (Alto Teles Pires e Sinop), leste (Canarana, Paranatinga e Primavera do Leste) e oeste (Parecis). Estas 
microrregiões estão representadas pelos seguintes municípios: Água Boa, Alta Floresta, Campos de Júlio, Cláudia, Colíder, Comodoro, Diamantino, Guarantã do Norte, Lucas do Rio Verde, Matupá, Nova Canaã do Norte, Nova Mutum, Nova Ubiratã, Novo Mundo, Paranatinga, Peixoto de Azevedo, Primavera do Leste, Querência, Santa Carmem, Sinop, Sorriso, Tapurah, Terra Nova do Norte e Vera, nos quais foram aplicados questionários aos agentes da cadeia, objetivando conhecer o perfil da atividade (Anexos A e B). Descreve-se no Apêndice 1 as microrregiões do Estado do Mato Grosso e seus respectivos municípios. A análise de "shift-share” foi aplicada na mensuração das fontes de crescimento das culturas do algodão, arroz, milho e soja no Mato Grosso e em suas 22 microrregiões.

\subsection{Objetivos}

A cultura do arroz de terras altas na região central do Brasil passou por um processo evolutivo com o desenvolvimento de novas variedades e novos sistemas de cultivo. Diante das mudanças ocorridas, vários questionamentos vêm à tona. Como se comporta a produção de arroz no Mato Grosso? Ainda prevalece a condição de cultura desbravadora? Como o arroz interage com as principais culturas do estado? Enfim, como a produção de arroz está inserida no Mato Grosso?

O arroz de terras altas tem evoluído sobremaneira nos últimos anos, verificando-se redução na diferença tecnológica entre ele e o arroz irrigado. No presente estudo analisou-se a evolução da cultura do arroz em competição com a cultura do milho, da soja e do algodão, que são concorrentes do arroz em área em diversos

municípios do Mato Grosso. Exclui-se do estudo as matas e as pastagens pela imprecisão das estimativas de áreas alocadas para essas atividades, mesmo sabendo-se que há uma grande concorrência em relação a esse fator de produção entre esses dois setores da agropecuária.

Têm-se como objetivos específicos analisar: 
- o comportamento da produção de arroz por meio do cálculo e decomposição das taxas médias anuais de variação na produção, subdivididas em efeitos área, produtividade, localização geográfica e composição da produção;

- decompor o efeito área em efeitos escala e substituição para determinar em que medida a variação da área ocorre por expansão, retração ou ainda pela substituição de uma lavoura por outra;

- descrever o sistema de produção de arroz no Mato Grosso e a relação da orizicultura com outras culturas competidoras em área.

Os resultados obtidos fornecem um mapeamento da evolução da produção de arroz com base em crescimento de área cultivada, produtividade, localização geográfica e composição da produção regional.

\subsection{Hipóteses do trabalho}

A hipótese a ser testada na dissertação é que a principal fonte de crescimento da produção da orizicultura mato-grossense foi a expansão de área, devido ao caráter de abertura de novas fronteiras agrícolas. Esse processo foi mais marcante na década de 1980, sendo que a partir da década de 1990 o principal componente explicativo do aumento da produção foi o aumento da produtividade. Outra hipótese seria a de que atualmente a cultura vem se apresentando em sistemas de rotação com outras atividades agrícolas e/ou pecuárias, estabelecendo-se com sustentabilidade dentro do panorama agropecuário do estado, como indicativo da evolução da cultura devido às inovações tecnológicas ocorridas nas últimas duas décadas.

A dissertação está estruturada da seguinte forma: esse capítulo introdutório apresenta as razões do estudo, os objetivos do trabalho e algumas características de produção do mercado de arroz brasileiro. Tem-se no segundo capítulo uma breve revisão de literatura sobre a economia brasileira direcionada ao setor agrícola; são relatados alguns estudos que tratam da evolução da agricultura, tendo-se como fontes explicativas 
os efeitos área, rendimento, localização geográfica e composição da produção. Neste capítulo, comenta-se também sobre a produção de arroz no mundo e no Brasil. O terceiro capítulo é dedicado à descrição das metodologias utilizadas no estudo, bem como à descrição da área de estudo e das fontes dos dados. O capítulo quatro é destinado à apresentação dos resultados provenientes das análises feitas, bem como à discussão dos mesmos, procurando compará-los a outros estudos realizados, de modo a fornecer análises concretas para que se possa elaborar conclusões sobre o que foi discutido. Finalmente, no quinto capítulo, são apresentadas as conclusões do trabalho. 


\section{REVISÃO DE LITERATURA}

\subsection{0 arroz no mundo}

O arroz é um dos mais antigos alimentos produzidos pelo homem. Relata-se que na China 3000 a.C. havia uma cerimônia de semeadura do arroz presidida pelo imperador. Esse cereal tem um importante papel na alimentação humana, sendo os seus maiores consumidores e produtores os países asiáticos.

O arroz constitui-se no segundo cereal mais produzido mundialmente, perdendo apenas para o milho, e é o terceiro cereal mais consumido em todo o mundo, sendo precedido pelo milho e pelo trigo. Percebe-se, na Tabela 1, um crescimento da produção mundial de arroz em casca, nos últimos sete anos, da ordem de $7 \%$. $\mathrm{Na}$ maioria dos vinte principais países produtores, o crescimento ocorreu de forma significativa. O consumo agregado mundial e per capita dos três principais cereais (arroz, milho e trigo) também teve aumento ao longo do período, no entanto, o incremento do consumo per capita de arroz foi bastante modesto, 0,2\% a.a.. Nas safras 1995/96, 1999/00 e 2000/01, o arroz foi o cereal mais produzido em todo o mundo. Observando a Tabela 1, nota-se uma disparidade entre os valores de produção e consumo mundial. Vale alertar para o fato de a produção de arroz referir-se ao cereal com casca, o qual obviamente não é consumido como produto final. Segundo Estados Unidos (2002), nas três últimas safras houve uma redução da produção mundial em 3\%, decorrente principalmente de problemas climáticos e econômicos. 
Tabela 1. Produção e consumo (mundial e per capita) do arroz em casca, milho e trigo, de 1995 a 2002.

\begin{tabular}{|c|c|c|c|c|}
\hline Produtos & Safra & Produção* & Consumo* & Consumo per capita** \\
\hline \multirow{7}{*}{ Arroz } & $1995 / 96$ & 551.324 & 370.222 & 64,2 \\
\hline & $1996 / 97$ & 563.571 & 376.793 & 64,4 \\
\hline & $1997 / 98$ & 574.176 & 377.195 & 63,7 \\
\hline & 1998/99 & 585.586 & 386.673 & 64,4 \\
\hline & $1999 / 00$ & 608.861 & 395.719 & 65,1 \\
\hline & $2000 / 01$ & 591.952 & 393.783 & 64,0 \\
\hline & $2001 / 02$ & 590.585 & 409.612 & 65,7 \\
\hline \multirow{7}{*}{ Milho } & $1995 / 96$ & 517.196 & 537.375 & 93,15 \\
\hline & $1996 / 97$ & 592.048 & 564.281 & 96,51 \\
\hline & $1997 / 98$ & 575.081 & 578.262 & 97,60 \\
\hline & 1998/99 & 605.516 & 581.833 & 96,93 \\
\hline & $1999 / 00$ & 606.671 & 598.927 & 98,51 \\
\hline & $2000 / 01$ & 585.923 & 603.850 & 98,07 \\
\hline & 2001/02 & 593.393 & 618.908 & 99,28 \\
\hline \multirow{7}{*}{ Trigo } & $1995 / 96$ & 538.410 & 547.136 & 94,8 \\
\hline & 1996/97 & 581.993 & 569.605 & 97,4 \\
\hline & 1997/98 & 610.150 & 582.450 & 98,3 \\
\hline & 1998/99 & 589.660 & 581.424 & 96,9 \\
\hline & 1999/00 & 586.183 & 585.384 & 96,3 \\
\hline & $2000 / 01$ & 583.816 & 589.177 & 95,7 \\
\hline & $2001 / 02$ & 578.849 & 586.787 & 94,1 \\
\hline
\end{tabular}

Fonte: Estados Unidos (2002)

* Valores em mil toneladas

** Valores em kg por ano 
A China destaca-se como o principal produtor mundial de arroz, com uma produção de 177,589 milhões de toneladas métricas em 2002, representando 30,6\% da produção mundial (FAO, 2003). Os maiores países produtores são também os maiores consumidores, destacando-se o Myanmar com um consumo per capita de 207,9 kg por ano (Tabela 2).

Tabela 2. Maiores produtores mundiais de arroz e consumo per capita.

\begin{tabular}{cccc}
\hline Países & Produção $(\mathrm{t})^{*}$ & $\%$ & Consumo per capita $(\mathrm{kg})^{* *}$ \\
\hline China & 177.589 .000 & 30,6 & 90,1 \\
Índia & 123.000 .000 & 21,2 & 75,7 \\
Indonésia & 48.654 .048 & 8,4 & 151,1 \\
Bangladesh & 39.000 .000 & 6,7 & 156,5 \\
Vietnã & 31.319 .000 & 5,4 & 170,3 \\
Tailândia & 27.000 .000 & 4,7 & 109,1 \\
Myanmar & 21.200 .000 & 3,7 & 207,9 \\
Filipinas & 12.684 .800 & 2,2 & 101,8 \\
Japão & 11.264 .000 & 1,9 & 59,4 \\
Brasil & 10.489 .400 & 1,8 & 39,1 \\
Mundo & 579.476 .722 & 100 & 57,6 \\
\hline
\end{tabular}

Fonte: FAO (2003)

* Os dados referem-se ao ano de 2002

** Os dados referem-se ao ano de 2000

O comércio internacional de arroz é bastante reduzido, sendo a produção toda basicamente destinada ao consumo interno. Estimativas dos Estados Unidos (2002) para o comércio internacional do arroz, na safra 2001/02, apontam uma movimentação de apenas 25,2 milhões de toneladas. No mesmo ano-safra, a produção mundial foi de 579,477 milhões de toneladas (FAO, 2003). 
Estimativas do International Rice Research Institute - IRRI (1994) indicam que em 2025 serão necessárias 760 milhões de toneladas para abastecer a população mundial. A produção global, atualmente ao redor de 579,5 milhões de toneladas, terá então de aumentar 180,5 milhões de toneladas, sendo que os maiores produtores mundiais enfrentam problemas relacionados à expansão da área agrícola e ao esgotamento dos recursos naturais. O mesmo estudo relata que em 2025 a população brasileira será de 237 milhões de habitantes e que o abastecimento interno estará comprometido caso o Brasil não produza cerca de 16 milhões de toneladas, devendo para tanto obter um acréscimo de aproximadamente cinco milhões de toneladas. Para conseguir esse aumento, deve-se estimular a produção por meio da manutenção dos mecanismos atuais de comercialização, manter e/ou criar outros instrumentos para o crédito rural, propiciar o acesso a novas tecnologias de produção e promover o intercâmbio entre a pesquisa e a extensão rural.

\subsection{O arroz no Brasil}

O arroz é o cereal mais consumido no Brasil, sendo apreciado pela população de todas as camadas sociais, desempenhando papel fundamental na dieta humana por sua proteína conter oito aminoácidos essenciais para o balanceamento nutricional. A união arroz e feijão, além de culturalmente ser a base alimentar da população brasileira, configura-se como uma complementação eficiente. O arroz é pobre no aminoácido essencial lisina e rico em cisteína e metionina; o feijão, por sua vez, é rico em lisina e pobre nos outros dois aminoácidos citados (Juliano et al., 1987). O arroz é considerado uma fonte excelente de carboidrato, contendo quantidades desprezíveis de gordura e colesterol (Castro et al., 1999).

O Brasil é o único país não asiático a figurar entre os dez maiores produtores de arroz, sendo responsável por 1,8\% da produção mundial (Tabela 2). Os países asiáticos, tidos como os principais produtores, concentram aproximadamente $85 \%$ da 
produção mundial. Analisando os dados da Tabela 2 em termos de consumo, percebe-se que o Brasil está bem aquém de outros países.

A produção brasileira passou de 7,967 milhões de toneladas na safra 1989/90 para 10,656 milhões de toneladas em 2001/02 (Figura 1). O Mercosul exerce um importante papel no abastecimento do mercado brasileiro, pois, apesar do crescimento de 33,8\% da produção nacional na década de 1990, o Brasil sempre foi importador líquido de arroz. Segundo Brasil (2003) os países integrantes do referido bloco têm grandes vantagens comerciais e são responsáveis por quase toda a importação de arroz feita pelo Brasil, cerca de 730 mil toneladas atualmente (base casca). O Uruguai é o principal exportador, seguido pela Argentina e Paraguai. Na Tabela 3 são apresentados os volumes de arroz importados pelo Brasil, por países de origem, no âmbito do Mercosul, para o período compreendido entre os anos de 1997 e 2002.

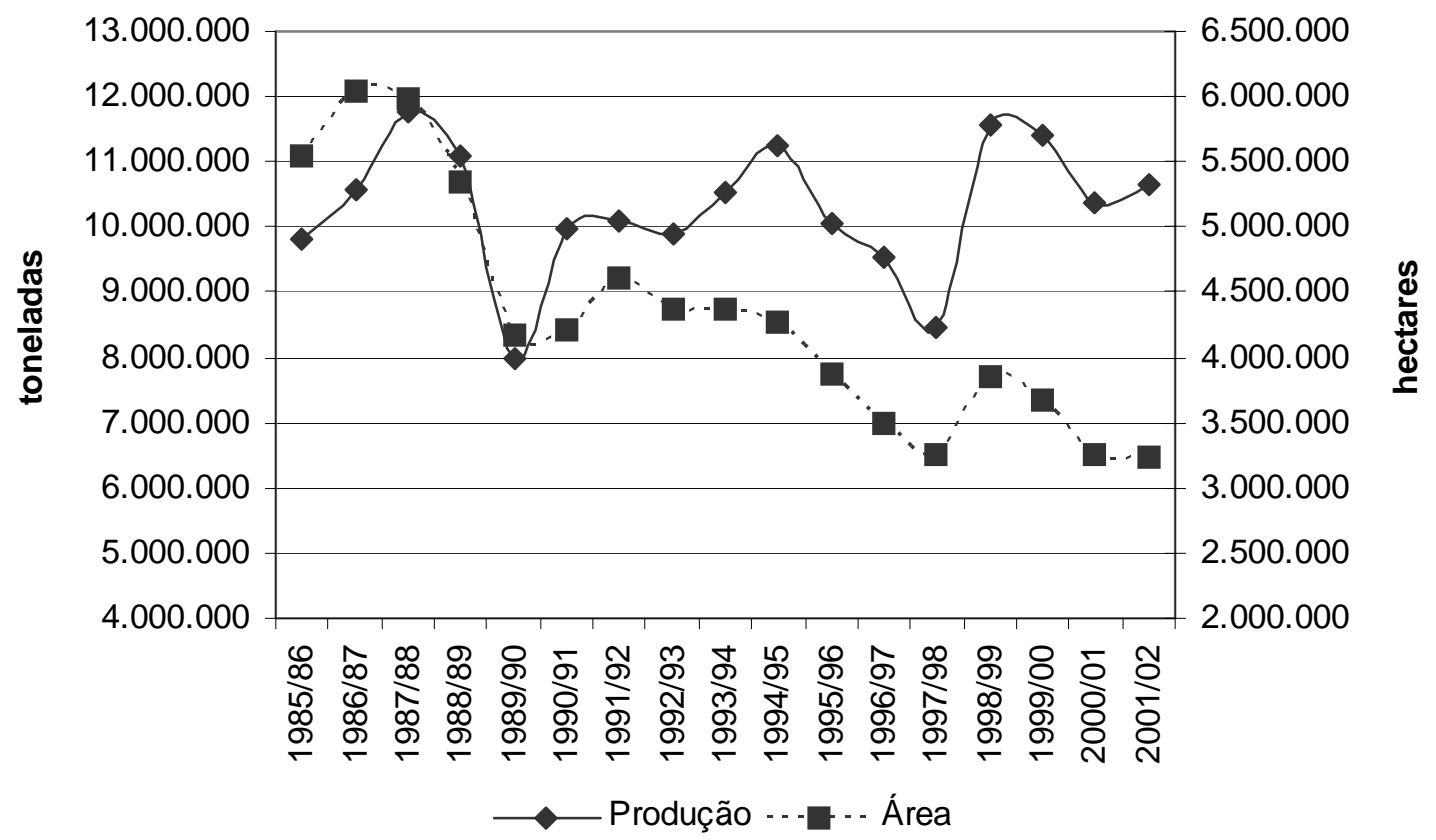

Figura 1 - Produção e área colhida de arroz no Brasil.

Fonte: Conab (2002) 
Tabela 3. Importações brasileiras de arroz proveniente do Mercosul e total importado pelo país (em toneladas).

\begin{tabular}{ccccccc}
\hline Países & 1997 & 1998 & 1999 & 2000 & 2001 & 2002 \\
\hline Argentina & 400.187 .432 & 577.516 .969 & 565.884 .994 & 283.028 .485 & 259.315 .245 & 194.084 .943 \\
Uruguai & 551.724 .264 & 606.515 .360 & 516.518 .990 & 522.088 .130 & 624.886 .603 & 518.442 .220 \\
Paraguai & 10.976 .820 & 1.680 .640 & 1.685 .000 & 24.633 .350 & 15.602 .000 & 10.395 .250 \\
Total & 1.011 .584 .907 & 1.704 .328 .111 & 1.345 .146 .165 & 859.299 .679 & 901.213 .377 & 730.478 .106 \\
\hline
\end{tabular}

Fonte: Brasil (2003)

Os dados da Tabela 3 referem-se à soma das categorias arroz com casca, sem casca e branqueado, cujos códigos na nomenclatura comum do Mercosul são: 1006.00.00 a 1006.19.99, 1006.20.00 a 1006.20.20 e 1006.30.11 a 1006.30.29, respectivamente. As categorias arroz sem casca e branqueado foram transformadas em casca, de acordo com Gameiro et al. (2003). Verifica-se que em 1997 os países do Mercosul foram responsáveis por 95\% do volume total importado pelo Brasil. Em 1998 ocorreu a menor participação dos países do bloco no mercado brasileiro, apenas 70\%. Apesar dessa grande queda, percebe-se, posteriormente, a recuperação da representatividade do Mercosul no mercado brasileiro de arroz, sendo esses países, em 1999, responsáveis por 80\% das importações e em 2000, por aproximadamente 97\%. O ápice ocorreu em 2001, quando o Mercosul respondeu por 99,8\% do total importado, cabendo aos Estados Unidos, Itália, Tailândia, França, Japão e Dinamarca completarem o volume total de importação brasileira. O cenário não se modificou em 2002, e mais uma vez o Mercosul foi responsável pela maior parte das importações brasileiras de $\operatorname{arroz}(99 \%)$.

Analisando a série de dados de produção de arroz da Figura 1, percebe-se uma certa instabilidade, havendo uma brusca queda que se iniciou no ano agrícola 1988/89 e uma redução menos acentuada que se iniciou na safra agrícola 1995/96. O crescimento da produção brasileira no período considerado foi de 8,5\%, com uma produção média de 10,295 milhões de toneladas. Ao analisar a evolução da área colhida de arroz no Brasil, verifica-se uma tendência de redução, até atingir o patamar de 3,4 
milhões de hectares em 2000/01. A escassez de novas áreas a serem exploradas, as leis que protegem o meio ambiente e as terras impróprias para o cultivo são fatores determinantes dessa estagnação. As instituições que pesquisam o arroz de terras altas objetivam a inserção desse cereal no Centro-Oeste brasileiro em dinâmica de cultura com outras atividades agropecuárias.

Através dos dados apresentados na Figura 1, pode-se concluir que ocorreu aumento da produtividade do arroz no Brasil ao longo do tempo, passando de 1.770 kg/ha na safra 1985/86 para 3.299 kg/ha na safra 2001/02, crescimento à taxa de $4 \%$ ao ano.

O arroz é produzido em todo o território nacional, mas a produção está concentrada principalmente na região Sul e Centro-Oeste. A região Sul é responsável por aproximadamente $62 \%$ da produção nacional, tendo destaque o Rio Grande do Sul, responsável por $83 \%$ da produção dessa região e por mais da metade da produção nacional (51\%). O Estado de Santa Catarina, terceiro maior produtor do país, é, conforme já mencionado, o que detém a maior produtividade, com 6.600 kg por hectare. A região Centro-Oeste responde por 15\% da produção brasileira, destacando-se o Estado do Mato Grosso, segundo maior produtor nacional, com $74 \%$ da produção regional e 11\% da produção do país (Conab, 2002) (Tabela 4).

A área ocupada pela cultura do arroz no Sul do país representa 37\% da área nacional, sendo que o Rio Grande do Sul possui a maior parte, 30\% da área brasileira ocupada com a orizicultura em 2002 e 82\% da área da região Sul. A região Centro-Oeste é a terceira colocada em termos de área, perdendo para o Nordeste; ela abrange $18 \%$ da área nacional de arroz, enquanto o Nordeste é responsável por 23\%. O Estado do Mato Grosso ocupa apenas a terceira posição quanto à área cultivada, representando $13 \%$ da área nacional, perdendo para o Maranhão, que tem 15\% da área nacional cultivada com arroz e para o Rio Grande do Sul (Conab, 2002). Visualiza-se na Tabela 5 a área nacional cultivada com arroz. 
Tabela 4. Produção brasileira de arroz da safra 1985/86 a 2001/02, em mil toneladas.

\begin{tabular}{|c|c|c|c|c|c|c|c|c|c|c|c|c|c|c|c|c|c|}
\hline & $\begin{array}{c}1985 / \\
86\end{array}$ & $\begin{array}{c}1986 / \\
87\end{array}$ & $\begin{array}{c}1987 / \\
88\end{array}$ & $\begin{array}{c}1988 / \\
89\end{array}$ & $\begin{array}{c}1989 / \\
90\end{array}$ & $\begin{array}{c}1990 / \\
91\end{array}$ & $\begin{array}{c}1991 / \\
92\end{array}$ & $\begin{array}{c}1992 / \\
93\end{array}$ & $\begin{array}{c}1993 / \\
94\end{array}$ & $\begin{array}{c}1994 / \\
95\end{array}$ & $\begin{array}{c}1995 / \\
96\end{array}$ & $\begin{array}{c}1996 / \\
97\end{array}$ & $\begin{array}{c}1997 / \\
98\end{array}$ & $\begin{array}{c}1998 / \\
99\end{array}$ & $\begin{array}{c}1999 / \\
00\end{array}$ & $\begin{array}{c}2000 / \\
01\end{array}$ & $\begin{array}{c}2001 / \\
02\end{array}$ \\
\hline Norte & 377,56 & 381,5 & $1.117,7$ & $1.172,1$ & 605,6 & 721,4 & 744,2 & 761,3 & 977,3 & $1.109,0$ & 996,0 & 985,2 & 968,7 & $1.109,8$ & $1.150,9$ & $1.094,5$ & $1.119,5$ \\
\hline RO & 170,1 & 171,4 & 221,6 & 248,9 & 142,7 & 131,1 & 180,8 & 161,3 & 248,7 & 257,8 & 257,6 & 246,8 & 188,3 & 154,5 & 189,6 & 168,4 & 131,5 \\
\hline AC & 38,0 & 40,9 & 42,8 & 42,9 & 43,5 & 45,7 & 46,3 & 46,3 & 48,8 & 50,2 & 50,2 & 50,2 & 23,6 & 27,8 & 32,4 & 36,0 & 31,3 \\
\hline AM & 4,1 & 3,6 & 2,0 & 5,0 & 2,3 & 4,8 & 4,2 & 4,2 & 2,5 & 6,4 & 3,3 & 3,3 & 30,6 & 30,6 & 30,8 & 33,3 & 31,9 \\
\hline RR & 11,9 & 10,4 & 8,8 & 17,4 & 10,8 & 16,0 & 28,4 & 28,4 & 35,6 & 49,6 & 49,6 & 49,6 & 49,6 & 50,8 & 51,2 & 59,8 & 71,5 \\
\hline PA & 152,9 & 154,8 & 184,6 & 209,5 & 146,8 & 213,8 & 207,1 & 207,1 & 250,2 & 331,2 & 292,9 & 292,9 & 327,6 & 417,8 & 453,9 & 431,7 & 480,2 \\
\hline AP & 0,55 & 0,44 & 0,57 & 1,13 & 0,34 & 0,33 & 0,28 & 0,26 & 0,3 & 0,7 & 0,5 & 0,5 & 0,5 & 0,8 & 1,0 & 1,9 & 1,9 \\
\hline TO & - & - & 657,3 & 647,3 & 259,2 & 309,7 & 277,1 & 313,7 & 391,2 & 413,1 & 341,9 & 341,9 & 348,5 & 427,5 & 392,0 & 363,4 & 371,2 \\
\hline Nordeste & $1.735,7$ & $1.088,7$ & $2.017,6$ & $1.666,2$ & 839,1 & $1.683,4$ & 884,1 & 817,5 & $1.628,7$ & $1.709,4$ & $1.684,8$ & $1.502,2$ & 933,1 & $1.151,5$ & $1.337,2$ & $1.014,5$ & 966,4 \\
\hline MA & $1.040,4$ & 685,6 & $1.229,3$ & $1.007,6$ & 414,2 & 985,6 & 416,1 & 534,0 & 837,9 & 926,1 & 926,1 & 808,3 & 587,1 & 621,0 & 717,3 & 661,1 & 624,0 \\
\hline PI & 328,0 & 138,9 & 407,7 & 311,1 & 137,9 & 314,8 & 167,2 & 97,3 & 398,9 & 399,3 & 375,5 & 356,7 & 92,9 & 195,9 & 251,8 & 180,6 & 85,8 \\
\hline CE & 141,8 & 125,3 & 160,6 & 124,7 & 128,1 & 164,3 & 128,1 & 56,7 & 188,6 & 200,0 & 211,1 & 157,5 & 86,6 & 155,0 & 169,0 & 48,2 & 98,7 \\
\hline RN & 11,3 & 6,0 & 7,7 & 8,0 & 3,8 & 6,0 & 3,4 & 0,73 & 3,8 & 4,6 & 3,6 & 1,4 & 0,8 & 1,4 & 1,7 & 0,9 & 5,2 \\
\hline PB & 22,4 & 19,7 & 21,7 & 27,8 & 20,4 & 33,6 & 15,7 & 0,7 & 19,4 & 18,6 & 23,2 & 17,7 & 2,6 & 8,0 & 14,8 & 0,6 & 10,9 \\
\hline PE & 29,8 & 26,3 & 27,0 & 33,9 & 29,4 & 26,6 & 25,2 & 17,5 & 26,4 & 19,7 & 19,0 & 19,3 & 16,1 & 18,9 & 19,6 & 18,5 & 21,1 \\
\hline AL & 25,7 & 21,8 & 25,2 & 29,1 & 29,4 & 28,3 & 29,8 & 28,4 & 44,1 & 28,5 & 33,5 & 32,3 & 29,6 & 32,3 & 32,3 & 35,1 & 38,6 \\
\hline SE & 31,7 & 21,5 & 39,3 & 39,7 & 39,1 & 32,7 & 38,4 & 30,3 & 38,9 & 15,1 & 29,0 & 34,0 & 35,8 & 35,7 & 37,5 & 37,5 & 43,9 \\
\hline BA & 104,6 & 43,6 & 99,1 & 84,3 & 36,8 & 91,5 & 60,2 & 51,9 & 70,7 & 97,5 & 63,8 & 75,0 & 81,6 & 83,3 & 93,2 & 32,0 & 38,2 \\
\hline Sudeste & $1.626,2$ & $1.674,3$ & $1.600,1$ & $1.483,2$ & $1.058,7$ & $1.369,7$ & $1.234,3$ & $1.229,5$ & $1.063,2$ & 947,5 & 811,2 & 729,8 & 508,6 & 485,4 & 438,0 & 325,2 & 343,0 \\
\hline MG & 888,0 & 910,5 & 901,6 & 791,0 & 584,8 & 843,6 & 788,3 & 770,9 & 642,2 & 605,7 & 533,5 & 480,1 & 342,1 & 324,5 & 290,7 & 192,1 & 210,5 \\
\hline ES & 118,2 & 110,2 & 108,8 & 112,5 & 103,3 & 107,6 & 107,6 & 126,2 & 85,3 & 68,1 & 65,1 & 53,6 & 28,9 & 20,1 & 18,6 & 20,2 & 13,4 \\
\hline RJ & 125,4 & 96,7 & 97,0 & 103,5 & 44,0 & 55,0 & 52,5 & 75,1 & 63,8 & 51,5 & 36,0 & 27,3 & 16,1 & 14,7 & 14,5 & 11,8 & 8,3 \\
\hline SP & 494,6 & 556,9 & 492,7 & 476,2 & 326,6 & 363,5 & 285,9 & 257,3 & 271,9 & 222,2 & 176,6 & 168,8 & 121,5 & 126,1 & 114,2 & 101,1 & 110,8 \\
\hline Sul & $3.759,7$ & $4.403,8$ & $4.852,4$ & $4.964,6$ & $4.498,8$ & $4.935,1$ & $5.498,6$ & $5.750,9$ & $5.179,2$ & $6.013,1$ & $5.135,3$ & $5.129,5$ & $4.581,6$ & $6.693,3$ & $6.068,8$ & $6.260,8$ & $6.576,6$ \\
\hline PR & 206,0 & 342,8 & 316,7 & 295,7 & 253,5 & 163,7 & 216,7 & 221,5 & 243,6 & 221,6 & 192,8 & 178,6 & 166,8 & 196,8 & 176,9 & 178,6 & 182,5 \\
\hline SC & 424,7 & 507,1 & 552,3 & 559,1 & 565,4 & 687,8 & 714,4 & 643,0 & 713,8 & 721,5 & 732,2 & 790,5 & 805,7 & 881,4 & 804,0 & 891,7 & 929,3 \\
\hline RS & $3.129,0$ & $3.553,9$ & $3.983,4$ & $4.109,8$ & $3.679,9$ & $4.083,6$ & $4.567,5$ & $4.886,4$ & $4.221,8$ & $5.070,0$ & $4.210,3$ & $4.160,4$ & $3.609,1$ & $5.615,1$ & $5.087,9$ & $5.190,5$ & $5.464,8$ \\
\hline Centro-Oeste & $2.320,8$ & $3.022,4$ & $2.160,2$ & $1.797,5$ & 963,8 & $1.281,9$ & $1.741,2$ & $1.343,1$ & $1.675,0$ & $1.459,0$ & $1.410,6$ & $1.177,8$ & $1.470,9$ & $2.142,2$ & $2.428,2$ & $1.691,0$ & $1.650,1$ \\
\hline MS & 279,4 & 509,0 & 372,3 & 283,6 & 168,3 & 231,8 & 232,2 & 247,3 & 251,2 & 235,8 & 254,3 & 236,7 & 204,0 & 259,6 & 251,4 & 216,1 & 218,1 \\
\hline MT & 750,0 & 951,6 & 895,9 & 881,6 & 424,9 & 499,2 & 876,9 & 641,4 & 909,0 & 760,0 & 842,4 & 690,9 & $1.018,6$ & $1.503,3$ & $1.890,8$ & $1.267,4$ & $1.215,7$ \\
\hline GO & $1.281,6$ & $1.548,8$ & 882,2 & 627,4 & 366,8 & 544,0 & 624,2 & 450,8 & 511,7 & 461,4 & 313,0 & 249,7 & 247,7 & 375,6 & 284,1 & 207,3 & 216,0 \\
\hline DF & 9,8 & 13,0 & 9,8 & 4,9 & 3,8 & 6,9 & 7,9 & 3,6 & 3,1 & 1,8 & 0,9 & 0,5 & 0,6 & 3,7 & 1,9 & 0,2 & 0,3 \\
\hline Brasil & $9.820,0$ & $10.570,8$ & $11.748,0$ & $11.083,6$ & $7.966,0$ & $9.991,5$ & $10.102,4$ & $9.902,3$ & $10.523,4$ & $11.238,0$ & $10.037,9$ & $9.524,5$ & $8.462,9$ & $11.582,2$ & $11.423,1$ & $10.386,0$ & $10.655,6$ \\
\hline
\end{tabular}

Fonte: Conab (2002) 
Tabela 5. Área colhida de arroz no Brasil da safra 1985/86 a 2001/02, em mil hectares.

\begin{tabular}{|c|c|c|c|c|c|c|c|c|c|c|c|c|c|c|c|c|c|}
\hline & $\begin{array}{c}1985 / \\
86 \\
\end{array}$ & $\begin{array}{c}1986 / \\
87 \\
\end{array}$ & $\begin{array}{c}19871 \\
88 \\
\end{array}$ & $\begin{array}{c}1988 / \\
89 \\
\end{array}$ & $\begin{array}{c}1989 / \\
90\end{array}$ & $\begin{array}{c}1990 / \\
91 \\
\end{array}$ & $\begin{array}{c}1991 / \\
92 \\
\end{array}$ & $\begin{array}{c}1992 / \\
93 \\
\end{array}$ & $\begin{array}{c}1993 / \\
94 \\
\end{array}$ & $\begin{array}{c}1994 / \\
95 \\
\end{array}$ & $\begin{array}{c}1995 / \\
96 \\
\end{array}$ & $\begin{array}{c}1996 / \\
97 \\
\end{array}$ & $\begin{array}{c}1997 / \\
98 \\
\end{array}$ & $\begin{array}{c}1998 / \\
99\end{array}$ & $\begin{array}{c}1999 / \\
00\end{array}$ & $\begin{array}{c}2000 / \\
01 \\
\end{array}$ & $\begin{array}{c}2001 / \\
02 \\
\end{array}$ \\
\hline Norte & 272,9 & 249,1 & 776,3 & 742,2 & 460,3 & 438,5 & 471,8 & 467,3 & 542,4 & 604,0 & 532,5 & 529,6 & $575, .0$ & 621,1 & 615,6 & 553,4 & 541,9 \\
\hline RO & 113,4 & 102,0 & 133,5 & 147,3 & 87,0 & 79,0 & 113,0 & 97,2 & 150,0 & 149,0 & 143,9 & 141,0 & 111,4 & 103,0 & 94,8 & 92,0 & 70,0 \\
\hline AC & 27,2 & 29,2 & 28,5 & 30,1 & 30,2 & 29,7 & 29,7 & 29,7 & 32,0 & 34,6 & 34,6 & 34,6 & 18,9 & 21,3 & 25,8 & 26,5 & 22,5 \\
\hline AM & 4,3 & 3,0 & 2,0 & 4,9 & 2,1 & 4,0 & 3,5 & 3,5 & 1,9 & 5,1 & 2,6 & 2,6 & 16,7 & 16,7 & 16,8 & 17,5 & 16,8 \\
\hline $\mathrm{RR}$ & 7,9 & 8,7 & 4,3 & 7,9 & 6,0 & 4,0 & 9,9 & 9,9 & 10,8 & 15,7 & 15,7 & 15,7 & 15,7 & 15,7 & 15,5 & 15,5 & 15,5 \\
\hline PA & 119,0 & 105,6 & 164,8 & 167,6 & 125,5 & 158,4 & 152,3 & 152,3 & 178,7 & 230,0 & 203,4 & 203,4 & 280,0 & 303,0 & 313,0 & 264,5 & 269,8 \\
\hline AP & 1,1 & 0,6 & 0,6 & 1,4 & 0,5 & 0,4 & 0,4 & 0,4 & 0,4 & 1,0 & 0,8 & 0,8 & 0,8 & 1,0 & 1,2 & 2,3 & 2,3 \\
\hline TO & - & - & 442,6 & 383,0 & 209,0 & 163,0 & 163,0 & 174,3 & 168,6 & 168,6 & 131,5 & 131,5 & 131,5 & 160,4 & 148,5 & 135,1 & 145,0 \\
\hline Nordeste & $1.310,9$ & $1.338,7$ & $1.401,3$ & $1.383,9$ & $1.069,5$ & $1.196,9$ & $1.183,4$ & $1.050,8$ & $1.097,4$ & $1.113,6$ & $1.081,9$ & $1.010,1$ & 712,4 & 757,5 & 800,0 & 729,6 & 735,3 \\
\hline MA & 867,0 & 919,0 & 932,9 & 933,0 & 690,4 & 770,0 & 730,0 & 600,0 & 630,0 & 661,5 & 661,5 & 621,8 & 434,9 & 443,6 & 478,2 & 459,1 & 480,0 \\
\hline $\mathrm{PI}$ & $250, .0$ & 217,0 & 263,0 & 255,0 & 226,0 & 244,0 & 254,9 & 270,2 & 284,9 & 281,2 & 250,3 & 237,8 & 145,1 & 160,0 & 172,8 & 164,2 & 156,0 \\
\hline CE & 60,7 & 70,4 & 74,0 & 67,4 & 61,0 & 75,0 & 76,5 & 78,7 & 82,0 & 77,5 & 81,7 & 65,4 & 50,4 & 53,5 & 60,1 & 45,7 & 42,0 \\
\hline RN & 9,0 & 5,0 & 5,5 & 5,7 & 3,1 & 4,3 & 4,2 & 0,5 & 2,5 & 2,7 & 2,5 & 1,7 & 1,0 & 1,0 & 1,0 & 1,1 & 2,0 \\
\hline PB & 12,0 & 14,0 & 15,3 & 15,0 & 14,6 & 16,0 & 15,7 & 2,1 & 9,7 & 13,3 & 12,0 & 10,6 & 8,0 & 8,1 & 9,0 & 5,9 & 7,5 \\
\hline PE & 8,6 & 9,7 & 7,7 & 9,2 & 8,4 & 7,0 & 7,0 & 7,0 & 7,0 & 5,0 & 4,5 & 4,6 & 3,9 & 4,5 & 4,7 & 3,6 & 3,9 \\
\hline AL & 8,8 & 7,8 & 8,2 & 9,4 & 8,5 & 8,2 & 8,5 & 8,1 & 12,0 & 9,5 & 9,5 & 8,5 & 7,8 & 8,5 & 8,5 & 6,5 & 7,0 \\
\hline SE & 11,1 & 8,6 & 12,1 & 12,6 & 11,5 & 11,4 & 11,4 & 9,0 & 9,8 & 4,5 & 9,7 & 9,7 & 10,3 & 8,9 & 10,2 & 10,2 & 10,2 \\
\hline BA & 83,7 & 87,2 & 82,6 & 76,6 & 46,0 & 61,0 & 75,2 & 75,2 & 59,5 & 58,4 & 50,2 & 50,0 & 51,0 & 69,4 & 55,5 & 33,3 & 26,7 \\
\hline Sudeste & 947,2 & 976,0 & 897,8 & 811,2 & 720,7 & 702,0 & 694,1 & 654,6 & 576,2 & 544,0 & 452,0 & 374,0 & 269,0 & 264,6 & 208,7 & 171,4 & 145,8 \\
\hline MG & 555,0 & 599,0 & 560,0 & 488,3 & 430,0 & 461,0 & 461,0 & 438,0 & 372,3 & 364,9 & 310,2 & 254,4 & 181,0 & 180,3 & 135,2 & 108,2 & 97,9 \\
\hline ES & 39,2 & 39,8 & 35,8 & 36,9 & 36,9 & 36,0 & 36,0 & 32,0 & 26,7 & 26,2 & 21,0 & 17,2 & 9,8 & 7,8 & 6,6 & 6,5 & 4,6 \\
\hline RJ & 38,0 & 31,2 & 31,0 & 30,0 & 23,8 & 15,7 & 15,0 & 20,7 & 18,2 & 14,9 & 10,4 & 8,6 & 5,0 & 5,5 & 5,0 & 3,5 & 2,7 \\
\hline SP & 315,0 & 306,0 & 271,0 & 256,0 & 230,0 & 189,3 & 182,1 & 163,9 & 159,0 & 138,0 & 110,4 & 93,8 & 73,2 & 71,0 & 61,9 & 53,2 & 40,6 \\
\hline Sul & $1.033,5$ & $1.141,5$ & $1.156,7$ & $1.145,0$ & $1.054,2$ & $1.098,9$ & $1.154,5$ & $1.233,4$ & $1.233,8$ & $1.239,3$ & $1.078,7$ & $1.025,7$ & $1.075,2$ & $1.194,1$ & $1.156,6$ & $1.165,0$ & $1.201,5$ \\
\hline PR & 140,0 & 202,9 & 188,6 & 163,6 & 151,0 & 121,3 & 127,5 & 121,4 & 105,3 & 110,8 & 96,4 & 91,6 & 83,4 & 82,0 & 80,4 & 78,0 & 78,0 \\
\hline SC & 148,5 & 157,0 & 160,1 & 155,3 & 152,2 & 147,6 & 152,0 & 152,0 & 153,5 & 153,5 & 153,5 & 155,0 & 142,6 & 127,0 & 134,0 & 136,7 & 140,8 \\
\hline RS & 745,0 & 781,6 & 808,0 & 826,1 & 751,0 & 830,0 & 875,0 & 960,0 & 975,0 & 975,0 & 828,8 & 779,1 & 849,2 & 985,1 & 942,2 & 950,3 & 982,7 \\
\hline Centro-Oeste & $1.982,5$ & $2.332,0$ & $1.741,7$ & $1.267,5$ & 874,3 & 776,8 & $1.103,1$ & 971,0 & 924,9 & 767,0 & 718,5 & 555,0 & 617,4 & $1.007,9$ & 896,7 & 630,9 & 605,2 \\
\hline MS & 302,0 & 377,0 & 297,8 & 166,8 & 127,0 & 112,0 & 135,0 & 116,1 & 106,0 & 94,3 & 87,7 & 78,9 & 60,0 & 70,0 & 73,5 & 53,7 & 51,0 \\
\hline MT & 600,0 & 732,0 & 746,8 & 612,2 & 376,0 & 320,0 & 555,0 & 505,1 & 505,0 & 400,0 & 432,0 & 337,0 & 428,0 & 730,0 & 675,3 & 459,2 & 440,3 \\
\hline GO & $1.068,0$ & $1.210,0$ & 689,4 & 482,6 & 366,8 & 340,0 & 408,0 & 346,8 & 312,0 & 271,4 & 198,1 & 138,7 & 129,0 & 206,4 & 147,2 & 117,8 & 113,7 \\
\hline DF & 12,5 & 13,0 & 7,7 & 5,9 & 4,5 & 4,8 & 5,1 & 3,0 & 1,9 & 1,3 & 0,7 & 0,4 & 0,4 & 1,5 & 0,7 & 0,2 & 0,2 \\
\hline Brasil & $5.547,0$ & $6.037,4$ & $5.973,8$ & $5.349,8$ & $4.179,0$ & $4.213,1$ & $4.606,9$ & $4.377,0$ & $4.374,7$ & $4.267,9$ & $3.863,6$ & $3.494,4$ & $3.249,0$ & $3.845,2$ & $3.677,6$ & $3.250,3$ & $3.229,7$ \\
\hline
\end{tabular}

Fonte: Conab (2002) 
A produção de arroz no Rio Grande do Sul cresceu $75 \%$ entre as safras 1985/86 e 2001/02, devido ao aumento da área e da produtividade, ambos de 32\%. Considerando o período em análise, esse estado sempre foi o maior produtor de arroz, mas somente a partir do ano agrícola de 1989/90 foi o responsável pela maior área plantada. Esse estado também detinha a maior produtividade, no entanto, hoje a liderança é de Santa Catarina.

O Estado do Mato Grosso sempre esteve entre os quatro maiores produtores brasileiros de arroz, sendo que sua produção aumentou $62 \%$ no período analisado, enquanto a área plantada decresceu 27\%, passando de 600 mil ha em 1985/86 para 440,3 mil ha em 2001/02, após atingir um pico de 730 mil ha em 1998/99. Apesar da produtividade ainda estar aquém do potencial das variedades de terras altas cultivadas no Mato Grosso, esta aumentou 121\% no período, passando de 1.250 kg/ha em 1985/86 para os atuais $2.761 \mathrm{~kg} / \mathrm{ha}$.

Destacam-se dois principais tipos de cultivo de arroz: irrigado e de terras altas, conforme citado anteriormente. O termo "terras altas" vem sendo utilizado pela Empresa Brasileira de Pesquisa Agropecuária - Embrapa em substituição ao "arroz de sequeiro", com o intuito de resgatar a credibilidade do arroz neste sistema, abalada em função da orizicultura ser usada como cultura desbravadora do cerrado (Ferreira \& Yokoyama, 1999).

Na região Sul, principal fornecedora do cereal para o país, planta-se arroz irrigado, utilizando modernas técnicas de produção, desde o uso racional da água até a adoção do semeio de arroz pré-germinado. Com um panorama de produção mais organizado e profissional que o do Centro-Oeste, o Sul é responsável atualmente por cerca de $60 \%$ da produção nacional. Pode-se associar os dois tipos de sistema de produção de arroz às localidades em que são produzidos: na região Sul predomina o irrigado e no restante do país, o arroz de terras altas. Essa distinção grosseira fornece uma aproximação razoável, visto que as áreas em que se cultiva arroz irrigado fora da região Sul são bastante pequenas (Figura 2). 


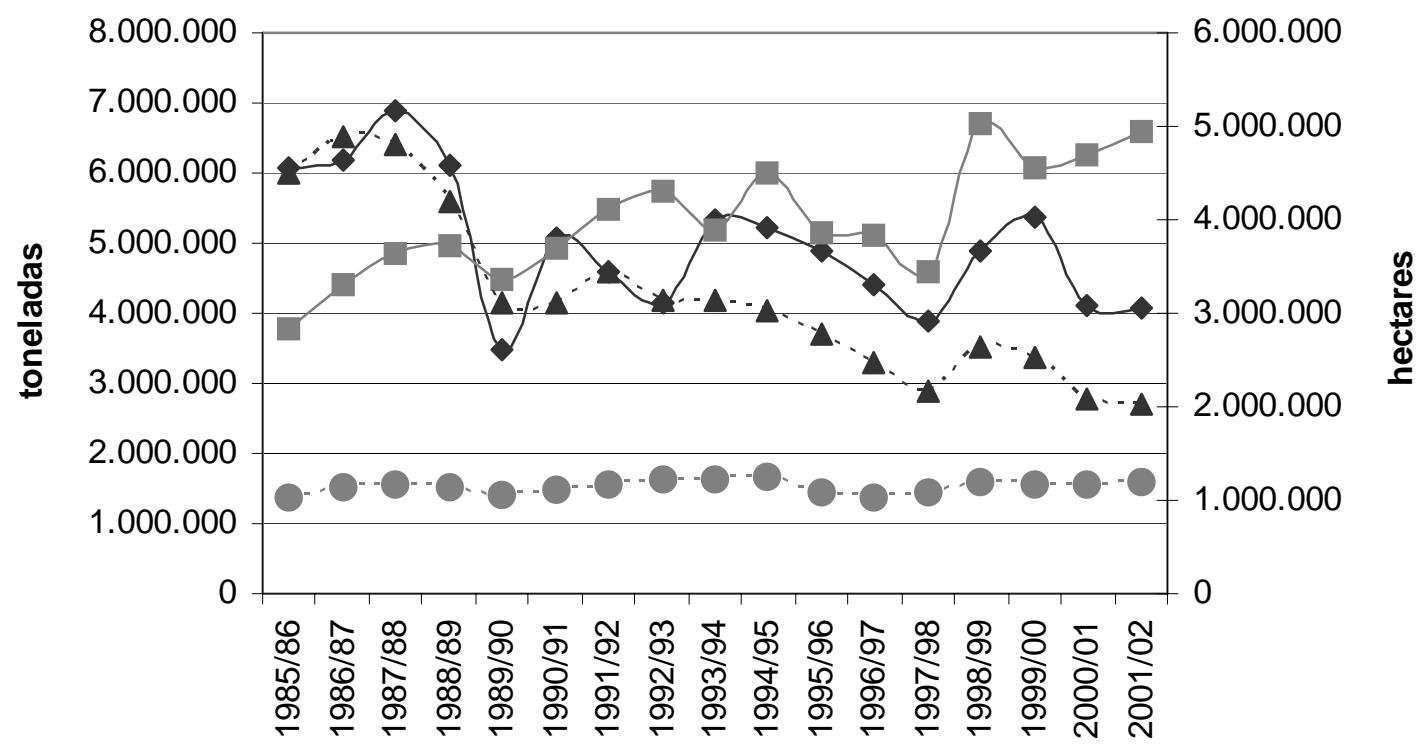

$\longrightarrow$ Prod. terras altas —— Prod. irrigado ... - . . Área terras altas ... . . Área irrigado

Figura 2 - Produção e área de arroz de terras altas e irrigado.

Fonte: Conab (2002)

No Rio Grande do Sul encontram-se alguns entraves para a expansão da atividade orizícola, pois há dificuldade de se incorporar novas áreas para o cultivo, dada a restrição dos recursos hídricos e a existência de áreas impróprias. O sistema de cultivo irrigado tem o custo de produção mais elevado que o sistema de terras altas. Insumos como a água, maquinário de irrigação, de drenagem, preparo do solo, sistematização da área, construção de canais e taipas, entre outros, oneram os custos da produção gaúcha, além de o valor da terra no Sul ser mais alto (Yokoyama, 2002). Um fator que deve ser levado em consideração é que esses insumos são aproveitados somente no arroz. No Centro-Oeste, os custos de produção são diluídos em outras culturas, como a soja, por exemplo. No estudo de competitividade realizado por Villar et al. (2003), enfocando basicamente os custos de produção de arroz nos dois sistemas, representados por fazendas nos municípios de Santa Vitória do Palmar-RS e Sinop-MT, verificou-se que o cultivo irrigado é mais "caro" que o cultivo de terras altas. Nos itens considerados pelos autores, somente o valor do fertilizante no sistema irrigado é inferior ao do de terras 
altas, devido a diferenças no custo de transporte. Segundo esses autores, o custo do arroz por tonelada no Rio Grande do Sul é de US\$ 100,02, enquanto no Mato Grosso é US\$ 93,58. Outra característica observada pelos autores foi a melhor gestão da empresa agrícola no Rio Grande do Sul, atuando de forma mais coordenada, predominantemente sob a forma de gestão familiar, enquanto no Mato Grosso a gestão é realizada por profissionais contratados.

Utilizando a mesma distinção entre arroz de terras altas e irrigado na formulação da Figura 2, tem-se que a produtividade do arroz de terras altas e irrigado cresceram à taxa de 2,95\% a.a. e 2,12\% a.a., respectivamente. $\mathrm{O}$ arroz de terras altas, mesmo crescendo anualmente a taxas maiores do que o arroz irrigado, tem produtividade inferior, correspondendo a metade da produtividade do arroz irrigado (Figura 3).

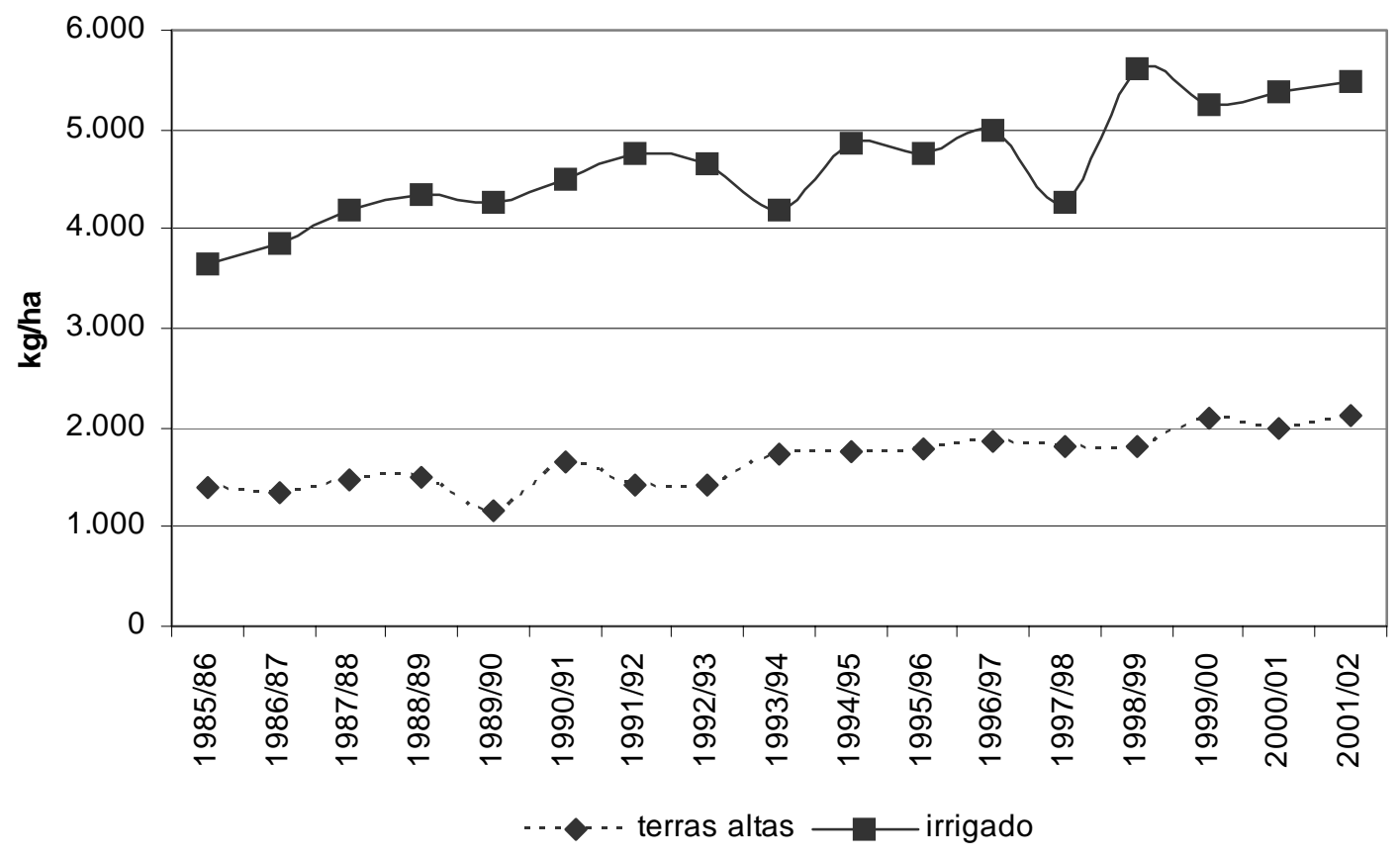

Figura 3 - Produtividade do arroz de terras altas e do irrigado.

Fonte: Conab (2002)

O crescimento da produtividade do arroz de terras altas poderia ser maior devido ao potencial produtivo das variedades mais recentes, porém o cultivo desse arroz 
ocorre em um padrão tecnológico inferior ao empregado para o arroz irrigado. A produtividade do arroz em ambos os sistemas cresceu cerca de 50\% ao longo do período. Apresenta-se, na Tabela 6, a relação de algumas variedades lançadas na década de 1990 e que estão sendo utilizadas no Mato Grosso.

Tabela 6. Variedades de arroz de terras altas lançadas na década de 1990.

\begin{tabular}{cccc}
\hline Variedades & Lançamento & $\begin{array}{c}\text { Produtividade } \\
(\mathrm{kg} / \mathrm{ha})\end{array}$ & $\begin{array}{c}\text { Estados } \\
\text { recomendados }\end{array}$ \\
\hline BRS Primavera & 1994 & 3.153 & GO, MA, MT, PI \\
Cirad 141 & & $3.400^{*}$ & GO, DF, AC, MT, RO, AM, MS, TO \\
Maravilha & 1996 & 3.015 & GO, DF, AC, MT, RO, AM, MS, TO \\
BRS Bonança & 2000 & 3.210 & GO, MT, MS, TO, BA, PI, MA \\
Sucupira & & $3.550^{*}$ & GO, MT, MS, TO, BA, PI, MA \\
Carajás & 1994 & 2.801 & GO, DF, MT, MS, TO, MA, PI, BA \\
Caiapó & 1992 & 2.998 & GO, MT, MS, TO, MG, MA, PI, BA \\
BRS Talento & 2001 & 3.736 & MT, GO, TO, RO, MA, PI \\
\hline
\end{tabular}

Fonte: Embrapa Arroz e Feijão (2003); Sant’Ana et al. (2000)

* Valores obtidos nas entrevistas

A maior parte da produção gaúcha e brasileira de arroz se dá em propriedades entre 200 e 500 ha. Já a produção mato-grossense, em sua maioria, se dá em propriedades cuja extensão territorial é de 2 mil a 5 mil ha (IBGE, 2003c).

A produção no Centro-Oeste apresenta um fator cultural que explica em parte a situação da orizicultura de terras altas. O cultivo do arroz de terras altas sempre esteve ligado ao processo de abertura de área para posterior cultivo de soja ou atividade pecuária. Praticava-se, também, uma agricultura itinerante, associada normalmente à subsistência, sendo mais observada no Nordeste brasileiro. Tem-se ainda no CentroOeste, o plantio comercial em áreas específicas para arroz. Contudo, esse tipo de cultivo apresenta maior importância na região Sul (Steinmetz, 1983). 
Apesar de sua relevância, o arroz de terras altas passou um longo período relegado ao segundo plano, o que decorre parcialmente do seu passado, quando a exploração ocorria em um contexto caracterizado por baixo aporte tecnológico, com baixa produtividade e baixa qualidade da matéria-prima. Era uma exploração agrícola baseada somente na "domesticação" da terra, sendo mais considerada como um instrumento de abertura do cerrado do que como uma atividade comercial que possibilitava boa rentabilidade (Ferreira et al., 2002a). O arroz de terras altas também tinha o seu uso ligado à recuperação de áreas degradadas. Segundo Portugal (1996), o arroz, juntamente com o feijão, foram acusados de retardatários do processo de modernização da agricultura brasileira.

O Mato Grosso, ao contrário da maioria dos estados, apresentou nos últimos oito anos um aumento da área de arroz da ordem de 10\%. A principal explicação para esse comportamento é o processo de expansão da fronteira agrícola, utilizando o arroz como cultura pioneira, para em seguida ceder espaço para a soja ou atividade pecuária (Villar \& Ferreira, 2002). Esse fenômeno também foi observado por Igreja et al. (1995) para os estados de Goiás e Tocantins.

Portugal (1998) afirma que o agronegócio nacional tem sido demasiadamente afetado pelas transformações econômicas, políticas e sociais, que vêm mudando sobremaneira o Brasil. A abertura do mercado foi, sem dúvida, um marco na história brasileira e estimulou as atividades agrícolas e suas respectivas cadeias produtivas a buscarem maior competitividade, fazendo com que a tecnologia e a gestão empresarial se tornassem fatores diferenciadores. Por outro lado, aumentou a preocupação da sociedade com a sustentabilidade ambiental. Segundo Villar et al. (2003), o Mato Grosso ainda é considerado uma região de fronteira agrícola, onde o arroz exerce importante papel agronômico como cultura que se adapta a áreas "sujas". Quirino (1998) considera fundamental para o sistema nacional de pesquisa agropecuária a modelagem de agroecossistemas e a análise socioeconômica dos impactos positivos e negativos resultantes da adoção de novas tecnologias de produção agropecuárias. Nesse contexto, o estudo da inserção do arroz no Mato Grosso pode representar contribuição 
importante na descrição do comportamento das culturas quanto à expansão da área agrícola e do sistema de produção empregado.

As propriedades mato-grossenses não têm o arroz como fonte exclusiva e/ou principal fonte de renda da empresa agrícola (ao contrário das gaúchas); normalmente as propriedades exploram outras atividades econômicas como soja, milho, algodão, madeira, pecuária, etc.

Na agricultura brasileira, o arroz perde em valor de produção somente para a soja, a cana-de-açúcar e o milho, desbancando culturas tradicionais da agricultura nacional, como a laranja e o café em coco. Na Tabela 7 são apresentados dados sobre o valor bruto da produção na agricultura brasileira. Verifica-se que a orizicultura tem grande importância nesse contexto.

Tabela 7. Valor bruto da produção agrícola brasileira em 2001.

\begin{tabular}{ccc}
\hline Cultura & Localidades & VBP (em mil R\$) \\
\hline Soja & Brasil & $10.978 .610,0$ \\
Cana-de-açúcar & Brasil & $8.677 .381,0$ \\
Milho & Brasil & $6.316 .996,0$ \\
& Rio Grande do Sul & $1.629 .508,0$ \\
Arroz & Mato Grosso & $255.941,0$ \\
& Brasil & $2.998 .378,0$ \\
Café (em coco) & Brasil & $2.846 .565,0$ \\
Laranja & Brasil & $2.603 .675,0$ \\
Total & Brasil & $53.853 .402,0$ \\
\hline
\end{tabular}

Fonte: IBGE (2003b)

O arroz de terras altas apresenta uma ampla variabilidade de sistemas produtivos, enquanto o sistema de cultivo de arroz irrigado tem pequena variação, gerando um produto de melhor qualidade. No sistema de terras altas, os riscos climáticos são mais intensos, resultando em um produto bastante heterogêneo e de menor 
qualidade. No entanto, esforços estão sendo envidados e esse sistema de cultivo vem apresentando significativa evolução tecnológica nos últimos anos, principalmente na década de 1990. Souza \& Arbage (2002) relatam que o desenvolvimento de variedades de arroz de terras altas mais produtivas e adaptadas ao cerrado, com características semelhantes às do arroz longo fino do Rio Grande do Sul, tem exercido forte pressão de custos sobre os produtores gaúchos.

Observa-se, na Tabela 8, a estabilidade do consumo brasileiro de arroz ao longo da segunda década de 90, ao mesmo passo em que houve aumento da quantidade exportada e pequena diminuição da quantidade importada. Verifica-se também redução nos estoques nacionais de arroz.

Tabela 8. Balanço de oferta e demanda de arroz no Brasil (em mil t).

\begin{tabular}{cccccccc}
\hline \multirow{2}{*}{ Safra } & $\begin{array}{c}\text { Estoque } \\
\text { inicial }\end{array}$ & Produção & Importação & Suprimento & Consumo & Exportação & $\begin{array}{c}\text { Estoque } \\
\text { final }\end{array}$ \\
\hline $1997 / 98$ & $1.756,0$ & $8.462,9$ & $2.013,6$ & $12.232,5$ & $11.750,0$ & 9,9 & 472,6 \\
$1998 / 99$ & 472,6 & $11.582,2$ & $1.397,5$ & $13.452,3$ & $12.050,0$ & 37,7 & $1.364,6$ \\
$1999 / 00$ & $1.364,6$ & $11.423,1$ & $1.008,3$ & $13.796,0$ & $11.950,0$ & 21,1 & $1.824,9$ \\
$2000 / 01$ & $1.824,9$ & $10.386,0$ & $1.023,6$ & $13.234,5$ & $11.850,0$ & 24,4 & $1.360,1$ \\
$2001 / 02$ & $1.360,1$ & $10.626,1$ & 780,2 & $12.766,4$ & $11.981,1$ & 21,9 & 763,4 \\
$2002 / 03$ & 763,4 & $10.359,5$ & $1.500,0$ & $12.622,9$ & $12.100,9$ & 20,0 & 502,0 \\
\hline
\end{tabular}

Fonte: Conab (2003)

Um grande entrave para o aumento do consumo de arroz no Brasil é a sua baixa elasticidade-renda e baixa elasticidade-preço da demanda. Acredita-se que, possivelmente, a única forma de se elevar o consumo desse cereal seja pelo aumento da população. Os trabalhos relativos a estimativas de elasticidades de oferta e de demanda de arroz no Brasil são escassos. Bos (1986) estimou, com base em dados de 1966 a 1983, a elasticidade-preço da oferta de arroz em 0,21. Santi et al. (1978), analisando dados de 1953 a 1976, estimaram a elasticidade-preço da oferta em 0,3 e a elasticidade- 
preço da demanda em -0,31. Calcanhoto et al. (1999) estimaram a elasticidade-preço da oferta de arroz no Rio Grande do Sul em 0,370.

Bevenuto \& Souza (1994) estimaram a elasticidade-renda e elasticidadepreço da demanda do arroz em 0,24 e 0,02, respectivamente, para o período de 1988 a 1992.

Hoffmann (2000) calculou, com dados da POF de 1995/96, a elasticidaderenda do dispêndio de vários produtos alimentícios, entre eles o arroz, apresentando uma elasticidade média de 0,014.

Martins (1998) estimou as elasticidades-renda da despesa de vários alimentos utilizando ajustamento de poligonais, com base nos dados da POF de 1987/88. A elasticidade-renda média do arroz foi calculada em 0,009.

\subsection{Fontes de crescimento da produção agrícola}

Torna-se uma tarefa bastante difícil descrever as fontes de crescimento da produção agrícola, em especial a do arroz no Mato Grosso, sem discorrer, ao menos superficialmente, sobre o processo de crescimento da agricultura brasileira como um todo.

Conforme citado anteriormente, a agricultura brasileira passou por profundas transformações decorrentes de alterações na política agrícola e em programas econômicos, resultando em uma agricultura moderna e competitiva no cenário internacional.

Segundo Alves \& Contini (1992), o uso de tecnologia moderna e os investimentos na indústria possibilitaram o aumento da produtividade da terra e do trabalho, opção tomada pelo país na década de 1960, quando houve um forte investimento na implantação do parque agroindustrial brasileiro, provocando mudança na base técnica do setor, principalmente na região Centro-Sul.

Smith (1983) argumenta que, nas décadas de 50 e 60, a política adotada para enfrentar o problema de oferta de alimentos foi baseada na expansão da fronteira 
agrícola, possível pela ampliação da rede de transportes e pela melhoria da infraestrutura de armazenamento.

Barros \& Araújo (1991) relatam que a agricultura, antes de 1970, cresceu principalmente pela incorporação de novas áreas e pelo emprego de mão-de-obra. Durante a década de 1970, a política agrícola tinha como objetivo o aumento da produtividade da terra e do trabalho, por meio da modernização do setor. Houve incentivo à pesquisa e à extensão rural, mas foi o crédito rural subsidiado que proporcionou o crescimento estável da produção. Olivetti \& Camargo (1992) afirmam que um eficiente sistema de pesquisa e extensão rural é essencial para proporcionar o aumento da produção. Segundo Araújo \& Meyer (1979), o intuito da política de crédito rural brasileira visava modernizar a agricultura por meio da aquisição de insumos modernos. Barros \& Araújo (1991) argumentam que o crescimento da agricultura foi baseado no uso intensivo de insumos e estimulou o desenvolvimento do parque agroindustrial brasileiro, conforme a meta do programa de industrialização, que visava a substituição das importações. Porém, este mesmo estudo aponta a redução dos recursos disponíveis à agricultura e que esforços foram envidados no sentido da diminuição do subsídio implícito nas taxas de juros. O governo, como fonte de financiamento da agricultura, se retraiu, forçando o setor a buscar fontes alternativas de recursos. A Figura 4 retrata a evolução do volume de crédito rural disponibilizado entre 1969 e 2001. Os valores do crédito rural foram deflacionados para 2001, utilizando como deflator o Índice Geral de Preços - disponibilidade interna (IGP-DI) da Fundação Getúlio Vargas (FGV). 


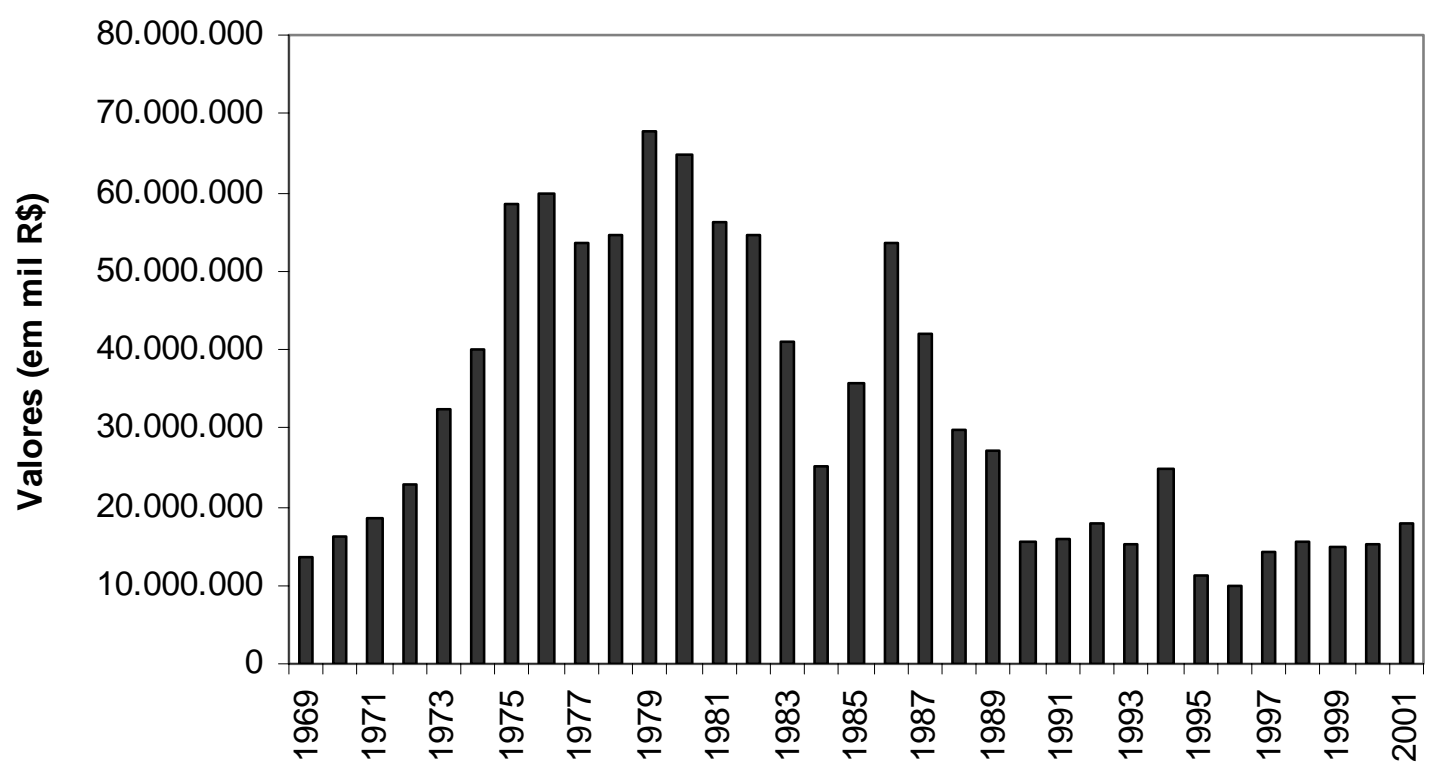

Figura 4 - Evolução de recursos de crédito rural, de 1969 a 2001.

Fonte: Banco Central do Brasil (2003)

Observa-se, na Figura 4, o alto volume de crédito rural para o financiamento do setor agrícola e pecuário nas décadas de 70 e 80. Esses recursos foram fundamentais na expansão da fronteira agrícola, na aquisição de máquinas e insumos e no desenvolvimento de inovações tecnológicas.

Mesquita (1994) argumenta que a estabilidade cambial, o aumento dos preços recebidos pelos produtores e a redução de custos associados aos fertilizantes e aos combustíveis, além da abundância e do baixo custo do crédito rural, marcaram a década de 70. Barros (1979) aponta o aumento de 52\% dos preços reais dos alimentos entre 1970 e 1977. Mesquita (1994) divide o período de 1970 a 1990 em duas fases. Nos anos 70, as condições para o crescimento da agricultura e da economia como um todo foram favoráveis, apesar do primeiro choque do petróleo em 1973. Já a década de 1980 foi marcada por crises, como o segundo choque do petróleo, a queda dos preços dos produtos agrícolas no mercado internacional e, internamente, a recessão de 1981-83, seguida pela elevação do nível geral de preços. As diversas tentativas de estabilização 
econômica, incluindo choques heterodoxos, perturbaram a economia como um todo e trouxeram sérias conseqüências para a agricultura, como um acentuado declínio do crédito rural.

A recessão que acometeu o país na década de 80 , quando se verificou taxa negativa de crescimento, provocou instabilidade na comercialização agrícola, nos investimentos rurais, na produção industrial de insumos modernos e nos preços das terras para agricultura. Ocorreu ainda a redução dos volumes do crédito rural e a diminuição dos preços mínimos, o que resultou em menor demanda pelos insumos modernos, gerando uma crise no setor agrícola (Barros \& Álvaro, 1992).

Mello (1990) afirma que o setor agrícola na década de 1980, mesmo enfrentando dificuldades em termos de disponibilidade de crédito oficial e redução de subsídios, conseguiu ter bom desempenho devido à melhoria da produtividade, à política cambial favorável à exportação e a outras medidas de política agrícola.

Apesar das dificuldades verificadas da década de 80, - decorrentes da recessão mundial, do segundo choque do petróleo, da baixa nos preços nacionais e internacionais dos produtos agrícolas, do crescimento da dívida pública brasileira, do aumento da inflação, da diminuição da oferta de crédito agrícola no final da década e da redução gradual dos subsídios, a agricultura teve um desempenho médio bem superior ao da indústria (Nakano, 1992), fato também relatado por Gasques \& Verde (1990). Nakano (1992) argumenta que o crédito abundante e subsidiado existente até meados da década de 80 permitiu a capitalização da agricultura e a incorporação de novas áreas agrícolas do Centro-Oeste, assim como a modernização do setor.

Rezende (1989) verificou que a agricultura cresceu a taxas elevadas na década de 80 e que um dos fatores responsáveis pela manutenção dessa tendência foi a produção voltada para o mercado interno. Concluiu ainda que as flutuações de curto prazo do produto agrícola não estavam correlacionadas ao ciclo geral da atividade econômica. Segundo o autor, o câmbio, os preços mínimos e o crédito subsidiado até meados da década foram os instrumentos que contribuíram para o crescimento da agricultura. 
Belik (1998), em estudo que trata das mudanças na política agrícola brasileira, argumenta que a regulação do setor agrícola e da agroindústria passou por três fases distintas nos últimos 30 anos. A primeira fase, de 1964 até o final da década de 1970, foi marcada pela forte presença do Estado, determinando o crescimento do setor agropecuário e sua articulação com setores à montante e à jusante. Neste período, os governantes disciplinaram praticamente todos os aspectos da política agrícola, na qual predominavam os instrumentos clássicos, tais como crédito, preços mínimos e outros.

A segunda fase compreende o final dos anos 70 até o final dos anos 80 , com a política agrícola motivada pela redução dos subsídios e pela busca da "autoregulação", o que pode ser constatado pelo financiamento verticalizado observado nos complexos agroindustriais (CAIs). Houve o fortalecimento de instituições e atores da iniciativa privada e um peso cada vez menor do setor público.

A terceira fase iniciou-se no fim da década de 1980 e foi caracterizada pelo desmonte das instituições e dos instrumentos que nortearam a política agrícola e agroindustrial desde a criação do Sistema Nacional de Crédito Rural (SNCR). Os volumes de crédito destinados ao setor agropecuário atingiram os níveis mais baixos, as tradicionais arenas regulatórias foram desativadas, ao mesmo tempo em que ocorria o acelerado processo de abertura comercial e integração regional, afetando sobremaneira o segmento agropecuário e agroindustrial, havendo perda do poder regulatório e da capacidade de planejamento do Estado.

Dias \& Amaral (1999) afirmaram que, durante as décadas de 60 e 70, o governo injetou grandes volumes de crédito rural subsidiado, interferiu no sistema de preços relativos com as políticas de estoques reguladores e protegeu os mercados de produtos e insumos. A partir da segunda metade da década de 1980, foi implantado progressivamente um conjunto de reformas estruturais liberalizantes, concretizadas nos Planos Collor I, Collor II e Plano Real, com a eliminação de todas as proibições de importações, desmantelamento de órgãos e monopólios estatais. De acordo com o autor, o governo sempre controlou o financiamento da agricultura e, ao longo da década de 80, perdeu a capacidade de gerar recursos. O setor agrícola vivenciou o esfacelamento dos instrumentos de intervenção, principalmente do crédito para investimento e da política 
de garantia de preços mínimos (PGPM). Ainda segundo o autor, o ponto positivo da intervenção governamental foi que ela possibilitou a criação de infra-estrutura, o avanço tecnológico e a expansão da fronteira agrícola na Região Centro-Oeste.

Baer (2002) verificou que, durante toda a década de 50 e meados da década de 60, as políticas industriais discriminaram o setor agrícola. A expansão da produção agrícola ocorreu em condições retrógradas, com métodos de cultivo e colheita tradicionais e intensivas em mão-de-obra. Ao fim da década de 60, ocorreram mudanças no método de produção agrícola, com uma combinação de planejamento e progressão natural. A política agrícola e as receitas de exportação potenciais estimularam o fluxo de capital urbano-industrial para o setor agrícola. O sistema de produção brasileiro, baseado em latifúndios e minifúndios, deu espaço a um moderno complexo agroindustrial. O aumento da produtividade da terra, com o uso de tratores, fertilizantes e outros insumos de alta tecnologia, era o foco de alguns setores. No entanto, mesmo com o aumento da produtividade da terra, propiciado pela "revolução verde", ocorreu o crescimento da produção baseado no aumento da área agricultável. Conforme o autor, a expansão da produção agrícola voltada para exportação recebeu atenção especial por causa da necessidade de melhoria da balança comercial devido às pressões inflacionárias causadas pela crise do petróleo em 1973. Baer ressalta as deficiências do setor agrícola brasileiro causada pela produção insuficiente de alimentos para o consumo interno, devido, em grande parte, à falta de crédito, a preços desestimulantes e a políticas macroeconômicas que discriminavam a agricultura voltada à produção para o consumo doméstico.

Queda et al. (1979), analisando as culturas do arroz e do feijão, concluíram que, nos estados onde a agricultura assume o caráter capitalista, as culturas de baixo valor por unidade de área tendem a ser substituídas. Camargo (1983) considera que uma das características da evolução da agricultura brasileira desde 1960 foi a acentuada diferença entre as taxas de crescimento das diversas atividades. As culturas passíveis de influência do mercado externo expandiram-se em ritmo bem mais acelerado que as culturas destinadas ao mercado interno. 
A taxa de crescimento médio anual das culturas alimentares, no período de 1966-67, foi de apenas 3,3\%, enquanto a taxa de crescimento médio das culturas de exportação, no mesmo período, foi de 20\% (Levy et al., 1979). Manoel \& Barros (1987) argumentam que as distinções entre as chamadas culturas domésticas e de exportação seriam minimizadas no longo prazo. Barros \& Graham (1978) estimaram a taxa de crescimento das culturas exportáveis ${ }^{1}$ em $5 \%$ a.a., enquanto as culturas domésticas apresentaram decréscimo de 4\% a.a. de 1970 a 1975. Goldin \& Rezende (1993) estimaram a taxa de crescimento médio anual das culturas exportáveis e domésticas no período de 1971-1980, destacando-se o crescimento da produção de soja (18,6\% a.a.), arroz (2,7\% a.a.), milho (2,6\% a.a.) e o decréscimo na produção de algodão (-4,8\% a.a.). Melo (1983) também calculou a taxa de crescimento da produção de culturas destinadas ao mercado interno e externo de 1970 a 1979, sendo que o arroz e o milho cresceram à taxa de 1,46\% a.a. e 1,75\% a.a., respectivamente. Já a cultura da soja, cresceu à taxa de $22,47 \%$ a.a., enquanto que a do algodão decresceu à taxa de 4,41\% a.a.. Silva (1991) estimou a taxa de crescimento anual das culturas exportáveis e domésticas no período de 1977 a 1988 em 4,87\% a.a. e 3,42\% a.a., respectivamente. Alves (2001) calculou a taxa de crescimento de lavouras selecionadas na década de 1990, destacando a soja (6,3\% a.a.), o milho (3,2\% a.a.) e o arroz (1,0\% a.a.). A exposição da agricultura brasileira ao comércio internacional, simultaneamente à redução da participação do governo no setor agrícola, induziu ao maior equilíbrio entre os grupos de produtos.

Baer (2002) afirma que, a partir da segunda metade da década de 1980 e início da década de 1990, a produção de alimentos teve um grande salto, devido, em parte, à eliminação de políticas discriminatórias, principalmente para o caso do arroz e do milho. Com isso, surgiu uma moderna área irrigada de arroz no Rio Grande do Sul, que atualmente responde por mais da metade da produção brasileira. A modernização também ocorreu no desenvolvimento de complexos industriais que afetavam o processamento e o comércio dos produtos. O autor destaca a modernização agrícola

\footnotetext{
${ }^{1}$ Segundo Barros \& Graham (1978), as culturas exportáveis eram o algodão, cacau, café, cana-de-açúcar, fumo, laranja e soja, enquanto as culturas domésticas eram o arroz, cebola, feijão, mandioca, milho, tomate e o trigo.
} 
ocorrida nas décadas de 70 e 80 em algumas regiões de cerrado central brasileiro, assim como no Paraná, no Rio Grande do Sul e em parte de Minas Gerais.

Ainda segundo Baer (2002), o afastamento do Estado do setor agrícola no início da década de 90 foi marcado pela redução do crédito subsidiado e dos preços mínimos. Houve reformas que visavam à estabilização dos preços domésticos, e entre elas pode-se citar a definição de preços mínimos de produtos agrícolas compatíveis com os preços no mercado internacional. A política de preços mínimos na década de 1990 tinha por objetivo incentivar a produção de acordo com as projeções de demanda dos produtos agrícolas. Além disso, o governo instituiu uma política de estoques reguladores que complementava as políticas de preços.

Após a implantação do Plano Real, muitos produtores ficaram em uma situação desconfortável, pois a correção monetária das dívidas era bem superior ao aumento dos preços dos seus produtos. Como conseqüência, os produtores tornaram-se mais seletivos, cultivando os produtos nos quais eles tinham maior controle e apoio tecnológico e que podiam lhes oferecer maior rentabilidade. Diante disso, surgiu um novo modelo no Brasil, em que o setor agrícola estava integrado cada vez mais a um complexo industrial e a um sistema de distribuição influenciado pelas cadeias de supermercados. As agroindústrias, os processadores de “commodities” e o setor de insumos agrícolas passaram a ser a principal fonte de financiamento da produção agrícola, substituindo as fontes de crédito público (Baer, 2002). Dias \& Amaral (1999) levantaram como hipótese que a redução do crédito estimulou os produtores a diminuírem os custos médios de produção. Isso teria resultado em aumento da produtividade e em uma forte redução do uso da mão-de-obra. Segundo Barros (1999), a abertura da economia e a redução dos recursos destinados à agricultura forçaram o aumento da eficiência produtiva. A diminuição dos subsídios implícitos no crédito rural alterou os preços relativos dos fatores de produção, propiciando uma alocação mais eficiente dos mesmos. A elevação da produtividade foi decorrente do uso mais racional dos fatores e da disseminação dos resultados da pesquisa agronômica.

Percebe-se pelos trabalhos citados que a agricultura brasileira cresceu, em um primeiro momento, pela expansão da área agricultável e, apenas recentemente, a 
elevação da produtividade contribuiu de maneira representativa para o crescimento da produção.

Hayami \& Ruttan (1975) consideram que, para promover o crescimento agrícola, é necessário habilidade para escolher e pôr em prática inovações tecnológicas que facilitem a substituição de fatores de produção relativamente escassos por outros relativamente abundantes. Desta maneira, inovações mecânicas levariam a uma maior produtividade do trabalho quando a mão-de-obra é escassa. Ao contrário, em países ou regiões em que a terra é fator de produção escasso, as inovações biológico-químicas seriam fundamentais para aumentar a produtividade da terra. Os autores defendem a tese de que a diferença de produtividade entre regiões e países depende da quantidade e da qualidade dos recursos naturais disponíveis, da tecnologia incorporada ao capital fixo, do trabalho e do capital humano. Consideram ainda que as nações devem ter capacidade industrial para produzir insumos modernos.

Curtis (1972) utilizou a técnica de "shift-share" para analisar as mudanças nas variáveis renda e emprego de economias rurais no Alabama, decompondo-as em três efeitos: crescimento nacional, composição das atividades econômicas e diferenciação regional das atividades econômicas. Esse foi o primeiro trabalho a utilizar tal metodologia em um estudo sobre o setor agrícola.

Patrick (1975) estudou as fontes de crescimento da agricultura brasileira no período de 1948 a 1969 decompondo a variação na produção em quatro componentes: efeito área, efeito rendimento, efeito composição e efeito localização geográfica. Observou uma forte participação do efeito área no crescimento da produção, com grande uso do trabalho e formas tradicionais de capital. Verificou que o aumento da produção está fortemente associado ao efeito área e em segundo lugar ao efeito rendimento. O autor também considera o aumento do uso de recursos tradicionais, a alocação mais eficiente dos fatores de produção, as economias externas e os fenômenos naturais como fontes de variação da produção agrícola.

Zockun (1978), analisando a expansão da soja no Brasil, desenvolveu um método descritivo semelhante ao modelo "shift-share", em que se identificam, na alteração da área total agrícola ou pecuária, dois efeitos distintos: um efeito devido à 
alteração na escala do sistema de produção e um efeito devido à substituição de culturas dentro do sistema. O autor concluiu que a expansão da soja foi devida mais ao efeito substituição (88\%) do que ao efeito escala (12\%).

Barros et al. (1983), estudando a evolução da agricultura brasileira no período de 1940 a 1971, subdividiram a taxa de crescimento da produtividade agrícola em: produtividade da terra, aumento da relação área/homem e aumento da mão-de-obra. Os autores verificaram um crescimento da área cultivada a partir de 1950, devido, em grande parte, à recuperação na produção dos produtos exportáveis e ao crescimento da área de cultivo dos produtos industrializáveis na década de 60. Pelo fato de o país ser detentor de uma ampla fronteira agrícola a ser explorada e ter uma grande população, os dois fatores abundantes, terra e mão-de-obra, foram bastante utilizados até 1960. Inicialmente, a taxa de crescimento da mão-de-obra foi importante no aumento da produção e, a partir de 1960, percebeu-se maiores ganhos na produtividade da terra e na relação área/homem.

Cunha \& Daguer (1982), em estudo de crescimento agrícola abordando o decênio 1967/69 a 1977/79 e utilizando a metodologia "shift-share", discutiram a proposição de que a principal fonte de crescimento da agricultura brasileira foi a expansão da área cultivada e que a produtividade da terra não respondeu, como se esperava, ao aumento do uso de insumos modernos. Os autores argumentaram que a política governamental de estímulo à modernização, a mudança dos preços relativos dos fatores de produção e o esgotamento do crescimento extensivo das áreas agrícolas tradicionais, têm contribuído para o crescimento baseado no aumento da produtividade. Cunha \& Daguer (1982) argumentaram que, apesar da incorporação de novas áreas, essa tendência indica o esgotamento da fase de expansão. Patrick (1975) e Cunha \& Daguer (1982) concluíram que o aumento da área cultivada ainda é a principal fonte de crescimento da agricultura brasileira, fato esse cabível ao arroz e à maioria das outras culturas pesquisadas pelos autores; de outro lado, as hortaliças tiveram como fonte principal de crescimento a produtividade e o café e o sisal, o efeito localização geográfica. 
Igreja et al. (1983) adaptaram a metodologia proposta por Patrick (1975) para analisar o desempenho da agricultura paulista de 1966-1977. Os autores estudaram as fontes de variação da produção na agricultura paulista por região e por culturas e constataram que o efeito área foi o maior responsável pela expansão da produção em todos os níveis da análise. A composição da produção foi o segundo fator em ordem de importância na explicação das variações, fornecendo indícios de que a diferença da produção agrícola decorreu do crescimento mais rápido das culturas exportáveis e industrializáveis.

Camargo (1983) estudou as alterações ocorridas nos padrões de cultivo das Divisões Regionais Agrícolas (DIRAs) do Estado de São Paulo, nos períodos de 1968/69 a 1979/80, por meio de análise comparativa entre culturas de exportação, de abastecimento interno e pastagens. Os resultados demonstraram que, na década de 70 e 80, as culturas de mercado interno e pastagens tiveram redução na área cultivada, ao contrário do que ocorreu com as culturas que geravam produtos exportáveis. Foram cedidos 2,5 milhões de hectares provenientes de pastagens naturais, café, arroz, feijão, reflorestamento, algodão, amendoim e milho no período de 1983 a 1993, dos quais 96,8\% foram incorporados por atividades de maior rentabilidade, como pastagens cultivadas, laranja, cana-de-açúcar e soja. Foram verificadas, em todas as regiões, mudanças na composição da produção e intensificação da especialização.

Gasques \& Verde (1990) e Olivetti \& Camargo (1992), utilizando a metodologia modificada por Camargo (1983) na análise dos efeitos escala e substituição, avaliaram o crescimento da agricultura brasileira, relacionando-a com as políticas agrícolas vigentes na década de 70 e 80 . Chegaram à conclusão de que, na década de 70, a composição da produção agrícola foi alterada por influência das políticas agrícolas, principalmente do crédito subsidiado que visava à modernização do setor, beneficiando as culturas voltadas à exportação e os substitutos energéticos. No decorrer da década de 80 , as culturas originalmente de mercado interno estavam sendo substituídas por culturas que apresentavam mercado mais estável e lucrativo. Mesmo com a redução dos preços reais observada ao longo da década, a produção agrícola cresceu em decorrência das alterações da composição da produção agropecuária, dos ganhos em rendimento, da 
diminuição dos custos dos insumos e das políticas governamentais que sustentavam o setor. Gasques \& Verde (1990) concluíram que as principais transformações com relação à pesquisa agronômica ocorreram nas regiões Nordeste e Centro-Oeste.

Fassarella (1987), estudando as fontes de crescimento das culturas agrícolas no Estado do Espírito Santo, no período de 1970 a 1980, verificou que a variação do rendimento foi a mais importante, indicando que a agricultura capixaba sentiu os efeitos das políticas de modernização do setor, das pesquisas agrícolas e do crédito subsidiado. O autor alertou para a escassez de áreas disponíveis, fazendo com que o efeito rendimento sobressaísse ao efeito área, contrastando com outros estudos realizados para outros estados, em que o efeito área foi o maior responsável pela expansão da produção nas décadas de 60 e 70 . O resultado comum a outros estudos foi o de que as culturas de exportação e industrializáveis foram preferidas às culturas de mercado interno, podendose atribuir tal fato aos incentivos à exportação concedidos.

Yokoyama (1988), ao analisar o crescimento da produção de lavouras em Goiás, verificou que o arroz foi uma das culturas que mais cederam área para a soja. A produção do arroz apresentou uma taxa de crescimento de $0,42 \%$ ao ano. A retração na área foi de 0,76\% a.a., explicada basicamente pelo efeito substituição negativo (-3,98\% a.a.). O rendimento apresentou uma taxa de crescimento de $1,36 \%$ a.a., refletindo o maior grau de modernização e racionalização no cultivo, assim como a instalação de projetos de arroz irrigado.

Moreira (1996), estudando as fontes de crescimento das principais culturas do Rio Grande do Norte, de 1981 a 1992, observou que o arroz foi a única cuja produção cresceu, mesmo com a retração da área plantada. A produção de arroz apresentou taxa de crescimento positiva de $7,46 \%$ ao ano. Os efeitos composição da produção, rendimento e localização geográfica foram os mais importantes na explicação da variação da taxa de crescimento da produção. O crescimento da produção não ocorreu pelo efeito área, tendo se verificado uma retração nas áreas cultivadas com as principais culturas. As políticas de crédito subsidiado que incentivaram o uso dos insumos modernos, a expansão e melhoria das pesquisas agrícolas e da extensão rural podem ter influenciado a produtividade das culturas analisadas. Ao se levar em consideração que o 
fator de produção terra é escasso, as inovações tecnológicas poupadoras desse fator constituem elemento-chave para aumentar a produção agrícola, conforme a teoria de Hayami \& Ruttan (1975).

Curi (1997), ao analisar a eficiência e as fontes de crescimento da agricultura mineira, verificou que o arroz, entre outros produtos, teve aumento do rendimento médio, embora este tenha ficado bem aquém do verificado em outros estados que se encontram na fronteira tecnológica de produção. $\mathrm{O}$ autor percebeu ainda uma redução na área total cultivada de arroz, feijão, milho e algodão. Houve uma considerável expansão na produção das culturas de exportação (cana-de-açúcar, café, soja e laranja), que tiveram taxa positiva de crescimento em detrimento das culturas destinadas ao mercado interno, tais como o arroz, que teve taxa negativa de crescimento, e o feijão, que apresentou um crescimento pouco expressivo. Aliás, o arroz foi a única cultura em estudo que apresentou taxa negativa de crescimento da produção. $\mathrm{O}$ arroz, algodão, alho e feijão apresentaram o efeito localização geográfica positivo e o efeito composição da produção negativo.

Alves (2000) estudou as fontes de crescimento das principais culturas do Paraná, no período de 1981 a 1999, e verificou que o arroz apresentou produção decrescente (a taxa de 5,0\% a.a.) devido à diminuição da área (5,65\% a.a.) e ao efeito localização negativo ( $0,01 \%$ a.a.). O efeito rendimento foi positivo de $0,66 \%$ a.a..

Alguns dos trabalhos acima citados utilizaram a metodologia "shift-share" que foi empregada no presente estudo para explicar o comportamento da produção agropecuária brasileira. Outros que tratam dessa metodologia, não discutidos aqui, são encontrados na literatura brasileira, como Ghilardi (1987), Mello (1990), Veiga Filho \& Yoshii (1990), Martin et al. (1992), Olivetti \& Camargo (1992), Camargo et al. (1995), Cardoso (1995). Alguns desses estudos mencionados também discorrem sobre a cultura do arroz.

A literatura econômica nacional envolvendo estudos de comercialização e integração de mercados de arroz é bastante escassa, sobretudo se tratando de arroz de terras altas. 
Junqueira et al. (1968), estudando os fluxos de comercialização de arroz em São Paulo, perceberam que o Rio Grande do Sul, Minas Gerais e Goiás foram os principais exportadores de arroz para aquele estado, enquanto o Rio de Janeiro, Santa Catarina, Mato Grosso e Maranhão tinham menor importância no abastecimento de São Paulo. A preferência dos consumidores paulistas por tipo de arroz, no período de 1950 a 1965, em termos qualitativos, era o arroz longo, procedente de Goiás e Minas Gerais, os quais tinham preço mais elevado. O arroz gaúcho, porém, sempre esteve presente em São Paulo, devido à estabilidade da safra. Sua entrada era maior quando as condições climáticas adversas prejudicavam a produção do arroz de sequeiro. Utilizando um levantamento realizado em 1966, os autores estimaram que 50\% do produto consumido em São Paulo, naquele ano, foi proveniente do Rio Grande do Sul, 18\% de Minas Gerais, $17 \%$ de Goiás, $8 \%$ era do próprio estado e os outros $7 \%$ de outras fontes. A forte entrada do arroz gaúcho em São Paulo resultou da redução da safra dos outros estados. No período de 1960-67, exceto em 1966, o Estado de São Paulo produziu cerca de 60\% a $90 \%$ do seu consumo.

Smith (1973), em um vasto estudo sobre comercialização que envolvia quatro décadas (1930 - 1970), segmentou a comercialização do arroz em três fases distintas. A primeira compreendeu o período de 1930 a 1950, quando o mercado era centralizado e oligopsônico, em São Paulo e Porto Alegre, com o transporte do arroz realizado por trens e navios. O sistema de crédito era precário e os grandes atacadistas financiavam a produção agrícola. O mercado era pouco competitivo, incorrendo em altas margens de comercialização. Nesse período, a maioria dos brasileiros preferia o arroz de terras altas. A parte da população de renda mais baixa consumia o arroz do Rio Grande do Sul, que tinha um preço inferior. A segunda fase se estendeu de 1951 até 1967, período marcado pela descentralização e pelo aumento da competição na distribuição do arroz. Os investimentos em vias rodoviárias foram intensificados, o sistema de crédito rural foi expandido e a produção evoluiu, rompendo os oligopsônios. A entrada de novos compradores no mercado de arroz implicou em redução das margens. O período de 1968 a 1970 representou a terceira fase, com novas características na comercialização de arroz - que perduram até hoje, como o aumento da participação de marcas comerciais e 
porções pré-empacotadas, atenção quanto às preferências dos consumidores e melhoria na qualidade do produto.

González-Rivera \& Helfand (1999) realizaram um estudo utilizando a metodologia de análise multivariada com restrições de co-integração para determinar os limites geográficos do mercado de arroz brasileiro, o padrão de independência e o grau de integração entre os estados produtores de arroz. Utilizaram a metodologia dos perfis de persistência para calcular o grau de integração. O perfil de persistência foi calculado de acordo com a metodologia descrita por Pesaran \& Shin (1996). Esses autores observaram que 15 dos 19 estados analisados pertenciam ao mesmo mercado. A região Sudeste pode ser caracterizada como o centro do mercado de arroz. Os estudos de velocidade de ajustamento realizados pelos autores indicaram que os desequilíbrios entre os estados do Centro-Oeste e São Paulo desapareciam mais rapidamente, demonstrando um maior grau de integração entre esses mercados.

Rezende (2001) fez uma análise simplificada da integração de mercado de arroz, milho e soja entre estados da região Centro-Sul, comparando os preços na safra e entressafra com os custos de transporte dos produtos citados. Verificou consistência entre esses diferenciais de preço e custo de transporte, indicando viabilidade entre o comércio do Rio Grande do Sul e São Paulo. Ainda conforme Rezende (2001), o comércio de arroz mostrou-se viável para os estados de Goiás e do Mato Grosso do Sul. No entanto, o comércio do Mato Grosso com os demais estados do Sudeste apresentouse mais viável do que nos casos de Goiás e Mato Grosso do Sul, o que pode ser atribuído ao ganho de competitividade do "novo" arroz e da expansão da produção daquele estado, combinados com a redução da produção nos outros estados do Centro-Oeste. O autor afirmava que o comércio do arroz é viável o ano inteiro, não havendo diferenciação de safra e entressafra, como no caso do milho. Havia uma especialização regional da produção com a indústria arrozeira instalada próxima às áreas produtoras. Esse autor levanta três hipóteses para explicar a queda da participação do arroz do Centro-Oeste, exceto do Mato Grosso, no mercado do Sudeste: ou os estados deixaram de ser exportadores, ou perderam a competitividade no abastecimento do Sudeste, ou 
estão dirigindo as vendas para outros mercados, como o Nordeste, que havia registrado uma intensa queda na produção de arroz.

González-Rivera \& Helfand (2001) aprimoraram o estudo do mercado brasileiro de arroz utilizando uma aproximação multivariada. Também nesse caso observaram que, dos 19 estados produtores analisados, 15 faziam parte de um único mercado. O objetivo desse trabalho foi mostrar as vantagens da análise multivariada e acentuar as limitações da análise bivariada em estudos de integração de mercados. A estrutura da análise multivariada permite, segundo os autores, determinar os limites geográficos do mercado e utilizar os perfis de persistência para medir o grau de integração de diferentes localidades que pertencem ao mercado. O teste do perfil de persistência mostrou que os desequilíbrios são removidos mais rapidamente entre Minas Gerais e São Paulo, e mais vagarosamente entre Maranhão e São Paulo. A convergência ao equilíbrio acontecia de maneira mais rápida entre os estados vizinhos e os que estavam ligados diretamente pelo comércio.

Martins et al. (2002) estudaram a evolução da comercialização do arroz em São Paulo em três níveis de mercado, considerando os últimos 25 anos. Observaram que, neste período, o estado apresentou significativas transformações, nesse contexto passando a importar 95\% do arroz consumido, especialmente do Rio Grande do Sul, impulsionado pela alteração da preferência do consumidor paulista pelo tipo de arroz produzido no estado gaúcho. O consumidor do Estado de São Paulo passou a exigir grãos longos e finos, produzidos em lavouras irrigadas. De forma geral, observaram reduções nos preços reais em todos os níveis de mercado, com picos de elevação em anos de baixa oferta. 


\section{MATERIAL E MÉTODOS}

\section{1 Área de estudo}

O presente trabalho abrange o Estado do Mato Grosso e mais especificamente as microrregiões compostas pelos municípios de: Água Boa, Alta Floresta, Campos de Júlio, Cláudia, Colíder, Comodoro, Diamantino, Guarantã do Norte, Lucas do Rio Verde, Matupá, Nova Canaã do Norte, Nova Mutum, Nova Ubiratã, Novo Mundo, Paranatinga, Peixoto de Azevedo, Primavera do Leste, Querência, Santa Carmem, Sinop, Sorriso, Tapurah, Terra Nova do Norte e Vera, visitados durante o mês de abril de 2002, quando foram aplicados 34 questionários (Anexos A e B), sendo 23 junto a produtores e 11 junto a agroindústrias, incluindo armazéns, com o objetivo de realizar a descrição do sistema produtivo do arroz. As informações contidas nesses questionários são utilizadas como ferramentas para explicar os sistemas produtivos adotados e o comportamento da cultura do arroz perante as demais atividades agrícolas representativas do estudo.

Os municípios foram escolhidos pela sua importância na produção, no beneficiamento e na distribuição do cereal, identificados anteriormente por meio de pesquisa em fontes secundárias e conhecimento empírico do setor. Os municípios são representativos das principais microrregiões produtoras e estão divididos, basicamente, em quatro regiões distintas, conforme citado anteriormente, separadas espacialmente por rodovias precárias, dificultando o comércio entre as regiões, principalmente o da parte oeste com a porção central do estado. Identifica-se, no Apêndice 1, os municípios que compõem as microrregiões homogêneas (MRH) do Estado do Mato Grosso. As MRH do Mato Grosso estão classificadas para efeito de estudo em ordem decrescente de 
produção, de acordo com os dados da PAM de 2001, da seguinte forma: Alto Teles Pires (MR-1), Sinop (MR-2), Colíder (MR-3), Canarana (MR-4), Paranatinga (MR-5), Parecis (MR-6), Arinos (MR-7), Alta Floresta (MR-8), Norte Araguaia (MR-9), Aripuanã (MR10), Alto Paraguai (MR-11), Tangará da Serra (MR-12), Primavera do Leste (MR-13), Rondonópolis (MR-14), Jauru (MR-15), Tesouro (MR-16), Médio Araguaia (MR-17), Alto Pantanal (MR-18), Alto Guaporé (MR-19), Alto Araguaia (MR-20), Cuiabá (MR21), Rosário Oeste (MR-22). O IBGE agrupa em microrregiões homogêneas os municípios que, dentro do estado, apresentam as características socioeconômicas e edafo-climáticas semelhantes.

Gonçalves \& Souza (2001), em estudo que buscava caracterizar o Vale do Ribeira, citam a importância de se considerar a heterogeneidade da região em que se irá caracterizar; os autores afirmaram que análises genéricas em um ambiente de complexidade poderá indicar maior profundidade das disparidades regionais. Apesar dos autores levarem em conta primordialmente a homogeneidade das condições socioeconômicas locais, vale considerar que a fidedigna caracterização das regiões de estudo refletirá as variadas combinações de sistemas produtivos que ora são aplicados, salientando que mesmo intra-região pode-se encontrar sistemas de produção divergentes, dada a característica de atomização da produção e da diferenciação do nível tecnológico adotado pelos produtores.

O Estado do Mato Grosso situa-se na região Centro-Oeste brasileira, abrange uma superfície de 903.386,1 km², correspondendo a 10,61\% do território nacional (Anuário Estatístico do Brasil, 2002). O estado é formado por 126 municípios e faz divisa ao norte com os estados do Pará e Amazonas, ao leste com Tocantins e Goiás, ao sul com Mato Grosso do Sul e faz a oeste, fronteira com a Bolívia e divisa com Rondônia.

\subsection{Levantamento dos dados}

Os dados de área, produção e produtividade utilizados no estudo de "shiftshare” foram extraídos da PAM. O período analisado compreende os anos de 1979 a 
2001. As informações de área colhida são uma aproximação dos dados de área plantada. Os dados são transformados em médias aritméticas trienais móveis, com o objetivo de amenizar as possíveis interferências climáticas (anos anormais) e/ou econômicas que afetam a produção agrícola. Centraliza-se a análise nos anos de 1980, 1985, 1990, 1995 e 2000 para efeito do estudo do crescimento da produção orizícola no Mato Grosso.

Essa segmentação quinqüenal foi realizada devido aos seguintes fatores: a divisão do Estado do Mato Grosso em 1978, iniciando a análise a partir de 1980. Nakano (1992) argumenta que o crédito rural abundante existente até meados de década de 1980 permitiu a capitalização, modernização da agricultura e incorporação de novas áreas no Centro-Oeste. Verifica-se na Figura 3 a redução do volume de crédito rural até o ano de 1984 e há novamente aumento do volume de crédito rural em 1985 e 1986 para posterior redução. A razão em se escolher o ano de 1985 como marco no estudo está relacionado ao fato de que a partir da segunda metade da década de 80 foram sendo implantadas reformas estruturais liberalizantes, o desmantelamento de órgãos, esfacelamento dos instrumentos de intervenção e eliminação de políticas discricionárias, principalmente para o arroz (Dias \& Amaral, 1999; Baer, 2002). A década de 90 foi dividida em dois subperíodos: 1990 a 1995 e 1995 a 2000. O primeiro subperíodo foi decorrente da abertura comercial brasileira, do desmonte das instituições e instrumentos que nortearam a política agrícola e do baixo volume de crédito rural disponível. O segundo subperíodo é marcado pelo início do Plano Real (Belik, 1998).

As culturas estudadas são: arroz, soja, milho e algodão, selecionadas, conforme comentado anteriormente, pela competição existente por área agricultável no processo de tomada de decisão do produtor.

As informações dos preços recebidos pelos produtores do Mato Grosso foram levantadas da Fundação Getúlio Vargas - FGV e consistem em dados mensais, envolvendo os anos de 1979 a 2001, deflacionados para setembro de 2003 pelo Índice Geral de Preços - Disponibilidade Interna (IGP-DI), calculado pela FGV. Calculou-se uma média aritmética dos preços reais e manteve-se o preço fixo, pois o que se deseja na análise do crescimento do valor da produção das culturas de interesse (algodão, arroz, 
milho e soja) na microrregião e no estado eram as modificações ocorridas na produção agrícola.

Os dados para o estudo da inserção do arroz no Centro-Oeste brasileiro foram obtidos por meio da aplicação de questionários junto a produtores e agroindústrias de alguns municípios do Mato Grosso (Anexos A e B), conforme citado anteriormente.

\subsection{Descrição do modelo "Shift-Share"}

O modelo "shift-share", também conhecido como diferencial-estrutural, foi utilizado para medir as fontes de crescimento das culturas em questão no Estado do Mato Grosso e em suas 22 microrregiões.

O modelo visa explicar o comportamento da produção agrícola mediante a decomposição dos fatores responsáveis pela variação da produção. O crescimento das culturas é explicado por dois componentes: o estrutural, que está ligado à composição setorial das atividades da região, e o diferencial, relacionado às vantagens locacionais comparativas. Consideram-se quatro efeitos na variação da produção:
a) efeito área - EA;
b) efeito rendimento ou produtividade - ER;
c) efeito localização geográfica - EL;
d) efeito composição - EC.

Os quatro efeitos estão inclusos na análise do crescimento da produção do conjunto de culturas no estado. Quanto à análise individual de cada cultura, pode-se obter os efeitos área, rendimento e localização geográfica. O estudo do crescimento do valor da produção das culturas em cada microrregião consiste nas variações dos efeitos área, rendimento e composição da produção. A análise não considera as interações entre as fontes de crescimento (Moreira, 1996). 
Detalhando os efeitos explicativos da variação da produção, tem-se que o efeito área indica mudanças na produção provenientes de alterações na área cultivada (usando a área colhida como aproximação), supondo que os demais efeitos permaneçam constantes no decorrer do tempo. Dessa forma, um aumento na produção é atribuído à incorporação de novas áreas, indicando um uso extensivo do solo.

O efeito rendimento mensura a variação na produção decorrente da variação da produtividade, dados os outros efeitos inalterados. A variação no rendimento pode refletir mudanças tecnológicas pela adoção de novos insumos, técnicas de produção e melhoria do capital humano. Silva (1984) afirma que a mensuração ideal do progresso tecnológico seria o ganho de produtividade total, porém a inexistência de dados do uso dos fatores de produção torna a tarefa difícil, daí recorre-se à produtividade da terra, utilizando a produtividade da cultura como uma "proxy” das mudanças tecnológicas. Vera Filho \& Tollini (1979) afirmam que o rendimento não está necessariamente associado ao progresso tecnológico, pois, em um dado momento, produtores que obtêm maior produtividade podem estar empregando um processo produtivo menos eficiente que produtores cuja produtividade é menor. Alguns autores ${ }^{2}$ consideram a produtividade como uma importante variável na explicação dos ganhos do setor agrícola.

O efeito localização geográfica reflete as alterações observadas na produção advindas das vantagens locacionais, ou seja, decorrentes da mudança na localização das culturas entre as microrregiões estudadas, mantendo-se os demais componentes constantes. Segundo Curi (1997), no modelo "shift-share", as vantagens locacionais de uma cultura são positivas quando a expansão da área cultivada em algumas regiões for suficiente para contrabalancear a estabilidade ou retração nas demais regiões e for acompanhada de maiores produtividades. No caso de redução generalizada da área cultivada, o efeito ainda será positivo se esta redução ocorrer de forma menos que proporcional nas regiões de maiores ganhos relativos no rendimento.

\footnotetext{
${ }^{2}$ Fassarella (1987), Yokoyama (1988), Gasques \& Verde (1990), Moreira (1996), Alves (2000) etc.
} 
O efeito composição diz respeito as variações na produção decorrentes de alterações na estrutura produtiva, ou seja, traduz a mudança na produção relativa à proporção da área total cultivada com as diversas culturas, supondo que o rendimento e a área total cultivada permaneçam constantes. Associa-se o efeito composição à rentabilidade por área, uma vez que determinada cultura mais rentável pode se expandir em detrimento de outra cultura menos rentável, havendo um movimento de substituição entre as culturas.

\subsubsection{Variáveis utilizadas}

Objetivando simplificar a leitura, dispõem-se neste item as variáveis utilizadas no estudo de "shift-share” da orizicultura mato-grossense.

O subíndice “c” indica a cultura estudada e varia de 1 a n, com c assumindo os valores $\{1,2,3,4\}$, representando respectivamente as culturas do arroz, soja, milho e algodão, para o estado e cada microrregião.

O subíndice “m” representa a microrregião de estudo, variando de 1 a $\mathrm{k}$ (com m variando de 1 a 22).

O subíndice “t” define o período de tempo. O período inicial é representado por "i” e o período final por “f”.

As variáveis seguem abaixo:

$Q_{c t} \quad$ é a quantidade produzida da c-ésima cultura no estado, no período t;

$A_{c m t}$ representa a área total cultivada com a c-ésima cultura, na m-ésima microrregião, no período t;

$A_{c t}$ é a área total cultivada com a c-ésima cultura no estado, no período t;

$A_{m t} \quad$ é a área total cultivada das culturas, em hectares, na m-ésima microrregião do estado, no período t; 
A corresponde à área total cultivada com as culturas, em hectares, no estado, no período t;

$V_{t} \quad$ é o valor da produção das culturas no estado, em reais, no período t;

$V_{m t}$ equivale ao valor da produção das culturas na m-ésima microrregião do estado, em reais, no período t;

$P_{c} \quad$ é o preço médio pago ao produtor por unidade do produto da c-ésima cultura no estado;

$R_{c m t}$ é o rendimento da c-ésima cultura, na m-ésima microrregião do estado, no período t;

$\alpha_{m t}$ representa a proporção da área total cultivada na m-ésima microrregião na área total cultivada no estado ( $A_{m t} / A_{t}$ ), no período t;

$\beta_{c m t}$ é a proporção da área total cultivada com a c-ésima cultura na m-ésima microrregião, na área total na m-ésima microrregião do estado $\left(A_{c m t} / A_{m t}\right)$, no período t;

$\gamma_{c m t}$ é a proporção da área total cultivada com a c-ésima cultura na m-ésima microrregião, na área cultivada da c-ésima cultura no estado $\left(A_{c m t} / A_{c t}\right)$, no período t;

$\lambda$ é o coeficiente que mensura a modificação na área total cultivada das culturas entre o período inicial e final ( $A_{f} / A_{i}$ ). 


\subsubsection{Descrição do modelo matemático}

Descreve-se a formulação matemática do modelo "shift-share" para os níveis em que a análise foi realizada. O presente item será subdividido em análise por cultura no estado, análise do conjunto de culturas em cada microrregião e análise do conjunto de culturas no estado. Destaca-se na análise individual por cultura no estado, a decomposição da área cultivada das mesmas em efeito escala e substituição para averiguar a expansão ou retração da área e os movimentos de substituição de uma lavoura por outra. Todos os dados foram calculados em planilhas do programa Microsoft Excel 2001.

\subsubsection{Análise individual das culturas no Estado do Mato Grosso}

Ao analisar cada lavoura no estado, verificam-se os efeitos área, rendimento e localização geográfica.

A quantidade produzida no estado da c-ésima cultura, no período t, é expressa pela seguinte equação:

$$
Q_{c t}=\sum_{m=1}^{k}\left(A_{c m t} R_{c m t}\right)
$$

Para determinar a quantidade produzida no estado da c-ésima cultura, no período inicial "i", utiliza-se a equação (1) para os dados relativos ao período inicial.

$$
Q_{c i}=\sum_{m=1}^{k}\left(A_{c m i} R_{c m i}\right)=\sum_{m=1}^{k}\left(\gamma_{c m i} A_{c i} R_{c m i}\right)
$$


Se $A_{c m f}$ e $R_{c m f}$ são, respectivamente, área cultivada e rendimento da c-ésima cultura na m-ésima microrregião no período final ( $f$ ), então a quantidade produzida da c-ésima cultura no período final $\left(Q_{c f}\right)$ é definida por:

$$
Q_{c f}=\sum_{m=1}^{k}\left(A_{c m f} R_{c m f}\right)=\sum_{m=1}^{k}\left(\gamma_{c m f} A_{c f} R_{c m f}\right)
$$

Se, no período considerado, apenas a área total cultivada com a cultura no estado se alterar, a produção final $\left(Q_{c f}^{A}\right)$ será:

$$
Q_{c f}^{A}=\sum_{m=1}^{k}\left(\gamma_{c m i} A_{c f} R_{c m i}\right)
$$

No entanto, se a área e o rendimento variarem, permanecendo constantes a localização geográfica e a composição da produção, a quantidade produzida no período “f” $\left(Q_{c f}^{A R}\right)$ será:

$$
Q_{c f}^{A R}=\sum_{m=1}^{k}\left(\gamma_{c m i} A_{c f} R_{c m f}\right)
$$

E se, por último, variarem a localização geográfica, juntamente com a área e com o rendimento, a produção final será descrita por:

$$
Q_{c f}^{A R L}=\sum_{m=1}^{k}\left(\gamma_{c m f} A_{c f} R_{c m f}\right)=Q_{c f}
$$


Pode-se expressar a mudança total da quantidade produzida da c-ésima cultura do período inicial “i” para o período final “f” $\left(Q_{c f}-Q_{c i}\right)$ pela equação:

$$
Q_{c f}-Q_{c i}=\sum_{m=1}^{k} \gamma_{c m f} A_{c f} R_{c m f}-\sum_{m=1}^{k} \gamma_{c m i} A_{c i} R_{c m i}
$$

que também pode ser expressa da seguinte forma:

$$
Q_{c f}-Q_{c i}=\left(Q_{c f}^{A}-Q_{c i}\right)+\left(Q_{c f}^{A R}-Q_{c f}^{A}\right)+\left(Q_{c f}-Q_{c f}^{A R}\right)
$$

onde:

$Q_{c f}-Q_{c i}$ é a variação total da produção da c-ésima cultura entre o período inicial e final;

$Q_{c f}^{A}-Q_{c i}$ é a variação total da quantidade produzida da c-ésima cultura entre o período inicial e final, quando apenas a área cultivada se altera, sendo denominada de efeito área (EA);

$Q_{c f}^{A R}-Q_{c f}^{A}$ é a variação total da produção da c-ésima cultura entre “i” e “f”, quando o rendimento varia e as outras variáveis permanecem constantes, sendo chamada de efeito rendimento (ER);

$Q_{c f}-Q_{c f}^{A R}$ é a variação total da quantidade produzida da c-ésima cultura entre os períodos “i” e “f”, devido à mudança da localização geográfica, mantendo constantes as outras variáveis, sendo conhecido por efeito localização geográfica (EL). 
Resgatando as equações (5) e (6), verifica-se que o efeito localização geográfica é dado por:

$$
\begin{aligned}
E L= & \sum_{m=1}^{k}\left(\gamma_{c m f} A_{c f} R_{c m f}\right)-\sum_{m=1}^{k}\left(\gamma_{c m i} A_{c f} R_{c m f}\right) \\
& =A_{c f}\left(\sum_{m=1}^{k} \gamma_{c m f} R_{c m f}-\sum_{m=1}^{k} \gamma_{c m i} R_{c m f}\right)
\end{aligned}
$$

A expressão entre parênteses consiste na diferença entre duas médias ponderadas dos rendimentos $\left(R_{c m f}\right)$, variando o fator de ponderação. A média ponderada torna-se maior quando o peso dos rendimentos mais altos forem maiores. Logo, o EL é positivo se aumentar a participação das microrregiões homogêneas onde o rendimento no período “f” é mais alto (Yokoyama, 1988).

\subsection{Formulação matemática para apresentação dos resultados}

Utiliza-se a metodologia proposta por Igreja (1987) para a apresentação dos resultados na forma de taxas anuais de crescimento da produção. Tal metodologia foi utilizada por Yokoyama (1988), Cardoso (1995), Moreira (1996) e Alves (2000).

Os valores dos efeitos isolados encontrados são apresentados na forma de taxas anuais de crescimento, sendo expressos individualmente como uma percentagem da mudança total na produção.

Dividindo-se ambos os lados da equação (8) por ( $Q_{c f}-Q_{c i}$ ), tem-se a identidade:

$$
1 \equiv \frac{\left(Q_{c f}^{A}-Q_{c i}\right)}{\left(Q_{c f}-Q_{c i}\right)}+\frac{\left(Q_{c f}^{A R}-Q_{c f}^{A}\right)}{\left(Q_{c f}-Q_{c i}\right)}+\frac{\left(Q_{c f}-Q_{c f}^{A R}\right)}{\left(Q_{c f}-Q_{c i}\right)}
$$


Multiplicando-se ambos os lados da identidade (9) por:

$$
r=\left(\sqrt[f]{\frac{Q_{c f}}{Q_{c i}}}-1\right) \cdot 100
$$

onde $f$ corresponde à quantidade de anos do período em análise e $r$ é a taxa anual média de variação da produção da c-ésima cultura, em porcentagem, obtém-se a seguinte expressão:

$$
r=\frac{\left(Q_{c f}^{A}-Q_{c i}\right)}{\left(Q_{c f}-Q_{c i}\right)} r+\frac{\left(Q_{c f}^{A R}-Q_{c f}^{A}\right)}{\left(Q_{c f}-Q_{c i}\right)} r+\frac{\left(Q_{c f}-Q_{c f}^{A R}\right)}{\left(Q_{c f}-Q_{c i}\right)} r
$$

na qual:

$$
\left(Q_{c f}^{A}-Q_{c i}\right)
$$

$\frac{\left(Q_{c f}-Q_{c i}\right)}{r}$ é o efeito área (EA), expresso em taxa de crescimento ao ano, em porcentagem;

$\frac{\left(Q_{c f}^{A R}-Q_{c f}^{A}\right)}{\left(Q_{c f}-Q_{c i}\right)} r$ é o efeito rendimento (ER), expresso em taxa de crescimento ao ano, em porcentagem;

$\frac{\left(Q_{c f}-Q_{c f}^{A R}\right)}{\left(Q_{c f}-Q_{c i}\right)} r$ é o efeito localização geográfica (EL), expresso em taxa de crescimento ao ano, em porcentagem. 


\subsection{Decomposição do efeito área em efeitos escala e substituição}

Utiliza-se o modelo desenvolvido por Zockun (1978) para analisar as alterações na composição da área cultivada no estado e em suas microrregiões nos períodos distintos. $\mathrm{O}$ autor pressupõe que a área cultivada de determinada cultura em um determinado período, dentro do sistema de produção, pode ser modificada por dois fatores ou efeitos:

a) escala: é a variação da área total das culturas estudadas;

b) substituição: identifica a variação da participação de cada cultura dentro do sistema de produção. Pode ser positivo, indicando que no período analisado a cultura considerada se expandiu, ganhando área de outras culturas, e aumentando sua participação. Em contrapartida, o efeito também pode ser negativo, indicando que no período considerado uma determinada cultura está sendo substituída por outra dentro do sistema, diminuindo sua participação.

A variação da área ocupada por determinada cultura no sistema de produção é expressa por:

$$
\left(A_{c f}-A_{c i}\right)
$$

Considerando $\lambda$ como o coeficiente que mede a modificação do tamanho do sistema, a variação da área ocupada do sistema pode ser decomposta no efeito escala e no efeito substituição:

$$
\begin{aligned}
& \left(\lambda A_{c i}-A_{c i}\right) \text { é o efeito escala (EE); } \\
& \left(A_{c f}-\lambda A_{c i}\right) \text { é o efeito substituição (ES). }
\end{aligned}
$$

Ou seja, 


$$
\left(A_{c f}-A_{c i}\right)=\left(\lambda A_{c i}-A_{c i}\right)+\left(A_{c f}-\lambda A_{c i}\right)
$$

Verifica-se dentro do sistema de produção o efeito escala, visto que o somatório do efeito substituição é nulo, ou seja:

$$
\sum_{c=1}^{n}\left(A_{c f}-\lambda A_{c i}\right)=0
$$

Esses efeitos são apresentados na forma de taxas anuais de crescimento, seguindo os mesmos procedimentos da transformação anteriormente demonstrada no item 4.3.2.1.1.. Isso significa que, dividindo-se ambos os lados da equação (13) por $\left(A_{c f}-A_{c i}\right)$ tem-se:

$$
1 \equiv \frac{\left(\lambda A_{c i}-A_{c i}\right)}{\left(A_{c f}-A_{c i}\right)}+\frac{\left(A_{c f}-\lambda A_{c i}\right)}{\left(A_{c f}-A_{c i}\right)}
$$

Multiplicando-se ambos os lados da identidade (15) pelo efeito área (EA), definido anteriormente, tem-se:

$$
E A=\frac{\left(\lambda A_{c i}-A_{c i}\right)}{\left(A_{c f}-A_{c i}\right)} E A+\frac{\left(A_{c f}-\lambda A_{c i}\right)}{\left(A_{c f}-A_{c i}\right)} E A
$$

onde:

$$
\frac{\left(\lambda A_{c i}-A_{c i}\right)}{\left(A_{c f}-A_{c i}\right)} E A \quad \text { é o efeito escala, em porcentagem ao ano; }
$$


$\frac{\left(A_{c f}-\lambda A_{c i}\right)}{\left(A_{c f}-A_{c i}\right)} E A \quad$ é o efeito substituição, em porcentagem ao ano.

O modelo pressupõe que as culturas que cederam área o fizeram proporcionalmente para todas as culturas que expandiram suas áreas, podendo-se determinar a parcela das áreas cedidas pelas culturas (efeito substituição negativo) que se destinou à produção das culturas que tiveram efeito substituição positivo.

\subsubsection{Análise do conjunto de culturas por microrregião}

No estudo do crescimento do valor da produção do conjunto de culturas de cada microrregião, o efeito localização geográfica torna-se nulo, obtendo-se o efeito área, efeito rendimento e o efeito composição. Desta maneira, o valor da produção no período inicial para uma dada microrregião é dado por:

$$
V_{m i}=\sum_{c=1}^{n} A_{c m i} R_{c m i} P_{c}=\sum_{c=1}^{n} \beta_{c m i} A_{m i} R_{c m i} P_{c}
$$

e no período final, o valor da produção é:

$$
V_{m f}=\sum_{c=1}^{n} A_{c m f} R_{c m f} P_{c}=\sum_{c=1}^{n} \beta_{c m f} A_{m f} R_{c m f} P_{c}
$$

Torna-se necessária a utilização da variável preço $\left(P_{c}\right)$ como redutora a unidade comum, pois, fixando o preço, verifica-se somente as modificações decorrentes da produção agrícola.

Se, no período considerado, apenas a área cultivada se alterar, o valor da produção em "f” será: 


$$
V_{m f}^{A}=\sum_{c=1}^{n} \beta_{c m i} A_{m f} R_{c m i} P_{c}
$$

Modificando o rendimento e a área de cada cultura, em relação a situação inicial, e mantendo constantes as proporções das áreas, o valor da produção no período final será:

$$
V_{m f}^{A R}=\sum_{c=1}^{n} \beta_{c m i} A_{m f} R_{c m f} P_{c}
$$

E se as participações de cada lavoura na área cultivada também forem alteradas, tem-se:

$$
V_{m f}^{A R C}=\sum_{c=1}^{n} \beta_{c m f} A_{m f} R_{c m f} P_{c}=V_{m f}
$$

A mudança total no valor da produção de dada microrregião, com preço constante é definida por:

$$
V_{m f}-V_{m i}=\sum_{c=1}^{n} \beta_{c m f} A_{m f} R_{c m f} P_{c}-\sum_{c=1}^{n} \beta_{c m i} A_{m i} R_{c m i} P_{c}
$$

ou por:

$$
V_{m f}-V_{m i}=\left(V_{m f}^{A}-V_{m i}\right)+\left(V_{m f}^{A R}-V_{m f}^{A}\right)+\left(V_{m f}-V_{m f}^{A R}\right)
$$

onde: 
$V_{m f}-V_{m i}$ é a variação total no valor da produção da m-ésima microrregião entre o período inicial e final;

$V_{m f}^{A}-V_{m i} \quad$ é o efeito área (EA);

$V_{m f}^{A R}-V_{m f}^{A} \quad$ é o efeito rendimento (ER);

$V_{m f}-V_{m f}^{A R} \quad$ é o efeito composição do produto (EC);

Relembrando as equações (22) e (23), verifica-se que o EC é dado por:

$$
\begin{aligned}
E C & =\sum_{c=1}^{n} \beta_{c m f} A_{m f} R_{c m f} P_{c}-\sum_{c=1}^{n} \beta_{c m i} A_{m i} R_{c m f} P_{c} \\
& =A_{m f}\left(\sum_{c=1}^{n} \beta_{c m f} R_{c m f} P_{c}-\sum_{c=1}^{n} \beta_{c m i} R_{c m f} P_{c}\right)
\end{aligned}
$$

Os termos entre parênteses compreendem a diferença entre duas médias ponderadas das variáveis rendimento e preço, mudando o fator de ponderação $\beta_{c m i}$ para $\beta_{c m f}$. A média ponderada será maior quando os pesos forem maiores nas regiões onde as variáveis rendimento e preço também são maiores. Portanto, o EC é positivo se aumentar a participação das culturas com alto valor do produto $R_{c m f} P_{c}$, isto é, lavouras com alto valor da produção por unidade de área (Yokoyama, 1988).

Utilizam-se também, para apresentação dos resultados, as taxas anuais de crescimento, executando-se o mesmo procedimento demonstrado no item 4.3.2.1.1.

\subsubsection{Análise do conjunto de culturas no estado}

Nesta análise são observados os quatro tipos de efeitos considerados para o crescimento da produção. Utiliza-se, também nesta etapa, o preço dos produtos como 
redutor a uma base comum, pois está se analisando a produção agregada das diferentes culturas.

O valor da produção estadual agregada no período inicial é definido por:

$$
V_{i}=\sum_{m=1}^{k} \sum_{c=1}^{n} \beta_{c m i} \alpha_{m i} A_{i} R_{c m i} P_{c}
$$

Da mesma maneira, calcula-se o valor da produção estadual agregada para o período final.

$$
V_{f}=\sum_{m=1}^{k} \sum_{c=1}^{n} \beta_{c m f} \alpha_{m f} A_{f} R_{c m f} P_{c}
$$

Caso a área total cultivada se altere, o valor da produção agregada estadual será dado por:

$$
V_{f}^{A}=\sum_{m=1}^{k} \sum_{c=1}^{n} \beta_{c m i} \alpha_{m i} A_{f} R_{c m i} P_{c}
$$

Se o rendimento das culturas em cada microrregião variar, juntamente com a área total cultivada, o valor da produção no período final será:

$$
V_{f}^{A R}=\sum_{m=1}^{k} \sum_{c=1}^{n} \beta_{c m i} \alpha_{m i} A_{f} R_{c m f} P_{c}
$$

Modificando também a participação de cada microrregião na área cultivada (localização geográfica), juntamente com a área e o rendimento, e mantendo constante a 
composição do produto em cada microrregião, o valor da produção do estado no período final será:

$$
V_{f}^{A R L}=\sum_{m=1}^{k} \sum_{c=1}^{n} \beta_{c m i} \alpha_{m f} A_{f} R_{c m f} P_{c}
$$

E por último, quando inclusive se altera a composição da produção, o valor da produção é dado por:

$$
V_{f}^{A R L C}=\sum_{m=1}^{k} \sum_{c=1}^{n} \beta_{c m f} \alpha_{m f} A_{f} R_{c m f} P_{c}=V_{f}
$$

A mudança total observada no valor da produção agregada no estado, no período em estudo (“i” a “f”), é dada por:

$$
V_{f}-V_{i}=\sum_{m=1 c=1}^{k} \sum_{c m f}^{n} \beta_{c m f} \alpha_{m f} A_{f} R_{c m f} P_{c}-\sum_{m=1 c=1}^{k} \sum_{c m i}^{n} \beta_{c m i} \alpha_{m i} A_{i} R_{c m i} P_{c}
$$

A equação ainda pode ser decomposta isolando as causas da variação.

$$
V_{f}-V_{i}=\left(V_{f}^{A}-V_{i}\right)+\left(V_{f}^{A R}-V_{f}^{A}\right)+\left(V_{f}^{A R L}-V_{f}^{A R}\right)+\left(V_{f}-V_{f}^{A R L}\right)
$$

onde:

$$
\begin{array}{ll}
V_{f}-V_{i} & \text { equivale à variação total do valor da produção entre o } \\
& \text { período inicial (i) e o final (f); } \\
V_{f}^{A}-V_{i} & \text { é o efeito área (EA); } \\
V_{f}^{A R}-V_{f}^{A} & \text { representa o efeito rendimento (ER); }
\end{array}
$$




$$
\begin{array}{lr}
V_{f}^{A R L}-V_{f}^{A R} & \text { é o efeito localização geográfica (EL); } \\
V_{f}-V_{f}^{A R L} & \text { é o efeito composição do produto (EC). }
\end{array}
$$

A transformação dos efeitos obtidos acima em taxas anuais de crescimento é semelhante à demonstrada no item 4.3.2.1.1.

\subsection{Sistema de produção}

A análise do comportamento da produção de arroz do Mato Grosso, bem como da forma como este está inserido na dinâmica de cultura do estado, será realizada por meio do estudo descritivo dos fenômenos observados através da aplicação de questionários junto a diversos agentes da cadeia produtiva.

Procurou-se agrupar as informações obtidas através dos questionários aplicados aos produtores de acordo com a localização geográfica dos municípios visitados no estado, levando em consideração que tal agregação também representa características similares do sistema produtivo empregado.

Conforme comentado anteriormente, os municípios visitados foram escolhidos por sua importância no setor e são integrantes das oito microrregiões mais produtivas do estado. Essas oito microrregiões foram agrupadas em quatro regiões: central, norte, leste e oeste. Os municípios que compõem a região norte são: Alta Floresta, Colíder, Guarantã do Norte, Matupá, Nova Canaã do Norte, Novo Mundo, Peixoto de Azevedo e Terra Nova do Norte. Vale salientar que geograficamente a microrregião de Sinop aparenta estar mais ao norte que ao centro, sendo uma região de transição, porém as características de produção dos municípios visitados nesta microrregião se assemelham às dos municípios da microrregião de Alto Teles Pires, considerada no estudo da descrição do sistema produtivo como região central.

No Apêndice 1 identifica-se a disposição das microrregiões do estado. Os municípios que compõem a região central são os seguintes: Cláudia, Lucas do Rio Verde, Nova Mutum, Nova Ubiratã, Santa Carmem, Sinop, Sorriso, Tapurah e Vera. A 
região leste é representada pelos seguintes municípios: Água Boa, Paranatinga, Primavera do Leste e Querência. Os municípios que representam a região oeste são: Campos de Júlio, Comodoro e Diamantino.

Foram realizadas 34 entrevistas previamente agendadas, envolvendo produtores com diferentes níveis tecnológicos de produção e técnicos especializados no setor (informantes da Conab no levantamento de safras, que também auxiliaram nas indicações dos produtores a serem entrevistados).

As entrevistas foram realizadas no período de 1 a 20 de abril de 2002 e seguiram o roteiro das perguntas descritas nos Anexos A e B. Os questionários apresentavam algumas diferenças conforme o nível de mercado atuante e buscavam compreender o sistema de produção e destino das vendas de arroz.

As perguntas do questionário ao produtor eram, em sua maioria, objetivas, mas com liberdade para o entrevistado comentar algo pertinente ao setor, ao contrário do questionário à agroindústria, no qual as perguntas eram majoritariamente subjetivas.

No questionário do produtor procurava-se identificar as culturas exploradas na propriedade, o tipo de posse da terra, a participação da orizicultura na renda da propriedade e se é realizada a prática agronômica de rotação de cultura. Objetivou ainda classificar o produtor quanto à atividade orizícola, ou seja, se o produtor se auto-define como profissional ou produtor esporádico de arroz, ou ainda se cultiva arroz por falta de melhor opção. Buscou-se entender quais eram os motivos que o levavam a cultivar arroz, e qual o principal papel da orizicultura na região, além dos motivos que o fazem decidir sobre o tamanho da área a ser cultivada. As variedades de arroz cultivadas e suas características, assim como os problemas que afetam a qualidade do grão, também foram questionados.

Procurou-se tornar a amostra dos produtores a mais abrangente possível, considerando as limitações de recursos.

O questionário da agroindústria buscou explorar o destino das vendas dos produtos, os problemas que afetam a qualidade da matéria-prima e as perspectivas de mercado. 
Gil (1999) afirma que a pesquisa descritiva tem como objetivo principal o detalhamento das características da população, fenômeno ou o estabelecimento de relações entre variáveis. Desta forma, a metodologia é aplicável ao estudo, pois visa a descrição das características da produção do arroz de terras altas no Mato Grosso. 


\section{RESULTADOS E DISCUSSÃO}

Este capítulo está dividido em duas partes principais: a primeira refere-se a descrição do sistema produtivo de arroz no Mato Grosso. A segunda trata da análise individual das culturas no estado e do conjunto de culturas nas microrregiões utilizando a metodologia “shift-share”, bem como dos movimentos de expansão e substituição das culturas.

\subsection{Descrição do sistema produtivo}

Conforme comentado anteriormente, agrupou-se as oito microrregiões em que foram realizadas as entrevistas aos agentes da cadeia orizícola, objetivando a descrição do sistema produtivo do arroz em competição com o algodão, milho e soja, em quatro grandes regiões: norte (Colíder e Alta Floresta), centro (Alto Teles Pires e Sinop), leste (Canarana, Paranatinga e Primavera do Leste) e oeste (Parecis). O agrupamento das microrregiões foi baseado em características semelhantes do sistema produtivo, de forma a gerar resultados menos genéricos.

De maneira geral, a produção do cereal na região norte do Mato Grosso interage em maior grau com a pecuária, com o seu uso voltado à recuperação de pastagens e abertura de áreas. A orizicultura da região central do Mato Grosso está voltada para abertura de áreas e, em menor intensidade, para rotação de cultura, especialmente, com a soja. Observa-se, na região leste, uma certa contradição em relação à orizicultura, pois há produtores realizando inovações, como plantio direto e irrigação sob pivô central, porém alguns agentes responsáveis pelo armazenamento e secagem estão se afastando da atividade e vislumbrando bom mercado para a cultura do algodão e 
fortalecimento dos mercados da soja e do milho. A região oeste mostrou-se a menos desenvolvida no cultivo do arroz, pela falta de infra-estrutura observada em alguns municípios.

De acordo com o observado por Villar \& Ferreira (2002), o caráter de substituição de culturas e também de recuperação de pastos imprime uma grande variabilidade na área e na produção de arroz do estado, como pode ser visualizado na Tabela 9 e 10. Constatou-se que a maioria dos produtores planta arroz esporadicamente, refletindo na grande variação da área plantada e produção obtida.

Essa grande variabilidade na quantidade produzida resulta em dificuldades de planejamento para toda a cadeia produtiva, principalmente para o abastecimento das agroindústrias já instaladas na região e constitui-se em um fator de risco para empresas que pretendem se instalar no estado. As Tabelas 9 e 10 apresentam, respectivamente, a área e a produção de arroz nas 10 principais microrregiões de cultivo do cereal. Visualiza-se, no Apêndice 2, as séries de dados de área e rendimento utilizadas no estudo "shift-share" e, no Apêndice 3, visualiza-se a memória de cálculo.

Tabela 9. Área colhida de arroz (em ha) das 10 maiores microrregiões cultivadoras de arroz do Mato Grosso, de 1996 a 2001.

\begin{tabular}{cccccccc}
\hline Microrregião & 1996 & 1997 & 1998 & 1999 & 2000 & 2001 & Tx. Cresc.* $^{*}$ \\
\hline Alto Teles Pires & 105.575 & 75.680 & 85.370 & 165.157 & 168.796 & 101.920 & 8,6 \\
Sinop & 16.326 & 11.936 & 18.196 & 48.715 & 67.325 & 61.086 & 44,0 \\
Paranatinga & 45.208 & 33.640 & 35.980 & 60.599 & 70.174 & 49.593 & 9,5 \\
Colíder & 19.697 & 19.360 & 26.622 & 52.716 & 71.830 & 42.000 & 27,1 \\
Canarana & 59.848 & 45.595 & 34.558 & 59.090 & 58.778 & 38.361 & $-2,6$ \\
Parecis & 53.750 & 55.421 & 49.200 & 145.450 & 90.454 & 29.515 & $-1,3$ \\
Norte Araguaia & 14.785 & 13.650 & 14.475 & 20.852 & 23.512 & 27.116 & 15,5 \\
Arinos & 9.960 & 10.152 & 17.112 & 19.783 & 22.200 & 21.517 & 19,9 \\
Alta Floresta & 17.150 & 12.100 & 19.900 & 28.060 & 34.950 & 17.100 & 10,6 \\
Aripuanã & 7.280 & 12.050 & 8.960 & 15.594 & 16.020 & 13.429 & 13,6 \\
Mato Grosso & 429.086 & 355.231 & 364.148 & 726.682 & 698.518 & 450.413 & 8,8 \\
\hline
\end{tabular}

Fonte: IBGE (2003d)

* taxa de crescimento anual, em porcentagem, baseada em regressão econométrica 
A Tabela 9 mostra grandes aumentos em área de arroz na maioria das microrregiões selecionadas, exceção feita para Canarana e para Parecis. A microrregião de Sinop cresceu a uma taxa média anual de $44 \%$. O mais interessante de se observar é a grande variação na área colhida (aproximação da área cultivada) em um pequeno intervalo de tempo; por exemplo, em Alto Teles Pires, há um aumento de 123\% na área entre 1997 e 2000, para se ter uma brusca queda, de aproximadamente 40\%, entre as safras 2000 e 2001, ocorrendo o mesmo em outras microrregiões. De maneira geral, percebe-se uma redução do plantio de 2000 para 2001, após um período de elevação de área plantada. A redução da área em 2001 foi em decorrência dos baixos preços ao produtor ocasionados pela alta produção na safra anterior e pelos estoques nacionais que eram suficientemente grandes para suprir a demanda na entressafra. A redução da área da safra 2000/01 foi observada em praticamente todo o Brasil, como pode ser visto na Tabela 5.

Tabela 10. Produção de arroz (em toneladas) das 10 principais microrregiões produtoras do Estado do Mato Grosso, de 1996 a 2001.

\begin{tabular}{cccccccc}
\hline Microrregião & 1996 & 1997 & 1998 & 1999 & 2000 & 2001 & Tx. Cresc.* \\
\hline Alto Teles Pires & 193.101 & 176.916 & 205.548 & 432.297 & 459.232 & 308.523 & 18,5 \\
Sinop & 39.781 & 31.195 & 51.775 & 129.468 & 202.845 & 188.845 & 50,6 \\
Colíder & 32.384 & 32.303 & 66.896 & 147.880 & 222.285 & 121.365 & 45,8 \\
Canarana & 89.513 & 92.179 & 61.331 & 116.212 & 147.422 & 92.412 & 6,5 \\
Paranatinga & 64.479 & 57.992 & 68.794 & 125.306 & 172.884 & 90.023 & 17,2 \\
Parecis & 94.475 & 115.964 & 106.560 & 352.877 & 238.583 & 71.389 & 5,8 \\
Arinos & 18.292 & 18.392 & 38.676 & 52.335 & 59.280 & 61.295 & 32,5 \\
Alta Floresta & 30.970 & 22.820 & 38.022 & 68.712 & 96.900 & 47.491 & 22,4 \\
Norte Araguaia & 21.833 & 18.022 & 20.253 & 32.127 & 39.882 & 47.470 & 21,2 \\
Aripuanã & 14.414 & 21.947 & 17.950 & 32.248 & 37.064 & 27.087 & 16,4 \\
Mato Grosso & 721.793 & 694.904 & 776.502 & 1.727 .339 & 1.851 .517 & 1.151 .816 & 19,0 \\
\hline
\end{tabular}

Fonte: IBGE (2003d)

* taxa de crescimento anual, em porcentagem, baseada em regressão econométrica 
Observa-se na Tabela 10 que todas as microrregiões tiveram a produção de arroz aumentada de 1996 a 2001. Observou-se, na microrregião de Parecis, a menor elevação na produção de arroz no período considerado. Isto se deve ao grande aumento ocorrido na área de algodão, milho e soja, em detrimento da área de arroz. O aumento da produção de arroz nas microrregiões de Canarana e Parecis foi baseado em maior produtividade. A produção sofreu uma grande queda na safra 2001, resultado da redução da área plantada em função das baixas cotações obtidas na safra anterior, conforme já discutido, (exceção feita às microrregiões de Arinos e Norte Araguaia, em que houve aumento da produção nos dois últimos anos). As microrregiões de Sinop e Colíder tiveram aumento de produção com taxas de crescimento de 50,6\% a.a. e 45,8\% a.a., respectivamente.

A variabilidade de área e produção de arroz, observada nas Tabelas 9 e 10, acaba afetando o desempenho das outras culturas, visto que são concorrentes em área. As Figuras 5 e 6 ilustram, a evolução da área plantada de algodão, arroz, milho e soja no Mato Grosso, respectivamente, em valores absolutos e na forma de índice para melhor visualização do crescimento das culturas. 


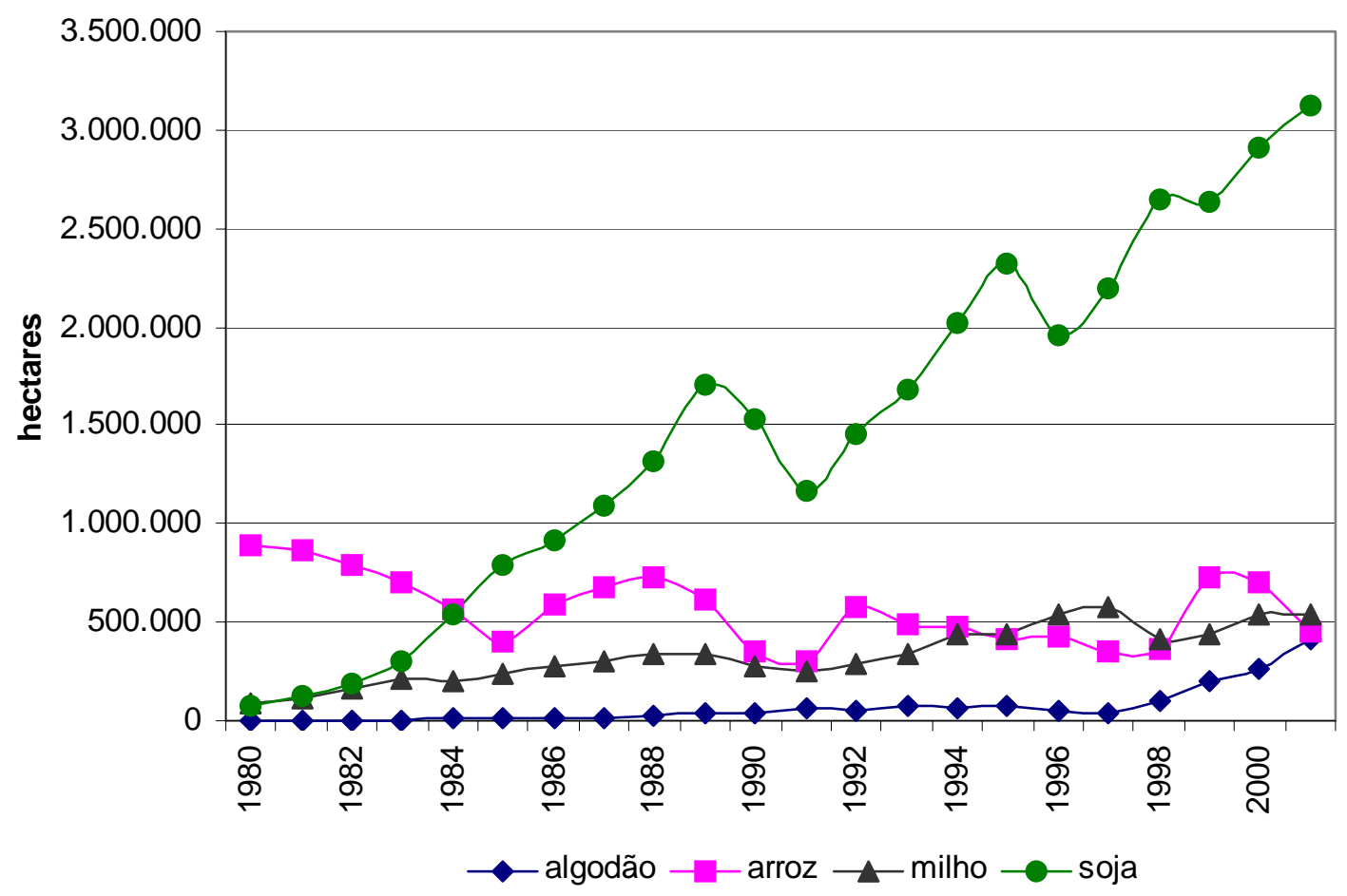

Figura 5 - Evolução da área mato-grossense de algodão, arroz, milho e soja. Fonte: IBGE (1980 - 2000)

Observa-se, na Figura 5, o grande aumento na área cultivada com soja no Mato Grosso a partir de 1985, ao mesmo tempo em que as culturas do algodão e do milho também apresentaram aumento de área. A área das culturas do algodão, do milho e da soja cresceram à taxa de $23 \%$ a.a., $7,2 \%$ a.a. e $15,7 \%$ a.a., respectivamente. Verifica-se que a orizicultura era a atividade com maior representatividade no estado, mas que ela vem sofrendo decréscimos em área ao longo do tempo. Essa redução apresenta-se com característica irregular, como um reflexo do objetivo de cultivo do arroz no estado, sendo uma atividade de caráter secundário, com finalidades de abertura de área, recuperação de pastos e, em menor grau, de rotação de cultura. A área de arroz decresceu à taxa anual de 2,4\%. 


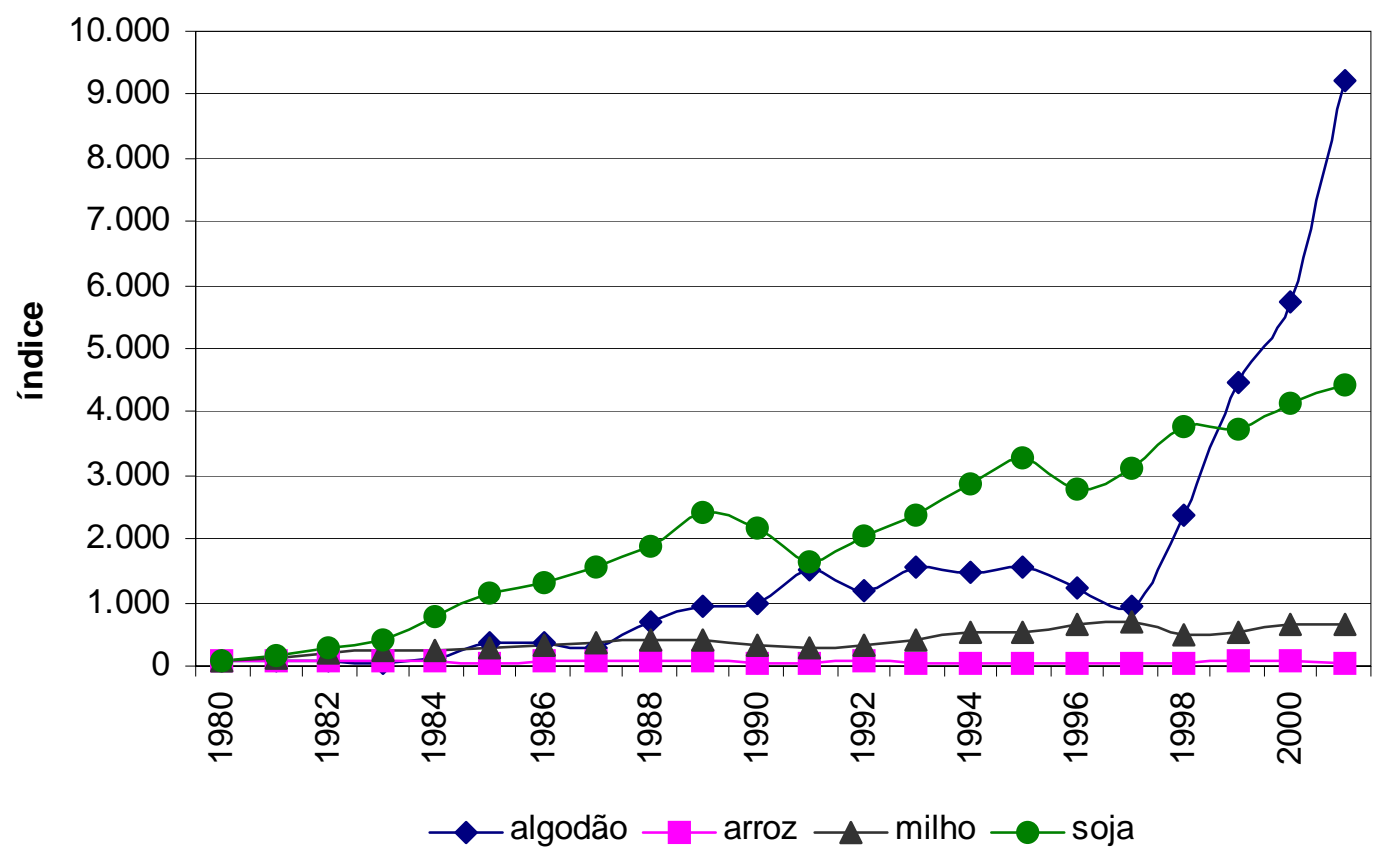

Figura 6 - Índice da evolução da área mato-grossense de algodão, arroz, milho e soja. Fonte: IBGE (1980 - 2000)

Percebe-se, na Figura 6, que a cultura do algodão obteve um grande crescimento em área a partir de 1998, mas essa atividade ainda é pouco expressiva em termos absolutos. Contudo, há uma tendência de que essa cultura ganhe mais área e se torne a segunda lavoura mais cultivada no estado, perdendo apenas para a soja, que também apresentou grande crescimento.

A Figura 7 retrata o comportamento da produção das culturas de interesse no estado e a Figura 8 identifica o crescimento da produção em forma de índice para melhor visualização do comportamento produtivo das culturas. 


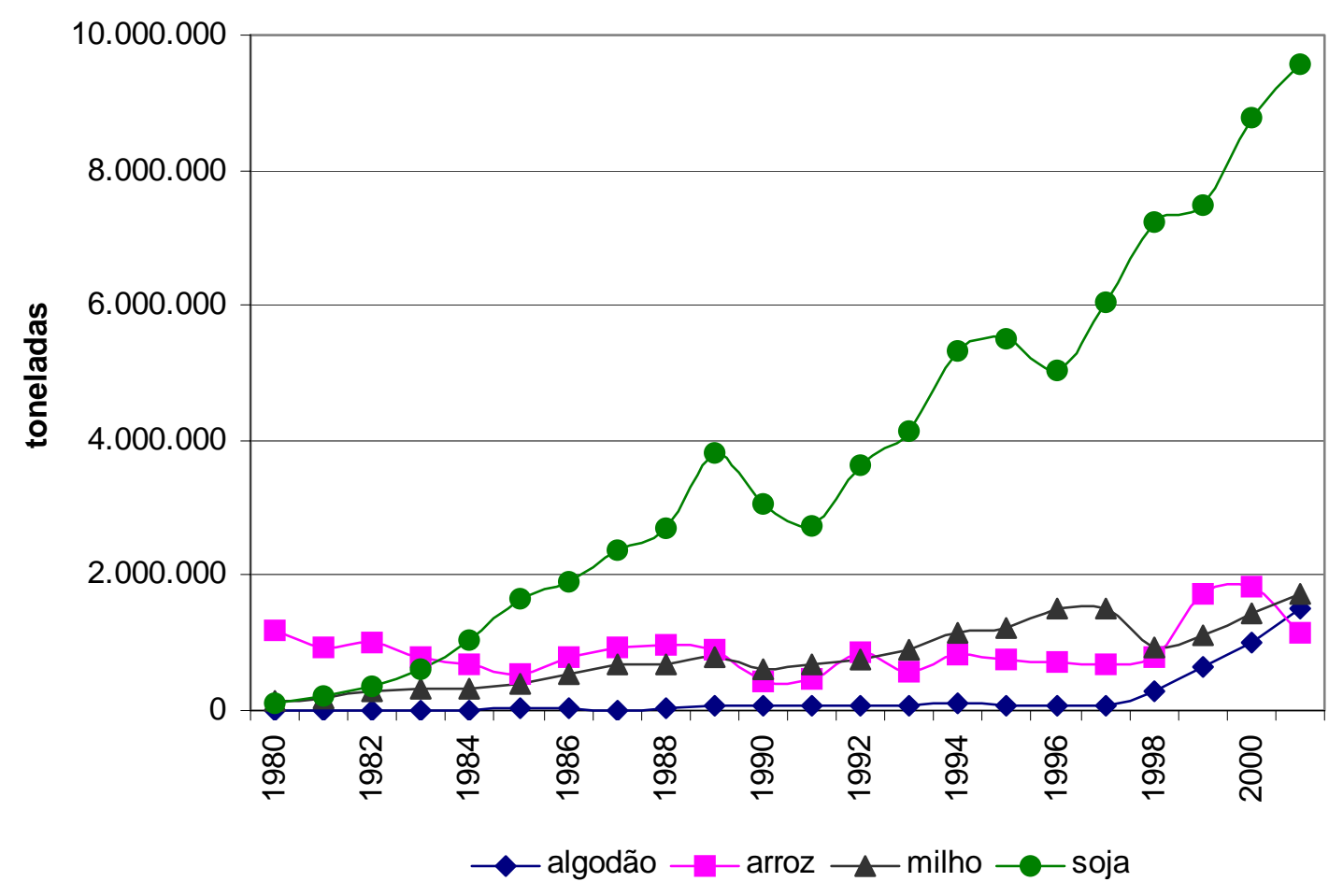

Figura 7 - Produção mato-grossense de algodão, arroz, milho e soja. Fonte: IBGE (1980 - 2000)

A Figura 7 demonstra que as culturas do algodão, milho e soja, obtiveram crescimento da produção ao longo do período considerado. O algodão cresceu à taxa de 29,8\% a.a., contribuindo para esse fato o crescimento da área e da produtividade, proporcionado pela adoção de tecnologia moderna, como o controle do bicudo, variedades mais produtivas e adaptadas ao clima local. A orizicultura, dentre as quatro culturas consideradas na análise, foi a de maior importância até 1983, sendo ultrapassada pela cultura da soja e em 2001 pela do milho e do algodão. Sua produção cresceu à taxa de 1,2\% a.a.. A produção de milho no estado cresceu à taxa de 10,5\% a.a. e a de soja cresceu à taxa média de $18,6 \%$ a.a.. 


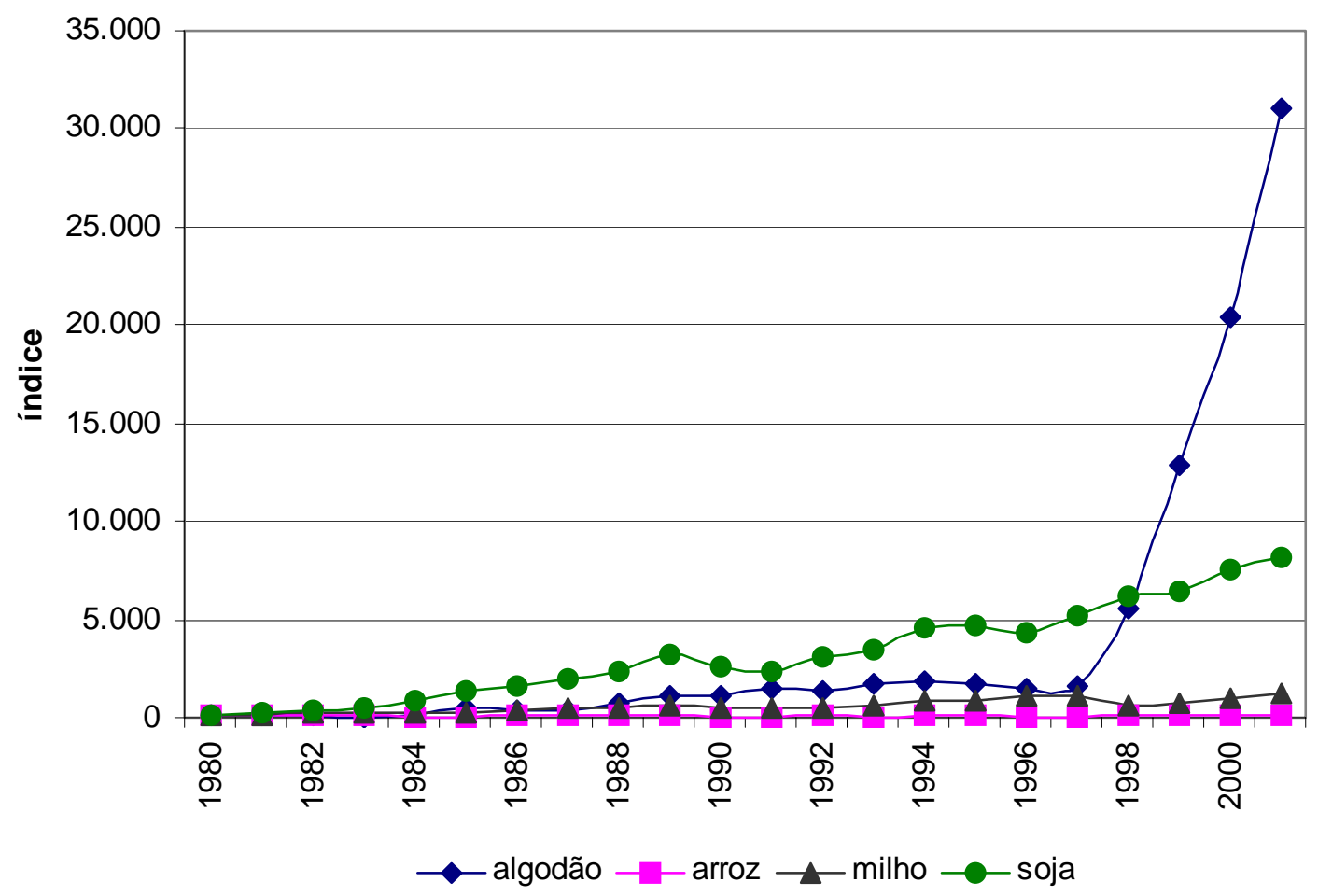

Figura 8 - Índice de evolução da produção mato-grossense de algodão, arroz, milho e soja.

Fonte: IBGE (1980 - 2000)

Destaca-se, na Figura 8, o grande aumento da produção mato-grossense de algodão a partir de 1998, crescendo 30.941\%, passando de 4.914 t em 1980 para 1.525.376 t em 2001.

Villar et al. (2002a) distinguem cinco dinâmicas de produção de arroz, a saber: a primeira consiste na exploração do arroz nas áreas de fronteira agrícola, nas áreas recém-desmatadas e de pastagens degradadas. A segunda representa a utilização do arroz em integração com a soja e o milho e, mais recentemente, com o algodão. A terceira diz respeito à substituição do arroz pela soja, a quarta dinâmica refere-se à substituição do arroz pelo milho e o algodão e a quinta refere-se à baixa intensidade de utilização das áreas agricultáveis. No entanto, pode-se resumir as cinco distintas dinâmicas de cultivo em três. (i) a exploração do arroz em áreas de fronteira agrícola e 
áreas recém-desmatadas para ceder espaço a outras culturas ou para a pecuária. (ii) o plantio do arroz integrado com a soja, milho e mais recentemente com o algodão e (iii) o plantio do arroz para recuperação de pastagens degradadas. Apesar dessa diferenciação em sistemas de cultivo, observa-se um panorama bastante integrado, pois o uso do arroz em abertura de área é sucedido ora por outra cultura, ora por pastagem. Em suma, a principal razão em se cultivar arroz é a abertura de área para a expansão de novas fronteiras agrícolas, a rotação de culturas e a recuperação de pastagens degradadas. Porém, muitos produtores acreditam que esse perfil mudará devido à escassez de áreas a serem desmatadas, ao uso de tecnologia que propicie um cultivo rentável em áreas velhas e ao aumento da prática de rotação de culturas. A indústria arrozeira pode constituir-se em outro incentivo ao cultivo de arroz pela possibilidade de melhorar o mercado e tornar o produtor mais profissional nesta atividade.

O sistema de cultivo em plantio direto não é utilizado para o arroz, somente é praticado para a soja e o milho. Alguns produtores da região centro e leste tentaram o cultivo do arroz sob esse sistema, mas relataram que o sistema radicular da cultura desenvolve-se superficialmente, tornando-se vulnerável ao acamamento. Além do mais, o controle de ervas daninhas de folha estreita é difícil pela falta de herbicidas eficientes e acessíveis.

As variedades de arroz mais cultivadas no Mato Grosso são em ordem de importância a Primavera, Cirad 141, Maravilha e Bonança, havendo ainda pequena participação de outras variedades, como Sucupira, por exemplo. Dependendo da localidade e da principal atividade econômica, se pecuária ou agricultura, pode-se ter uma mudança na representatividade da variedade mais plantada. Observa-se, na Tabela 11, a participação das variedades Primavera, Cirad 141, Maravilha, Bonança e Sucupira na safra 2001/02 em alguns municípios do Mato Grosso. Os dados foram obtidos junto aos informantes da Conab, secretários de agricultura dos municípios e/ou técnicos de agricultura da prefeitura local, não tendo sido feito um levantamento sistemático para averiguar a veracidade deles. No entanto, considera-se que essas informações são uma boa "proxy” para a análise de representatividade das variedades utilizadas. 
Tabela 11. Participação percentual de cultivares de arroz na safra 2001/02 no Mato Grosso.

\begin{tabular}{ccccccc}
\hline Municípios & Primavera & Cirad 141 & Maravilha & Bonança & Sucupira & Outras \\
\hline Nova Mutum & 90 & 8 & 0 & 0 & 2 & 0 \\
Lucas do Rio Verde & 70 & 0 & 15 & 10 & 0 & 5 \\
Tapurah & 80 & 5 & 0 & 15 & 0 & 0 \\
Cláudia & 95 & 4 & 0 & 1 & 0 & 0 \\
Sinop & 35 & 45 & 7 & 6 & 7 & 0 \\
Sorriso & 35 & 35 & 10 & 10 & 10 & 0 \\
Santa Carmem & 30 & 70 & 0 & 0 & 0 & 0 \\
Alta Floresta & 30 & 50 & 0 & 0 & 0 & 20 \\
Matupá & 40 & 35 & 25 & 0 & 0 & 0 \\
Paranaíta & 20 & 25 & 40 & 0 & 0 & 15 \\
Nova Canaã do Norte & 20 & 60 & 20 & 0 & 0 & 0 \\
Colíder & 20 & 60 & 10 & 5 & 5 & 0 \\
Peixoto de Azevedo & 20 & 65 & 15 & 0 & 0 & 0 \\
Novo Mundo & 0 & 60 & 40 & 0 & 0 & 0 \\
\hline
\end{tabular}

Fonte: dados da pesquisa.

Em relação aos aspectos qualitativos, com base nas informações dos entrevistados, constatou-se que a variedade Primavera é a preferida do mercado por possuir características de grão longo fino, por poder ser comercializada logo após a colheita (não sendo necessário tempo para atingir o ponto de maturação) e por apresentar boas qualidades culinárias, como baixo tempo de cozimento. Os problemas encontrados nesta variedade dizem respeito aos aspectos agronômicos, como susceptibilidade ao acamamento e às pragas e doenças. Muitos entrevistados citaram o problema de mistura varietal $^{3}$ como a maior dificuldade relacionada a essa variedade. Os produtores

\footnotetext{
${ }^{3}$ A chamada mistura varietal foi decorrência das segregações originadas em função da heterozigosidade potencial que libera variabilidade ao longo do tempo, especialmente quando se envolve genitores geneticamente distantes. Pode ser também conseqüência de cruzamentos naturais ocorridos em anos anteriores, quando ainda linhagem. De qualquer maneira o nível de segregação observado, ao redor de $0,2 \%$, foi muito baixo para que se pudesse descaracterizar a variedade. A segregação foi observada para a forma do grão, pois a uniformidade das plantas no campo era muito alta. A dimensão do problema foi muito maior do que na realidade ele foi, certamente em razão do impacto que a variedade provocou, em termos de produção e especialmente de qualidade de seu produto.
} 
registraram, principalmente os da região central, que solicitaram aos pesquisadores da Embrapa o retorno da variedade Primavera pura, para a melhoria da atividade na região, uma vez que ela é a preferida pela indústria de beneficiamento. Pesquisadores da Embrapa Arroz e Feijão, da área de melhoramento vegetal, afirmaram que brevemente será lançada uma nova variedade de arroz com as mesmas características da Primavera, com a vantagem de ser menos susceptível às pragas e doenças. Salienta-se que seria bastante interessante que o produtor tivesse o benefício da escolha das variedades, incluindo-se a Primavera, aumentando o leque de opções.

As vantagens da variedade Cirad 141 são sua produtividade e resistência, porém, essa variedade possui um grande problema mercadológico, pois necessita de aproximadamente 90 dias para atingir o ponto de maturação que lhe confere bons atributos culinários. A variedade Maravilha apresenta problemas de susceptibilidade às pragas e doenças, alta sensibilidade a manchas do grão, é bastante exigente em adubação, o grão é de pior qualidade, o seu beneficiamento é mais difícil e ela precisa de um tempo para maturar e ser comercializada.

É importante observar que 50\% dos produtores entrevistados não utilizam sementes certificadas porque não encontram o produto com facilidade no mercado, não depositam confiança em alguns locais de produção de sementes e crêem que a semente certificada não aumenta a produtividade. Entretanto, os outros $50 \%$ dos produtores entrevistados utilizam semente certificada por considerarem que ela resulta em um produto de melhor qualidade, por oferecer maior segurança contra as doenças e por proporcionarem maior produtividade.

Percebe-se, com essas informações, que há uma demanda não atendida, tomando-se como referência o percentual de produtores que não utilizam semente certificada por dificuldades em encontrar o produto no mercado. Há a necessidade de se fazer um trabalho de conscientização sobre as vantagens das sementes melhoradas, mostrando que elas trazem benefícios ao setor. Um fator preocupante é a falta de confiança dos produtores em algumas empresas produtoras de sementes, tornando indispensável um levantamento para que seja realizada uma nova concessão de direito para produzir esse insumo. Ferreira \& Yokoyama (1999) estimaram que apenas 49\% da 
demanda por sementes foram supridas. A substituição das sementes por grãos no momento do plantio pode acarretar conseqüências danosas para a cadeia produtiva. $\mathrm{O}$ uso de sementes melhoradas é maior em lavouras irrigadas do que em terras altas.

\subsubsection{Região norte mato-grossense}

De maneira geral, os municípios desta região têm a pecuária como a principal atividade econômica, sendo seguida pela atividade agrícola, destacando-se o arroz, o milho e a soja. Os municípios visitados foram da microrregião Colíder que é a terceira microrregião de maior produção de arroz, e Alta Floresta que pertence à microrregião de seu nome e constitui-se na oitava microrregião com maior representatividade na orizicultura.

Como a atividade principal é a pecuária, o sistema produtivo adotado consiste na abertura da área, com o cultivo do arroz perdurando um ou dois anos no máximo, pois a partir do terceiro há uma queda bastante acentuada da produtividade. Após o cultivo do arroz, a área é ocupada por pastagem que permanece no solo até sua degradação, cujo tempo é difícil de ser previsto e depende do manejo do pasto. A rotação de culturas com o arroz não alcança sequer 5\% da área dos municípios visitados. Pode-se afirmar que os principais motivos de se cultivar arroz na região são a abertura de área e sua utilização na recuperação dos pastos degradados.

Torna-se bastante difícil estimar o uso do arroz para recuperação dos pastos degradados, uma vez que este depende do manejo das pastagens e do rebanho. Contudo, estima-se um tempo médio de 11 anos para a degradação dos pastos. Instituições de pesquisa agrícola do setor orizícola no Centro-Oeste trabalham no intuito de desenvolver tecnologias para que o arroz possa se estabelecer estavelmente dentro do sistema de produção de rotação de culturas e em áreas bem definidas.

Villar et al. (2002a) apresentam um mapa identificando a produção agrícola no Mato Grosso, onde se verifica que a soja não tem grande representatividade na região norte. Foi constatado, por meio das entrevistas, que há uma tendência de substituição da 
orizicultura pela sojicultura. Em alguns casos, houve o plantio de arroz em safrinha, pelo seu mercado ser mais atraente do que o do milho, porém o risco de perda é alto devido aos períodos de estiagem. Esta experiência também foi observada na região central. A maioria dos produtores de arroz da região enquadra-se como produtores esporádicos.

O período de abrangência da análise das quatro regiões de estudo do sistema produtivo é de 1990 a 2001, pois anteriormente a 1990 algumas microrregiões não existiam, resultando em microrregiões bem maiores que as classificadas atualmente. Verifica-se, além do mais, que determinadas microrregiões não produziam determinado produto, como algodão e soja, não havendo, portanto, informações para os mesmos. No Apêndice 1 é feita a identificação das microrregiões do Mato Grosso com seus respectivos municípios. A partir de 1990, o IBGE define as microrregiões como as atuais, porém, alguns municípios ainda não tinham alcançado a emancipação.

A Figura 9 retrata o comportamento da produção de algodão, arroz, milho e soja na região norte mato-grossense e a Figura 10 mostra esse comportamento na forma de índice. 


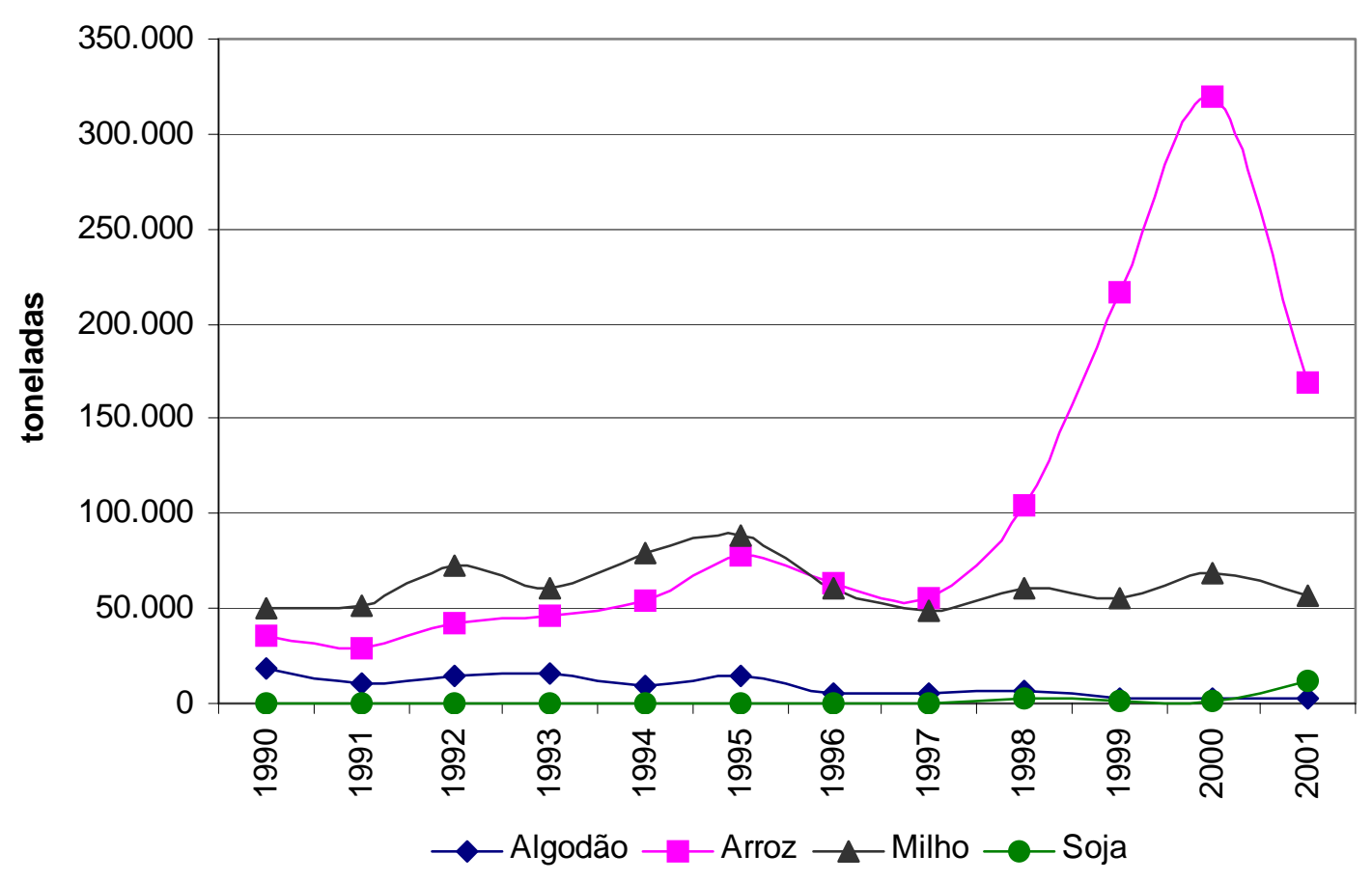

Figura 9 - Produção agrícola da região norte mato-grossense.

Fonte: IBGE (2003d)

Na Figura 9 pode-se observar um acentuado aumento da produção de arroz entre 1998 e 2000, para em seguida haver um grande decréscimo em virtude da redução na área. A produção de arroz aumentou à taxa de 20,9\% a.a., ao contrário da produção de algodão, que teve uma taxa anual negativa de crescimento de 16,5\%. A cultura do milho cresceu a uma taxa bastante reduzida $(0,0481 \%$ a.a.). A soja vem crescendo a taxas de 72,3\% a.a. na região norte do Mato Grosso, que se encontra em fase de expansão da fronteira agrícola. 


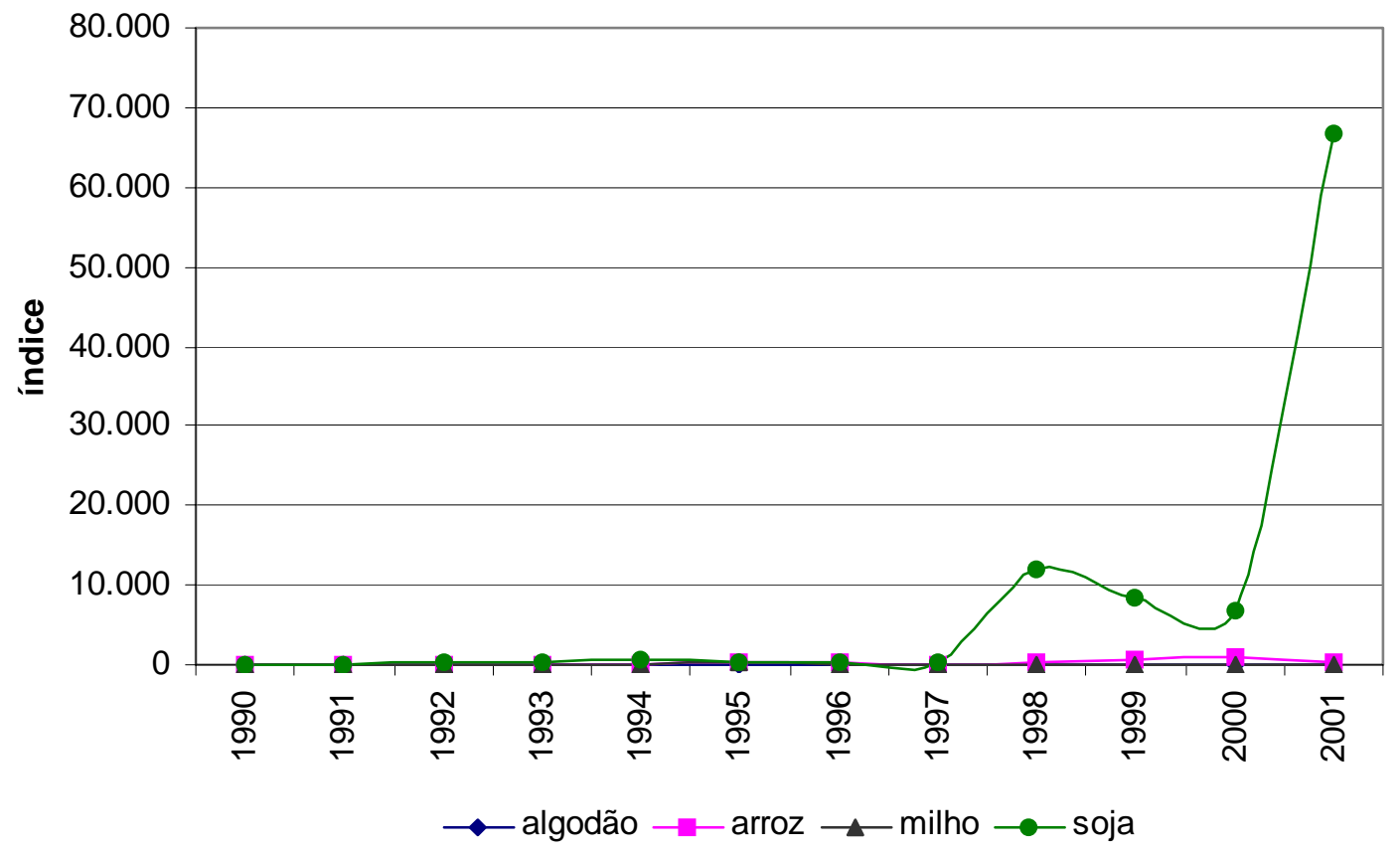

Figura 10 - Índice da produção de culturas da região norte mato-grossense.

Fonte: IBGE (2003d)

Percebe-se, na Figura 10, o altíssimo crescimento da soja na região, desde 1998, contudo, a elevação foi mais marcante nos dois últimos anos. A soja cresceu 66.733\% ao longo da década de 1990 e início da década de 2000, passando de 18 t em 1990 para 12.030 t em 2001. Nota-se que a produção de soja na região norte ainda é baixa (Figura 9). O arroz foi a segunda cultura que mais cresceu nesse período (379\%), conforme foi comentado anteriormente.

Na Figura 11 pode-se visualizar que ocorreu aumento de área apenas nos casos das culturas do arroz e da soja. Vale observar que a área cultivada com soja ainda é bem pequena, comparativamente às do arroz e do milho. A taxa anual de crescimento da área de arroz e soja foi de 11,4\% e 65,1\%, respectivamente. As culturas do algodão e do milho tiveram taxa de crescimento negativo de 20,2\% a.a. e 5,3\% a.a., respectivamente. A região norte mato-grossense é uma nova área de fronteira agrícola e se estende ao sul do Pará, pelo eixo da BR-163, sendo a proximidade dessa rodovia uma das razões para o grande aumento na produção e área cultivada com arroz. 


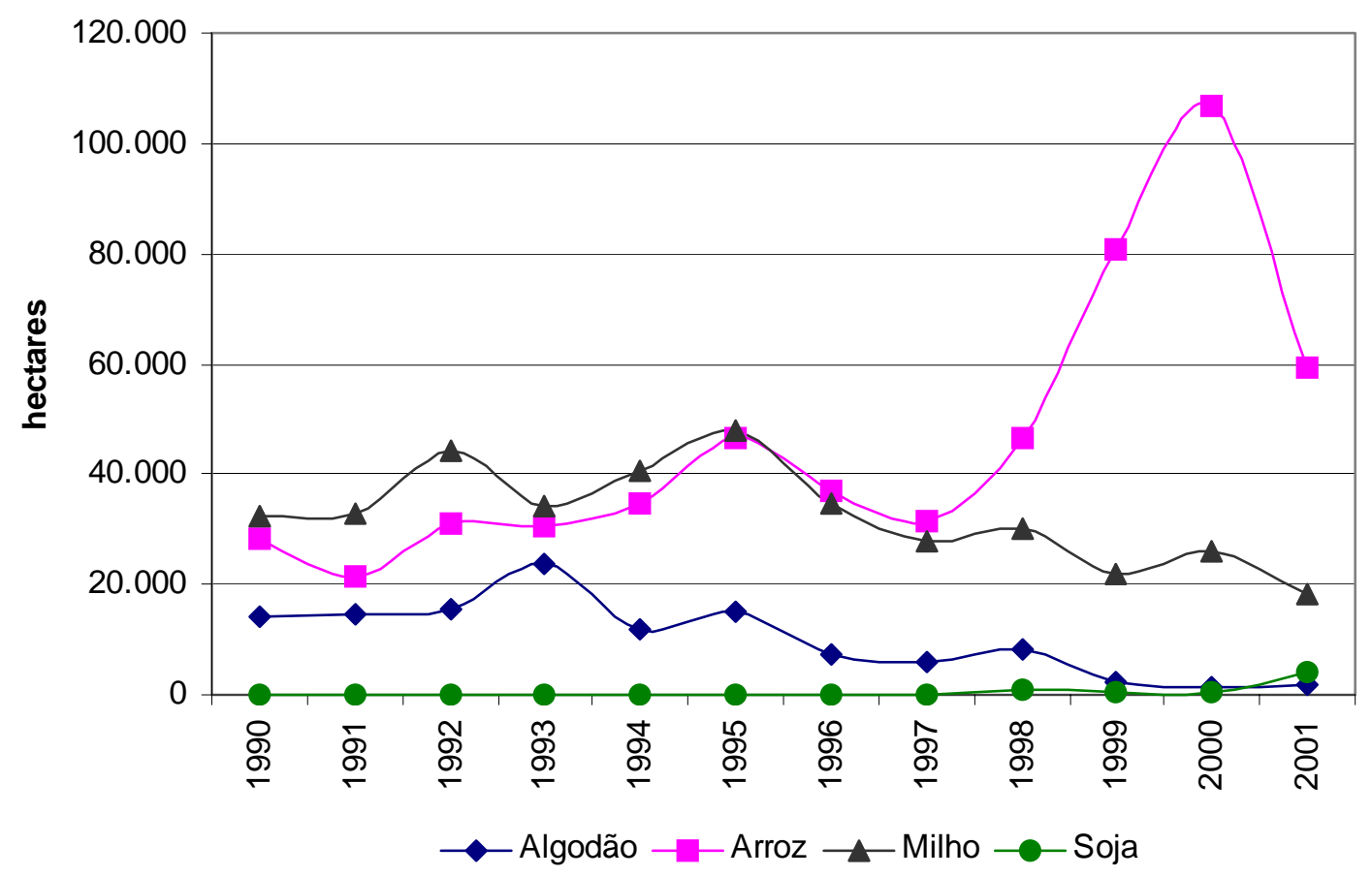

Figura 11 - Área de culturas na região norte mato-grossense. Fonte: IBGE (2003d)

A Figura 12 retrata a evolução da área das culturas na região norte na forma de índice. 


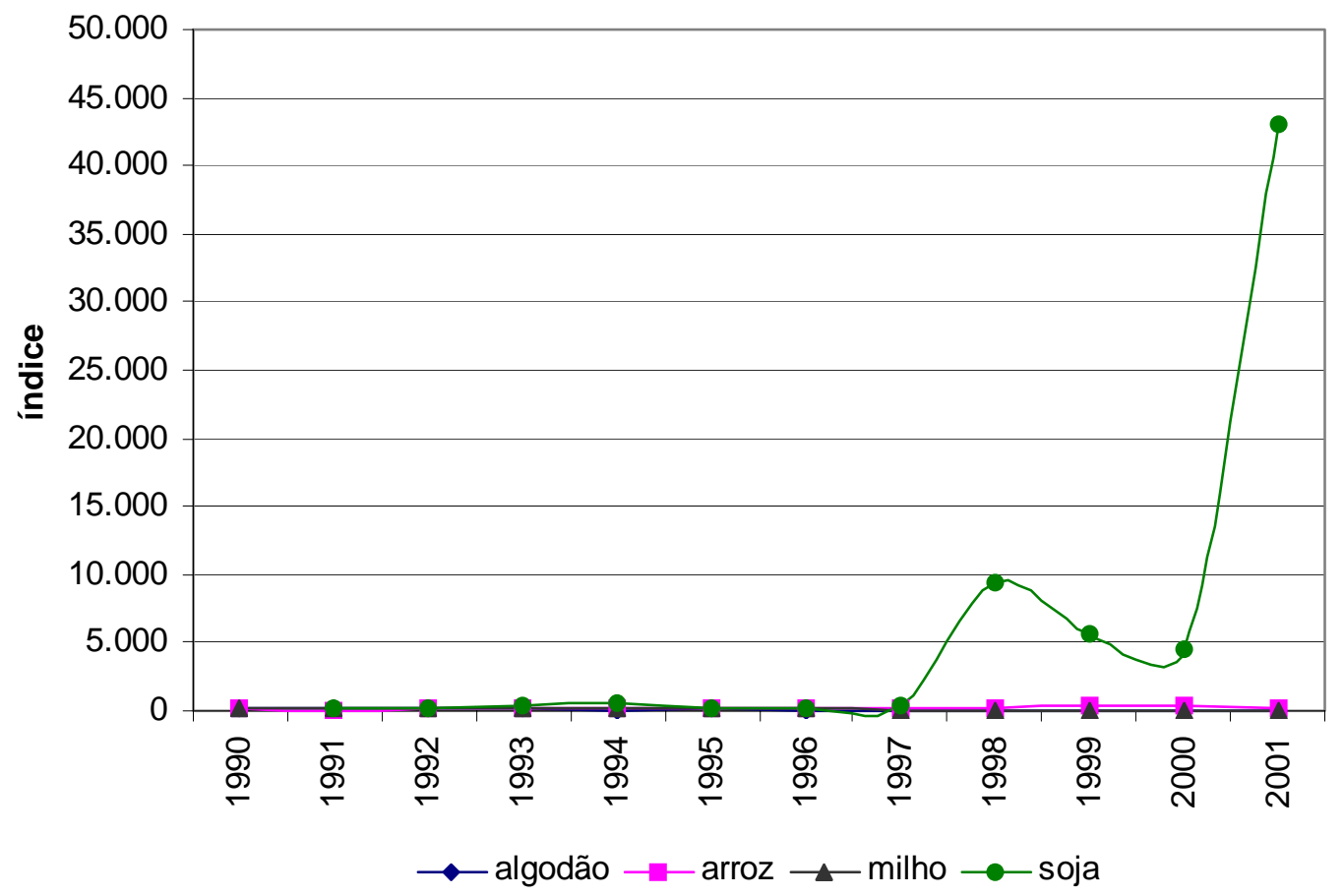

Figura 12 - Índice de área das culturas na região norte mato-grossense.

Fonte: IBGE (2003d)

Nas Figuras 10 e 12 identifica-se a semelhança do comportamento da área e da produção das culturas de interesse na região norte mato-grossense. O crescimento da soja foi muito grande, impossibilitando melhor visualização da evolução da área das outras culturas (algodão, arroz e milho). A área de cultivo de soja cresceu $42.900 \%$ na década de 1990, contudo sua área em termos absolutos ainda é pequena (Figura 11).

As principais variedades de arroz cultivadas na região norte são: Cirad 141, Primavera e Maravilha. A preferência pela variedade Cirad 141 está relacionada à sua rusticidade, resistência a pragas e a doenças e boa produtividade, adaptando-se bem ao sistema produtivo voltado à pecuária. Esta variedade, no entanto, apresenta menor aceitação na indústria devido aos problemas de maturação pós-colheita. De acordo com Villar et al. (2002b), a variedade Cirad 141 é mais cultivada nos municípios da região norte do Mato Grosso com participação de 65\% em Peixoto de Azevedo, 60\% em Colíder, Novo Mundo e Nova Canaã do Norte e 50\% em Alta Floresta. 
A variedade Maravilha também é bastante plantada; sua participação chegou a ser de 40\% em Paranaíta e Novo Mundo, 25\% em Matupá e 20\% em Nova Canaã do Norte. Os problemas dessa variedade consistem na alta susceptibilidade às pragas e doenças, alta sensibilidade a manchas do grão e exigência em adubação. Em função destes problemas, os custos de produção tornam-se maiores. A baixa qualidade do produto na culinária e as dificuldades de beneficiamento também foram indicadas como entraves ao maior uso dessa variedade.

A variedade Primavera encontra-se em $40 \%$ da área destinada à cultura do arroz em Matupá, 30\% em Alta Floresta, 20\% em Colíder, Nova Canaã do Norte, Paranaíta e Peixoto de Azevedo.

O cultivo em plantio direto na palha é realizado apenas no caso do milho e da soja, mas, por enquanto, é feito em pequenas extensões de área.

O arroz dessa região é praticamente todo comercializado para Sinop-MT, que possui bom parque agroindustrial, boa infra-estrutura de armazenagem, secagem e beneficiamento, captando a maior parte da produção da região norte e centro. Uma pequena parte da produção é comercializada para Santarém-PA.

\subsubsection{Região central mato-grossense}

Esta região engloba as duas maiores microrregiões produtoras de arroz, Alto Teles Pires e Sinop. A microrregião de Sinop está, conforme já descrito, sendo agrupada na região Centro por apresentar características de produção semelhantes a de Alto Teles Pires, apesar de geograficamente estar mais ao norte do estado.

Os municípios incluídos nesta região central são: Cláudia, Lucas do Rio Verde, Nova Mutum, Nova Ubiratã, Santa Carmem, Sinop, Sorriso, Tapurah e Vera. O arroz possivelmente deu origem ao nome do município de Sorriso.

A principal atividade econômica dessa região é a agricultura, destacando-se os cultivos da soja, milho, arroz, algodão e a pecuária; esta última sendo menos significativa. 
A prática agronômica da rotação de cultura não é aplicada de maneira bem definida, pois a soja, principal atividade econômica, é cultivada na mesma área de três a seis anos. A partir da colheita da soja, o arroz é cultivado por um ano ou no máximo dois para quebrar a incidência de pragas e doenças; depois desse intervalo a soja volta a ser plantada. De maneira geral, observa-se a inexistência de rotação ou sua completa indefinição. $\mathrm{O}$ arroz é a cultura pioneira no desbravamento de novas áreas agrícolas e seu cultivo dura dois anos no máximo, seja em abertura de área ou rotação de cultura.

O cultivo do milho é feito em áreas próprias e também ocorre em safrinha após a colheita da soja. Neste último caso, a área cultivada com milho abrange de 15\% a 30\% da área da soja. Alguns produtores experimentaram o plantio do arroz em safrinha ao invés do milho, mas o risco de perda em decorrência de veranicos é maior do que no caso do milho. O cultivo do algodão é realizado em áreas próprias e é a cultura menos integrada à orizicultura no quesito de rotação, estando fortemente relacionada quanto à ocupação de área.

Visualiza-se na, Figura 13, a evolução da produção das quatro culturas em estudo na região central do Mato Grosso. 


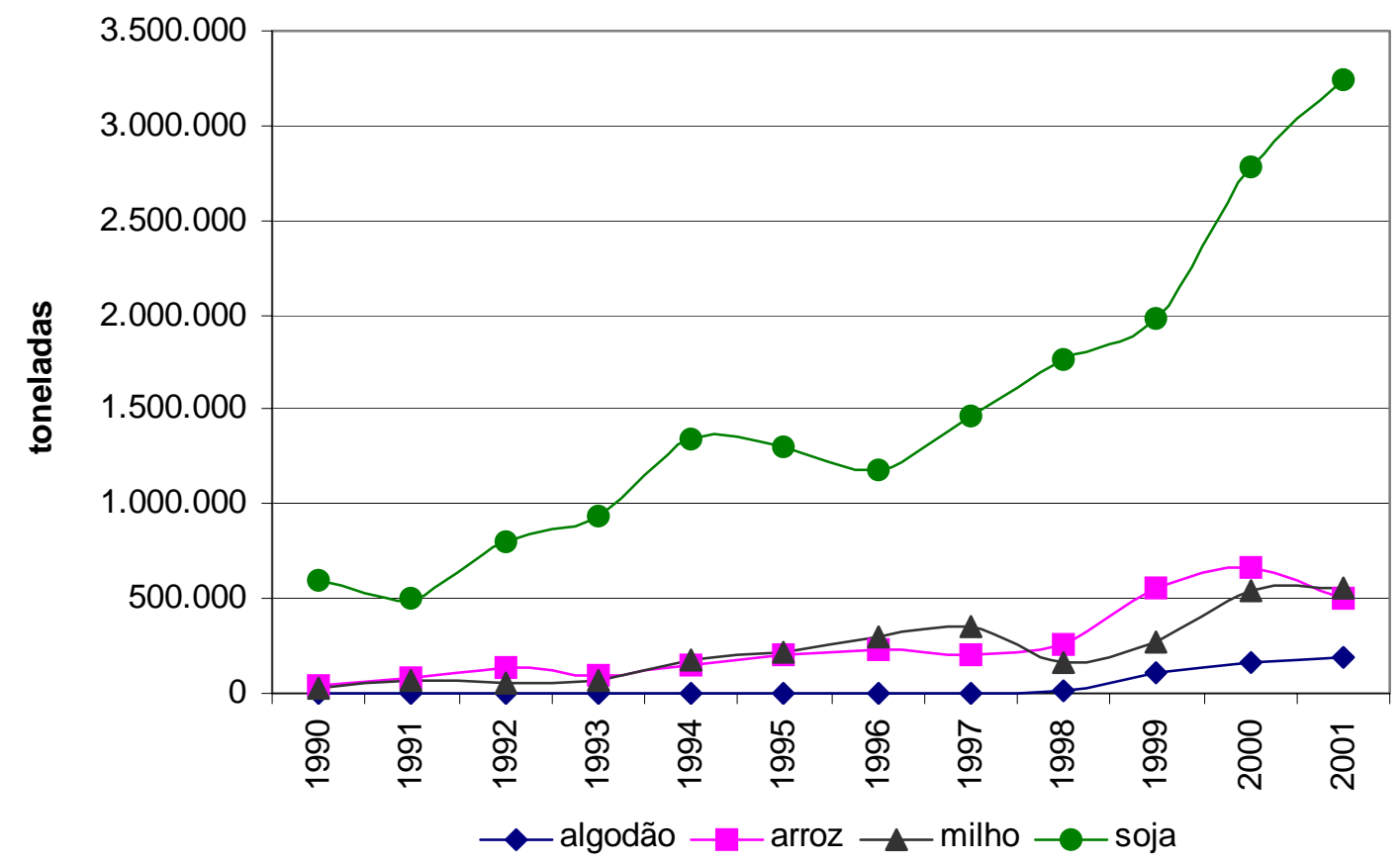

Figura 13 - Evolução da produção de algodão, arroz, milho e soja na região central do Mato Grosso.

Fonte: IBGE (2003d)

Percebe-se, na Figura 13, o grande crescimento da produção de soja ao longo da década de 90 até 2001, mas esta é a que menos cresce anualmente. A taxa anual de crescimento da produção de soja foi de $16,4 \%$. Verificou-se crescimento da produção do algodão, do arroz e do milho no mesmo período. O arroz e o milho apresentaram comportamentos similares, com taxas de crescimento de $25,1 \%$ a.a. e $27,6 \%$ a.a., respectivamente. Apesar da produção de algodão ainda ser pequena, esta cresceu à taxa de 55,4\% a.a.. A Figura 14 demonstra a evolução da produção das culturas do algodão, arroz, milho e da soja na forma de índice. 


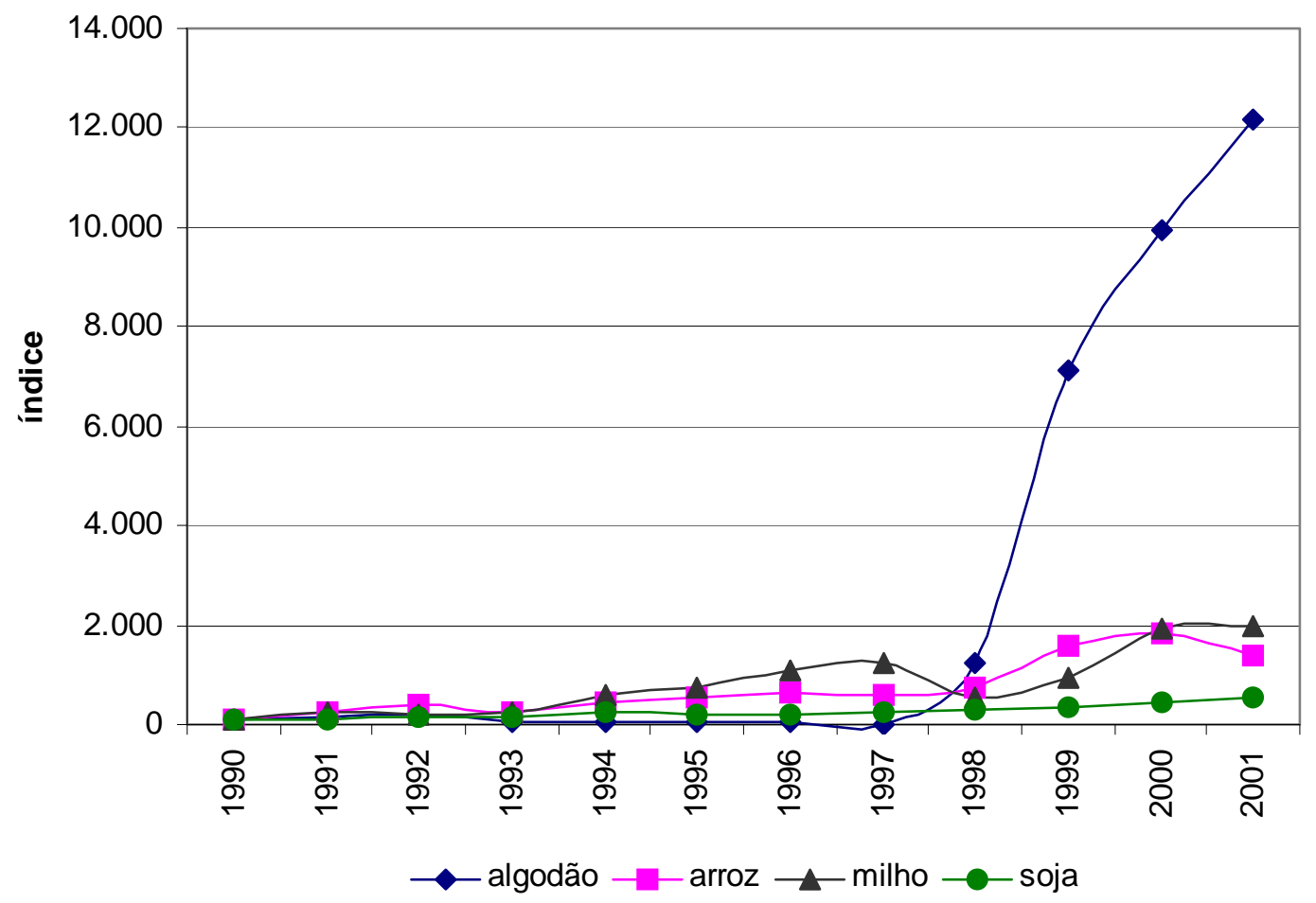

Figura 14 - Índice de produção das culturas na região central mato-grossense.

Fonte: IBGE (2003d)

Percebe-se, pela Figura 14, o grande crescimento da produção do algodão na região central do Mato Grosso, apesar da produção dessa cultura ainda ser a menor dentre as quatro analisadas (Figura 13).

A Figura 15 demonstra a evolução da área plantada das quatro culturas de 1990 a 2001 na região central mato-grossense. 


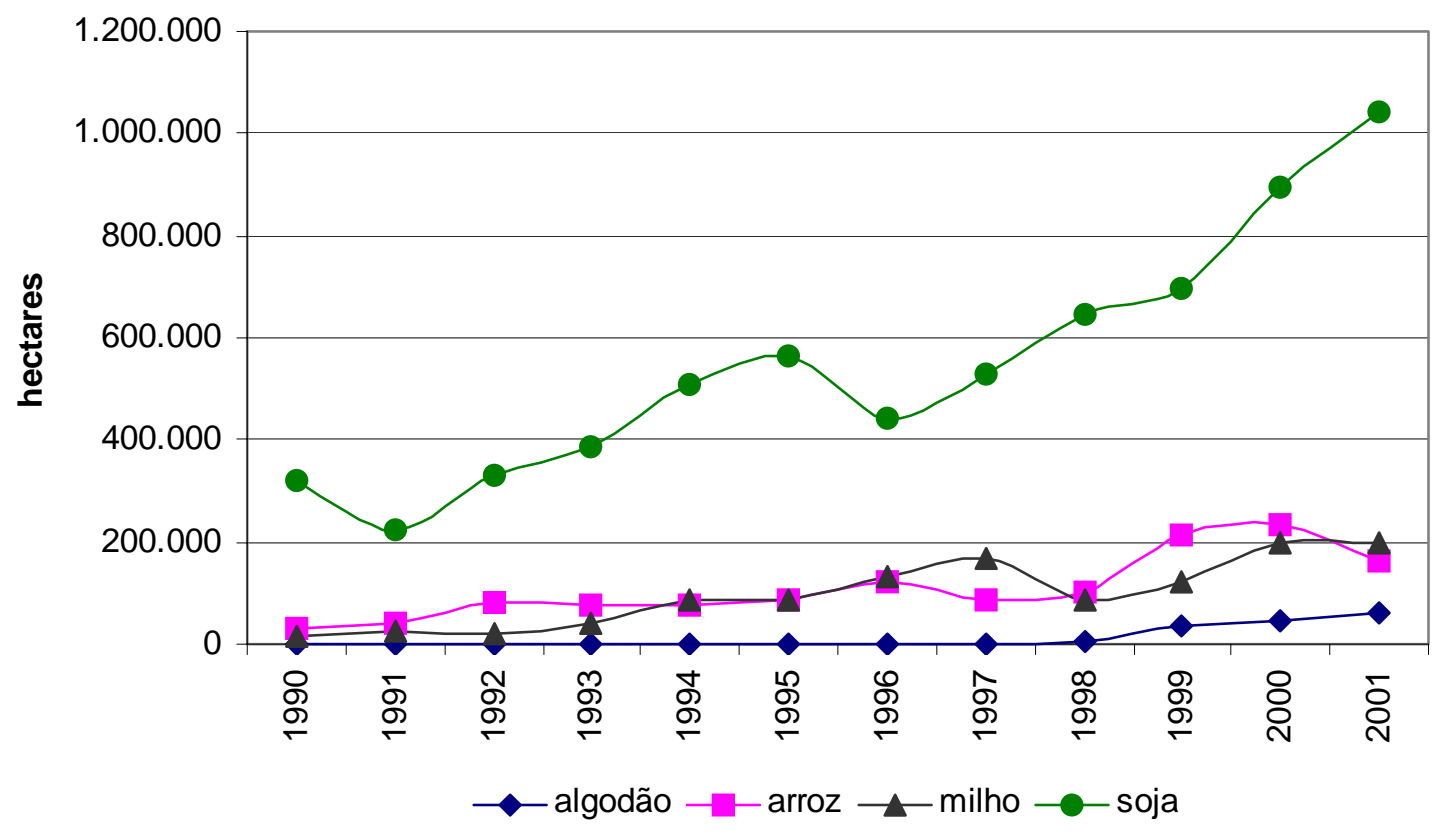

Figura 15 - Evolução da área de algodão, arroz, milho e soja na região central do Mato Grosso.

Fonte: IBGE (2003d)

O comportamento da área plantada (Figura 15) é semelhante ao comportamento da produção (Figura 13); as quatro culturas tiveram aumento de área. A área plantada com algodão aumentou 39,8\% a.a. no período considerado. O arroz e o milho cresceram a taxas de 16,3\% a.a. e 26,4\% a.a., respectivamente, e a área cultivada com soja cresceu 12,2\% ao ano. Visualiza-se na Figura 16 o comportamento da área plantada na forma de índice. 


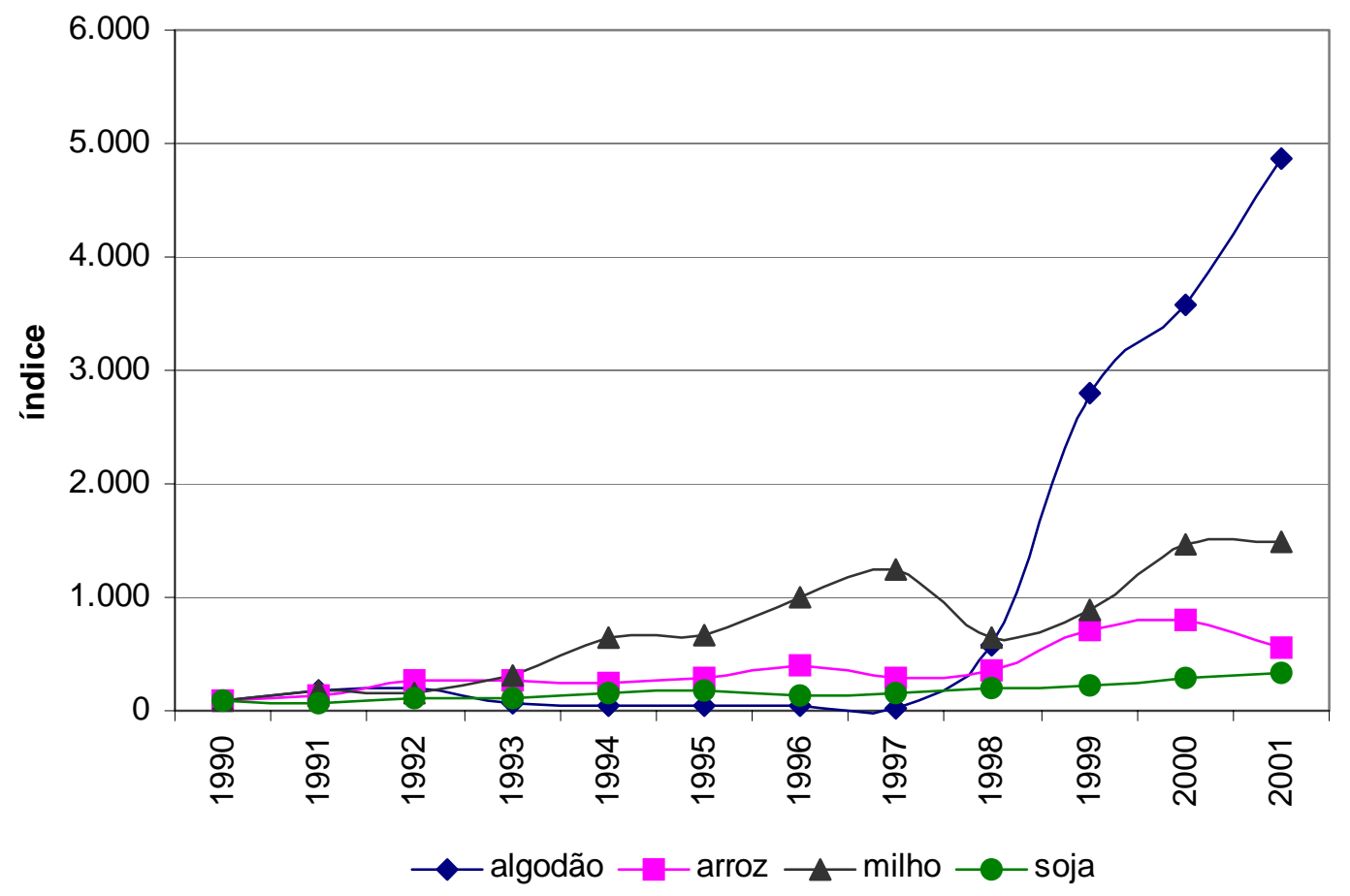

Figura 16 - Índice de área das culturas na região central mato-grossense.

Fonte: IBGE (2003d)

Destaca-se, na Figura 16, o grande crescimento da área cultivada com soja no período, contudo esta é a cultura, dentre as consideradas no estudo, que ocupa menos área na região. A área com soja cresceu $4.763 \%$ no período e a cultura do milho foi a segunda que mais cresceu no período (1.381\%).

Salienta-se novamente a dificuldade de se estimar os dados de produção e área das atuais microrregiões no período de 1980 a 1989, visto que algumas delas eram bem maiores, gerando, em alguns casos, uma superestimativa considerando a microrregião atual.

O cultivo no sistema de plantio direto é realizado apenas para a soja e o milho, mas seu uso ainda não é integral; estima-se que cerca de $75 \%$ da soja é plantada sob o sistema de plantio direto. As dificuldades do cultivo do arroz em plantio direto dizem respeito ao combate das ervas daninhas, pois conforme comentado anteriormente, os herbicidas de pós-emergência para o controle de ervas de folha estreita não tem sido 
eficientes. A planta também apresenta problemas no desenvolvimento do sistema radicular. Ainda não há tecnologia disponível para contornar essas dificuldades.

Os produtores de arroz da região central do Mato Grosso podem ser caracterizados como esporádicos. Os principais motivos que levam o produtor a cultivar arroz em ordem de importância são: abertura de área (é uma planta pouco exigente ao preparo do solo, além da plataforma da colheitadora ser alta, facilitando a colheita em terrenos irregulares), recuperação dos pastos e rotação de cultura, para reduzir a incidência de pragas e doenças. Percebe-se com isto que o arroz ainda continua carregando o estigma de estar relacionado ao processo de desbravamento de novas fronteiras agrícolas.

Não há consenso entre os entrevistados quanto à duração do uso do arroz em abertura de área, pois alguns produtores acreditam que ainda existe muita área a ser aberta e que este ainda será o papel do arroz de terras altas, tendo um deles afirmado que o processo de abertura de área com arroz deverá ser mais intenso no futuro. Por outro lado, a maioria dos agentes entrevistados acredita que o maior motivo de se plantar arroz no Centro-Oeste (abertura de área) não será mais este, pois o processo de expansão de área não deverá ser intenso, devendo-se creditar o aumento da produção ao crescimento da produtividade. Em virtude disso, alguns produtores buscam maior profissionalização no cultivo do arroz, melhorando o manejo e os tratos culturais, fazendo melhor planejamento da produção, colhendo na época correta e com a umidade ideal.

O produtor toma a decisão sobre o tamanho da área a ser cultivada com arroz com base na área a ser aberta, na necessidade de rotação de cultura, na necessidade de recuperação dos pastos, com base nos preços da safra anterior, na disponibilidade de semente, nas expectativas de preços no momento da colheita, sendo este um reflexo do comportamento dos preços do ano agrícola anterior e, por último, nos preços dos insumos utilizados na sua produção e na de soja. Um produtor não concorda que o preço dos insumos do arroz são mais altos que os da soja e, em sua opinião, isso seria um dos últimos fatores a serem observados para a definição do tamanho da área a ser cultivada, pois o fator primordial é o retorno financeiro que a atividade pode proporcionar e as necessidades técnicas de cultivo. 
A variedade mais cultivada na região centro mato-grossense é a Primavera, seguida da Cirad 141. Um fato observado foi que à medida que se caminha em direção ao norte do estado, muda progressivamente o percentual de uso das variedades. A Primavera vai perdendo espaço para a Cirad 141, que é mais rústica e resistente, sendo preferida pelos produtores daquela região, cuja atividade econômica predominante é a pecuária.

A participação das variedades na composição da área vem passando por mudanças ao longo do período, principalmente na década de 1990, quando foram lançadas novas variedades que reduziram a distância qualitativa e quantitativa entre o arroz irrigado e o de terras altas.

Na Tabela 12 identifica-se a participação das variedades de arroz utilizadas nas três últimas safras agrícolas no município de Sorriso. Dada a especificidade das informações, não é possível agrupar os municípios da região em uma única tabela. Salienta-se a dificuldade na obtenção das respostas de boa parte dos entrevistados devido à falta de informações sobre o assunto.

Tabela 12. Percentual das variedades cultivadas de arroz no município de Sorriso, nas safras 1999/00, 2000/01 e 2001/02.

\begin{tabular}{cccc}
\hline \multirow{2}{*}{ Variedades } & \multicolumn{3}{c}{ Participação \% na área cultivada } \\
\cline { 2 - 4 } & $1999 / 2000$ & $2000 / 2001$ & 35 \\
\hline Primavera & 30 & 35 & 35 \\
Cirad 141 & 60 & 42 & 10 \\
Sucupira & - & 5 & 10 \\
Maravilha & 10 & 15 & 10 \\
Bonança & - & 3 &
\end{tabular}

Fonte: dados da pesquisa.

Sorriso é o município onde se utiliza o maior número de variedades. Percebe-se a redução no cultivo da Cirad 141 e a estabilidade relativa do uso da 
Primavera e Maravilha; as variedades Sucupira e Bonança aumentaram sua participação na área plantada. Os principais problemas levantados foram que a cultivar Sucupira é bastante exigente em adubação e que a Primavera e Maravilha são susceptíveis às pragas e doenças. A Bonança tem seu grão classificado como longo, não satisfazendo parte do mercado consumidor, além de problema de maturação pós-colheita. A cultivar Cirad 141 vem perdendo espaço por causa da necessidade de tempo para atingir o ponto de maturação pós-colheita (90 dias).

A Tabela 13 demonstra a liderança da cultivar Cirad 141 em Sinop, mas esta vem perdendo espaço pelo mesmo motivo observado em Sorriso.

Tabela 13. Percentual das variedades cultivadas de arroz no município de Sinop, nas safras 1999/00, 2000/01 e 2001/02.

\begin{tabular}{cccc}
\hline \multirow{2}{*}{ Variedades } & \multicolumn{3}{c}{ Participação \% na área cultivada } \\
\cline { 2 - 4 } & $1999 / 2000$ & $2000 / 2001$ & $2001 / 2002$ \\
\hline Primavera & 10 & 30 & 35 \\
Cirad 141 & 75 & 45 & 45 \\
Sucupira & - & 25 & 7 \\
Maravilha & - & - & 7 \\
Bonança & - & - & - \\
Tolimã & 15 & - & \\
\hline
\end{tabular}

Fonte: dados da pesquisa.

Os relatos dos entrevistados quanto às variedades são os mesmos que foram descritos anteriormente. A diminuição do plantio da Sucupira deve-se ao seu grau de exigência tecnológica. A variedade Tolimã, que não é mais cultivada, citada como a menos indicada pelos produtores locais, pois é susceptível às pragas e doenças e perfilha muito.

Vários são os problemas que acometem a orizicultura no Mato Grosso, podendo-se citar as pragas e doenças e o atraso na época da colheita, pois quando esse 
período coincide com o da soja, o arroz acaba sendo preterido. A grande heterogeneidade da produção em aspectos quantitativos e qualitativos constitui-se em um fator a ser superado e isto é decorrente do variado nível tecnológico empregado na cultura.

Contudo, os principais problemas citados residem na gestão empresarial deficiente por parte de muitos produtores. Alguns agentes comentaram que a Política de Garantia de Preços Mínimos (PGPM) do arroz é desestimulante, estando os produtores sujeitos às leis de mercado. Outro problema citado é a falta de bom conhecimento técnico para a cultura do arroz por parte de órgãos e empresas de assistência técnica.

O arroz produzido na região centro mato-grossense é comercializado, em sua maior parte, em Sinop pelos motivos já descritos anteriormente (possui bom parque agroindustrial); parte do arroz é destinada a Cuiabá e a atacadistas de outros estados (Goiás, Minas Gerais e estados do Nordeste). Verificou-se a venda do arroz em casca do Mato Grosso para atacadistas de São Paulo (Santa Cruz do Rio Pardo). Não foi possível quantificar o volume de arroz negociado aos diversos destinos pela ausência das informações ou por estas serem consideradas estratégicas para a empresa agrícola.

A comercialização do arroz é bastante diferente da soja, que tem os canais de comercialização mais desenvolvidos. A soja pode ser negociada em bolsas de mercadorias e futuros, possui mercado de CPRs ${ }^{4}$ mais consolidado, pode ser vendida de forma antecipada visando o financiamento da safra agrícola ou pode ser trocada por insumos.

Um grande problema encontrado na comercialização do arroz é a grande inadimplência; em decorrência disto, as vendas são efetuadas à vista e quando realizadas a prazo (10 a 30 dias), são feitas para atacadistas que têm credibilidade no mercado.

\footnotetext{
${ }^{4}$ Cédula do Produto Rural - CPR.
} 
Nos municípios de Nova Mutum e Lucas do Rio Verde há produtores que comercializam arroz de uma maneira nada convencional; esse sistema é chamado de arroz "verde" e consiste na venda do arroz ainda na planta antes de ser colhido. O produtor repassa para o comprador a responsabilidade da colheita, secagem e armazenamento. As vantagens dessa negociação para o comprador ainda são obscuras, devido aos riscos relativos à qualidade inerentes dessa compra. Pode existir vantagem em termos de custos, pois o preço negociado do "arroz verde” normalmente é menor que o do já colhido. Esse preço pode compensar o acréscimo nos custos de pós-colheita, principalmente se o comprador tiver secador e estrutura de armazenamento.

\subsubsection{Região leste mato-grossense}

Esta região engloba as microrregiões de Primavera do Leste, Paranatinga e Canarana. As principais atividades econômicas exploradas são as mesmas da região central.

As microrregiões de Canarana e Paranatinga são, respectivamente, a quarta e quinta maiores produtoras de arroz do Mato Grosso. Primavera do Leste desponta como a décima primeira microrregião em termos de produção. Infelizmente, devido a restrições orçamentárias, não foi possível detalhar o estudo das microrregiões de Canarana e Paranatinga, sendo visitado apenas o município de Paranatinga, cuja microrregião tem o mesmo nome. Foram realizadas algumas entrevistas com produtores e com o secretário de agricultura de Primavera do Leste.

As informações referentes ao município de Água Boa, da microrregião de Canarana, foram obtidas com os pesquisadores da Embrapa Arroz e Feijão e com um pesquisador do "Centre de Coopération pour le Développement” (Cirad - França).

A região leste apresenta um padrão tecnológico superior ao da região central, pois alguns produtores fazem uso de irrigação e melhor controle da adubação. Alguns produtores também cultivam em plantio direto na palha, porém os mesmos encontram alguns entraves que a pesquisa agrícola ainda não solucionou. O problema mais relatado 
foi o exíguo desenvolvimento do sistema radicular. Encontraram-se casos em que o arroz produzido sob o sistema de irrigação de pivô central gerou bons resultados. A tecnologia de produção de arroz sob pivô central ainda não está bem difundida e adaptada, e muitos produtores não têm alcançado uma boa produção nesse sistema. Os problemas associados ao pivô central citados foram: baixa produção, alto índice de "chochamento" (relação volume peso) e maturação desuniforme dos grãos. Os problemas são mais graves quando as duas tecnologias (plantio direto na palha e irrigação) são usadas simultaneamente.

De maneira geral, o sistema de produção da região leste assemelha-se com o da região central. As principais semelhanças são: os motivos que levam o produtor a cultivar arroz, os fatores que influem no tamanho da área a ser cultivada, o sistema de rotação de cultura, as variedades mais cultivadas e os problemas que afetam a cadeia produtiva.

Apesar da semelhança dos sistemas produtivos, vale discutir alguns detalhes. Alguns produtores afirmam que a variedade Primavera está misturada com as variedades Caiapó e Carajás, o que resulta em mancha dos grãos no momento da secagem, devido à desuniformidade na maturação dos mesmos. Tanto produtores como agroindústria são favoráveis a que a Embrapa insista na variedade Primavera ou lance a Primavera II.

Os problemas da variedade Maravilha e Bonança são os mesmos descritos anteriormente. A variedade Tolimã causou muitos prejuízos aos produtores por apresentar baixa produtividade e baixa qualidade do grão. A variedade IAC - 202 é bem produtiva, mas não tem boa aceitação devido a problemas associados à cocção. A Sucupira é bastante exigente em tecnologia e tem problema de enchimento dos grãos.

O arroz da região leste é vendido, em boa parte, para Cuiabá, Goiânia e para as cidades do interior do Nordeste. O arroz vendido para o Nordeste é de qualidade inferior.

A Figura 17 apresenta a evolução da produção das quatro culturas de interesse na região leste. Visualiza-se, nessa Figura, a importância da soja na região leste e o repentino crescimento da cultura do algodão, ultrapassando em produção o arroz e o milho. A soja cresceu à taxa anual de 7,8\%. O algodão cresceu a uma taxa anual de 
205,8\%. O arroz cresceu a uma taxa anual de 5\%, enquanto que o milho cresceu a taxa de 10,9\% a.a.. A Figura 18 demonstra a evolução da produção na forma de índice para melhor visualizar o crescimento das culturas.

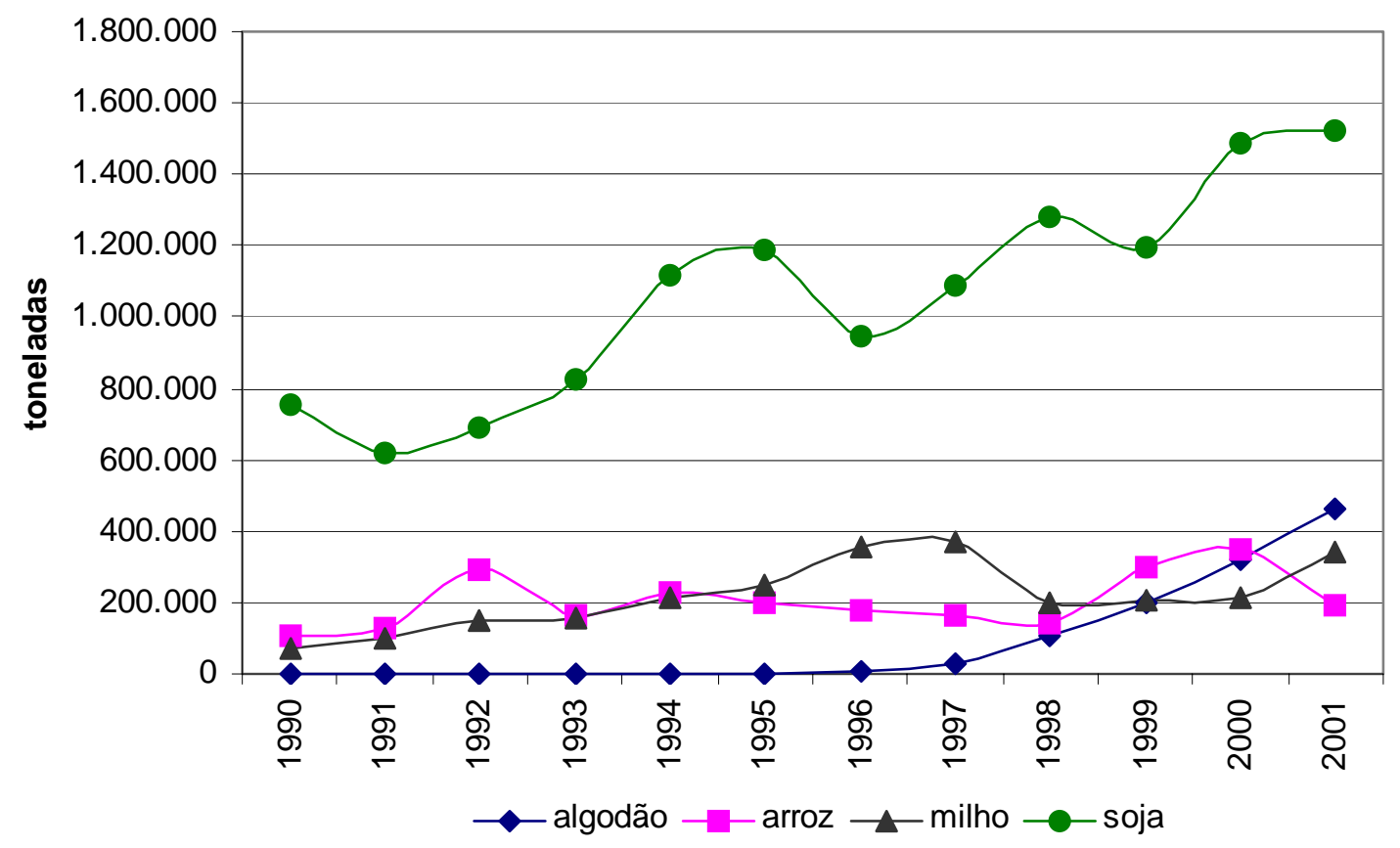

Figura 17 - Evolução da produção de algodão, arroz, milho e soja na região leste do Mato Grosso.

Fonte: IBGE (2003d) 


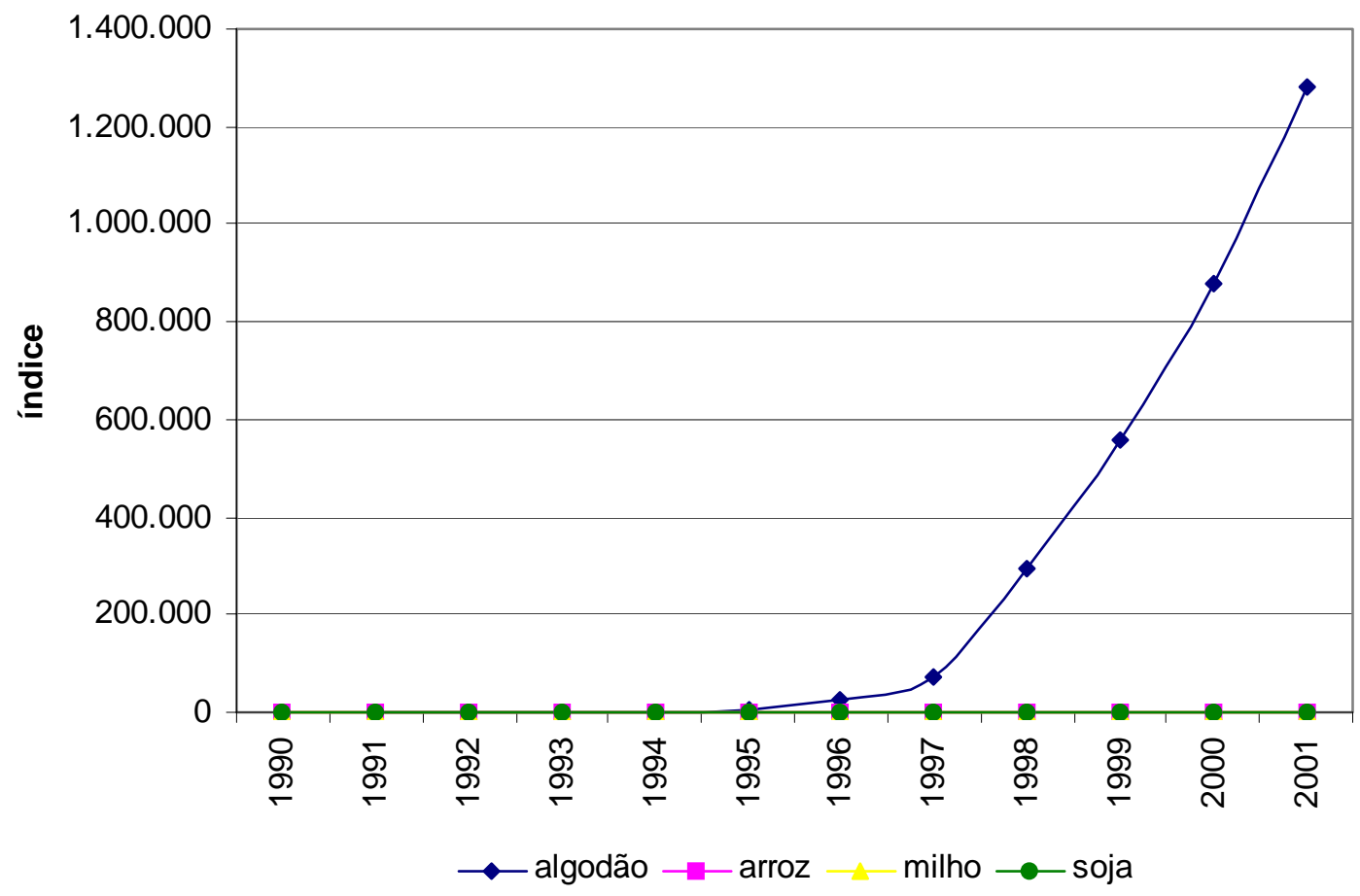

Figura 18 - Índice de produção das culturas na região leste mato-grossense.

Fonte: IBGE (2003d)

Na realidade, a Figura 18 demonstra apenas o espetacular crescimento da produção de algodão no período, neutralizando graficamente o crescimento das demais culturas. O algodão cresceu 1.282.008\%, passando de 36 t em 1990 para 461.559 t em 2001.

Na Figura 19, identifica-se o aumento na área plantada de soja, algodão e milho. A área de arroz decresceu à taxa anual de 1,1\%. A área plantada com soja cresceu 4,2\% a.a., enquanto que a taxa anual de crescimento da área de milho foi de 8,7\%. A área do algodão teve um crescimento de $162,2 \%$ a.a.. 


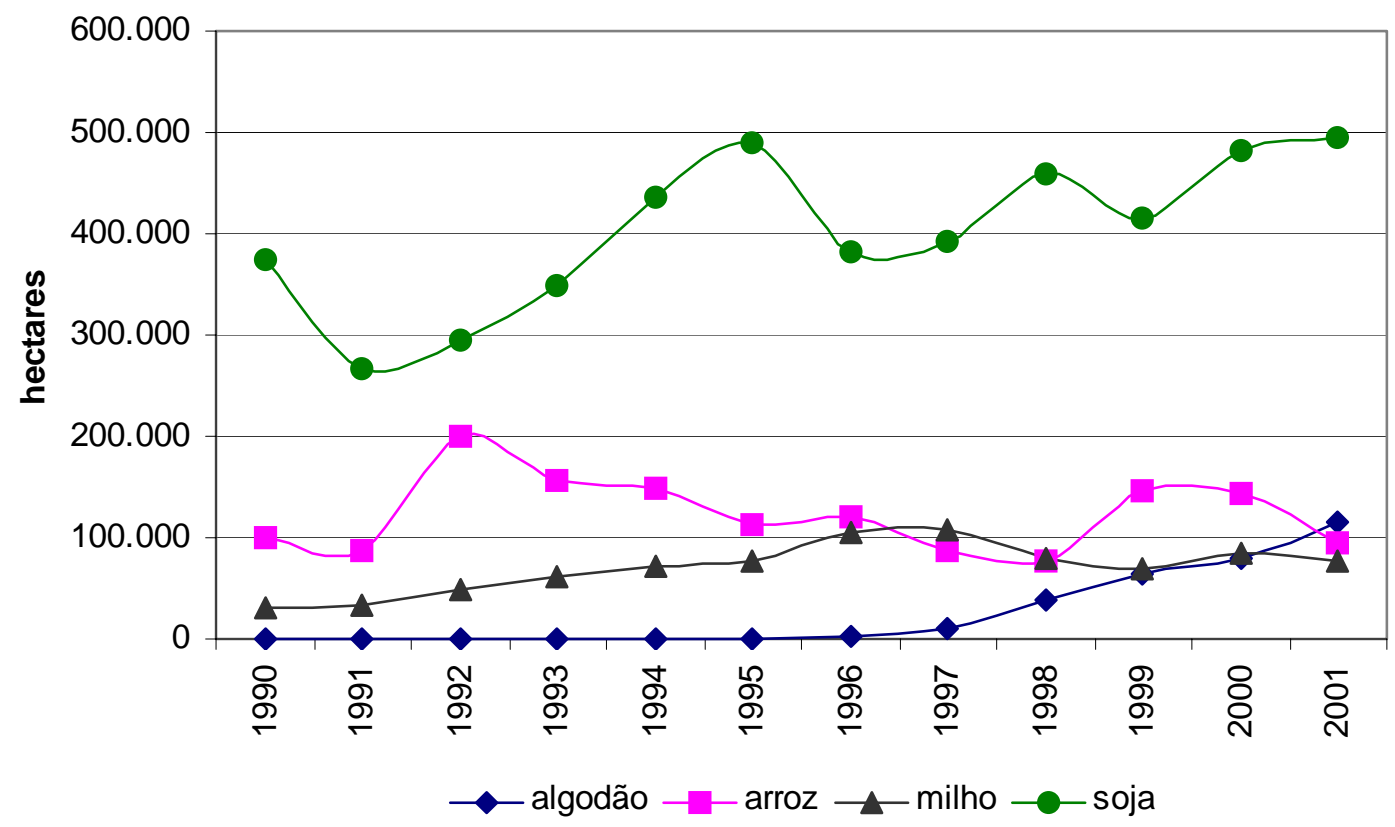

Figura 19 - Evolução da área de algodão, arroz, milho e soja na região leste do Mato Grosso.

Fonte: IBGE (2003d)

A Figura 20 trata da evolução da área das culturas de interesse no estudo na região leste na forma de índice. Verifica-se, outra vez, o grande crescimento da área da cultura do algodão, mascarando graficamente o comportamento das outras culturas. Eram cultivados 35 ha de algodão em 1990, e em 2001 a área plantada com algodão era de 115.264 ha; aumento de 329.226\% no período. 


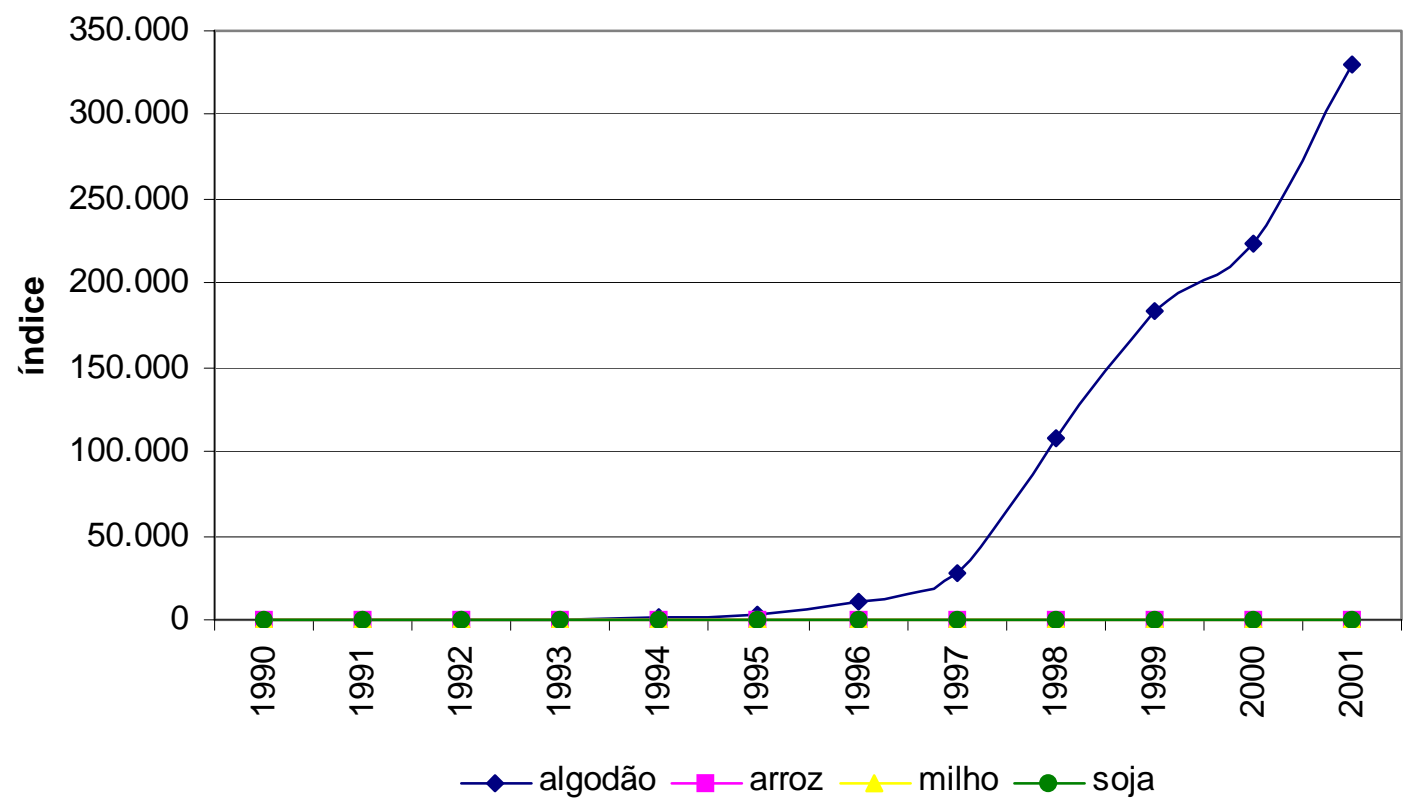

Figura 20 - Índice de área das culturas na região leste mato-grossense.

Fonte: IBGE (2003d)

\subsubsection{Região oeste mato-grossense}

Esta região é representada pela microrregião de Parecis, cujos municípios visitados foram Comodoro e Campos de Júlio. Esta microrregião é a sexta maior produtora de arroz no Mato Grosso. Devido a restrições orçamentárias, não se visitou o município de Diamantino, o maior produtor da microrregião.

$\mathrm{O}$ oeste do Mato Grosso também se assemelha à região centro em quase todos os aspectos tratados nesta análise.

As principais diferenças dizem respeito aos aspectos comerciais. Verificouse, principalmente em Comodoro, relação comercial com Rondônia, baseada no fato de que uma parte do arroz produzido em Comodoro é transportado para Rondônia para ser beneficiado, havendo também um grande fluxo de arroz para Campos de Júlio e Sapezal, com finalidades de armazenagem, beneficiamento e comerciais. Um produtor de 
Comodoro está investindo na instalação de armazém e secador no intuito de melhorar a infra-estrutura pós-colheita e possibilitar melhores opções para a comercialização.

De forma geral, os produtores desta região comentam que o clima é muito bom para a produção de arroz, com as estações bem definidas. As condições climáticas do Sul (especialmente, oeste do Paraná) não são muito favoráveis, pois o risco de perda é muito alto em virtude de estiagens, chuvas no período de florescimento e geadas. As reservas indígenas da região são benéficas ao setor por causa do equilíbrio ambiental; isso acaba fazendo diferença em relação a Sapezal e Sinop, pois os custos são mais baixos.

Um fato observado é que alguns agricultores produzem a própria semente ou fazem do grão uma semente, visando reduzir os custos de produção do próximo cultivo. Isto pode acarretar prejuízos para o setor pela diminuição da produção e da qualidade do grão.

Em geral, a comercialização do arroz da região oeste é realizada para Rondônia para beneficiamento e daí é vendida para o Acre, Manaus e outras localidades do Norte brasileiro.

Destaca-se, na Figura 21, o crescimento da produção de soja na região (15,2\% a.a.). A cultura do algodão cresceu a uma taxa anual de $41,2 \%$, superando a produção de arroz e milho. A cultura do milho cresceu a taxa de 7,2\% a.a. e 0 arroz cresceu anualmente à taxa de 6,6\%. A Figura 22 demonstra o comportamento da produção das culturas na região oeste na forma de índice. 


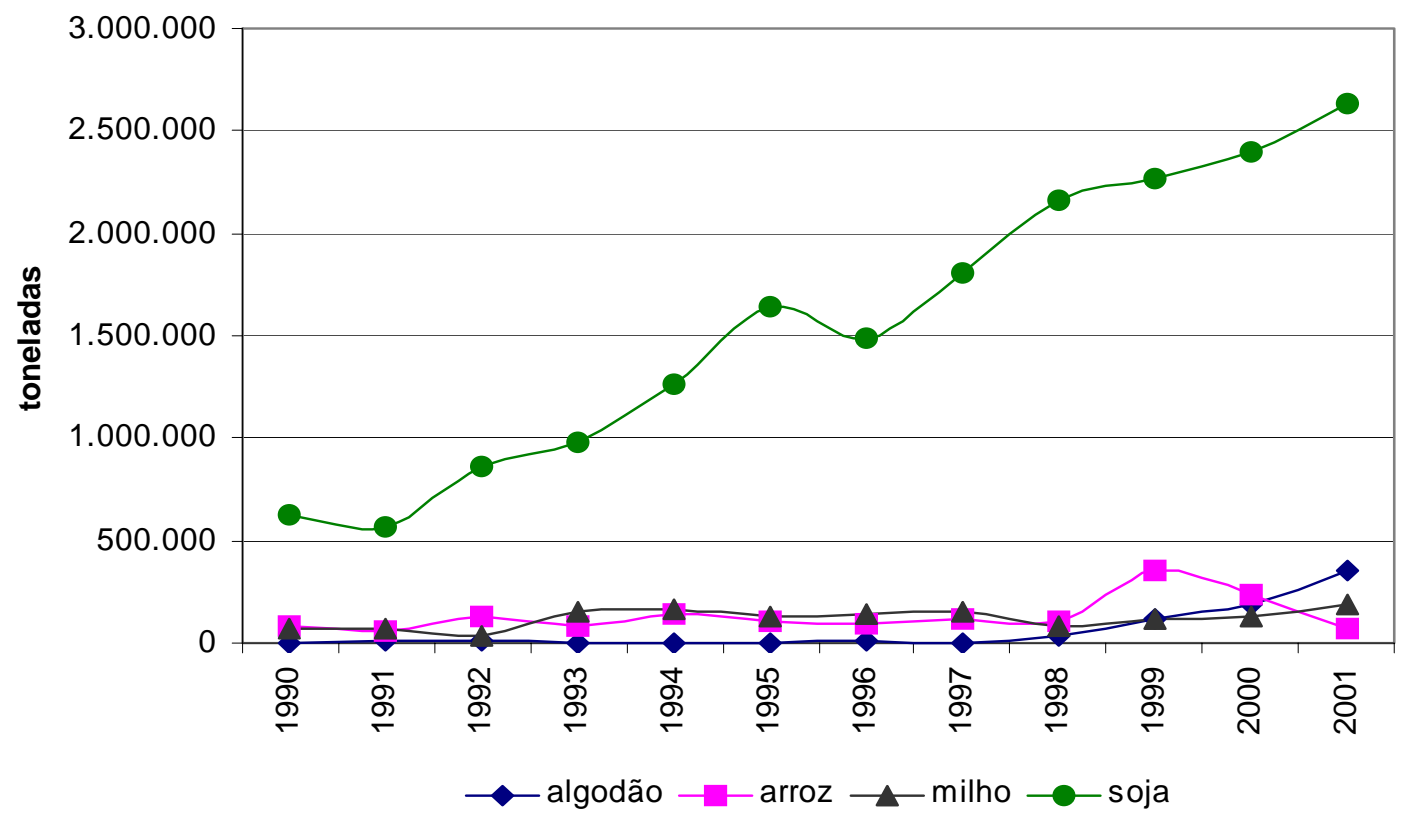

Figura 21 - Comportamento da produção de culturas selecionadas na região oeste, de 1990 a 2001.

Fonte: IBGE (2003d)

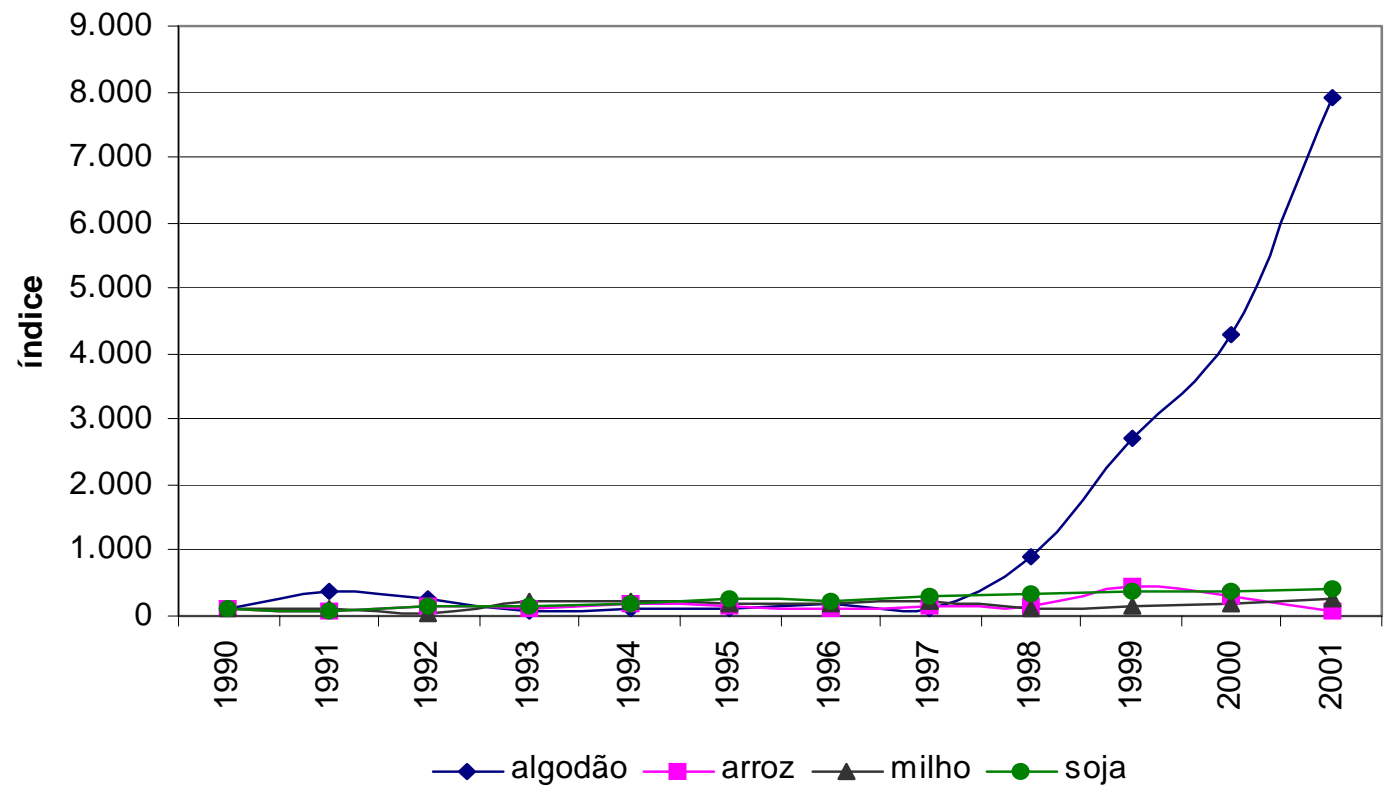

Figura 22 - Índice de produção das culturas na região oeste mato-grossense.

Fonte: IBGE (2003d) 
Assim como na região leste, o algodão também cresceu bastante no período, passando de 4.516 t em 1990 para 356.903 t em 2001. O algodão só perde em produção para a soja, como pode ser visto na Figura 21. Aliás, percebe-se que o algodão cresceu consideravelmente nas regiões central, leste e oeste a partir de 1997.

Visualiza-se, na Figura 23, a grande participação da soja na área agricultável da região oeste. A área de soja cresceu à taxa anual de 11,9\%. A área de algodão cresceu à elevada taxa de 30,3\% a.a., sendo a segunda cultura mais plantada na região. $\mathrm{O}$ arroz era a segunda cultura mais plantada até 2001, perdendo apenas para a soja, porém nesse ano foi superado pelo algodão e milho. A área cultivada com arroz teve um pequeno aumento de $0,6 \%$ a.a. e a área do milho cresceu 10,9\% a.a..

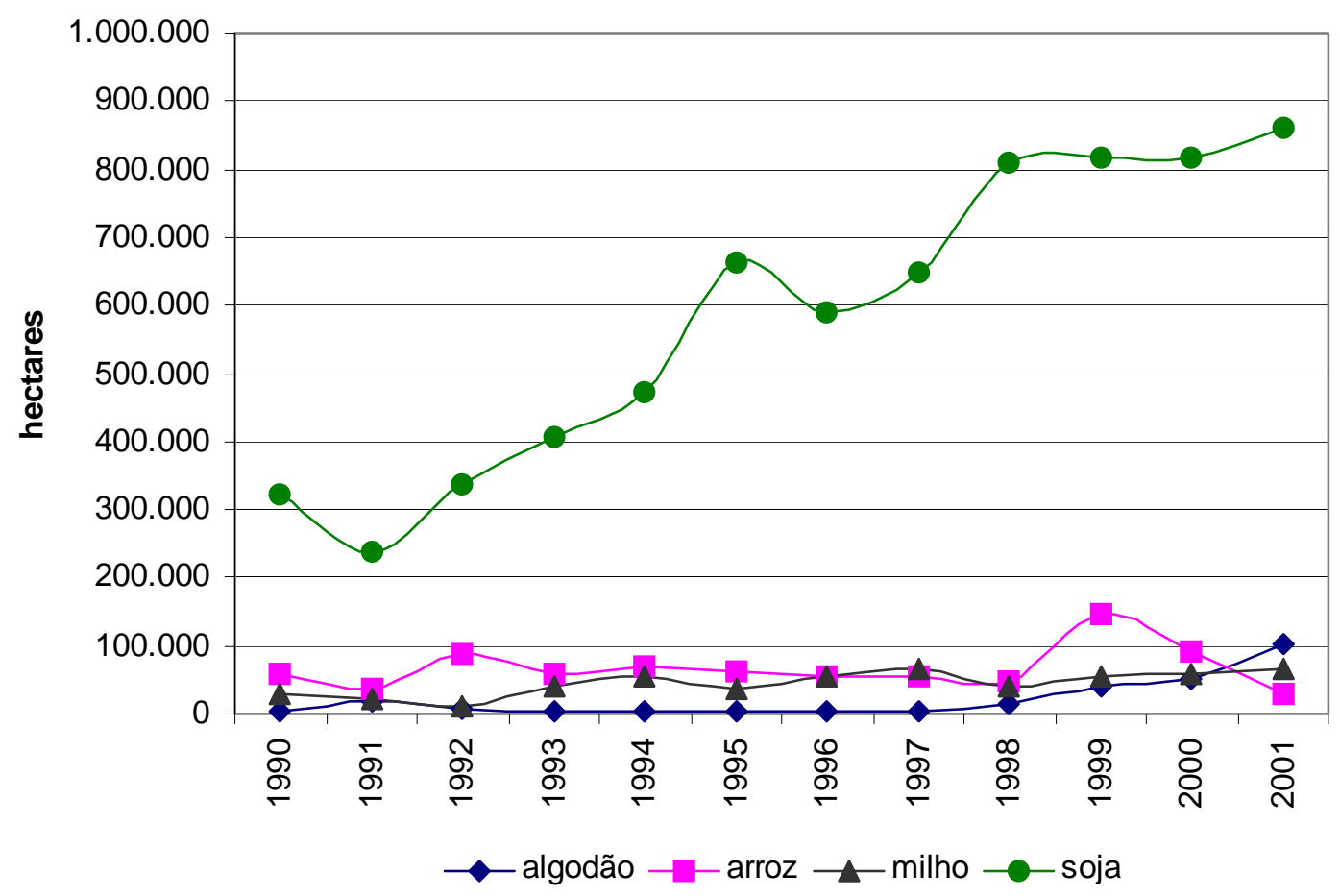

Figura 23 - Evolução da área de algodão, arroz, milho e soja na região oeste do Mato Grosso.

Fonte: IBGE (2003d) 
Apesar da soja ser a cultura mais plantada na região, o algodão é a cultura que apresenta o maior crescimento médio anual. Na Figura 24 pode-se observar, sob a forma de índice, a evolução da área das culturas de interesse na região oeste matogrossense. Apesar da soja ser a grande vedete dos últimos anos, o algodão é a cultura que mais tem crescido; contudo, sua área ainda é bem inferior a da soja.

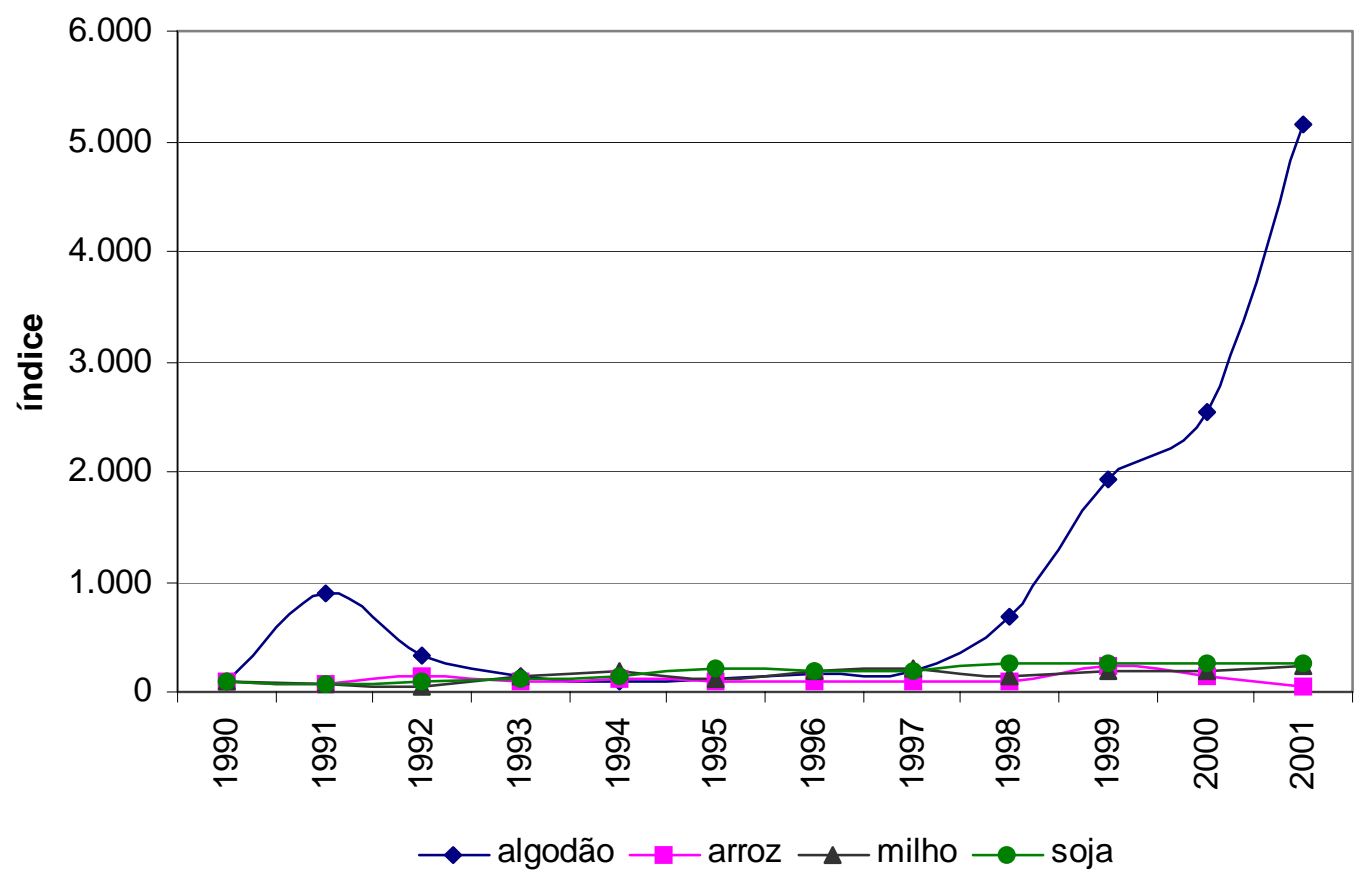

Figura 24 - Índice de área das culturas na região oeste mato-grossense.

Fonte: IBGE (2003d)

\subsubsection{Considerações complementares}

Percebe-se que a cultura do arroz no Mato Grosso foi a que menos cresceu em produção e sofreu redução na área de 1980 a 2001. Em relação às regiões do estudo, houve decréscimo de área e produção no oeste (microrregião de Parecis) e redução de área no leste. As condições em que se cultiva arroz no estado (abertura de área e 
recuperação de pastos) imprimem um caráter secundário para a cultura, com a maioria dos produtores cultivando esse cereal esporadicamente.

O arroz se insere no Mato Grosso de uma forma não muito convencional, pois após o seu cultivo em abertura de área (permanecendo até dois anos na mesma área), é substituído pela cultura da soja, cujo plantio é realizado entre três e seis anos consecutivos, sendo geralmente de três ou quatro anos. Findo o cultivo da soja, o arroz retorna ao sistema com o objetivo de reduzir a incidência de pragas e doenças da soja (principal cultura), completando uma espécie de ciclo de cultivo. Ocorre um comportamento similar a esse, envolvendo a orizicultura e as pastagens. Tal ciclo consiste na utilização do arroz para recuperação dos pastos degradados. A estimativa de degradação dos pastos é difícil devido ao manejo adotado na propriedade, contudo, sempre há áreas a serem recuperadas dada a importância da atividade pecuária no estado. Neste caso, o arroz também permanece por dois anos seguidos na mesma área. Em decorrência desses e de outros fatores já comentados anteriormente, há praticamente um esquecimento da cultura do arroz e de que esta pode gerar boa rentabilidade ao produtor se cultivada com a devida tecnologia. Deveria haver mais variedades de arroz disponíveis para cultivo e disponíveis aos produtores, bem adaptadas ao ecossistema do cerrado e que satisfaçam o desejo dos consumidores por produto longo fino de boa qualidade.

Dados os problemas enfrentados pela orizicultura mato-grossense, torna-se difícil traçar perspectivas quanto ao futuro da atividade no estado devido aos investimentos de instituições de pesquisa, como a Embrapa, e maior entrada de agroindústrias arrozeiras. Lentamente ocorre melhoria no setor, principalmente na década de 90, com o lançamento de variedades mais adaptadas ao cerrado e de maior produtividade, sendo que este avanço veio acompanhado do maior número de agroindústrias arrozeiras no estado. Acredita-se desta forma, que o panorama de cultivo do arroz no estado possa mudar. Contudo, não se pode esperar que no curto prazo a orizicultura cresça de forma acentuada, mas provavelmente não acontecerá no Mato Grosso o que houve com a orizicultura no Estado de Goiás, que era o segundo maior produtor e atualmente nem figura entre os dez maiores produtores. 
Nas regiões norte e central verificou-se o uso da soja como cultura pioneira em pequenas áreas, contudo isso não é representativo e nem significa que há uma tendência de utilização da soja na expansão da fronteira agrícola. Isso aconteceu devido aos elevados preços pagos ao produtor da leguminosa, que acabam compensando um possível prejuízo quanto à quebra de peças das colheitadeiras, visto que a altura da plataforma das mesmas é baixa. Mesmo com o aumento do preço recebido pelo produtor de arroz do Mato Grosso, a elevação dos preços da soja foi maior, estimulando o seu cultivo. Outros fatores como os canais de comercialização mais bem desenvolvidos, melhores possibilidades de financiamento da produção e ser um produto voltado ao mercado externo fazem com que a soja seja a atividade mais preferida pelos produtores do estado.

Visualiza-se na Figura 25 a evolução dos preços reais, deflacionados para setembro de 2003, das culturas do algodão, arroz, milho e soja.

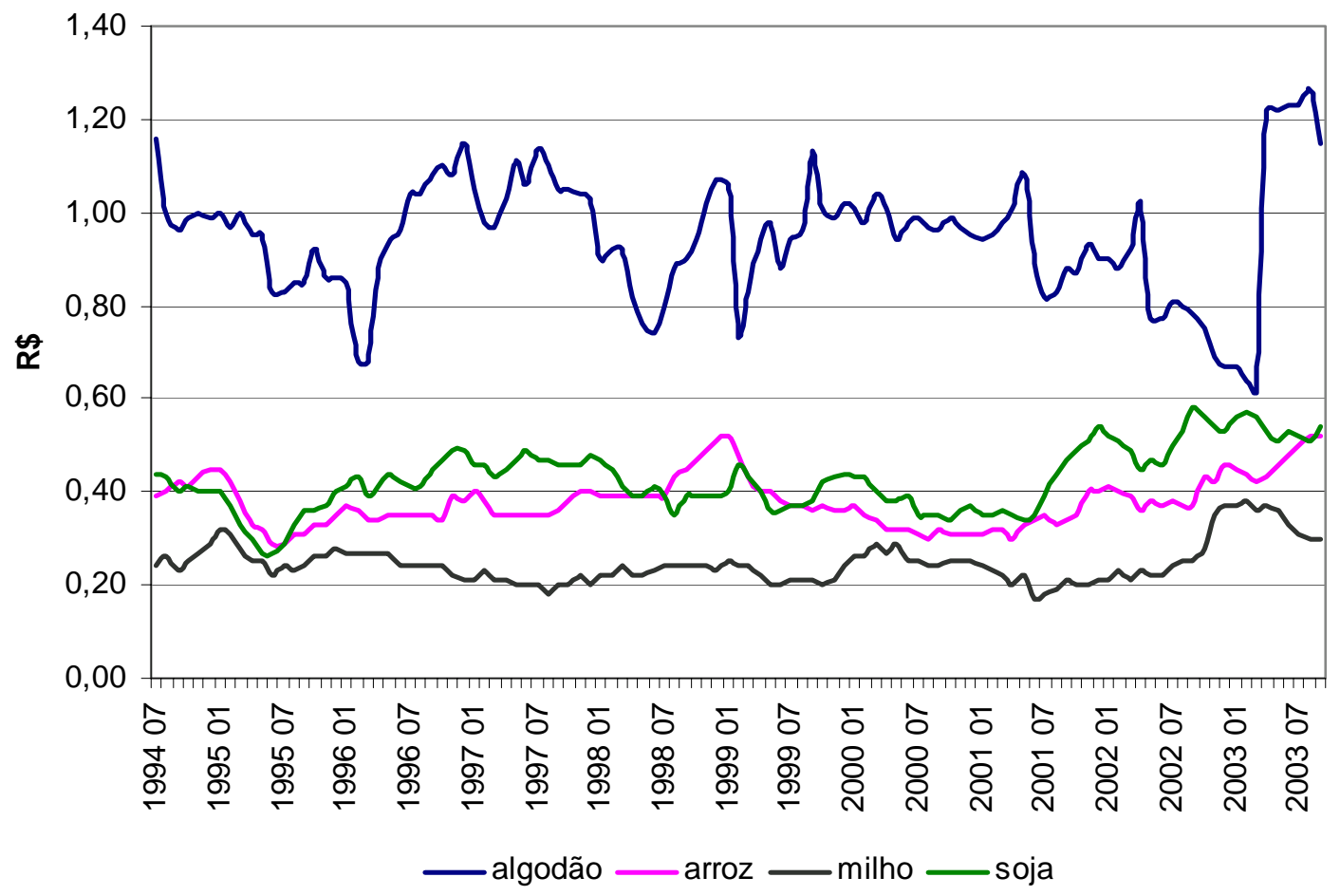

Figura 25 - Preços recebidos pelos produtores de algodão, arroz, milho e soja do Mato Grosso.

Fonte: FGV (2003) 
Percebe-se, na Figura 25, a elevação dos preços recebidos pelos produtores de soja em meados de 2001, coincidindo também com a elevação dos preços do arroz e do milho. Nota-se grande irregularidade nos preços ao produtor de algodão. Observa-se que os preços de arroz eram decrescentes de fevereiro de 1999 até junho de 2001, decorrentes da alta produção em 1998/99 e 1999/00, combinada a elevação dos estoques governamentais em 1999/00 (Tabela 8).

Mesmo com a crescente preocupação mundial no tocante à degradação ambiental, o processo de abertura de áreas ainda é grande, avançando sobre a Amazônia Legal, demonstrando que as medidas de combate ao desmatamento ainda não se tornaram efetivas. Um dos motivos desse desmatamento é a pressão internacional por maior competitividade, o que acaba ocasionando sérios problemas de degradação ambiental, pois buscando redução de custos, a produção de grãos se expande para áreas novas onde o preço da terra e do arrendamento são mais baixos.

A falta de estrutura de secagem e armazenagem dos produtores matogrossenses conferem maiores dificuldades para os mesmos no momento da comercialização, ao contrário dos produtores do Rio Grande do Sul, que possuem essa infra-estrutura e maior organização, controlando o fluxo de arroz de acordo com os preços do mercado. Contudo, o controle da oferta por parte dos produtores do Rio Grande do Sul pode ocasionar malefícios para toda a cadeia produtiva, afetando a sociedade com a possível elevação dos preços ao consumidor, causando pressão inflacionária, a exemplo do que acontece atualmente.

\subsection{Agroindústria}

A agroindústria consiste em um setor que transforma os produtos agrícolas, agregando-lhes valor, diversificando e gerando novos produtos e mercados. Normalmente as empresas desse segmento situam-se próximas aos locais de produção da matéria-prima. 
Foram visitadas agroindústrias da região central de Mato Grosso, mais especificamente de Sinop e da região leste (Primavera do Leste). Foram visitadas também agroindústrias de Rondônia, pois como foi observado anteriormente, a região oeste mantêm relações comerciais com esse estado.

Objetivou-se com o questionário da agroindústria explorar o destino dos produtos, a qualidade da matéria-prima e as perspectivas do mercado de arroz.

Contrariamente à descrição do sistema produtivo, em que se dividiu o estado em quatro regiões, as características pós-fazenda não se distinguem ao ponto de serem realizadas tais subdivisões.

Observa-se que as agroindústrias de Sinop comercializam arroz para diversas localidades do estado, como Cuiabá, Várzea Grande, Rondonópolis, Primavera do Leste e municípios próximos, assim como para outros estados: Minas Gerais (Uberlândia), Paraná, São Paulo (Ourinhos), Goiás (Anápolis), Rio Grande do Sul e para os estados do Nordeste. O arroz negociado para o interior do Nordeste é de baixa qualidade (é um arroz com manchas, classificação tipo 3 ou inferior). As capitais nordestinas são abastecidas com arroz de boa qualidade, cujo maior fornecedor é o Rio Grande do Sul, embora se encontre também marcas de Mato Grosso, com arroz de alta qualidade. A Tabela 14 apresenta a classificação do arroz por tipos. 
Tabela 14. Limites máximos de tolerância de defeitos (\%) para enquadramento do arroz beneficiado polido* em tipo comercial.

\begin{tabular}{|c|c|c|c|c|c|}
\hline \multirow[b]{2}{*}{ Тіро } & \multicolumn{2}{|c|}{ Defeitos graves } & \multirow{2}{*}{$\begin{array}{c}\text { Defeitos gerais } \\
\text { agregados** }\end{array}$} & \multirow{2}{*}{$\begin{array}{c}\text { Total de } \\
\text { quebrados e } \\
\text { quirera }\end{array}$} & \multirow{2}{*}{$\begin{array}{l}\text { Quirera } \\
\text { (máximo) }\end{array}$} \\
\hline & $\begin{array}{c}\text { Matérias estranhas } \\
\text { e impurezas }\end{array}$ & $\begin{array}{c}\text { Mofados e } \\
\text { ardidos }\end{array}$ & & & \\
\hline 1 & 0,25 & 0,25 & 4 & 10 & 0,50 \\
\hline 2 & 0,50 & 0,50 & 8 & 20 & 1,00 \\
\hline 3 & 1,00 & 1,00 & 14 & 30 & 2,00 \\
\hline 4 & 1,50 & 2,00 & 22 & 40 & 3,00 \\
\hline 5 & 2,00 & 4,00 & 34 & 50 & 4,00 \\
\hline
\end{tabular}

Fonte: Castro et al. (1999)

* Há tabelas específicas para as diferentes formas de apresentação do produto: arroz em casca natural; em casca parboilizado; beneficiado integral; beneficiado parboilizado; beneficiado parboilizado integral.

** Os limites máximos admitidos para cada defeito geral são: manchados e picados $12 \%$; amarelos $12 \%$; rajados $10 \%$; gessados $15 \%$.

As agroindústrias de Primavera do Leste vendem o arroz de melhor qualidade para as localidades próximas, Uberlândia e Goiânia. Também nesse caso o arroz de pior qualidade é destinado ao interior do Nordeste. Os compradores goianos preferem o arroz em casca para comercializarem os subprodutos resultantes do beneficiamento. A compra estende-se desde a safra (fev./mar.) até junho, quando se encerra a oferta de Primavera, e a partir daí as agroindústrias goianas compram a matéria-prima do Sul do país.

As agroindústrias do oeste estão em sua maioria localizadas em Sapezal e comercializam arroz para os municípios vizinhos; comercializam também para Rondônia, Acre, Amazonas e exportam para a Bolívia. As agroindústrias de Rondônia (Ji-Paraná e Vilhena) beneficiam boa parte da produção do Mato Grosso, em especial da região oeste. Empreendedores de Comodoro e Campos de Júlio planejam aumentar a 
capacidade de beneficiamento de arroz. Os agentes do segmento agroindustrial acreditam na profissionalização do setor, com o emprego de mais tecnologia, e na abolição do caracter secundário da cultura.

De maneira geral, as agroindústrias preferem o arroz Primavera por possuir melhor qualidade e por atender às exigências do mercado de grão longo fino. A variedade Cirad 141 possui razoáveis atributos culinários, mas necessita de longo tempo pós-colheita para atingir a maturação, o que permite o bom cozimento dos grãos. A qualidade do grão é bastante variável, refletindo as condições de produção, na qual se adota diferentes níveis tecnológicos. Além do mais, problemas de secagem, desuniformidade na maturação dos grãos podem causar manchas. Observou-se inadimplência na comercialização, principalmente quando o produto foi vendido para o Nordeste.

Uma agroindústria de Primavera do Leste diferencia-se das demais por estabelecer contratos de compra e realizar pagamentos de acordo com a qualidade da matéria-prima, pagando ágio no caso de produto superior a um determinado padrão e deságio no caso de produto inferior ao padrão estabelecido.

De acordo com Ferreira et al. (2002b), os agentes do elo atacadista da cadeia produtiva do arroz avaliam negativamente a participação governamental por ela alterar bruscamente o mercado, dificultando a formulação de estratégias por parte das empresas, desestimulando os investimentos no aumento da capacidade de armazenamento e modernização do maquinário de beneficiamento. O Governo, em contrapartida, tem justificativas socioeconômicas para intervir no mercado, garantindo o abastecimento interno e reduzindo o custo da cesta básica para que não haja pressão inflacionária. As agroindústrias, por sua vez, avaliam positivamente a atuação governamental no controle dos estoques, pois as mesmas não carregam consigo os custos e riscos de armazenagem e quando da elevação dos preços adquirem a matéria-prima via leilões da Conab. 


\subsection{Expansão e substituição de culturas}

Antes de se analisar os dados por meio da metodologia "shift-share", salienta-se que a mesma não considera alteração na escala da unidade produtiva. As alterações de área consideradas na metodologia dizem respeito à área da cultura na microrregião e no estado. Utiliza-se a produtividade da terra como "proxy" do progresso tecnológico, refletindo mudanças pela adoção de novos insumos, técnicas de produção e melhoria do capital humano. Silva (1984) argumenta que o ideal seria utilizar os ganhos de produtividade total. Vera Filho \& Tollini (1979) afirmam que a produtividade não está necessariamente associada ao progresso tecnológico, pois processos produtivos menos eficientes podem gerar maiores produtividades.

A análise compreende o período de 1980 a 2000, divididos em subperíodos, a saber: 1980-85, 1985-90, 1990-95, 1995-2000, conforme explicado anteriormente.

As alterações ocorridas na área plantada das culturas analisadas (algodão, arroz, milho e soja) podem ser decompostas nos efeitos escala e substituição, ambos os efeitos são derivados do efeito área, conforme já mencionado anteriormente. O efeito escala mede a variação da área da cultura, resultante da expansão ou redução do sistema de produção. O efeito substituição expressa as modificações na área em decorrência do processo de substituição existente entre as culturas. Vale ressaltar a hipótese de proporcionalidade que há no efeito substituição entre as áreas que são cedidas por determinada cultura e as áreas recebidas por outras culturas dentro do sistema global de produção. Infelizmente não se dispõe de bons dados estatísticos referentes às áreas de pastagens para se realizar o estudo de expansão e substituição de cultura, bem como do crescimento da orizicultura em competição com as pastagens, pois como comentado anteriormente, percebeu-se uma forte relação entre a atividade pecuária e a orizicultura.

Analisando o período de 1980-2000, pode-se observar que o Estado do Mato Grosso teve um efeito escala positivo de 3.311 .874 ha, significando um aumento das áreas das culturas selecionadas (Tabela 15). $\mathrm{O}$ arroz foi a cultura que apresentou o maior efeito escala, entretanto, o efeito substituição foi maior e negativo, resultando em diminuição da área cultivada. Seu efeito substituição foi negativo à taxa média anual de 
14,21\%. O arroz foi a única cultura que cedeu área no período considerado (-2.974.964 ha), sendo que a cultura da soja absorveu $87 \%$ da área total cedida pelo arroz, o algodão incorporou 9\% dessa área e o milho 4\% (Tabela 15).

Em síntese, o arroz foi a cultura que mais sofreu perdas de área devido ao efeito substituição. A soja foi a cultura que mais ganhou área pelo efeito substituição, exceto no subperíodo de 1995-2000. O efeito escala foi positivo para todas as culturas em análise em todos períodos considerados.

Tabela 15. Decomposição do efeito área em efeitos escala e substituição no Mato Grosso, de 1980 a 2000.

\begin{tabular}{cccc}
\hline \multirow{2}{*}{ Culturas } & \multicolumn{3}{c}{ Efeitos (ha) } \\
\cline { 2 - 4 } & Área & Escala & Substituição \\
\hline Algodão & $285.580,00$ & $14.964,88$ & $270.615,12$ \\
Arroz & $-208.003,00$ & $2.766 .961,13$ & $-2.974 .964,13$ \\
Milho & $416.576,33$ & $297.875,20$ & $118.701,13$ \\
Soja & $2.817 .720,33$ & $232.072,45$ & $2.585 .647,88$ \\
Total & $3.311 .873,67$ & $3.311 .873,67$ & 0,00 \\
\hline
\end{tabular}

Fonte: dados da pesquisa.

Verifica-se, no subperíodo (1980-1985), comportamento semelhante ao observado para o período tomado como um todo. No subperíodo 1980-1985 a cultura do arroz sofreu redução da área devido ao efeito substituição (-752.408,05 ha), sendo que a cultura da soja incorporou 85\% da área cedida pelo arroz, o milho 14\% e o algodão 1\%. Observa-se um aumento total de área de 520.985,33 ha no período, passando de 997.295 ha em 1980 para 1.518.281 ha em 1985; aumento de 52\%. Nota-se, na Tabela 16, que o efeito escala do arroz foi de 435.266 ha, correspondendo a 83,5\% do efeito escala total. Isto fornece indícios de que o sistema de produção cresceu em maior parte com o cultivo do arroz que em seqüência foi substituído por outras culturas, principalmente pela soja. 
Tabela 16. Decomposição do efeito área em efeitos escala e substituição no Mato Grosso, de 1980 a 1985.

\begin{tabular}{cccc}
\hline \multirow{2}{*}{ Culturas } & \multicolumn{3}{c}{ Efeitos (ha) } \\
\cline { 2 - 4 } & Área & Escala & Substituição \\
\hline Algodão & $8.576,33$ & $2.354,10$ & $6.222,23$ \\
Arroz & $-317.142,00$ & $435.266,05$ & $-752.408,05$ \\
Milho & $150.491,33$ & $46.858,25$ & $103.633,08$ \\
Soja & $679.059,67$ & $36.506,93$ & $642.552,74$ \\
Total & $520.985,33$ & $520.985,33$ & 0,00 \\
\hline
\end{tabular}

Fonte: dados da pesquisa.

Observa-se, na Tabela 17, uma redução da área de arroz (-92.349 ha) entre 1985 e 1990, provocada pelo efeito substituição (-333.360 ha). Verifica-se também que a cultura do milho teve efeito substituição negativo. Do total de área cedida, o arroz foi responsável por $83,5 \%$ e o milho por $16,5 \%$, sendo que a soja absorveu $92 \%$ da área total cedida.

Tabela 17. Decomposição do efeito área em efeitos escala e substituição no Mato Grosso, de 1985 a 1990.

\begin{tabular}{cccc}
\hline \multirow{2}{*}{ Culturas } & \multicolumn{3}{c}{ Efeitos (ha) } \\
\cline { 2 - 4 } & Área & Escala & Substituição \\
\hline Algodão & $38.491,67$ & $6.109,82$ & $32.381,85$ \\
Arroz & $-92.349,00$ & $241.010,98$ & $-333.359,98$ \\
Milho & $46.533,00$ & $112.172,52$ & $-65.639,52$ \\
Soja & $716.386,33$ & $349.768,68$ & $366.617,66$ \\
Total & $709.062,00$ & $709.062,00$ & 0,00 \\
\hline
\end{tabular}

Fonte: dados da pesquisa. 
Ao contrário dos subperíodos 1980-1985 e 1985-1990, as culturas do algodão, arroz, milho e soja tiveram aumento de área no subperíodo 1990-1995. As culturas do arroz e do algodão cederam 95\% e 5\% de suas áreas, respectivamente, e a soja e o milho incorporaram cada 50\% da área total cedida (152.252,64 ha) (Tabela 18).

Tabela 18. Decomposição do efeito área em efeitos escala e substituição no Mato Grosso, de 1990 a 1995.

\begin{tabular}{cccc}
\hline \multirow{2}{*}{ Culturas } & \multicolumn{3}{c}{ Efeitos (ha) } \\
\cline { 2 - 4 } & Área & Escala & Substituição \\
\hline Algodão & $11.933,67$ & $19.680,74$ & $-7.747,07$ \\
Arroz & $17.184,33$ & $161.689,91$ & $-144.505,57$ \\
Milho & $185.521,00$ & $109.413,20$ & $76.107,80$ \\
Soja & $635.313,67$ & $559.168,82$ & $76.144,84$ \\
Total & $849.952,67$ & $849.952,67$ & 0,00 \\
\hline
\end{tabular}

Fonte: dados da pesquisa.

Da mesma forma que no subperíodo 1990-1995, no subperíodo 1995-2000 as culturas analisadas tiveram aumento de área, destacando-se a soja com um aumento de 786.961 ha (Tabela 19). Vale salientar que a soja e o milho tiveram efeito substituição negativo. Aproximadamente $26 \%$ da área total cedida foi proveniente da sojicultura e $74 \%$ foi proveniente da cultura do milho. A cultura do algodão incorporou 96\% da área cedida e o arroz 4\%.

Tabela 19. Decomposição do efeito área em efeitos escala e substituição no Mato Grosso, de 1995 a 2000.

\begin{tabular}{cccc}
\hline \multirow{2}{*}{ Culturas } & \multicolumn{3}{c}{ Efeitos (ha) } \\
\cline { 2 - 4 } & Área & Escala & Substituição \\
\hline Algodão & $226.578,33$ & $25.422,92$ & $201.155,41$ \\
Arroz & $184.303,67$ & $176.497,17$ & $7.806,50$
\end{tabular}


Tabela 19. Decomposição do efeito área em efeitos escala e substituição no Mato Grosso, de 1995 a 2000.

\begin{tabular}{cccc}
\hline \multirow{2}{*}{ Culturas } & \multicolumn{3}{c}{ Efeitos (ha) } \\
\cline { 2 - 4 } & Área & Escala & Substituição \\
\hline Milho & $34.031,00$ & $189.044,10$ & $-155.013,10$ \\
Soja & $786.960,67$ & $840.909,47$ & $-53.948,81$ \\
Total & $1.231 .873,67$ & $1.231 .873,67$ & 0,00 \\
\hline
\end{tabular}

Fonte: dados da pesquisa.

Percebe-se que os resultados decorrentes da decomposição do efeito área em efeito escala e substituição estão de acordo com os dados apresentados no tópico que tratou da descrição do sistema produtivo, onde é citado que a cultura do arroz entra no sistema para o desbravamento de novas áreas e em seguida ela é substituída pela soja, conforme descrevem Igreja et al. (1995) e Villar \& Ferreira, (2002). No subperíodo 1995-2000, observou-se efeito substituição negativo para a soja, fato inesperado dado o comportamento incorporador de área verificado nos outros subperíodos. O efeito substituição positivo da cultura do algodão era esperado devido ao ganho de área da cultura na segunda metade da década de 90 e às inovações tecnológicas incorporadas por essa cultura.

Deve-se observar os resultados de alteração na área plantada com certa cautela, visto que o estudo não levou em consideração as áreas de pastagens e de matas nativas pela ausência de dados estatísticos para as microrregiões. A exclusão destas áreas pode causar algumas distorções nos resultados.

\subsection{Análise individual das culturas no Estado do Mato Grosso}

Busca-se explicar o comportamento da produção de algodão, arroz, milho e soja no Mato Grosso, analisando distintamente os efeitos área (subdividido em efeito escala e substituição), efeito rendimento e localização geográfica. 
Por se tratar da análise individual das culturas do estado, não é possível calcular o efeito composição da produção, sendo a mudança da produção creditada apenas aos efeitos área, rendimento e localização geográfica, conforme citado anteriormente.

Observa-se na Tabela 20, que expressa a taxa média anual de crescimento das culturas, bem como os efeitos área, rendimento e localização geográfica, que a soja foi a cultura que mais cresceu em produção no período, atingindo uma taxa anual média de crescimento de 24,21\%, com o efeito área positivo de 12,95\% a.a., o efeito substituição positivo de $11,88 \%$ a.a. e o efeito rendimento de 10,81\% a.a.. O arroz foi a cultura que menos cresceu, 2,34\% a.a., sendo responsável por esse baixo crescimento o efeito área negativo (-0,99\% a.a.). Percebe-se que o efeito escala foi o maior no período (13,21\% a.a.), contudo, o efeito substituição foi de -14,21\% a.a.. Esses dados mostram mais uma vez que a cultura do arroz tem sido usada no processo de expansão de novas áreas agrícolas, para posteriormente ser substituída por culturas mais rentáveis, como a soja, por exemplo. Os resultados dos efeitos escala e substituição, sozinhos, não permitem afirmar que o arroz tem sido utilizado na abertura de novas áreas, contudo, aliados ao conhecimento do sistema produtivo, fornecem idéia do comportamento da cultura. O efeito rendimento para o arroz (2,09\% a.a.) foi modesto, comparado ao das outras culturas.

O efeito localização geográfica foi positivo para as culturas do algodão, do arroz e da soja, indicando que a proporção da área total cultivada no estado por cultura cresceu nas regiões que apresentam maiores índices de produtividade. 
Tabela 20. Taxa média anual de crescimento, efeitos área, rendimento e localização geográfica das culturas do algodão, arroz, milho e soja no Mato Grosso, de 1980 a 2000.

\begin{tabular}{|c|c|c|c|c|c|c|}
\hline \multirow[b]{2}{*}{ Culturas } & \multirow{2}{*}{$\begin{array}{l}\text { Tx. anual de } \\
\text { crescimento da } \\
\text { produção (\%) }\end{array}$} & \multicolumn{3}{|c|}{ Efeito área (\%) } & \multirow{2}{*}{$\begin{array}{c}\text { Efeito } \\
\text { rendimento } \\
(\%)\end{array}$} & \multirow{2}{*}{$\begin{array}{c}\text { Efeito } \\
\text { localização } \\
(\%)\end{array}$} \\
\hline & & Total & $\begin{array}{l}\text { Efeito } \\
\text { escala }\end{array}$ & $\begin{array}{c}\text { Efeito } \\
\text { substituição }\end{array}$ & & \\
\hline Algodão & 14,67 & 3,67 & 0,19 & 3,48 & 8,34 & 2,67 \\
\hline Arroz & 2,34 & $-0,99$ & 13,21 & $-14,21$ & 2,09 & 1,24 \\
\hline Milho & 12,26 & 6,25 & 4,47 & 1,78 & 6,04 & $-0,03$ \\
\hline Soja & 24,21 & 12,95 & 1,07 & 11,88 & 10,81 & 0,45 \\
\hline
\end{tabular}

Fonte: dados da pesquisa.

Percebe-se, com as informações da Tabela 20, que o efeito área foi o principal fator explicativo do aumento da produção da soja e do milho, vindo em seguida o fator rendimento. O principal fator explicativo do crescimento da produção do algodão e do arroz foi o rendimento, principalmente na segunda metade da década de 90, conforme será visto mais adiante.

De maneira geral, os efeitos área e rendimento alternaram-se como os principais fatores explicativos da variação da produção das culturas em todos os subperíodos considerados, fato também verificado por Moreira (1996).

As Tabelas 21 a 24 mostram os componentes da taxa anual média de variação da produção nos subperíodos em estudo. 
Tabela 21. Taxa média anual de crescimento, efeitos área, rendimento e localização geográfica das culturas do algodão, arroz, milho e soja no Mato Grosso, de 1980 a 1985.

\begin{tabular}{|c|c|c|c|c|c|c|}
\hline \multirow[b]{2}{*}{ Culturas } & \multirow{2}{*}{$\begin{array}{l}\text { Tx. anual de } \\
\text { crescimento da } \\
\text { produção (\%) }\end{array}$} & \multicolumn{3}{|c|}{ Efeito área (\%) } & \multirow{2}{*}{$\begin{array}{c}\text { Efeito } \\
\text { rendimento } \\
(\%)\end{array}$} & \multirow{2}{*}{$\begin{array}{c}\text { Efeito } \\
\text { localização } \\
\text { (\%) }\end{array}$} \\
\hline & & Total & $\begin{array}{l}\text { Efeito } \\
\text { escala }\end{array}$ & $\begin{array}{c}\text { Efeito } \\
\text { substituição }\end{array}$ & & \\
\hline Algodão & 32,09 & 20,22 & 5,55 & 14,67 & 12,60 & $-0,72$ \\
\hline Arroz & $-8,25$ & $-8,98$ & 12,32 & $-21,30$ & 0,05 & 0,67 \\
\hline Milho & 24,08 & $-10,18$ & $-3,17$ & $-7,01$ & 35,79 & $-1,54$ \\
\hline Soja & 68,72 & $-4,26$ & $-0,23$ & $-4,03$ & 73,86 & $-0,88$ \\
\hline
\end{tabular}

Fonte: dados da pesquisa.

Tabela 22. Taxa média anual de crescimento, efeitos área, rendimento e localização geográfica das culturas do algodão, arroz, milho e soja no Mato Grosso, de 1985 a 1990.

\begin{tabular}{|c|c|c|c|c|c|c|}
\hline \multirow[b]{2}{*}{ Culturas } & \multirow{2}{*}{$\begin{array}{l}\text { Tx. anual de } \\
\text { crescimento da } \\
\text { produção (\%) }\end{array}$} & \multicolumn{3}{|c|}{ Efeito área (\%) } & \multirow{2}{*}{$\begin{array}{c}\text { Efeito } \\
\text { rendimento } \\
(\%)\end{array}$} & \multirow{2}{*}{$\begin{array}{c}\text { Efeito } \\
\text { localização } \\
(\%)\end{array}$} \\
\hline & & Total & $\begin{array}{l}\text { Efeito } \\
\text { escala }\end{array}$ & $\begin{array}{c}\text { Efeito } \\
\text { substituição }\end{array}$ & & \\
\hline Algodão & 32,22 & 19,56 & 3,11 & 16,46 & 11,19 & 1,47 \\
\hline Arroz & $-2,00$ & $-3,72$ & 9,72 & $-13,45$ & 1,24 & 0,49 \\
\hline Milho & 10,89 & 3,12 & 7,52 & $-4,40$ & 3,60 & 4,17 \\
\hline Soja & 15,97 & 13,92 & 6,80 & 7,12 & 2,11 & $-0,06$ \\
\hline
\end{tabular}

Fonte: dados da pesquisa. 
Tabela 23. Taxa média anual de crescimento, efeitos área, rendimento e localização geográfica das culturas do algodão, arroz, milho e soja no Mato Grosso de 1990 a 1995.

\begin{tabular}{|c|c|c|c|c|c|c|}
\hline \multirow[b]{2}{*}{ Culturas } & \multirow{2}{*}{$\begin{array}{c}\text { Tx. anual de } \\
\text { crescimento da } \\
\text { produção (\%) }\end{array}$} & \multicolumn{3}{|c|}{ Efeito área (\%) } & \multirow{2}{*}{$\begin{array}{c}\text { Efeito } \\
\text { rendimento } \\
(\%)\end{array}$} & \multirow{2}{*}{$\begin{array}{c}\text { Efeito } \\
\text { localização } \\
(\%)\end{array}$} \\
\hline & & Total & $\begin{array}{l}\text { Efeito } \\
\text { escala }\end{array}$ & $\begin{array}{c}\text { Efeito } \\
\text { substituição }\end{array}$ & & \\
\hline Algodão & 3,99 & 4,27 & 7,05 & $-2,77$ & 0,14 & $-0,43$ \\
\hline Arroz & 5,63 & 0,72 & 6,82 & $-6,09$ & 4,40 & 0,51 \\
\hline Milho & 13,33 & 9,92 & 5,85 & 4,07 & 2,03 & 1,38 \\
\hline Soja & 10,50 & 7,03 & 6,19 & 0,84 & 3,38 & 0,09 \\
\hline
\end{tabular}

Fonte: dados da pesquisa.

Tabela 24. Taxa média anual de crescimento, efeitos área, rendimento e localização geográfica das culturas do algodão, arroz, milho e soja no Mato Grosso, de 1995 a 2000.

\begin{tabular}{|c|c|c|c|c|c|c|}
\hline \multirow[b]{2}{*}{ Culturas } & \multirow{2}{*}{$\begin{array}{l}\text { Tx. anual de } \\
\text { crescimento da } \\
\text { produção (\%) }\end{array}$} & \multicolumn{3}{|c|}{ Efeito área (\%) } & \multirow{2}{*}{$\begin{array}{c}\text { Efeito } \\
\text { rendimento } \\
(\%)\end{array}$} & \multirow{2}{*}{$\begin{array}{c}\text { Efeito } \\
\text { localização } \\
(\%)\end{array}$} \\
\hline & & Total & $\begin{array}{l}\text { Efeito } \\
\text { escala }\end{array}$ & $\begin{array}{c}\text { Efeito } \\
\text { substituição }\end{array}$ & & \\
\hline Algodão & 66,72 & 20,04 & 2,25 & 17,79 & 21,85 & 24,83 \\
\hline Arroz & 15,48 & 6,14 & 5,88 & 0,26 & 7,57 & 1,76 \\
\hline Milho & 1,86 & 1,39 & 7,71 & $-6,32$ & 1,00 & $-0,53$ \\
\hline Soja & 10,09 & 6,12 & 6,54 & $-0,42$ & 4,00 & $-0,03$ \\
\hline
\end{tabular}

Fonte: dados da pesquisa.

O comportamento das taxas de crescimento da produção das culturas consideradas variaram bastante nos subperíodos analisados. Somente a cultura do arroz apresentou taxa de crescimento negativa da produção na década de 1980. Já na década de 1990, todas as culturas apresentaram taxa anual de crescimento da produção positivo. 


\section{Algodão}

A cultura do algodão apresentou taxa anual de crescimento de 14,67\% no período de 1980 a 2000, destacando-se o aumento da produtividade de 8,34\% a.a. e o aumento da área (3,67\% a.a.). O efeito localização geográfica foi o maior entre as culturas analisadas para o período considerado como um todo (2,67\% a.a.) (Tabela 20).

O algodão apresentou um grande crescimento da produção no subperíodo 1980-1985 (32,09\% a.a.), tendo como fator explicativo o efeito área (20,22\% a.a.) e o efeito rendimento (12,6\% a.a.) (Tabela 21$)$. O efeito localização foi negativo (-0,72\% a.a.). Moreira (1996) verificou, para o Rio Grande do Norte, que o efeito área do algodão foi negativo nesse mesmo período.

No subperíodo de 1985-1990, a taxa de crescimento da produção foi de 32,22\% a.a., tendo-se verificado aumento da área plantada e de rendimento para a cultura. O efeito localização foi de 1,47\% ao ano (Tabela 22).

Entre os anos de 1990 e 1995, a taxa de crescimento da produção do algodão foi de 3,99\% a.a., mesmo com a área crescendo à taxa de 4,27\% a.a.. O efeito rendimento contribuiu para o aumento da produção com apenas 0,14\% a.a. e o efeito localização foi negativo (-0,43\% a.a.). Verifica-se, neste período, que o algodão foi substituído por outras culturas à taxa média de -2,77\% ao ano (Tabela 23). A redução no crescimento da produção pode ter sido causada por problemas climáticos e por pragas (bicudo do algodoeiro), que no quinqüênio anterior dizimaram muitas lavouras algodoeiras no Nordeste brasileiro.

Visualiza-se, na Tabela 24, que a taxa de crescimento da cultura do algodão foi de 66,72\% a.a. no período de 1995 a 2000, devendo-se ao efeito localização (24,83\% a.a.), ao efeito rendimento de 21,85\% a.a. e ao efeito área de 20,04\% a.a., destacando-se o efeito substituição de 17,79\% a.a.. Desenvolveram-se neste período tecnologias de produção que permitiram melhor controle do bicudo do algodoeiro, além de variedades mais produtivas e resistentes ao ataque do inseto. 


\section{Arroz}

A taxa de crescimento da produção de arroz de 1980 a 1985 foi negativa, (8,25\% a.a.), explicado pela retração da área cultivada (-8,98\% a.a.) devido principalmente ao efeito substituição negativo (-21,3\% a.a.). O pequeno crescimento da produtividade (0,05\% a.a.) e o efeito localização de apenas 0,67\% a.a. contribuíram para a redução da produção (Tabela 21).

No subperíodo de 1985 a 1990 foi observada taxa negativa de crescimento da produção de arroz (-2,0\% a.a.), e mais uma vez o efeito área negativo foi preponderante para explicar essa redução, pois o efeito rendimento e localização geográfica explicaram pouco na variação da produção de arroz. O efeito substituição foi novamente marcante no período (-13,45\% a.a.). O efeito escala do arroz foi o maior entre as culturas, contudo, não foi suficiente para reverter a queda na produção (Tabela 22).

Visualiza-se, na Tabela 23 (subperíodo 1990-1995), o aumento na produção

de arroz à taxa de 5,63\% ao ano, tendo como principal fator explicativo o rendimento (4,4\% a.a.), enquanto que o efeito área foi de apenas $0,72 \%$ a.a.. Apesar do crescimento da área cultivada, o arroz continua sofrendo substituição, desta vez à taxa de -6,09\% a.a.; o efeito escala foi de 6,82\% a.a..

A cultura do arroz teve uma taxa de crescimento de $15,48 \%$ a.a. no período de 1995 a 2000. O efeito rendimento foi o maior responsável pelo bom desempenho da produção, tendo um aumento de $7,57 \%$ ao ano. O efeito área foi de 6,14\% a.a., destacando-se o efeito escala (5,88\% a.a.); desta vez a cultura do arroz incorporou 176.497 ha, à taxa de 0,26\% a.a.. O efeito localização geográfica foi de 1,76\% a.a., indicando que a maior parte da produção ocorreu em regiões de maior produtividade. $\mathrm{O}$ desenvolvimento de novas variedades mais adaptadas ao cerrado e resistentes a pragas e a doenças foram os principais responsáveis ao aumento da produtividade do arroz no Mato Grosso.

Vale salientar que por força da metodologia utilizada emprega-se o termo substituição como resultado de perda de área devido a maior expansão de área de outra 
cultura, mas como comentado anteriormente, acontece uma espécie de ciclo em que o arroz inicia o cultivo e é substituído temporariamente pela soja ou pastagem e depois retorna ao sistema, não caracterizando a real substituição de uma lavoura por outra e sem uma alternância.

\section{Milho}

Analisando o período de 1980 a 2000, verifica-se que a taxa de crescimento do milho foi de 12,26\% a.a., sendo a metade desse valor devido ao efeito área. A produtividade cresceu à taxa de 6,04\% a.a. e o efeito localização foi de -0,03\% ao ano (Tabela 20).

Visualiza-se, na Tabela 21, o crescimento da produção à taxa de 24,08\% a.a. de 1980 a 1985. O principal componente explicativo desse crescimento foi o efeito rendimento, de 35,79\% a.a.. O crescimento da produção poderia ter sido maior se não fosse a participação negativa do efeito área na explicação da produção (-10,18\% a.a.). O efeito localização foi $-1,54 \%$ ao ano.

O crescimento da produção entre 1985 e 1990 ocorreu à taxa de 10,89\% a.a., o efeito área foi de 3,12\% a.a.. O efeito rendimento cresceu à taxa de 3,6\% a.a., sendo essa taxa bem menor do que a observada no subperíodo anterior. O efeito localização foi de 4,17\% a.a.. (Tabela 22).

A produção do milho cresceu à taxa de 13,33\% a.a. no subperíodo de 1990 a 1995, tendo como principal fator explicativo o efeito área, com uma taxa de crescimento de 9,92\% a.a.; o efeito rendimento foi de 2,03\% a.a. e o efeito localização geográfica de 1,38\% a.a. (Tabela 23).

O menor crescimento da produção observado na cultura do arroz foi no período de 1995 a 2000, aumento à taxa de 1,86\% a.a.. O efeito área foi de 1,39\% a.a. e o efeito rendimento e localização foram 1,0\% a.a. e -0,53\% a.a., respectivamente. $\mathrm{O}$ milho e a soja cederam área neste período, contudo, a parcela do efeito escala na explicação da produção de milho foi maior que o efeito substituição negativo (Tabela 24). 


\section{Soja}

Visualiza-se, na Tabela 21, o grande crescimento da produção de soja (68,72\% a.a.), aumentando de 112.167 t em 1980 para 1.533.383 t em 1985. O principal fator explicativo para a elevação da produção foi o rendimento, que aumentou à taxa de 73,86\% a.a.. Na contramão do crescimento da produção de soja, tem-se o efeito área ($4,26 \%$ a.a.) e o efeito localização (-0,88\%a.a.).

A taxa de crescimento da produção entre os anos 1985 e 1990 foi de 15,97\% a.a., com a área crescendo à taxa de 13,92\% a.a. devido aos efeitos escala (6,8\% a.a.) e substituição (7,12\% a.a.). O efeito rendimento, que no subperíodo anterior foi o principal responsável pelo aumento da produção de soja, neste subperíodo foi de 2,11\% a.a., enquanto o efeito localização foi de $-0,06 \%$ a.a. (Tabela 22).

No subperíodo 1990-1995 observou-se comportamento semelhante ao subperíodo 1985-1990. A taxa de crescimento da produção foi de 10,5\% a.a., os efeitos área, rendimento e localização foram 7,03\% a.a., 3,38\% a.a. e 0,09\% a.a., respectivamente (Tabela 23). O subperíodo seguinte (1995-2000) também apresentou o mesmo padrão, ou seja, o efeito área foi o principal fator explicativo da produção (6,12\% a.a), mesmo apresentando efeito substituição negativo, conforme visto na Tabela 19. O crescimento da produtividade foi de $4,0 \%$ a.a. e o efeito localização foi $-0,03 \%$ ao ano.

Em suma, o principal componente explicativo da produção da soja em todo o período foi o efeito área, destacando-se o efeito substituição positivo. A cultura do milho também teve o efeito área como principal componente explicativo do crescimento da produção, no entanto, decompondo este efeito percebe-se que o efeito escala foi mais importante que o efeito substituição. As culturas do algodão e do arroz tiveram o efeito rendimento como principal componente explicativo do crescimento da produção. Vale destacar que a cultura do arroz teve efeito área negativo, sobretudo pelo efeito substituição, confirmando o caracter secundário da cultura no estado. 


\subsection{Análise do conjunto de culturas por microrregião}

A análise do conjunto de culturas em cada microrregião é realizada com base no valor da produção, mensurando-se os efeitos área, rendimento e composição. Em função de se ter que agregar os produtos resultantes das atividades agrícolas de interesse, utiliza-se o valor da produção como representativa de produção do conjunto de culturas.

Quase todas as microrregiões do Mato Grosso apresentaram taxa positiva de crescimento do valor da produção entre os anos de 1980 e 2000, destacando-se a microrregião de Sinop (39,73\% a.a.), Alta Floresta (26,85\% a.a.), Canarana (26,69\% a.a.), Alto Teles Pires (23,95\% a.a.) e Colíder (21,98\% а.а.).

A maioria das microrregiões apresentou taxa de crescimento do valor da produção mais alta no subperíodo 1980-1985, exceção feita às microrregiões: Médio Araguaia, Tangará da Serra, Jauru e Alto Paraguai. Não há informações para a MRH de Primavera do Leste por causa da inexistência de dados referentes à década de 80 .

Observa-se que no período de 1980 a 2000 o principal fator explicativo da variação do valor da produção da maioria das microrregiões foi o efeito rendimento, seguido pelo efeito área e, por último, tem-se o efeito composição. O efeito área foi mais marcante na década de 1980 na maioria das microrregiões. O principal efeito explicativo do crescimento do valor da produção na maioria das microrregiões no subperíodo 19901995 foi o efeito rendimento e de 1995 a 2000 foi a área. Verifica-se que ao longo do período analisado ocorrem variações nos principais indicadores de crescimento do valor da produção nas microrregiões.

Visualiza-se nas Tabelas 25 a 29, para diversos períodos, a decomposição da taxa média de crescimento do valor da produção em efeitos área, rendimento, composição e localização para o conjunto de culturas das microrregiões de interesse e do Estado do Mato Grosso como um todo. 
Tabela 25. Decomposição da taxa média anual de crescimento do valor da produção das microrregiões e do estado, em efeitos explicativos no período de 1980 a 2000.

\begin{tabular}{|c|c|c|c|c|c|}
\hline Microrregião/Estado & $\begin{array}{l}\text { Tx. anual de } \\
\text { crescimento da } \\
\text { produção (\%) }\end{array}$ & $\begin{array}{l}\text { Efeito } \\
\text { área } \\
(\%)\end{array}$ & $\begin{array}{c}\text { Efeito } \\
\text { rendimento } \\
(\%)\end{array}$ & $\begin{array}{c}\text { Efeito } \\
\text { composição } \\
(\%)\end{array}$ & $\begin{array}{c}\text { Efeito } \\
\text { localização } \\
\text { (\%) }\end{array}$ \\
\hline Aripuanã & 18,12 & 8,17 & 3,91 & 6,03 & - \\
\hline Alta Floresta & 26,85 & 5,13 & 21,48 & 0,25 & - \\
\hline Colíder & 21,98 & 3,37 & 18,12 & 0,49 & - \\
\hline Parecis & 18,80 & 7,46 & 6,37 & 4,98 & - \\
\hline Arinos & 18,88 & 9,06 & 6,79 & 3,03 & - \\
\hline Alto Teles Pires & 23,95 & 10,29 & 10,61 & 3,05 & - \\
\hline Sinop & 39,73 & 3,94 & 32,29 & 3,50 & - \\
\hline Paranatinga & 18,74 & 3,30 & 14,31 & 1,13 & - \\
\hline Norte Araguaia & 6,87 & 4,85 & 2,60 & $-0,58$ & - \\
\hline Canarana & 26,69 & 1,34 & 16,24 & 9,11 & - \\
\hline Médio Araguaia & $-10,79$ & $-11,36$ & 0,38 & 0,19 & - \\
\hline Alto Guaporé & $-0,38$ & $-1,89$ & 1,16 & 0,36 & - \\
\hline Tangará da Serra & 5,95 & 1,30 & 3,66 & 0,98 & - \\
\hline Jauru & $-2,28$ & $-3,36$ & 0,75 & 0,33 & - \\
\hline Alto Paraguai & 7,23 & 2,13 & 5,15 & $-0,05$ & - \\
\hline Rosário Oeste & $-4,19$ & $-5,10$ & 0,51 & 0,40 & - \\
\hline Cuiabá & $-6,14$ & $-7,23$ & 0,49 & 0,60 & - \\
\hline Alto Pantanal & $-6,63$ & $-7,16$ & 0,59 & $-0,07$ & - \\
\hline Primavera do Leste & - & - & - & - & - \\
\hline Tesouro & 9,51 & 2,30 & 2,63 & 4,58 & - \\
\hline Rondonópolis & 9,59 & 1,73 & 2,80 & 5,06 & - \\
\hline Alto Araguaia & 12,55 & 4,06 & 4,97 & 3,52 & - \\
\hline Estado & 13,14 & 4,04 & 3,83 & 4,56 & 0,72 \\
\hline
\end{tabular}

Fonte: dados da pesquisa. 
Tabela 26. Decomposição da taxa média anual de crescimento do valor da produção das microrregiões e do estado, em efeitos explicativos no período de 1980 a 1985.

\begin{tabular}{|c|c|c|c|c|c|}
\hline Microrregião/Estado & $\begin{array}{l}\text { Tx. anual de } \\
\text { crescimento da } \\
\text { produção (\%) }\end{array}$ & $\begin{array}{l}\text { Efeito } \\
\text { área } \\
(\%)\end{array}$ & $\begin{array}{c}\text { Efeito } \\
\text { rendimento } \\
(\%)\end{array}$ & $\begin{array}{c}\text { Efeito } \\
\text { composição } \\
(\%)\end{array}$ & $\begin{array}{c}\text { Efeito } \\
\text { localização } \\
\text { (\%) }\end{array}$ \\
\hline Aripuanã & 37,16 & 28,97 & 9,98 & $-1,79$ & - \\
\hline Alta Floresta & 92,51 & 30,38 & 60,87 & 1,27 & - \\
\hline Colíder & 93,56 & 41,13 & 75,54 & $-23,11$ & - \\
\hline Parecis & 29,01 & 16,63 & $-4,16$ & 16,54 & - \\
\hline Arinos & 38,41 & 48,56 & $-11,27$ & 1,12 & - \\
\hline Alto Teles Pires & 31,39 & 18,66 & $-2,76$ & 15,49 & - \\
\hline Sinop & 129,38 & 25,58 & 94,74 & 9,06 & - \\
\hline Paranatinga & 50,69 & 15,14 & 35,14 & 0,40 & - \\
\hline Norte Araguaia & 19,45 & 16,13 & 3,03 & 0,28 & - \\
\hline Canarana & 71,62 & 6,52 & 47,86 & 17,23 & - \\
\hline Médio Araguaia & $-24,20$ & $-25,77$ & $-0,60$ & 2,17 & - \\
\hline Alto Guaporé & 17,53 & 19,89 & $-3,27$ & 0,91 & - \\
\hline Tangará da Serra & $-0,10$ & $-2,72$ & 1,01 & 1,61 & - \\
\hline Jauru & 1,29 & 2,91 & $-0,64$ & $-0,98$ & - \\
\hline Alto Paraguai & $-0,52$ & $-3,33$ & $-1,22$ & 4,03 & - \\
\hline Rosário Oeste & 10,55 & 5,99 & 1,02 & 3,54 & - \\
\hline Cuiabá & 5,99 & $-0,46$ & 0,72 & 5,73 & - \\
\hline Alto Pantanal & 2,67 & 5,72 & $-3,78$ & 0,73 & - \\
\hline Primavera do Leste & - & - & - & - & - \\
\hline Tesouro & 19,45 & 7,36 & $-0,05$ & 12,74 & - \\
\hline Rondonópolis & 17,46 & 4,98 & 2,85 & 9,63 & - \\
\hline Alto Araguaia & 28,97 & 15,06 & 2,95 & 10,96 & - \\
\hline Estado & 17,60 & 7,36 & 1,98 & 6,55 & 1,71 \\
\hline
\end{tabular}

Fonte: dados da pesquisa. 
Tabela 27. Decomposição da taxa média anual de crescimento do valor da produção das microrregiões e do estado, em efeitos explicativos no período de 1985 a 1990.

\begin{tabular}{|c|c|c|c|c|c|}
\hline Microrregião/Estado & $\begin{array}{l}\text { Tx. anual de } \\
\text { crescimento da } \\
\text { produção (\%) }\end{array}$ & $\begin{array}{l}\text { Efeito } \\
\text { área } \\
(\%)\end{array}$ & $\begin{array}{c}\text { Efeito } \\
\text { rendimento } \\
(\%)\end{array}$ & $\begin{array}{c}\text { Efeito } \\
\text { composição } \\
(\%)\end{array}$ & $\begin{array}{c}\text { Efeito } \\
\text { localização } \\
\text { (\%) }\end{array}$ \\
\hline Aripuanã & 12,61 & 10,17 & $-3,34$ & 5,78 & - \\
\hline Alta Floresta & 4,50 & 7,40 & $-3,67$ & 0,77 & - \\
\hline Colíder & 0,12 & $-5,85$ & 1,87 & 4,10 & - \\
\hline Parecis & 18,52 & 15,65 & 1,67 & 1,21 & - \\
\hline Arinos & 7,71 & 2,07 & 2,26 & 3,38 & - \\
\hline Alto Teles Pires & 30,73 & 26,20 & 2,10 & 2,42 & - \\
\hline Sinop & 9,76 & 6,19 & 0,31 & 3,26 & - \\
\hline Paranatinga & 7,43 & 1,10 & 5,74 & 0,58 & - \\
\hline Norte Araguaia & 6,28 & 8,09 & $-1,61$ & $-0,20$ & - \\
\hline Canarana & 20,98 & 14,24 & 4,40 & 2,34 & - \\
\hline Médio Araguaia & 0,36 & $-2,48$ & 2,90 & $-0,06$ & - \\
\hline Alto Guaporé & $-16,82$ & $-17,65$ & 0,01 & 0,81 & - \\
\hline Tangará da Serra & 18,10 & 10,66 & 5,68 & 1,76 & - \\
\hline Jauru & 5,66 & $-0,62$ & 1,26 & 5,03 & - \\
\hline Alto Paraguai & 5,39 & 1,78 & 0,72 & 2,89 & - \\
\hline Rosário Oeste & $-5,68$ & $-8,30$ & 1,36 & 1,26 & - \\
\hline Cuiabá & $-28,45$ & $-27,65$ & 0,17 & $-0,97$ & - \\
\hline Alto Pantanal & $-12,90$ & $-14,73$ & $-0,31$ & 2,14 & - \\
\hline Primavera do Leste & - & - & - & - & - \\
\hline Tesouro & $-3,81$ & $-6,47$ & 1,53 & 1,13 & - \\
\hline Rondonópolis & 4,75 & 1,69 & 1,89 & 1,17 & - \\
\hline Alto Araguaia & 6,12 & 1,97 & 3,40 & 0,75 & - \\
\hline Estado & 11,24 & 7,46 & 0,43 & 4,98 & $-1,64$ \\
\hline
\end{tabular}

Fonte: dados da pesquisa. 
Tabela 28. Decomposição da taxa média anual de crescimento do valor da produção das microrregiões e do estado, em efeitos explicativos no período de 1990 a 1995.

\begin{tabular}{|c|c|c|c|c|c|}
\hline Microrregião/Estado & $\begin{array}{l}\text { Tx. anual de } \\
\text { crescimento da } \\
\text { produção (\%) }\end{array}$ & $\begin{array}{l}\text { Efeito } \\
\text { área } \\
(\%)\end{array}$ & $\begin{array}{c}\text { Efeito } \\
\text { rendimento } \\
(\%)\end{array}$ & $\begin{array}{c}\text { Efeito } \\
\text { composição } \\
(\%)\end{array}$ & $\begin{array}{c}\text { Efeito } \\
\text { localização } \\
\text { (\%) }\end{array}$ \\
\hline Aripuanã & 4,60 & $-0,57$ & 4,50 & 0,68 & - \\
\hline Alta Floresta & 15,42 & 7,00 & 7,64 & 0,78 & - \\
\hline Colíder & $-2,89$ & $-2,71$ & 0,10 & $-0,28$ & - \\
\hline Parecis & 14,18 & 9,51 & 4,79 & $-0,11$ & - \\
\hline Arinos & 9,23 & 2,04 & 4,66 & 2,53 & - \\
\hline Alto Teles Pires & 16,45 & 13,63 & 4,80 & $-1,98$ & - \\
\hline Sinop & 12,02 & 5,23 & 7,88 & $-1,10$ & - \\
\hline Paranatinga & 8,86 & 8,83 & 1,45 & $-1,42$ & - \\
\hline Norte Araguaia & $-5,41$ & $-6,65$ & 0,79 & 0,44 & - \\
\hline Canarana & 10,94 & 3,67 & 6,08 & 1,19 & - \\
\hline Médio Araguaia & $-10,94$ & $-12,00$ & 1,42 & $-0,36$ & - \\
\hline Alto Guaporé & 6,51 & 3,15 & 4,05 & $-0,68$ & - \\
\hline Tangará da Serra & 3,24 & $-0,78$ & 2,45 & 1,57 & - \\
\hline Jauru & 0,26 & $-2,23$ & 0,33 & 2,17 & - \\
\hline Alto Paraguai & 9,61 & 4,50 & 3,68 & 1,42 & - \\
\hline Rosário Oeste & $-19,06$ & $-16,71$ & $-1,98$ & $-0,38$ & - \\
\hline Cuiabá & $-3,51$ & $-4,87$ & 2,65 & $-1,28$ & - \\
\hline Alto Pantanal & $-3,09$ & $-6,71$ & 1,48 & 2,14 & - \\
\hline Primavera do Leste & 7,52 & 5,62 & 2,29 & $-0,40$ & - \\
\hline Tesouro & 12,39 & 9,17 & 3,06 & 0,16 & - \\
\hline Rondonópolis & 6,75 & 4,83 & 2,03 & $-0,10$ & - \\
\hline Alto Araguaia & 4,32 & 3,75 & 0,59 & $-0,02$ & - \\
\hline Estado & 10,00 & 6,25 & 3,30 & $-0,27$ & 0,72 \\
\hline
\end{tabular}

Fonte: dados da pesquisa. 
Tabela 29. Decomposição da taxa média anual de crescimento do valor da produção das microrregiões e do estado, em efeitos explicativos no período de 1995 a 2000.

\begin{tabular}{|c|c|c|c|c|c|}
\hline Microrregião/Estado & $\begin{array}{c}\text { Tx. anual de } \\
\text { crescimento da } \\
\text { produção (\%) }\end{array}$ & $\begin{array}{c}\text { Efeito } \\
\text { área } \\
(\%)\end{array}$ & $\begin{array}{c}\text { Efeito } \\
\text { rendimento } \\
(\%)\end{array}$ & $\begin{array}{c}\text { Efeito } \\
\text { composição } \\
(\%)\end{array}$ & $\begin{array}{c}\text { Efeito } \\
\text { localização } \\
(\%)\end{array}$ \\
\hline Aripuanã & 20,47 & 13,96 & 1,50 & 5,01 & - \\
\hline Alta Floresta & 11,50 & 2,99 & 7,72 & 0,80 & - \\
\hline Colíder & 17,64 & 2,37 & 12,41 & 2,86 & - \\
\hline Parecis & 14,10 & 7,80 & 3,24 & 3,07 & - \\
\hline Arinos & 22,66 & 13,20 & 6,36 & 3,10 & - \\
\hline Alto Teles Pires & 18,00 & 10,77 & 5,26 & 1,97 & - \\
\hline Sinop & 35,16 & 23,01 & 7,93 & 4,22 & - \\
\hline Paranatinga & 12,82 & 4,36 & 7,24 & 1,22 & - \\
\hline Norte Araguaia & 8,62 & 5,41 & 3,20 & 0,02 & - \\
\hline Canarana & 11,86 & 2,39 & 4,54 & 4,93 & - \\
\hline Médio Araguaia & $-6,51$ & $-9,16$ & 1,51 & 1,14 & - \\
\hline Alto Guaporé & $-5,40$ & $-8,77$ & 4,51 & $-1,13$ & - \\
\hline Tangará da Serra & 3,44 & 0,18 & 4,24 & $-0,97$ & - \\
\hline Jauru & $-15,02$ & $-14,49$ & 4,53 & $-5,06$ & - \\
\hline Alto Paraguai & 15,04 & 9,21 & 6,61 & $-0,79$ & - \\
\hline Rosário Oeste & $-0,15$ & $-3,77$ & 0,55 & 3,06 & - \\
\hline Cuiabá & 6,06 & $-0,43$ & 2,38 & 4,11 & - \\
\hline Alto Pantanal & $-12,31$ & $-12,62$ & 4,76 & $-4,45$ & - \\
\hline Primavera do Leste & 12,58 & 2,38 & 3,29 & 6,90 & - \\
\hline Tesouro & 11,38 & 4,93 & 4,17 & 2,28 & - \\
\hline Rondonópolis & 9,82 & 0,54 & 3,33 & 5,95 & - \\
\hline Alto Araguaia & 12,39 & 4,95 & 3,99 & 3,44 & - \\
\hline Estado & 13,88 & 6,07 & 4,28 & 3,52 & 0,01 \\
\hline
\end{tabular}

Fonte: dados da pesquisa. 


\section{Aripuanã}

Analisando os dados da microrregião de Aripuanã nos anos de 1980 a 2000, verifica-se alta taxa de crescimento do valor da produção $(18,12 \%$ a.a.), sendo o efeito área (8,17\% a.a.) o maior responsável por esse aumento, seguido pelo efeito composição (6,03\% a.a.).

Visualiza-se, na Tabela 26, que Aripuanã apresentou crescimento médio do valor da produção de 37,16\% a.a., sendo que o efeito área representou 78\% desse crescimento. O efeito rendimento foi de 9,98\% a.a. e o efeito composição foi $-1,79 \%$ a.a.. A cultura do arroz foi a única que perdeu área no subperíodo.

A taxa de crescimento do valor da produção entre os anos de 1985 e 1990 foi de 12,61\% a.a., sendo o efeito área de 10,17\% a.a. e o efeito composição de 5,78\% a.a.. O efeito rendimento foi negativo $(-3,34 \%$ a.a.). A taxa de crescimento do valor da produção no subperíodo 1990-1995 foi de 4,60\% a.a., com o principal fator explicativo sendo o rendimento de (4,50\% a.a.). O efeito área foi -0,57\% ao ano.

O efeito área foi o principal responsável pelo crescimento do valor da produção no subperíodo 1995-2000, representando 13,96\% a.a.. Nesse período, as culturas do algodão, arroz, milho e soja expandiram suas áreas. Os efeitos composição e rendimento foram 5,01\% a.a. e 1,50\% a.a., respectivamente.

\section{Alta Floresta}

A microrregião de Alta Floresta apresentou a segunda maior taxa de crescimento do valor da produção (26,85\% a.a.), destacando-se o grande aumento da produtividade (21,48\% a.a.); o efeito área foi de 5,13\% a.a. e o efeito composição de 0,25\% a.a. (Tabela 25).

A microrregião de Alta Floresta foi a que apresentou a terceira maior taxa de crescimento do valor da produção (92,51\% a.a.) no subperíodo 1980-1985, onde o rendimento foi o principal fator explicativo para esse grande crescimento. $\mathrm{O}$ rendimento 
aumentou à taxa de 60,87\%; não menos importante foi o efeito área (30,38\% a.a.). As culturas produzidas em 1985 nesta microrregião foram o arroz e o milho.

Visualiza-se, na Tabela 27, taxa positiva de crescimento do valor da produção (4,50\% a.a.), destacando-se o aumento de área à taxa de 7,40\% a.a. e a redução de 3,67\% a.a. do rendimento. Entre os anos 1990 e 1995, os efeitos rendimento e área responderam por aproximadamente 95\% do crescimento do valor da produção, que foi de 15,42\% ao ano (Tabela 28).

O valor da produção das culturas aumentou à taxa de $11,50 \%$ a.a. no subperíodo 1995-2000, no qual a produtividade cresceu 7,72\% a.a., e a área 2,99\% a.a.. O efeito composição foi de $0,80 \%$ a.a..

\section{Colíder}

A taxa de crescimento do valor da produção do conjunto de culturas desta microrregião foi de 21,98\% a.a. considerando o período como um todo, sendo que o efeito rendimento respondeu por $82 \%$ desse crescimento. A área cresceu à taxa de 3,37\% a.a. e o efeito composição foi de 0,49\% a.a. (Tabela 25).

Os efeitos rendimento e área explicam a variação no valor da produção no subperíodo 1980-1985, cuja taxa de crescimento foi de 93,56\% a.a.. O efeito rendimento foi de $75,54 \%$ a.a. e o efeito área foi de $41,13 \%$ a.a.. O efeito composição apresentou taxa negativa de 23,11\% a.a. (Tabela 26).

Observa-se, na Tabela 27, a baixa taxa de crescimento do valor da produção (0,12\% a.a.) no subperíodo 1985-1990, destacando-se o efeito área negativo de 5,85\% a.a.. O efeito composição foi de 4,10\% a.a. e o efeito rendimento foi de 1,87\% a.a..

Verificou-se um decréscimo no valor da produção do conjunto de culturas de -2,89\% ao ano no subperíodo 1990-1995, explicado pelos efeitos área e composição negativos. O rendimento apresentou um ligeiro aumento no subperíodo (0,10\% a.a.) (Tabela 28).

Houve uma recuperação do valor da produção no subperíodo 1995-2000 (17,64\% a.a.), sendo o rendimento o principal fator responsável, crescendo 12,41\% a.a.. 
A área cresceu à taxa anual de 2,37\% e o efeito composição foi de 2,86\% a.a. (Tabela 29).

\section{Parecis}

A microrregião de Parecis apresentou taxa de crescimento do valor da produção de 18,80\% a.a., e os três efeitos considerados foram importantes para explicar o fato. A área, rendimento e o efeito composição cresceram à taxa anual de 7,46\%, 6,37\% e 4,98\%, respectivamente (Tabela 25).

Visualiza-se, na Tabela 26, o crescimento do valor da produção $(29,01 \%$ a.a.), sendo o efeito composição de 16,54\% a.a.. A área cresceu 16,63\% a.a., mesmo com a redução de área do algodão e do arroz. O rendimento apresentou decréscimo de $4,16 \%$ а.а..

O valor da produção no subperíodo 1985-1990 aumentou à taxa de 18,52\% a.a., com o efeito área respondendo por aproximadamente $85 \%$ desse crescimento. O rendimento e o efeito composição da produção aumentaram à taxa de 1,67\% a.a. e 1,21\% a.a., respectivamente (Tabela 27).

Observa-se, na Tabela 28, que houve crescimento do valor da produção à taxa de 14,18\% a.a., devido ao aumento da área (9,51\% a.a.) e da produtividade (4,79\% a.a.). O efeito composição apresentou taxa negativa de crescimento de $0,11 \%$ a.a.. $\mathrm{O}$ subperíodo seguinte (1995-2000) apresentou comportamento parecido, a taxa de crescimento do valor da produção foi de 14,10\% a.a., ocasionado pelo aumento da área cultivada $(7,80 \%$ a.a. $)$, pelo aumento do rendimento $(3,24 \%$ a.a.) e pelo efeito composição (3,07\% a.a.) (Tabela 29).

\section{Arinos}

A microrregião de Arinos apresentou taxa de crescimento do valor da produção parecida com a de Parecis (18,88\% a.a.) entre 1980 e 2000, no entanto, seus efeitos área, rendimento e composição foram diferentes, sendo 9,06\% a.a., 6,79\% a.a. e 
3,03\% a.a., respectivamente. Esta microrregião apresentou taxa de crescimento positiva para o valor da produção para todos os subperíodos.

No subperíodo 1980-1985, a taxa de crescimento do valor da produção foi de $38,41 \%$ a.a., sendo a área o principal fator determinante desse crescimento $(48,56 \%$ a.a.). O efeito composição foi 1,12\% a.a. e a produtividade decresceu à taxa de $-11,27 \%$ a.a. (Tabela 26). As áreas das culturas do algodão, arroz, milho e soja expandiram-se consideravelmente no período. A razão para isto decorre do grande aumento da produção proveniente da expansão de área e em menor grau da produtividade. O efeito rendimento é dado pela diferença entre o efeito área e produtividade, em conjunto, e o efeito área.

Todos os efeitos explicativos do crescimento do valor da produção (7,71\% a.a.) foram positivos no subperíodo 1985-90. Os efeitos área, rendimento e composição foram de 2,07\% a.a., 2,26\% a.a. e 3,38\% a.a., respectivamente (Tabela 27). Todos os fatores explicativos do valor da produção no subperíodo 1990-95 também foram positivos, sendo a produtividade o principal responsável pelo crescimento da produção (4,66\% a.a.). O efeito composição foi de 2,53\% a.a. e o efeito área de 2,04\% a.a. (Tabela 28).

Observa-se, na Tabela 29, que a taxa de crescimento do valor da produção no subperíodo 1995-2000 foi de 22,66\% a.a.; a área cresceu à taxa de 13,20\% a.a. e foi o principal fator responsável pelo crescimento da produção. O rendimento se elevou à taxa de $6,36 \%$ a.a. e o efeito composição foi de 3,10\% a.a..

\section{Alto Teles Pires}

A microrregião de Alto Teles Pires, situada no centro do estado e a maior produtora de arroz do Mato Grosso, apresentou taxa de crescimento do valor da produção de 23,95\% a.a., de 1980 a 2000. O crescimento da produtividade (10,61\% a.a.) foi o principal fator explicativo, seguido do efeito área $(10,29 \%$ a.a.) e do efeito composição (3,05\% a.a.) (Tabela 25). 
No subperíodo 1980-1985, o crescimento do valor da produção foi de 31,39\% a.a.; os efeitos área (18,66\% a.a.) e composição (15,49\% a.a.) foram responsáveis pelo crescimento do valor da produção, visto que o rendimento decresceu à taxa de -2,76\% a.a. (Tabela 26). O efeito área respondeu por 85\% do crescimento do valor da produção (30,73\% a.a.) no subperíodo 1985-90; o efeito composição e o rendimento cresceram à taxa de 2,42\% e 2,10\% a.a., respectivamente (Tabela 27). O crescimento da área $(13,63 \%$ a.a.) foi novamente o fator que mais contribuiu para o crescimento do valor da produção (16,45\% a.a.). O efeito rendimento foi de 4,80\% a.a. e o efeito composição de $-1,98 \%$ a.a. (Tabela 28).

No subperíodo 1995-2000, todos os componentes explicativos foram positivos; a área cresceu à taxa de 10,77\% a.a., a produtividade cresceu à taxa de 5,26\% a.a. e a composição da produção à taxa de 1,97\% a.a. (Tabela 29).

\section{Sinop}

O valor da produção de Sinop aumentou à taxa de 39,73\% a.a., impulsionado pelo aumento da produtividade (32,29\% a.a.). A área expandiu-se à taxa de 3,94\% a.a. e o efeito composição foi 3,50\% a.a. (Tabela 25). Esta microrregião foi a que apresentou a maior taxa de crescimento do valor da produção no período considerado.

O maior crescimento do valor da produção observado no subperíodo 19801985 foi também para Sinop (129,38\% a.a.). O rendimento foi o fator explicativo que mais cresceu (94,74\% a.a.), seguido pela área (25,58\% a.a.) e composição da produção (9,06\% а.а.) (Tabela 26).

No subperíodo 1985-1990, a área foi o fator que mais explicou o crescimento do valor da produção, seguido, pelo efeito composição e, por último, pelo efeito rendimento (Tabela 27). O arroz foi a cultura que não apresentou expansão de área no período. Já no subperíodo 1990-1995, o efeito rendimento foi o principal determinante do crescimento do valor da produção (7,88\% a.a.). A área cresceu à taxa de 5,23\% a.a. e o efeito composição foi de -1,10\% a.a. (Tabela 28). 
A área cresceu à taxa de 23,01\% a.a. no subperíodo 1995-2000 e se constitui no principal fator determinante do crescimento do valor da produção (35,16\% a.a.). A produtividade cresceu à taxa de 7,93\% a.a. e o efeito composição foi de 4,22\% a.a. (Tabela 29).

\section{Paranatinga}

Na microrregião de Paranatinga o crescimento da produtividade $(14,31 \%$ a.a.) foi o principal fator determinante do crescimento do valor da produção (18,74\% a.a.) de 1980 a 2000 (Tabela 25). O efeito rendimento foi o principal determinante do aumento do valor da produção no subperíodo 1980-85, alcançando crescimento de 35,14\% a.a.. O crescimento da área foi de 15,14\% a.a. e o efeito composição foi 0,40\% a.a. (Tabela 26).

O crescimento da produção no subperíodo 1985-90 foi bem inferior ao registrado no subperíodo anterior (7,43\% a.a.). O rendimento cresceu à taxa de 5,74\% a.a., sendo este o componente que mais contribuiu para o aumento da produção. O efeito área foi de 1,10\% a.a. e o efeito composição (0,58\% a.a.) (Tabela 27).

Observa-se, na Tabela 28, que o efeito área foi de 8,83\% a.a., respondendo por 99,7\% do crescimento do valor da produção. O efeito composição foi de -1,42\% a.a.. A taxa de crescimento da produtividade foi de 1,45\% a.a. e o valor da produção cresceu à taxa de 8,86\% a.a. (Tabela 28).

Os três fatores explicativos do valor da produção foram positivos no subperíodo 1995-2000. O crescimento da produtividade (7,24\% a.a.) impulsionou em maior grau o crescimento do valor da produção. A área aumentou à taxa de 4,36\% a.a. e o efeito composição foi de 1,22\% a.a. (Tabela 29). 


\section{Norte Araguaia}

A taxa de crescimento do valor da produção dessa microrregião foi de 6,87\% a.a., entre os anos de 1980 e 2000. A área cresceu à taxa de 4,85\% a.a. e o efeito rendimento foi de 2,60\% a.a. (Tabela 25).

No subperíodo 1980-1985, a taxa de crescimento do valor da produção foi de 19,45\% a.a., sendo a área o principal fator responsável por esse aumento (16,13\% а.а.). O aumento da produtividade foi de 3,03\% a.a. e o efeito composição foi de 0,28\% a.a. (Tabela 26). Os efeitos rendimento e composição contribuíram negativamente no crescimento do valor da produção no subperíodo 1985-1990 (Tabela 27).

No subperíodo 1990-1995, houve decréscimo no valor da produção à taxa de -5,41\% a.a., decréscimo verificado também na área (-6,65\% a.a.). Verificou-se redução das áreas alocadas para as culturas selecionadas, não havendo o plantio de soja. A produtividade cresceu à taxa de 0,79\% a.a. (Tabela 28). Visualiza-se, na Tabela 29, a recuperação do crescimento do valor da produção (8,62\% a.a.) e a expansão da área à taxa de 5,41\% a.a. no subperíodo 1995-2000. O rendimento e o efeito composição apresentaram taxa de crescimento de 3,20\% e de 0,02\% a.a., respectivamente.

\section{Canarana}

Esta microrregião apresentou a terceira maior taxa de crescimento do valor da produção entre as microrregiões do estado (26,69\% a.a.); a produtividade foi o principal responsável por esse crescimento, aumentando à taxa de 16,24\% a.a.; o efeito composição foi de 9,11\% a.a., enquanto que o efeito área foi de 1,34\% a.a. (Tabela 25). No subperíodo 1980-1985, a taxa de crescimento do valor da produção foi de 71,62\% a.a.; a produtividade cresceu à taxa de 47,86\% a.a., o efeito composição foi de 17,23\% a.a. e a expansão da área foi de 6,52\% a.a. (Tabela 26).

O crescimento da área $(14,24 \%$ a.a.) foi o principal fator explicativo do crescimento do valor da produção no subperíodo 1985-1990, diferentemente do que ocorreu no subperíodo anterior. Verificou-se diminuição de área apenas para a cultura do 
milho. A produtividade cresceu à taxa de $4,40 \%$ a.a. e o efeito composição foi de 2,34 \% a.a. (Tabela 27).

A taxa de crescimento do valor da produção de Canarana, no subperíodo 1990-1995, foi de 10,94\% a.a., com os efeitos área, rendimento e composição, apresentando taxas anuais médias de 3,67\%, 6,08\% e 1,19\%, respectivamente (Tabela 28). O efeito composição foi o maior no subperíodo 1995-2000 (4,93\% a.a.), superando os efeitos produtividade e área (Tabela 29).

\section{Médio Araguaia}

Esta microrregião foi a que registrou a maior redução do valor da produção (-10,79\% a.a.), destacando-se a redução da área de -11,36\% a.a., (apenas a área alocada com soja se expandiu). A produtividade teve um pequeno crescimento de 0,38\% a.a., e o efeito composição foi positivo, mas pequeno (0,19\% a.a.) (Tabela 25).

A redução do valor da produção do conjunto de culturas no Médio Araguaia foi mais forte no subperíodo 1980-85, (-24,20\% a.a.), com decréscimo na área de 25,77\% a.a., aliado à queda na produtividade de $-0,60 \%$ a.a.. O efeito composição foi de 2,17\% a.a., amenizando a redução da produção (Tabela 26).

Verificou-se crescimento do valor da produção apenas no subperíodo 19851990, determinado principalmente pela produtividade, e, em seguida, pela composição da produção. Mais uma vez a área diminuiu, desta vez à taxa de -2,48\% a.a. (Tabela 27).

Observa-se, na Tabela 28, diminuição do valor da produção (-10,94\% a.a.), ocasionada pela redução da área (-12,00\% a.a.), principalmente do milho, e efeito composição negativo (-0,36\% a.a.). A produtividade aumentou à taxa de 1,42\% a.a.. Verificou-se, no subperíodo posterior (1995-2000), redução do valor da produção da ordem de 6,51\% a.a., devido ao efeito área negativo (-9,16\% a.a.). Por outro lado, o rendimento e o efeito composição da produção cresceram a taxas de 1,51\% a.a. e 1,14\% a.a., respectivamente (Tabela 29). 


\section{Alto Guaporé}

Dentre as microrregiões que apresentaram redução do valor da produção do conjunto de culturas, esta foi a que apresentou a menor queda (-0,38\% a.a.), acompanhada da redução da área (-1,89\% a.a.). As culturas do arroz e do milho foram as que perderam área entre os anos de 1980 e 2000. A produtividade e a composição da produção cresceram à taxa de 1,16\% a.a. e 0,36\% a.a., respectivamente, o que não foi suficiente para causar elevação da produção (Tabela 25).

Houve crescimento do valor da produção de $17,53 \%$ a.a. no subperíodo 1980-1985, decorrente do aumento área (19,89\% a.a.). A produtividade decresceu à taxa de 3,27\% a.a. (Tabela 26). Ao contrário do subperíodo anterior, no subperíodo 19851990, ocorreu redução do valor da produção à taxa de 16,82\% a.a., impulsionado pela redução da área em 17,65\% a.a.. A produtividade cresceu apenas 0,01\% a.a.. Somente o algodão teve aumento na área plantada. O efeito composição da produção foi positivo (0,81\% a.a.) (Tabela 27).

O valor da produção do conjunto de culturas voltou a crescer no subperíodo 1990-95 devido ao aumento da produtividade (4,05\% a.a.) e ao aumento da área (3,15\% a.a.) (Tabela 28). A taxa de crescimento da produção tornou a ser negativa (-5,40\% a.a.) no subperíodo 1995-2000 por causa da retração de área (-8,77\% a.a.) e do efeito composição (-1,13\% a.a.) (Tabela 29). O efeito produtividade foi de 4,51\% a.a. Somente a cultura da soja teve expansão de área nesse subperíodo.

\section{Tangará da Serra}

A taxa de crescimento do valor da produção dessa microrregião foi de 5,95\% a.a., explicado pelos efeitos área, rendimento e composição positivos de 1,30\% a.a., 3,66\% a.a. e 0,98\% a.a., respectivamente (Tabela 25).

A taxa de crescimento do valor da produção no subperíodo 1980-85 foi de 0,10\% a.a., contribuindo para isso o efeito composição de 1,61\% a.a. e o efeito rendimento de 1,01\% a.a.. Houve uma retração da área de 2,72\% a.a. devido à grande 
redução de área do arroz, passando de 25.131 ha em 1980 para 9.987 ha em 1985 (Tabela 26).

No subperíodo 1985-1990, a expansão da área foi o principal fator determinante do aumento do valor da produção (EA = 10,66\% a.a.) (Tabela 27). O efeito área contribuiu negativamente para o crescimento da produção no subperíodo 1990-1995 (-0,78\% а.а.). O principal fator determinante do aumento do valor da produção foi a produtividade, cuja elevação se deu à taxa de 2,45\% a.a. (Tabela 28).

No subperíodo 1995-2000, a microrregião de Tangará da Serra apresentou modesto aumento na área plantada (0,18\% a.a.) e na produtividade das culturas $(4,24 \%$ a.a.), levando ao aumento do valor da produção à taxa média anual de 3,44\% (Tabela 29).

Jauru

A microrregião de Jauru apresentou redução do valor da produção à taxa de 2,28\% a.a. devido à redução da área plantada das culturas (-3,36\% a.a.), enquanto que a produtividade cresceu à taxa de $0,75 \%$ a.a. e o efeito composição foi de 0,33\% a.a. (Tabela 25).

A taxa de crescimento do valor da produção foi de 1,29\% a.a. no subperíodo 1980-85, destacando-se o crescimento da área (2,91\% а.а.), enquanto que os outros efeitos foram negativos (Tabela 26). A importância dos fatores determinantes do valor da produção para o subperíodo 1985-90 inverteu-se, pois o efeito área apresentou-se negativo $(0,62 \%$ a.a.) e os efeitos rendimento e composição foram positivos: de $1,26 \%$ a.a. e 5,03\% a.a., respectivamente (Tabela 27). O aumento do valor da produção foi verificado a uma taxa média de 5,66\% a.a.. As áreas de arroz, milho e soja sofreram reduções.

Visualiza-se, na Tabela 28, que o efeito composição foi o principal fator determinante do aumento da produção (2,17\% a.a.), o efeito área foi negativo (-2,23\% a.a.), enquanto que a produtividade pouco cresceu no subperíodo (0,33\% a.a.). 
A taxa negativa de crescimento da produção foi de $15,02 \%$ a.a. no subperíodo 1995-2000, fazendo com que a taxa em todo o período fosse negativa. Contribuiu para a redução do valor da produção a área (-14,49\% a.a.) e o efeito composição (-5,06\% a.a.); a produtividade cresceu à taxa de 4,53\% a.a. (Tabela 29).

\section{Alto Paraguai}

Entre 1980 e 2000, a microrregião de Alto Paraguai apresentou taxa de crescimento do valor da produção de 7,23\% a.a., dada pelo aumento da produtividade (5,15\% a.a.) e pelo aumento da área (2,13\% a.a.); o efeito composição teve participação negativa no valor da produção, apesar de pequeno (-0,05\% a.a.) (Tabela 25).

No primeiro subperíodo (1980-1985), a taxa de crescimento do valor da produção foi negativa (-0,52\% a.a.) devido aos efeitos área e rendimento de $-3,33 \%$ a.a. e $-1,22 \%$ a.a., respectivamente. O efeito composição positivo amenizou a queda no valor da produção (4,03\% a.a.). (Tabela 26).

A produção recuperou-se no subperíodo 1985-1990, apresentando taxa positiva de crescimento (5,39\% a.a.); o efeito composição foi o que mais explicou essa alta (2,89\% a.a.). A área e o rendimento cresceram 1,78\% a.a. e 0,72\% a.a., respectivamente.

Entre os anos de 1990 e 1995, todos os fatores determinantes do crescimento do valor da produção foram positivos, a exemplo do subperíodo anterior; a expansão da área foi de 4,50\% a.a., a produtividade elevou-se em 3,68\% a.a. e o efeito composição foi de 1,42\% a.a. (Tabela 28). A taxa de crescimento da produção entre os anos de 1995 e 2000 foi de 15,04\% a.a., contribuindo para este desempenho o aumento da área e da produtividade de 9,21\% a.a. e 6,61\% a.a., respectivamente (Tabela 29).

\section{Rosário Oeste}

No período de 1980 a 2000, a microrregião de Rosário Oeste apresentou decréscimo do valor da produção de 4,19\% a.a., explicado pela redução da área das 
culturas (-5,10\% a.a.), exceto da soja. O rendimento e o efeito composição tiveram leve aumento de $0,51 \%$ a.a. e 0,40\% a.a., respectivamente (Tabela 25).

A taxa de crescimento da produção foi de 10,55\% a.a. no subperíodo 19801985, explicada pelo aumento da área (5,99\% a.a.), efeito composição positivo (3,54\% a.a.) e pela elevação da produtividade (1,02\% a.a.) (Tabela 26).

A produção apresentou taxa negativa de crescimento (-5,68\% a.a.) entre os anos de 1985-1990, ocasionada pela retração da área cultivada na microrregião (-8,30\% a.a.) devido, principalmente, ao recuo da área plantada com arroz. Os efeitos decorrentes da mudança da produtividade e da composição da produção foram de 1,36\% a.a. e 1,26\% a.a., respectivamente (Tabela 27).

A redução mais forte do valor da produção ocorreu no subperíodo 19901995, (-19,06\% а.а.), sendo responsáveis por isso os efeitos área, rendimento e composição, que reduziram à taxa de 16,71\% a.a., 1,98\% a.a. e 0,38\% a.a., respectivamente, conforme pode ser visto na Tabela 28.

A produção decresceu à taxa de 0,15\% a.a. no subperíodo 1995-2000, devido ao efeito área (-3,77\% a.a.). A mudança na composição da produção (3,06\% a.a.) amenizou a redução do valor da produção. O efeito rendimento cresceu muito pouco no subperíodo, apenas $0,55 \%$ a.a..

\section{Cuiabá}

No período de 1980 a 2000, a microrregião de Cuiabá apresentou decréscimo do valor da produção à taxa de 6,14\% a.a., explicado em maior parte pela redução da área (-7,23\% a.a.). O rendimento e o efeito composição amenizaram a queda da produção, crescendo à taxa de 0,49\% a.a. e 0,60\% a.a., respectivamente (Tabela 25).

O valor da produção cresceu à taxa anual média de 5,99\% a.a. no subperíodo 1980-85, explicado principalmente por mudanças na composição da produção, com o cultivo da soja sendo intensificado por possibilitar maior rentabilidade. O efeito composição respondeu por aproximadamente 96\% do crescimento do valor da produção. 
O efeito área foi de $-0,46 \%$ a.a. e a produtividade cresceu à taxa de 0,72\% a.a. (Tabela 26).

O maior decréscimo do valor da produção foi verificado no subperíodo 1985-90, (-28,45\% a.a.) devido à redução da área (-27,65\% a.a.). Todas as culturas sofreram diminuição na área cultivada, exceto o algodão que teve um leve aumento. A produtividade das culturas aumentou à taxa de 0,17\% a.a. e o efeito composição da produção foi negativo e pequeno (-0,97\% a.a.) (Tabela 27). As condições verificadas no subperíodo 1990-1995 foram bastante parecidas com as do subperíodo anterior e com as observadas em Colíder e Médio Araguaia para o mesmo intervalo de tempo. Verificouse redução da taxa de crescimento da produção (-3,51\% a.a.) e redução da área e do efeito composição de $-4,87 \%$ a.a. e $-1,28 \%$ a.a., respectivamente. A produtividade aumentou à taxa de 2,65\% a.a. (Tabela 28).

O valor da produção voltou a crescer no último subperíodo, desta vez à taxa de 6,06\% a.a. devido ao efeito composição (4,11\% a.a.), seguido pelo efeito rendimento (2,38\% a.a.). A área diminuiu à taxa de -0,43\% a.a., principalmente pela redução da área do arroz e do milho (Tabela 29).

\section{Alto Pantanal}

Esta microrregião foi a que apresentou o segundo maior decréscimo do valor da produção (-6,63\% a.a.) entre 1980 e 2000, devendo-se o fato a forte diminuição da área das culturas (-7,16\% a.a.), especialmente do arroz. O efeito composição manteve-se praticamente estável (-0,07\% a.a.); houve um leve crescimento da produtividade de 0,59\% a.a. (Tabela 25).

No subperíodo 1980-1985, a taxa de crescimento do valor da produção da microrregião de Alto Pantanal foi de 2,67\% a.a., o efeito área foi de 5,72\% a.a. e o efeito composição foi 0,73\% a.a., porém, a produtividade contribuiu negativamente na taxa de crescimento do valor da produção (-3,78\% a.a.) (Tabela 26). Verificou-se redução da produção de $-12,90 \%$ a.a. no subperíodo 1985-1990, explicada principalmente pela retração da área (-14,73\% a.a.), especialmente de arroz, milho e soja. A produtividade 
reduziu-se à taxa de $-0,31 \%$ a.a. e o efeito composição foi positivo (2,14\% a.a.) (Tabela 27).

De 1990 a 1995, a taxa anual média de crescimento da produção foi de 3,09\% a.a., destacando-se o efeito área negativo e elevado (-6,71\% a.a.). O rendimento e o efeito composição suavizaram a redução do valor da produção, com crescimento de 1,48\% a.a. e 2,14\% a.a., respectivamente (Tabela 28).

Registrou-se, entre os anos de 1995 e 2000, a segunda maior redução da taxa de crescimento do valor da produção na microrregião de Alto Pantanal (-12,31\% a.a.), explicada pela diminuição da área plantada (-12,62\% a.a.) e pelo efeito composição negativo (-4,45\% a.a.). O efeito rendimento, diferentemente do subperíodo 1980-85 e 1985-90, foi o fator que impediu a maior queda da produção - seu crescimento foi de 4,76\% a.a. (Tabela 29).

\section{Primavera do Leste}

Não foi possível analisar a evolução do valor da produção das culturas do algodão, arroz, milho e soja para os períodos de 1980-2000, 1980-85 e 1985-90 devido a inexistência de dados referentes à década de 80 .

O valor da produção da microrregião de Primavera do Leste cresceu à taxa de 7,52\% a.a. no subperíodo 1990-95. O efeito área foi o principal fator determinante desse crescimento. A área aumentou 5,62\% a.a., a produtividade aumentou 2,29\% a.a., o efeito composição foi $-0,40 \%$ a.a. (Tabela 28). A cultura do arroz foi a única a perder área no subperíodo.

Entre os anos de 1995-2000, o crescimento da produção foi de 12,58\% a.a., sendo o efeito composição o principal fator determinante desse crescimento (6,90\% a.a.). A produtividade cresceu à taxa de 3,29\% a.a. e a área cresceu à taxa de 2,38\% a.a. (Tabela 29). Verificou-se um grande crescimento da área da cultura do algodão nesse subperíodo, aumento de 5.418\%, passando de 1.011 ha em 1995 para 55.787 ha em 2000. 
Tesouro

A microrregião de Tesouro apresentou taxa de crescimento do valor da produção de 9,51\% a.a., explicado principalmente pelo efeito composição da produção (4,58\% a.a.). A produtividade cresceu à taxa de 2,63\% a.a. e a área aumentou 2,30\% a.a. (Tabela 25). A cultura do arroz perdeu aproximadamente $60 \mathrm{mil}$ ha entre os anos de 1980 e 2000.

Verifica-se que no subperíodo 1980-1985, a taxa de crescimento do valor da produção foi de 19,45\% a.a.; o efeito composição foi o principal fator explicativo (12,14\% a.a.). Percebe-se uma grande evolução do plantio de soja no período, motivando a mudança da composição da produção no sentido de introduzir culturas mais rentáveis. O efeito área foi de 7,36\% a.a., com crescimento da área de algodão e soja. Já o rendimento permaneceu praticamente inalterado, contribuindo negativamente para o aumento da produção (-0,05\% a.a.) (Tabela 26).

O valor da produção diminuiu 3,81\% a.a. no subperíodo 1985-90, devido ao efeito área negativo (-6,47\% a.a.), com redução de área de arroz e soja. Os efeitos rendimento e composição foram de 1,53\% a.a. e 1,13\% a.a. (Tabela 27). Ao contrário do subperíodo anterior, desta vez verificou-se aumento no valor da produção de 12,39\% a.a.. Essa variação é explicada pelos efeitos área, rendimento e composição de 9,17\% a.a., 3,06\% a.a. e 0,16\% a.a., respectivamente (Tabela 28).

O aumento do valor da produção também foi verificado entre 1995 e 2000, com uma taxa média de 11,38\% a.a.. O efeito área foi o principal fator determinante desse crescimento (4,93\% a.a.), sendo que apenas o arroz teve retração na área plantada. A produtividade das culturas aumentou à taxa de 4,17\% a.a. e o efeito composição foi 2,28\% a.a. (Tabela 29).

\section{Rondonópolis}

A taxa de crescimento do valor da produção em Rondonópolis foi de 9,59\% a.a., com os efeitos área, rendimento e composição contribuindo para essa elevação. O 
efeito composição foi de 5,06\% a.a., a produtividade cresceu à taxa de 2,80\% a.a. e o efeito área foi de 1,73\% a.a.. Verifica-se grande expansão de área de algodão, milho e soja, em contrapartida de uma forte redução da área de arroz entre os anos de 1980 e 2000.

No subperíodo de 1980-1985, a microrregião apresentou aumento da área plantada com as culturas de interesse (4,98\% a.a.), a taxa de crescimento da produtividade foi de 2,85\% a.a. e o efeito composição foi 9,63\% a.a., levando ao aumento da produção à taxa média de 17,46\% a.a. (Tabela 26).

No subperíodo 1985-1990, a taxa anual média de crescimento do valor da produção foi positiva, de 4,75\% a.a., e todos os fatores explicativos (área, rendimento e composição) foram positivos (Tabela 27). Verificou-se aumento da produção de 6,75\% a.a. no subperíodo 1990-95, explicado pelo efeito área positivo (4,83\% a.a.) e pelo aumento da produtividade (2,03\% a.a.). Todas as culturas tiveram expansão de área neste subperíodo.

Os três fatores determinantes do valor da produção também foram positivos no subperíodo 1995-2000, contribuindo para a elevação do valor da produção à taxa de 9,82\% a.a.. O efeito composição foi de 5,95\% a.a., o aumento da produtividade foi de 3,33\% a.a. e a expansão da área foi de 0,54\% a.a., com redução do plantio de milho e arroz.

\section{Alto Araguaia}

A taxa anual média de crescimento do valor da produção na microrregião de Alto Araguaia foi de 12,55\% a.a., explicada pelos efeitos rendimento, área e composição de 4,97\% a.a., 4,06\% a.a. e 3,52\% a.a., respectivamente. Apenas a cultura do arroz teve redução de área no período de 1980-2000. Verifica-se crescimento do valor da produção em todos os subperíodos analisados. Os efeitos área e rendimento explicam a maior parte do crescimento do valor da produção. 
Verifica-se o maior aumento do valor da produção no subperíodo 1980-85, cujo crescimento foi de $28,97 \%$ a.a., explicado principalmente pelo efeito área (15,06\% a.a.) e efeito composição (10,96\% а.а.) (Tabela 26).

Entre os anos de 1985 e 1990, o aumento da produção ocorreu à taxa de 6,12\% a.a., dado pelo aumento da produtividade (3,40\% a.a.), pelo efeito área (1,97\% a.a.) e pelo efeito composição (0,75\% a.a.) (Tabela 27$)$.

No subperíodo 1990-1995, os efeitos área e rendimento de 3,75\% a.a. e 0,59\% a.a., respectivamente, levaram ao aumento do valor da produção de 4,32\% a.a.. O efeito composição foi negativo mas bastante pequeno (-0,02\% a.a.). No subperíodo 1995-2000, o valor da produção do conjunto das culturas de interesse aumentou à taxa de 12,39\% a.a., explicado pelo aumento da área de 4,95\% a.a.; apenas a área cultivada com milho sofreu redução. A produtividade aumentou à taxa de 3,99\% a.a. e o efeito composição foi de 3,44\% a.a. (Tabela 29).

\subsection{Análise do conjunto de culturas no Estado do Mato Grosso}

A análise das variações ocorridas no valor da produção do conjunto de culturas de interesse do Estado do Mato Grosso é feita considerando os seguintes fatores explicativos: área, rendimento, composição da produção e localização geográfica. De 1980 a 2000, o Mato Grosso apresentou taxa positiva de crescimento do valor da produção, 13,14\% a.a., que pode ser atribuída a todos os fatores mencionados. A mudança na composição da produção foi o principal fator explicativo, com 4,56\% a.a., a área foi expandida à taxa de 4,04\% a.a.. Verifica-se, na Tabela 15, a redução da área de arroz em 208.003 ha.

O maior crescimento do valor da produção de todo o período considerado foi observado em 1980-85, cuja elevação foi à taxa de 17,60\% a.a., impulsionada pelo efeito área (7,36\% a.a.) e pelo efeito composição (6,55\% a.a.). Os efeitos rendimento e localização geográfica foram de 1,98\% a.a. e 1,71\% a.a., respectivamente (Tabela 26). 
Verifica-se, na Tabela 16, que o arroz foi a única cultura a ceder área no subperíodo (317.142 ha).

No subperíodo 1985-1990, o estado apresentou taxa de crescimento do valor da produção de 11,24\% a.a., sendo explicada pelo aumento da área à taxa de 7,46\% e pelo efeito composição (4,98\% a.a.). O crescimento da produtividade foi exíguo (0,43\% a.a.) e o efeito localização geográfica foi de -1,64\% a.a. (Tabela 27).

Entre os anos de 1990-1995, todas as culturas tiveram crescimento do valor da produção, assim como da área plantada. A taxa de crescimento do valor da produção do conjunto das culturas foi de 10,00\% a.a., explicada pelo efeito área (6,25\% a.a.) e pelo efeito rendimento (3,30\% a.a.). O efeito composição foi negativo (-0,27\% a.a.) e o efeito localização foi de 0,72\% a.a. (Tabela 28).

No último subperíodo 1995-2000, a taxa anual de crescimento do valor da produção foi de 13,88\% a.a.. Das fontes de crescimento, a área foi a que teve o maior peso, crescendo à taxa de 6,07\% a.a., seguida pela produtividade (4,28\% a.a.) e pelo efeito composição (3,52\% a.a.). A variação no valor da produção devido ao efeito localização foi praticamente inexistente (0,01\% a.a.) (Tabela 29$)$. 


\section{CONCLUSÕES}

Conclui-se, com base nos resultados apresentados, que a cultura do arroz tem seu uso voltado para a abertura de novas áreas agrícolas, atuando como atividade pioneira na expansão da fronteira agrícola. Observou-se que a orizicultura é também usada na recuperação das pastagens degradadas. A utilização do arroz em rotação de culturas ainda é bem incipiente, e não há uniformidade quanto ao sistema de rotação adotado.

A maioria dos produtores entrevistados planta arroz esporadicamente. A orizicultura no Mato Grosso ainda atravessa alguns problemas tecnológicos, como a oferta insuficiente de sementes e a mistura varietal, no caso da variedade Primavera.

As principais variedades de arroz de terras altas cultivadas no território mato-grossense são a Primavera, Cirad 141 e Maravilha, destacando-se a Primavera por ser bem aceita no mercado e a Cirad 141 pelas boas características agronômicas. O crescimento da produção de arroz de terras altas no estado foi devido principalmente a maior produtividade das variedades empregadas na região, que possibilitaram a redução da diferença quantitativa e qualitativa em relação ao arroz irrigado.

Verificou-se, de forma geral, que quando a orizicultura cede área, ela o faz principalmente para a sojicultura. Com base nos resultados obtidos por regressão econométrica, verificou-se aumento na produção e decréscimo na área de arroz entre os anos de 1980 e 2001 para o estado como um todo; já as culturas do algodão, do milho e da soja tiveram crescimento de produção e na área. Esse comportamento de decréscimo de área para o arroz não foi observado nas regiões norte, centro e oeste mato-grossense. Na região central do estado, assim como na região oeste, houve crescimento da produção e da área das culturas de interesse, inclusive do arroz. Dentre as regiões estudadas, a 
central é a mais importante na produção, no beneficiamento, na comercialização e na distribuição de arroz no estado. Notou-se nos últimos cinco anos o crescimento da produção das culturas de interesse na região leste, sobretudo do algodão. A área cultivada com arroz nessa região foi a única a sofrer redução.

Entre os entraves ao desenvolvimento da orizicultura foram citados nas entrevistas a falta de estrutura de secagem e armazenagem dos produtores matogrossenses, conferindo maiores dificuldades para os mesmos no momento da comercialização.

O arroz produzido no Mato Grosso é comercializado para diversas localidades, como Goiás, São Paulo, Minas Gerais, estados do Nordeste, Rondônia, Acre, Amazonas, Pará, Roraima e também é vendido para a Bolívia, além da própria comercialização dentro do estado.

Os resultados da metodologia "shift-share” para a divisão do efeito área em escala e substituição, para o período de 1980 a 2000, mostraram que o arroz foi a cultura, dentre as estudadas, que cedeu área agrícola, especialmente para a soja, como já comentado. Verifica-se que nesse período o efeito substituição foi, em módulo, superior ao efeito escala, resultando em diminuição da área cultivada com arroz no estado. Detalhando o comportamento de área do arroz, conclui-se que esta cedeu área para as outras culturas nos dois primeiros subperíodos (1980-1985 e 1985-1990) e nos dois últimos subperíodos (1990-1995 e 1995-2000) todas as culturas tiveram expansão da área cultivada. Dentre as culturas analisadas, a orizicultura foi a única a ceder área agrícola.

Com base nos resultados obtidos da análise individual da cultura do arroz, percebeu-se que o crescimento da produção entre os anos de 1980 e 2000 foi devido ao aumento da produtividade e ao efeito localização, que indica que a produção está crescendo em maior proporção em microrregiões mais propícias ao cultivo do cereal. O efeito área contribuiu negativamente na expansão da produção. Verificaram-se taxas negativas de crescimento da produção na década de 1980, causada exclusivamente pela diminuição da área. Isso contraria a hipótese de que a produção de arroz cresceu na década de 1980 devido à expansão da fronteira agrícola. A taxa de crescimento positiva 
da produção de arroz na década de 1990 foi devida principalmente à elevação da produtividade, seguido pelo efeito área. A hipótese do crescimento da produção de arroz na década de 1990 com base na produtividade foi confirmada. O aumento da produtividade impulsionou a produção nessa década, sendo um reflexo do investimento em pesquisa agronômica que se iniciou em meados da década de 1970 e possibilitou a ocupação do cerrado do Centro-Oeste.

Apenas em seis microrregiões observou-se decréscimo na taxa de crescimento do valor da produção entre 1980 e 2000, devendo-se esse fato exclusivamente à diminuição da área. Verifica-se que normalmente a cultura do arroz sofreu redução de área em alguns subperíodos analisados para as diversas microrregiões.

O subperíodo 1980-1985 foi marcado como o de maior crescimento do valor da produção, tanto na análise do estado como um todo, como na análise das microrregiões, possivelmente influenciado por boas condições climáticas e pela facilidade de obtenção do crédito no início da década de 1980, destacando-se os efeitos área e composição.

Os principais fatores explicativos para o crescimento do valor da produção no estado foram o efeito composição e a expansão da área na década de 80 e a expansão da área e o aumento de produtividade na década de 90. 
ANEXOS 
ANEXO A - Modelo de questionário ao produtor.
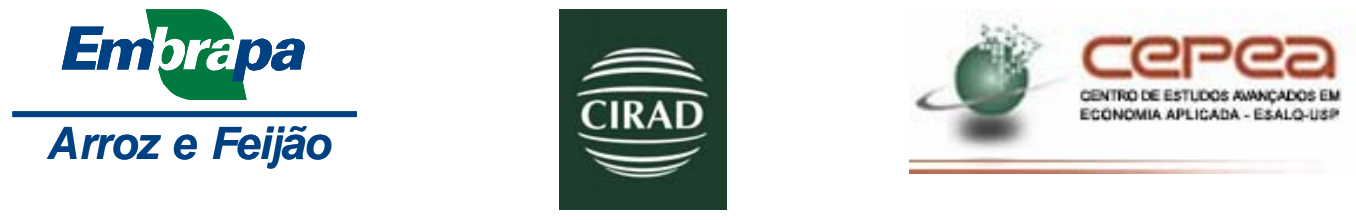

\section{QUESTIONÁRIO PRODUTOR}

Nome do produtor :

Idade: __ anos;

Município/Estado:

Endereço para correspondência

Cidade:

; Estado:

Rua: $\mathrm{N}^{\circ}$

Complemento

Cep: ; e-mail:

Data:

Questionário aplicado por:

\section{1 - DADOS DA PROPRIEDADE}

1.1 - Área total da propriedade ha

1.2 - Posse da Terra: ( 1) Proprietário; 2) Arrendatário; 3) Parceiro; 4) Meeiro; 5) Outros.

Se arrendatário ou Meeiro, qual o valor pago ao proprietário/safra?

1) sc/arroz _ _ ;2) sc/soja __ ; 3) Outros ___ (especificar)

\section{2 - SISTEMA DA PROPRIEDADE}

2.1 - Que culturas são exploradas na propriedade?

Safra atual (2001-02) :

\begin{tabular}{lllllll}
\hline a) Cultura: $\quad$ : & ha; & $\mathrm{kg} . / \mathrm{ha}$ & a) Cultura: & $:$ & $\mathrm{ha} ;$ & $\mathrm{kg} . / \mathrm{ha}$
\end{tabular}

$\begin{array}{lllllll}\text { b) Cultura: } \quad \text { : } & \text { ha; } & \mathrm{kg} . / \mathrm{ha} & \text { b) Cultura: } & : & \mathrm{ha} & \mathrm{kg} . / \mathrm{ha}\end{array}$

\begin{tabular}{lll|llll} 
c) Cultura: $\quad$ : & ha; & $\mathrm{kg} . / \mathrm{ha}$ & c) Cultura: & : & $\mathrm{ha} ;$ & $\mathrm{kg} . / \mathrm{ha}$
\end{tabular}

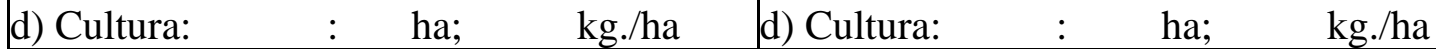

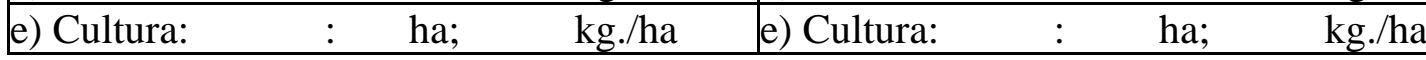

2.2 - Participação, média, dessas culturas na renda total da propriedade?

a) Cultura: $\quad \%$; b) Cultura $\quad \%$; c) Cultura: $\%$; d) Cultura: $\%$;

e) Cultura: $\%$ 


\begin{tabular}{|c|c|c|c|c|c|c|}
\hline \multicolumn{7}{|c|}{$\begin{array}{l}2.3 \text { - Área ocupada com pastagem } \ldots \text { ha. } \\
\text { Áreas Matas e florestas: }\end{array}$} \\
\hline & $=$ & & ( ) não & & & \\
\hline \multicolumn{7}{|c|}{$\begin{array}{l}\text { 2.5 - Em caso positivo quais os esquemas de cultivo predominante na sua propriedade } \\
\text { (ex. pasto-arroz-soja) }\end{array}$} \\
\hline a) & - & - & número de anos de cultivo & 7 & 7 & \\
\hline b) & - & - & número de anos de cultivo & 1 & 7 & \\
\hline c) & - & - & número de anos de cultivo & 7 & 7 & \\
\hline d) & - & - & número de anos de cultivo & 1 & 1 & \\
\hline
\end{tabular}

2.6 - Você cultiva em plantio direto? ( ) Sim; ( ) Não;

Área total em plantio direto ___ ha

Área de arroz em plantio direto:__ ha; Outras áreas: ha (especificar culturas):

2.7 - Teve algum tipo de problema com esse sistema? Qual?

2.8 - Detalhamento do esquema e rotação

\begin{tabular}{l}
$\begin{array}{l}\text { Área plantada } \\
\text { com ARROZ } \\
\text { na safra } \\
2001 / 2002 ; \\
\text { ha }\end{array}$ \\
\hline Área plantada com PASTO na safra 2000/2001; __ ha ha
\end{tabular}




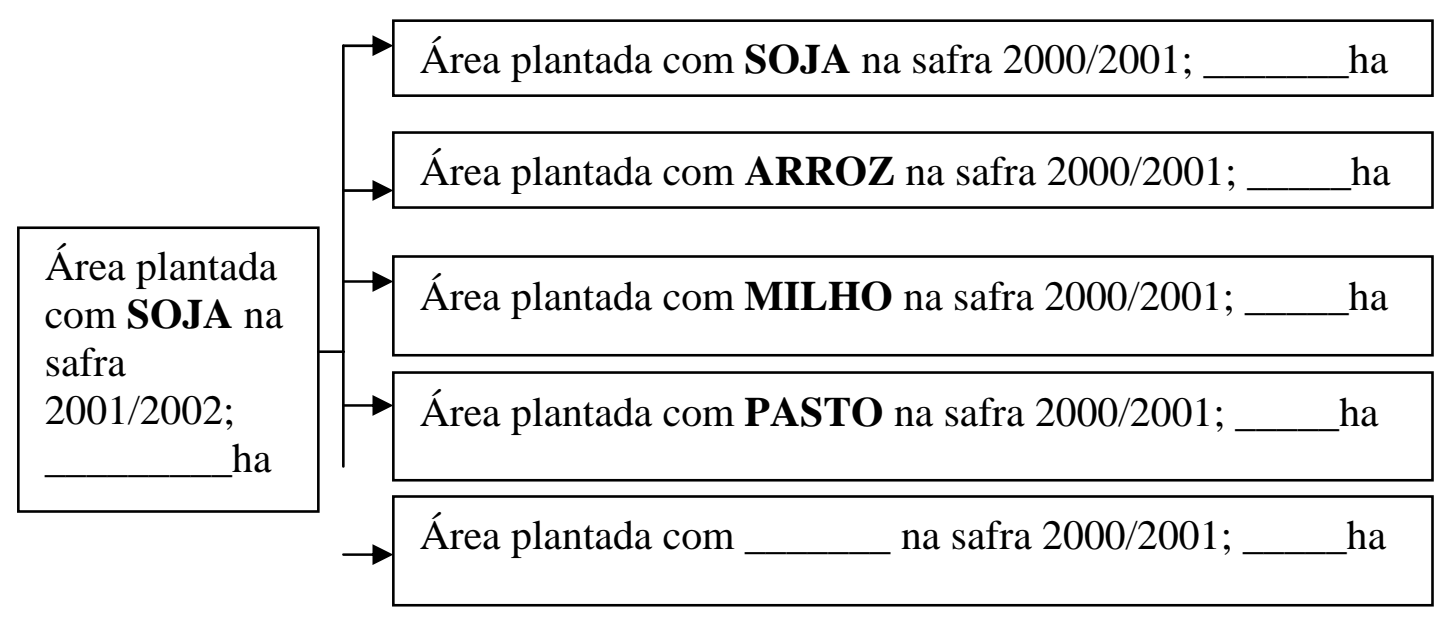

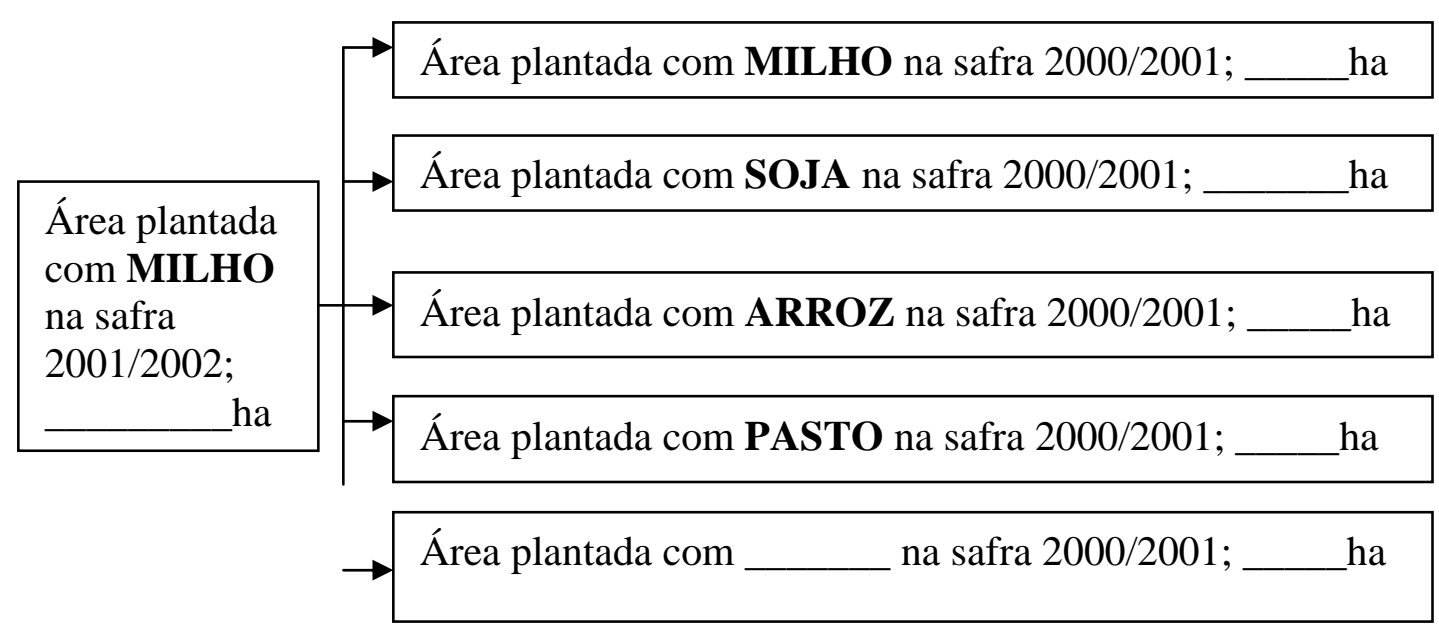

$\left.\begin{array}{l}\text { Área plantada } \\ \text { com } \begin{array}{l}\text { na safra } \\ 2001 / 2002 ;\end{array}\end{array}\right)$ Área plantada com SOJA na safra 2000/2001;




\section{3 - DADOS SOBRE A CULTURA DO ARROZ}

3.1 - Você se definiria como:

( ) produtor esporádico de arroz; ( ) produtor de arroz "profissional"

( ) produtor de arroz por falta de opção (a cultura se adapta às necessidades da propriedade)

3.2 - Citar, em ordem de importância, os três principais motivos que o levam a cultivar arroz :

a)

b)

c)

3.3 - A percepção dominante é que o cultivo do arroz está fundamentalmente relacionado com a abertura de áreas novas, sejam elas áreas recém desmatadas ou áreas sem cultivos por alguns anos. Na sua opinião, considerando os últimos três anos, esse continua sendo o principal papel da cultura na sua região ou ela tem um novo papel? Qual e porque?

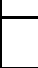

3.4 - Participação média do arroz na renda total da propriedade é:

$\%$

3.5 - Qual o peso de importância dos fatores na definição do tamanho da área cultivada com arroz. Coloque o número 1 na frente daquela qualidade que vocês acham mais importante, número 2 para aquela que vocês consideram a segunda mais importante, e assim sucessivamente até chegar no número 6.

\begin{tabular}{|c|c|c|}
\hline Disponibilidade de semente & ( & \\
\hline Preço do arroz no ano anterior & ( & ) \\
\hline Perspectiva de preços no ano da colheita & ( & ) \\
\hline Necessidade de rotação de cultura na propriedade & ( & ) \\
\hline Preço dos insumos utilizados no cultivo da soja & ( & ) \\
\hline Outros (especificar) & ( & ) \\
\hline
\end{tabular}

3.6 - Em que época você toma decisão se cultiva ou não o arroz e tamanho da área. Logo após a colheita ( $\quad$ ); Três meses antes do plantio ( $\quad$ ); Dois meses antes do plantio ( ); Um mês antes do plantio ( ) 
3.7 - Qual o peso de importância dos fatores na definição da utilização de uma variedade de arroz. Coloque o número 1 na frente daquela qualidade que vocês acham mais importante para decidir qual marca vocês comprariam, número 2 para aquela qualidade que vocês consideram a segunda mais importante, e assim sucessivamente até chegar no número 10.

Variedade nova

Disponibilidade de semente

Produtividade

Arquitetura da planta

Resistência a degrana

Rusticidade

Preço pago pela indústria (envolve qualidade industrial e culinária)

Tolerância a pragas e doenças

Maturação pós colheita

Outros (especifica) :

3.8 - Principal meio que toma conhecimento de variedades:

Acompanhando lavouras de vizinhos ( ); Dia de campo ( );

Programas televisivos ( ); Programas de rádio ( ); Outros (especificar)

$($ )

\begin{tabular}{|c|c|c|}
\hline \multicolumn{3}{|c|}{3.9 - Usa semente certificada. (Ordenar ..) } \\
\hline \multirow{3}{*}{ SIM } & Maior produtividade & ( \\
\hline & Oferece maior segurança contra doenças & ( \\
\hline & Resulta em produto de melhor qualidade & \\
\hline
\end{tabular}

\begin{tabular}{|l|l|r|}
\hline \multirow{5}{*}{ NÃOO } & Não aumenta a produtividade & $(\quad)$ \\
\cline { 2 - 3 } & Não oferece segurança contra doenças & $(\quad)$ \\
\cline { 2 - 3 } & $\begin{array}{l}\text { Não interfere ou interfere pouco na qualidade do produto } \\
\text { final }\end{array}$ & $(\quad)$ \\
\cline { 2 - 3 } & Benefícios não são compatíveis com o seu custo & $(\quad)$ \\
\hline & Dificuldades em encontrar no mercado & $(\quad)$ \\
\hline
\end{tabular}

3.10- Variedades utilizadas nesses três últimos anos e participação delas em relação à área cultivada com arroz na sua propriedade.

\begin{tabular}{|l|c|c|c|}
\hline \multirow{2}{*}{ Variedades } & \multicolumn{3}{|c|}{ Participação \% nas safras } \\
\cline { 2 - 4 } & $1999 / 2000$ & $2000 / 2001$ & $2001 / 2002$ \\
\hline & & & \\
\hline & & & \\
\hline & & & \\
\hline
\end{tabular}


3.10.1 - Qual foi a melhor? Por que?

3.10.2 - Qual foi a pior? Por que?

3.11 - Em ordem de importância quais são os principias problemas que afetam a qualidade do arroz:

a)

b)

c)

d)

3.12 - Em relação ao arroz você percebeu alguma mudança nos últimos 3 anos em relação a:

Variedades:

Outras tecnologias:

Mercado:

\section{4 - COMERCIALIZAÇÃO E FLUXO}

\section{1 - Quais são os principais compradores de seu arroz?}

\% outros produtores; _ _ \% atacadistas do estado;

$\%$ atacadistas de outros estados (citar os três principais) ___ _ _ _ _ _ \% indústria do estado; \% indústria de outros estados (citar os três principais)

4.2 - Que percentual de arroz você comercializa?

\% um mês após colheita; ___ dois meses após colheita; ___ \% seis meses após colheita 
4.3 - Quais características os compradores valorizam no arroz?

a)

b)

c)

4.4 - Preço médio por saco de venda de arroz na safra anterior

\begin{tabular}{|l|l|}
\hline \multicolumn{1}{|c|}{ Variedade } & Preço médio R\$/saco \\
\hline a) & \\
\hline b) & \\
\hline d) & \\
\hline e) & \\
\hline
\end{tabular}

4.5 - A comercialização do arroz é semelhante a da soja, milho? ( ） sim （ ） não Caso respondeu não, quais são as principais diferenças?

a)

b)

c) 
ANEXO B - Modelo de questionário aplicado as agroindústrias.
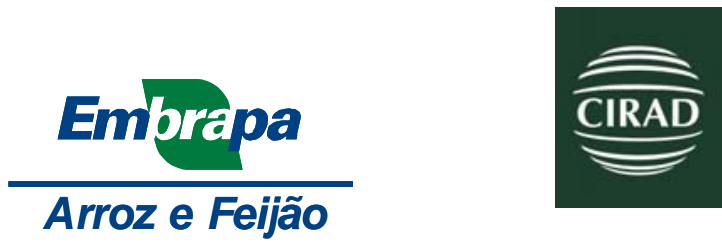

\section{QUESTIONÁRIO AGROINDÚSTRIA}

1 - Nome da indústria:

2 - Nome do responsável:

3 - Município: ; 4 - Estado:

Endereço para correspondência

5 - Telefone: ( )

6 - Cidade: ; 7 - Estado:

8 - Rua: ; $9-\mathrm{N}^{\circ}$

10 - Complemento

11 - Cep:

12 - e-mail:

13 - Data:

14 - Questionário aplicado por:

\section{1 - PRODUTOS COMERCIALIZADOS}

\begin{tabular}{|l|l|l|l|l|}
\hline Marca & Tipo & Classe & $\%$ & Destino* \\
\hline & & & & \\
\hline & & & & \\
\hline & & & & \\
\hline & & & & \\
\hline & & & & \\
\hline
\end{tabular}

Classe: $\mathrm{L}=$ longo, $\mathrm{M}=$ Médio, $\mathrm{C}$ = curto; Tipo, 1, 2, 3, 4, 5 ; Unidades de compra: $\mathrm{F}=$ feiras livres; PA = pequenos armazéns; $\mathrm{S}=$ supermercados; $\mathrm{RS}=$ grandes redes de supermercado 


\section{2 - MATÉRIA-PRIMA}

\begin{tabular}{l} 
Origem, \% quantidade e qualidade são satisfatórias, problemas na aquisição, \\
variedades, vantagens desvantagens, formas de aquisição, classificação, teste de \\
cocção, definição do preço pago. \\
\hline
\end{tabular}

\section{3 - DEFINIÇÃO DA QUALIDADE}

Quais atributos na definição da qualidade da matéria-prima? Coloque de 1 a 11, segundo o grau de importância.

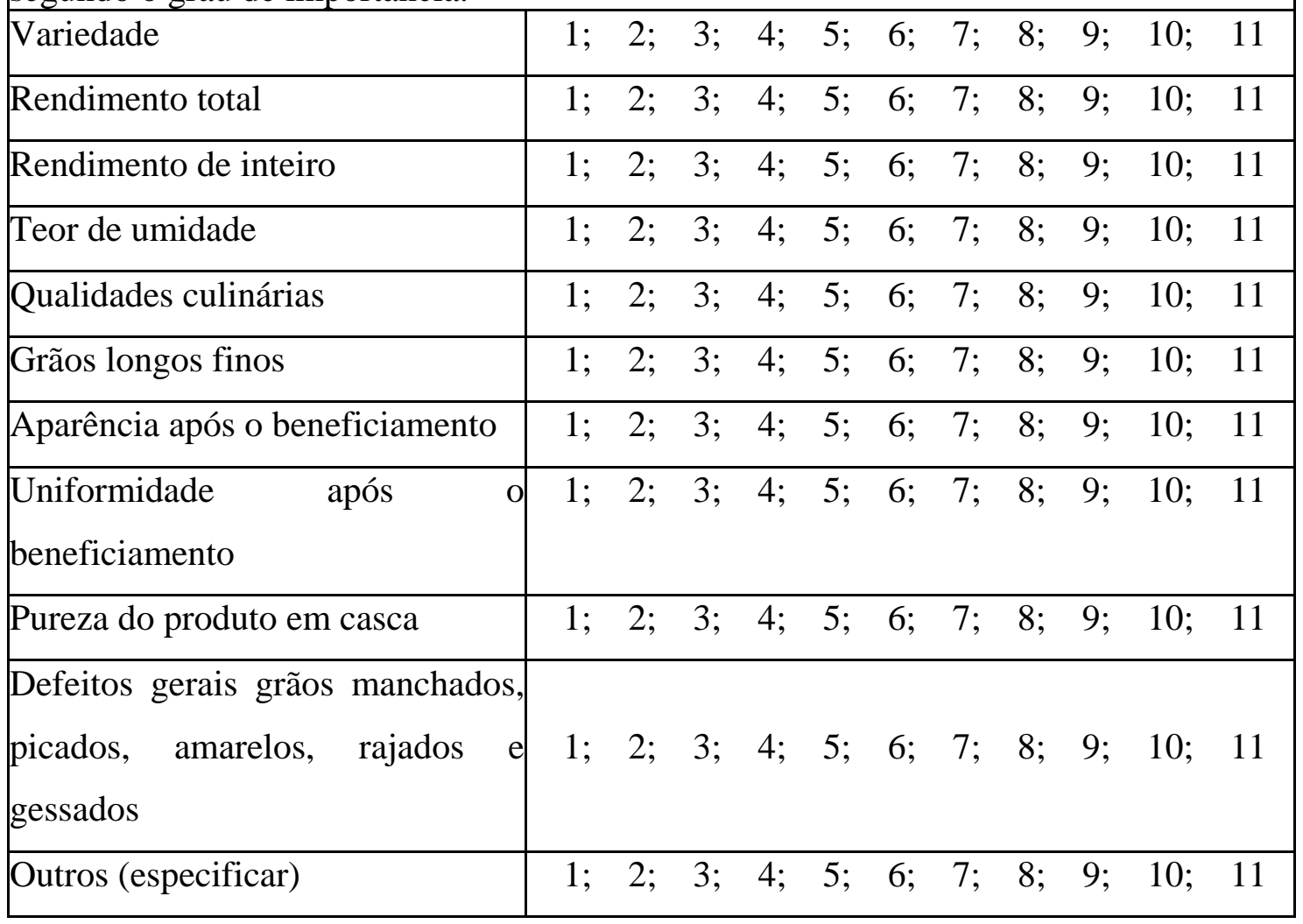




\section{4 - PERSPECTIVAS DO MERCADO}

Consumo, qualidade, preço, novos produtos.

\section{5 - ASPECTOS DA INDÚSTRIA}

Tempo de funcionamento, outros produtos comercializados, atividades desenvolvidas, volume beneficiado, ociosidade, tipos de equipamentos, investimentos futuros, custos de beneficiamento.

\section{6 - COMÉRCIO DE OUTROS PRODUTOS}

Identificar se a indústria comercializa outros produtos

a)

b)

c)

d) 


\section{REFERÊNCIAS BIBLIOGRÁFICAS}

ALVES, E.; CONTINI, E. A modernização da agricultura brasileira. In: BRANDÃO, A.S.P. (Ed.). Os principais problemas da agricultura brasileira: análise e sugestões. Brasília: PMOE/IPEA, 1992. cap.2, p.49-97.

ALVES, E. Quem ganhou e quem perdeu com a modernização da agricultura brasileira. Revista de Economia e Sociologia Rural, v.39, n.3, p.9-39, jul./set. 2001.

ALVES, L.R.A. Fontes de crescimento das principais culturas do Estado do Paraná (1981-1999). Toledo, 2000. 77p. Monografia (Graduação) - Universidade Estadual do Oeste do Paraná.

ANUÁRIO ESTATÍSTICO DO BRASIL - 2000, v.60, p.1-38, 2001.

ARAÚJO, P.F.C. de; MEYER, R.C. Política de crédito agrícola no Brasil: objetivos e resultados. In: VEIGA, A. (Coord.). Ensaios sobre política agrícola brasileira. São Paulo: Secretaria da Agricultura, 1979. p.137-162.

BAER, W. A economia brasileira. Trad. de E. Sciulli. 2.ed. São Paulo: Nobel, 2002. 509p.

BANCO CENTRAL DO BRASIL. Anuário estatístico do crédito rural. http://www.bacen.gov.br (11 ago. 2003) 
BARROS, A.L.M. de. Capital, produtividade e crescimento da agricultura: o Brasil de 1970 a 1995. Piracicaba, 1999. 149p. Tese (Doutorado) - Escola Superior de Agricultura “Luiz de Queiroz”, Universidade de São Paulo.

BARROS, J.R.M. de. Política e desenvolvimento agrícola no Brasil. In: VEIGA, A. (Coord.). Ensaios sobre política agrícola brasileira. São Paulo: Secretaria da Agricultura, 1979. p.9-36.

BARROS, J.R.M.; ÁLVARO, M. Insumos agrícolas: evolução recente e perspectivas. In: BRANDÃO, A.S.P. (Ed.). Os principais problemas da agricultura brasileira: análise e sugestões. Brasília: PMOE/IPEA, 1992. cap.8, p.295-332.

BARROS, J.R.M. de; GRAHAM, D.H. A agricultura brasileira e o problema da produção de alimentos. Pesquisa e Planejamento Econômico, v.8, n.3, p.695725. 1978.

BARROS, J.R.M. de; PASTORE, A.C.; RIZZIERI, J.A.B. A evolução da agricultura brasileira até 1970. In: ARAÚJO, P.F.C. de; SCHUH, G.E. Desenvolvimento da agricultura: estudos de casos. São Paulo: Livraria Editora Pioneira, 1983. p.257278.

BARROS, G.S.A. de C.; ARAÚJO, P.F.C. de. A política de crédito rural no Brasil: perspectivas para os anos 90. Piracicaba: FEALQ/CEPEA, 1991. 17p. (Relatório de Resultados, 9)

BELIK, W. Estado, grupos de interesse e formulação de políticas para a agropecuária brasileira. Revista de Economia e Sociologia Rural, v.36, n.1, p.9-33, jan./mar. 1998. 
BEVENUTO, A.; SOUZA, G.S. Elasticidades de demanda de produtos da lavoura brasileira. Revista de Economia e Sociologia Rural, v.32, n.1, p.47-58, jan./mar. 1994.

BOS, A.M. A produção e o consumo de alimentos básicos no Brasil. Análise Econômica, v.4, n.6, p.73-87, 1986.

BRASIL. Secretaria de Comércio Exterior. Aliceweb. http://aliceweb.mdic.gov.br (01 mar. 2003)

CAMARGO, A.M.M.P. de. Substituição regional entre as principais atividades agrícolas no Estado de São Paulo. Piracicaba, 1983. 236p. Dissertação (Mestrado) - Escola Superior de Agricultura "Luiz de Queiroz", Universidade de São Paulo.

CAMARGO, A.M.M.P. de; ANEFALOS, L.C.; CASER, D.V.; COELHO, P.J.; OLIVETTI, M.P.A. Alteração na composição da agropecuária no Estado de São Paulo, 1983-1993. Informações Econômicas, v.25, n.5, p.49-81, 1995.

CALCANHOTO, F.A.; FIALHO, M.A.V.; SOUZA, M.A.A. de. Variações da oferta de arroz no Rio Grande do Sul, no período de 1975 a 1997 (compact disc). In: CONGRESSO BRASILEIRO DE ECONOMIA E SOCIOLOGIA RURAL, 37., FOZ do Iguaçu, 1999. Anais. Brasília: SOBER, 1999.

CARDOSO, C.E.L. Efeitos de políticas públicas sobre a produção de mandioca no Brasil. Piracicaba, 1995. 180p. Dissertação (Mestrado) - Escola Superior de Agricultura “Luiz de Queiroz”, Universidade de São Paulo.

CASTRO, E. da M. de; VIEIRA, N.R. de A.; RABELO, R.R.; SILVA, S.A. da. Qualidade de grãos em arroz. Santo Antônio de Goiás: Embrapa Arroz e Feijão, 1999. 30p. 
COMPANHIA NACIONAL DE ABASTECIMENTO. Indicadores agropecuários. http://www.conab.gov.br (11 nov. 2002)

COMPANHIA NACIONAL DE ABASTECIMENTO. Safras. http://www.conab.gov.br/download/indicadores/ (25 out. 2003)

CUNHA, A.S.; DAGUER, R.J. Crescimento agrícola: area vs. produtividade. In: CONGRESSO BRASILEIRO DE ECONOMIA E SOCIOLOGIA RURAL, 20., Curitiba, 1982. Anais. Brasília: SOBER, 1982. p.329-381.

CURI, W.F. Eficiência e fontes de crescimento da agricultura mineira na dinâmica de ajustamentos da economia brasileira. Viçosa, 1997. 182p. Tese (Doutorado) Universidade Federal de Viçosa.

CURTIS, W.C. Shift-share analysis as a technique in rural development research. American Journal of Agricultural Economics, v.54, n.2, p.267-270, 1972.

DIAS, G.L. da S.; AMARAL, C.M. Mudanças estruturais na agricultura brasileira, 1980-1998. In: BAUMANN, R. (Org.) et al. Brasil: uma década em transição. Rio de Janeiro: Campus, 1999. cap.6, p.223-253.

EMBRAPA ARROZ E FEIJÃO. Arroz. http://www.cnpaf.embrapa.br (16 nov. 2003)

ESTADOS UNIDOS. Department of Agriculture. Economic Research Service. Rice outlook. http://www.ers.usda.gov (20 set. 2002)

FASSARELA, R.A. Padrões de crescimento no setor de culturas do Estado do Espírito Santo. Piracicaba, 1987. 42p. Dissertação (Mestrado) - Escola Superior de Agricultura "Luiz de Queiroz", Universidade de São Paulo. 
FAO. Faostat. http://apps.fao.org (27 Feb. 2003)

FERREIRA, C.M.; GAMEIRO, A.H.; VILLAR, P.M. del; ALMEIDA, P.N.A. Importância da cultura e entraves ao desenvolvimento do arroz de terras altas. In: CONGRESSO DA CADEIA PRODUTIVA DE ARROZ, 1.; REUNIÃO NACIONAL DE PESQUISA DE ARROZ - RENAPA, 7., Florianópolis, 2002. Anais. Santo Antônio de Goiás: Embrapa Arroz e Feijão, 2002a. p.92-95.

FERREIRA, C.M.; VILLAR, P.M. del; GAMEIRO, A.H.; ALMEIDA, P.N.A. Estratégias, impactos das políticas e entraves na comercialização do arroz de terras altas em Mato Grosso. In: CONGRESSO DA CADEIA PRODUTIVA DE ARROZ, 1.; REUNIÃO NACIONAL DE PESQUISA DE ARROZ - RENAPA, 7., Florianópolis, 2002. Anais. Santo Antônio de Goiás: Embrapa Arroz e Feijão, 2002b. p.88-91.

FERREIRA, C.M.; YOKOYAMA, L.P. Cadeia produtiva do arroz na região Centro-Oeste. Brasília: Embrapa Produção de Informação, 1999. 110p.

FUNDAÇÃO GETÚlIO VARGAS. FGV dados: informação econômica online. http://fgvdados.fgv.br (16 ago. 2003)

GAMEIRO, A.H.; VILLAR, P.M. del.; FERREIRA, C.M.; BARATA, T.S. Importações brasileiras de arroz nos últimos 10 anos. In: CONFERÊNCIA INTERNACIONAL DE ARROZ DE CLIMA TEMPERADO, 3., Punta del Leste, 2003. Anais. Punta del Leste: INIA, 2003.

GASQUES, J.G.; VERDE, C.M.V. Crescimento da agricultura brasileira e política agrícola nos anos oitenta. Agricultura em São Paulo, v.37, n.1, p.183-204, 1990. 
GHILARDI, A.A. Transformações na agricultura paulista na década de setenta, ao nível de tamanho de propriedade. São Paulo: IEA, 1987. 168p. (Relatório de pesquisa, 7/82)

GIL, A.C. Métodos e técnicas de pesquisa social. 5.ed. São Paulo: Atlas, 1999. 206p.

GOLDIN, I.; REZENDE, G.C. de. Agricultura brasileira na década de 80: crescimento numa economia em crise. Rio de Janeiro: IPEA, 1993. 119p.

GONÇALVES, J.S.; SOUZA, S.A.M. Agronegócio no Vale do Ribeira: caracterização da realidade e proposta de intervenção numa região carente. Informações Econômicas, v.31, n.1, p.39-50. jan.2001.

GONZÁLEZ-RIVERA, G.; HELFAND, S.M. Spatial relationships and market integration: the case of the brazilian rice market (compact disc). In: CONGRESSO BRASILEIRO DE ECONOMIA E SOCIOLOGIA RURAL, 37., Foz do Iguaçu, 1999. Anais. Brasília: SOBER, 1999.

GONZÁLEZ-RIVERA, G.; HELFAND, S.M. The extent, pattern, and degree of market integration: a multivariate approach for the brazilian rice market. American Journal of Agricultural Economics, v.83, n.3, p.576-592, Aug. 2001.

HAYAMI, Y.; RUTTAN, V. Diferenças de produtividade agrícola entre nações. In: ARAÚJO, P.F.C. de; SCHUH, G.E. Desenvolvimento da agricultura: educação, pesquisa e assistência técnica. São Paulo: Livraria Pioneira Editora, 1975. v.2, p.77-99. 
HOFFMANN, R. Elasticidades-renda das despesas com alimentos em regiões metropolitanas do Brasil em 1995-96. Informações Econômicas, v.30, n.2, p.1724, 2000.

IGREJA, A.C.M.; CARMO, M.S.; GALVÃO, C.A.; PELLEGRINI, R.M.P. Análise quantitativa do desempenho da agricultura paulista, 1966-77. Agricultura em São Paulo, v.30, n.1/2, p.117-157, 1983.

IGREJA, A.C.M. Evolução da pecuária bovina de corte no Estado de São Paulo no período 1969-84. Piracicaba, 1987. 197p. Dissertação (Mestrado) - Escola Superior de Agricultura “Luiz de Queiroz”, Universidade de São Paulo.

IGREJA, A.C.M.; YOKOYAMA, L.P.; ROCHA, M.B.; ALMEIDA, J. de. Cultura do arroz nos estados de Goiás e Tocantins: aspectos sócio-econômicos e tecnológicos nos sistemas de cultivo. Agricultura em São Paulo, v.42, n.2, p.6593, 1995.

INSTITUTO BRASILEIRO DE GEOGRAFIA E ESTATÍSTICA. Pesquisa de orçamentos familiares. http://www.ibge.gov.br (20 fev. 2003a)

INSTITUTO BRASILEIRO DE GEOGRAFIA E ESTATÍSTICA. Banco de dados agregados. http://sidra.ibge.gov.br (10 fev. 2003b)

INSTITUTO BRASILEIRO DE GEOGRAFIA E ESTATÍSTICA. Censo agrícola. http://www.ibge.gov.br (17 fev. 2003c)

INSTITUTO BRASILEIRO DE GEOGRAFIA E ESTATÍSTICA. Produção agrícola municipal. http://www.ibge.gov.br (20 jul. 2003d) 
INTERNATIONAL RICE RESEARCH INSTITUTE. Rice facts. Philippines, 1994. 62p.

JULIANO, B.O.; IBABAO, M.G.B.; PEREZ, C.M.; CARANGAL, V.R. Nutritional properties of nonrice crops in the Asian rice farming systems network. Plant Foods for Human Nutrition, v.36, n.72, p.273-278, 1987.

JUNQUEIRA, P. de C.; LINS, E.R. de; AMARO, A.A. Comercialização de produtos agrícolas no Estado de São Paulo. Agricultura em São Paulo, v.15, n.3/4, p.1-60, mar./abr. 1968.

LEVY, F.; GRAHAM, D.; RASK, N. Brazil: a review of agricultural policies. Washington: Lacro, 1979. 108p.

MANOEL, A.; BARROS, J.R.M. de. Agricultura brasileira: transformações e perspectivas na década de 80. In: ENCONTRO NACIONAL DE ECONOMIA, Salvador, 15., 1987. Anais. Rio de Janeiro: UFRJ/IEI/ANPEC, 1987. p.103-128.

MARTIN, N.B.; GONÇALVES, J.S.; OLIVEIRA, I.R. de; SOUZA, S.A.M. A performance da agricultura do Estado de São Paulo e das suas regiões agrícolas no pós 70. Agricultura em São Paulo, v.39, n.1, p.97-131, 1992.

MARTINS, E. Variações no consumo de alimentos no Brasil de 1974/75 a 1987/88. Piracicaba, 1998. 117p. Dissertação (M.S.) - Escola Superior de Agricultura “Luiz de Queiroz”, Universidade de São Paulo.

MARTINS, S.S.; ROCHA, M.B.; MARTINS, V.A. Evolução da comercialização do arroz em São Paulo, no período de 1975 - 2000. Informações Econômicas, v.32, n.4, p.33-40, abr. 2002. 
MELO, F.H. de. O problema alimentar no Brasil: a importância dos desequilíbrios tecnológicos. Rio de Janeiro: Paz e Terra, 1983. 226p.

MELO, F.H. de. O crescimento agrícola brasileiro dos anos 80 e as perspectivas para os anos 90. Revista de Economia Política, v.10, n.3, p.22-30, jul./set. 1990.

MESQUITA, T.C. Desempenho da agricultura brasileira e sua relação com alguns instrumentos de política econômica - 1970/1990. São Paulo, 1994. 224p. Tese (Doutorado) - Faculdade de Economia, Administração e Contabilidade, Universidade de São Paulo.

MOREIRA, C.G. Fontes de crescimento das principais culturas do Rio Grande do Norte, 1981-92. Piracicaba, 1996. 109p. Dissertação (M.S.) - Escola Superior de Agricultura “Luiz de Queiroz”, Universidade de São Paulo.

NAKANO, Y. O crédito rural num contexto de modernização da economia brasileira. In: SEMINÁRIO NACIONAL AS DIFÍCEIS OPÇÕES DO FINANCIAMENTO RURAL, Belo Horizonte, 1992. Anais. Belo Horizonte: FAEMG, 1992. p.1-18.

OLIVETTI, M.P. de A.; CAMARGO, A.M.M.P. de. Evolução da composição agrícola no Brasil e principais regiões produtoras, 1968-89. Agricultura em São Paulo, v.39, n.1, p.155-177, 1992.

PATRICK, G.F. Fontes de crescimento da agricultura brasileira: o setor de culturas. In: CONTADOR, C.R. Tecnologia e desenvolvimento agrícola. Rio de Janeiro: IPEA/INPES, 1975. p.89-110. (Série Monográfica, 17)

PESARAN, M.H.; SHIN, Y. Cointegration and speed of convergence to equilibrium. Journal of Econometrics, v.71, n.1/2, p.117-143， 1996. 
PORTUGAL, A.D. O recente sucesso da dobradinha "feijão com arroz". Revista de Política Agrícola, v.5, n.1, p.7-8, jan./fev./mar. 1996.

PORTUGAL, A.D. A importância estratégica da prospecção tecnológica para o SNPA. In: CASTRO, A.M.G.; LIMA, S.M.V.; GOEDERT, W.J. et al. (Ed.). Cadeias produtivas e sistemas naturais: prospeccção tecnológica. Brasília: Embrapa, SPI/DPD, 1998. cap.1, p.9-20.

QUEDA, O.; KAGEYAMA, A.A.; SILVA, J.F.G. Evolução recente das culturas de arroz e feijão no Brasil. Brasília: Binagri Edições, 1979. 90p.

QUIRINO, T.R. Impacto agroambiental e agenda da pesquisa agropecuária brasileira. In: CASTRO, A.M.G.; LIMA, S.M.V.; GOEDERT, W.J. et al. (Ed.). Cadeias produtivas e sistemas naturais: prospeccção tecnológica. Brasília: Embrapa, SPI/DPD, 1998. cap.3, p.61-74.

REZENDE, G.C. de. Política econômica e agricultura na década de 80 . In: CONGRESSO BRASILEIRO DE ECONOMIA E SOCIOLOGIA RURAL, 27., Piracicaba, 1989. Anais. Brasília: SOBER, 1989. p.284-309.

REZENDE, G.C. de. Integração de mercados, política de preços mínimos e expansão agrícola da região Centro-Oeste (compact disc). In: CONGRESSO BRASILEIRO DE ECONOMIA E SOCIOLOGIA RURAL, 39., Recife, 2001. Anais. Brasília: SOBER, 2001.

SANT'ANA, E.P.; CASTRO, E. da M. de; MORAIS, O.P. de; GUIMARÃES, E.P.; MOURA NETO, F.P.; BRESEGHELLO, F. BRS Bonança: cultivar de arroz semi-precoce e de alta qualidade de grão para cultivo em condições de terras altas. Santo Antônio de Goiás: Embrapa Arroz e Feijão, 2000. 2p. (Pesquisa em Foco, 35) 
SANTI, W.V.; ROCHA, D.S.; BARBOSA, T.; PANIAGO, E. Avaliação das políticas de preço mínimo e de subsídios a fertilizantes, para o caso do arroz no Brasil. Revista de Economia Rural, v.16, n.2, p.43-77, abr./jun. 1978.

SILVA, G.L.S.P. da. Produtividade, pesquisa e extensão rural. São Paulo: IPE/USP, 1984. 143p. (Série ensaios econômicos, 40)

SILVA, G.L.S.P. da. Transforming brazilian agriculture. In: CONGRESSO BRASILEIRO DE ECONOMIA E SOCIOLOGIA RURAL, 29., Campinas, 1991. Anais. Brasília: SOBER, 1991. p.254-278.

SMITH, G.W. Comercialização e desenvolvimento econômico: o estudo de um caso brasileiro 1930-1970. Estudos Econômicos, v.3, n.1, p.89-120, abr. 1973.

SMITH, G.W. A política agrícola brasileira: 1950-1967. In: ARAÚJO, P.F.C. de; SCHUH, G.E. Desenvolvimento da agricultura: estudos de casos. São Paulo: Livraria Editora Pioneira, 1983. p.213-256.

SOUZA, R.S. de; ARBAGE, A.P. Estudo sobre a viabilidade econômica do sistema de cultivo de arroz pré-germinado em relação ao convencional (compact disc). In: CONGRESSO BRASILEIRO DE ECONOMIA E SOCIOLOGIA RURAL, 40., Passo Fundo, 2002. Anais. Brasília: SOBER, 2002.

STEINMETZ, S. Sistemas de produção de arroz de sequeiro e várzeas no Brasil. In: CONFERÊNCIA DEL IRTP PARA AMÉRICA LATINA, 5., Cali, 1983. Anais. Cali: CIAT, 1983. p.125-135.

VEIGA FILHO, A.A.; YOSHII, R.J. Uso da terra no Estado de São Paulo: mudanças na composição das atividades agrícolas e o caso da cana para indústria. Informações Econômicas, v.22, n.2, p.45-53, fev. 1992. 
VERA FILHO, F.; TOLLINI, H. Progresso tecnológico e desenvolvimento agrícola. In: VEIGA, A. Ensaios sobre política agrícola brasileira. São Paulo: Secretaria da Agricultura, 1979. p.87-136.

VILLAR, P.M. del; FERREIRA, C.M. Arroz de terras altas e as dinâmicas agrícolas em Mato Grosso. In: CONGRESSO DA CADEIA PRODUTIVA DE ARROZ, 1.; REUNIÃO NACIONAL DE PESQUISA DE ARROZ - RENAPA, 7., Florianópolis, 2002. Anais. Santo Antônio de Goiás: Embrapa Arroz e Feijão, 2002. p.80-83.

VILLAR, P.M. del; FERREIRA, C.M.; GAMEIRO, A.H.; ALMEIDA, P.N.A. Arroz de terras altas em Mato Grosso: evolução tecnológica e dinâmica territorial. Santo Antônio de Goiás: Embrapa Arroz e Feijão, 2002a. 23p. (Documentos, 143)

VILLAR, P.M. del; FERREIRA, C.M.; GAMEIRO, A.H.; ALMEIDA, P.N.A. Desempenho das cultivares de arroz de terras altas no Mato Grosso com ênfase nas exigências do mercado. In: CONGRESSO DA CADEIA PRODUTIVA DE ARROZ, 1.; REUNIÃO NACIONAL DE PESQUISA DE ARROZ - RENAPA, 7., Florianópolis, 2002. Anais. Santo Antônio de Goiás: Embrapa Arroz e Feijão, 2002b. p.84-87.

VILLAR, P.M. del; GAMEIRO, A.H.; FERREIRA, C.M. Competitividade entre o arroz irrigado e de terras altas no Brasil. In: CONFERENCIA INTERNACIONAL DE ARROZ DE ClimA TEMPERADO, 3., Punta del Leste, 2003. Anais. Punta del Leste: INIA, 2003.

YOKOYAMA, L.P. O crescimento da produção e modernização das lavouras em Goiás no período 1975-1984. Piracicaba, 1988. 109p. Dissertação (Mestrado) Escola Superior de Agricultura “Luiz de Queiroz”, Universidade de São Paulo. 
YOKOYAMA, L.P. O arroz no Brasil no período de 1985/86 a 1999/00: aspectos conjunturais. In: CONGRESSO DA CADEIA PRODUTIVA DE ARROZ, 1.; REUNIÃO NACIONAL DE PESQUISA DE ARROZ - RENAPA, 7., Florianópolis, 2002. Anais. Santo Antônio de Goiás: Embrapa Arroz e Feijão, 2002. p.96-99.

ZOCKUN, M.H.G.P. A expansão da soja no Brasil: alguns aspectos da produção. São Paulo, 1978. 228p. Dissertação (Mestrado) - Faculdade de Economia e Administração, Universidade de São Paulo. 
APÊNDICES 
APÊNDICE 1 - Descreve-se a relação das microrregiões e seus respectivos municípios do Estado do Mato Grosso.

\section{Alta Floresta}

Alta Floresta

Apiacás

Carlinda

Nova Bandeirantes

Nova Monte Verde

Paranaíta

\section{Alto Pantanal}

Barão de Melgaço

Cáceres

Curvelândia

Poconé

\section{Alto Teles Pires}

Lucas do Rio Verde

Nobres

Nova Mutum

Nova Ubiratã

Santa Rita do Trivelato

Sorriso

Tapurah

\section{Paranatinga}

Gaúcha do Norte

Nova Brasilândia

Paranatinga

Planalto da Serra

\section{Alto Araguaia}

Alto Araguaia

Alto Garças

Alto Taquari

\section{Alto Guaporé}

Conquista D’Oeste

Nova Lacerda

Pontes e Lacerda

Vale de São Domingos

Vila Bela da Santíssima Trindade

\section{Alto Paraguai}

Alto Paraguai

Arenápolis

Nortelândia

Nova Marilândia

Santo Afonso

Arinos

Juara

Nova Maringá

Novo Horizonte do Norte

Porto dos Gaúchos

São José do Rio Claro

Tabaporã 


\section{Aripuanã}

Aripuanã

Brasnorte

Castanheira

Colniza

Cotriguaçu

Juína

Juruena

Rondolândia

Colíder

Colíder

Guarantã do Norte

Matupá

Nova Canaã do Norte

Nova Guarita

Novo Mundo

Peixoto de Azevedo

Terra Nova do Norte

\section{Parecis}

Campo Novo do Parecis

Campos de Júlio

Comodoro

Diamantino

Sapezal

\section{Rosário Oeste}

Acorizal

Jangada

Rosário Oeste

\section{Canarana}

Água Boa

Campinápolis

Canarana

Nova Nazaré

Nova Xavantina

Novo São Joaquim

Querência

Santo Antônio do Leste

\section{Cuiabá}

Chapada dos Guimarães

Cuiabá

Nossa Senhora do Livramento

Santo Antônio do Leverger

Várzea Grande

\section{Médio Araguaia}

Araguaiana

Barra do Garças

Cocalinho

\section{Primavera do Leste}

Campo Verde

Primavera do Leste

\section{Tangará da Serra}

Barra do Bugres

Denise

Nova Olímpia

Porto Estrela

Tangará da Serra 


\section{Jauru}

Araputanga

Figueirópolis D’Oeste

Glória D’Oeste

Indiavaí

Jauru

Lambari D’Oeste

Mirassol D’Oeste

Porto Esperidião

Reserva do Cabaçal

Rio Branco

Salto do Céu

São José dos Quatro Marcos

Sinop

Cláudia

Feliz Natal

Itaúba

Marcelândia

Nova Santa Helena

Santa Carmem

Sinop

União do Sul

\section{Norte Araguaia}

Alto Boa Vista

Bom Jesus do Araguaia

Canabrava do Norte

Confresa

Luciára

Novo Santo Antônio

Porto Alegre do Norte

Ribeirão Cascalheira

Santa Cruz do Xingu

Santa Teresinha

São Félix do Araguaia

São José do Xingu

Serra Nova Dourada

Vila Rica

\section{Rondonópolis}

Dom Aquino

Itiquira

Jaciara

Juscimeira

Pedra Preta

Rondonópolis

São José do Povo

São Pedro da Cipa 


\section{Tesouro}

Araguainha

General Carneiro

Guiratinga

Pontal do Araguaia

Ponte Branca

Poxoréo

Ribeirãozinho

Tesouro

Torixoréu

Tem-se na Figura 26 o mapa do Estado do Mato Grosso identificando suas microrregiões. 


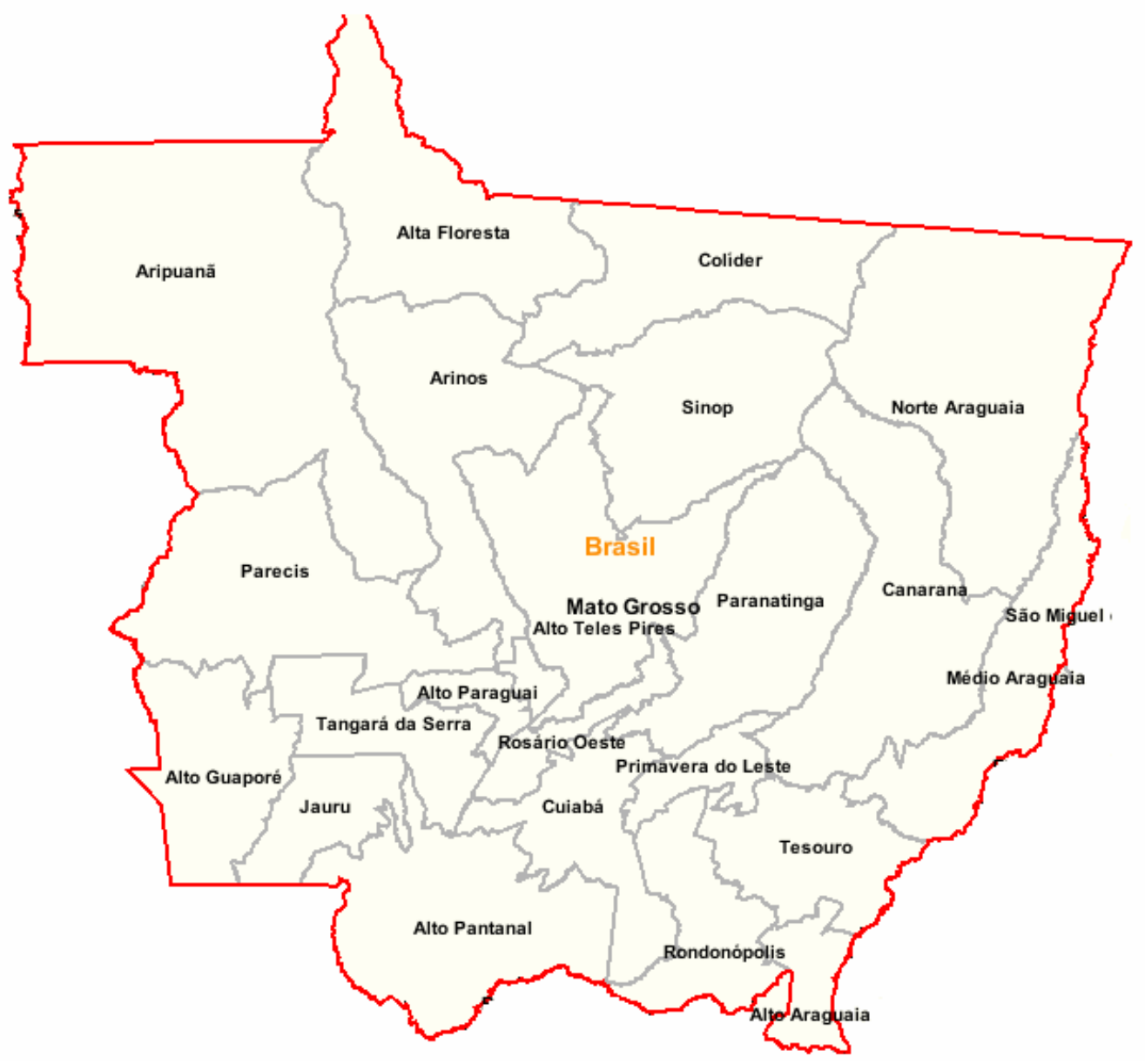

Figura 26 - Mapa do Mato Grosso com suas respectivas microrregiões. 
APÊNDICE 2 - Série de dados de área (ha) e rendimento (kg/ha) de algodão, da média móvel trienal para os anos de 1980, 1985, 1990, 1995 e 2000.

\begin{tabular}{|c|c|c|c|c|c|c|}
\hline \multirow{2}{*}{ Microrregiões } & \multicolumn{2}{|c|}{1980} & \multicolumn{2}{|c|}{1985} & \multicolumn{2}{|c|}{1990} \\
\hline & Área & Rendim. & Área & Rendim. & Área & Rendim. \\
\hline MR-1 & 0 & 0 & 0 & 0 & 627 & 1.036 \\
\hline MR-2 & 0 & 0 & 0 & 0 & 778 & 1.176 \\
\hline MR-3 & 333 & 300 & 617 & 1.422 & 11.402 & 1.159 \\
\hline MR-4 & 0 & 0 & 0 & 0 & 0 & 0 \\
\hline MR-5 & 0 & 0 & 10 & 144 & 39 & 500 \\
\hline MR-6 & 8 & 333 & 0 & 0 & 6.721 & 1.695 \\
\hline MR-7 & 3 & 333 & 957 & 997 & 703 & 1.112 \\
\hline MR-8 & 0 & 0 & 0 & 0 & 1.753 & 773 \\
\hline MR-9 & 0 & 0 & 0 & 0 & 0 & 0 \\
\hline MR-10 & 38 & 699 & 21 & 339 & 375 & 1.037 \\
\hline MR-11 & 0 & 0 & 0 & 0 & 84 & 1.349 \\
\hline MR-12 & 296 & 626 & 388 & 1.590 & 2.813 & 1.479 \\
\hline MR-13 & 0 & 0 & 0 & 0 & 18 & 843 \\
\hline MR-14 & 2.401 & 882 & 6.261 & 1.418 & 6.053 & 1.262 \\
\hline MR-15 & 735 & 1.182 & 2.202 & 1.091 & 13.225 & 1.369 \\
\hline MR-16 & 6 & 592 & 85 & 1.291 & 90 & 200 \\
\hline MR-17 & 0 & 0 & 0 & 0 & 0 & 0 \\
\hline MR-18 & 550 & 1.221 & 2.242 & 1.044 & 4.704 & 1.201 \\
\hline MR-19 & 2 & 333 & 296 & 829 & 1.947 & 840 \\
\hline MR-20 & 0 & 0 & 0 & 0 & 0 & 0 \\
\hline MR-21 & 100 & 1.000 & 0 & 0 & 81 & 1.072 \\
\hline MR-22 & 33 & 250 & 4 & 179 & 162 & 1.516 \\
\hline Estado & 4.506 & 975 & 13.083 & 1.282 & 51.574 & 1.213 \\
\hline
\end{tabular}


APÊNDICE 2 - Série de dados de área (ha) e rendimento (kg/ha) de algodão, da média móvel trienal para os anos de 1980, 1985, 1990, 1995 e 2000.

\begin{tabular}{|c|c|c|c|c|}
\hline \multirow{2}{*}{ Microrregiões } & \multicolumn{2}{|c|}{1995} & \multicolumn{2}{|c|}{2000} \\
\hline & Área & Rendimento & Área & Rendimento \\
\hline MR-1 & 413 & 1.479 & 43.715 & 3.262 \\
\hline MR-2 & 190 & 1.061 & 3.217 & 3.431 \\
\hline MR-3 & 9.119 & 859 & 1.594 & 1.577 \\
\hline MR-4 & 505 & 1.300 & 30.012 & 3.342 \\
\hline MR-5 & 160 & 1.500 & 64 & 2.175 \\
\hline MR-6 & 2.542 & 2.360 & 64.734 & 3.440 \\
\hline MR-7 & 265 & 1.092 & 4.578 & 3.152 \\
\hline MR-8 & 2.209 & 793 & 317 & 1.170 \\
\hline MR-9 & 30 & 886 & 6 & 490 \\
\hline MR-10 & 456 & 1.311 & 4.172 & 3.615 \\
\hline MR-11 & 170 & 713 & 52 & 1.899 \\
\hline MR-12 & 1.623 & 1.350 & 740 & 3.016 \\
\hline MR-13 & 1.011 & 1.528 & 55.787 & 3.962 \\
\hline MR-14 & 14.486 & 1.688 & 61.517 & 3.879 \\
\hline MR-15 & 21.077 & 1.113 & 1.989 & 1.721 \\
\hline MR-16 & 923 & 1.513 & 6.497 & 3.496 \\
\hline MR-17 & 0 & 0 & 0 & 0 \\
\hline MR-18 & 6.051 & 1.108 & 197 & 1.500 \\
\hline MR-19 & 1.946 & 1.135 & 298 & 1.608 \\
\hline MR-20 & 7 & 400 & 9.067 & 4.265 \\
\hline MR-21 & 8 & 1.067 & 1.533 & 1.954 \\
\hline MR-22 & 317 & 1.369 & 3 & 250 \\
\hline Estado & 63.508 & 1.327 & 290.086 & 3.630 \\
\hline
\end{tabular}


APÊNDICE 2 - Série de dados de área (ha) e rendimento ( $\mathrm{kg} / \mathrm{ha}$ ) de arroz, da média móvel trienal para os anos de 1980, 1985, 1990, 1995 e 2000.

\begin{tabular}{|c|c|c|c|c|c|c|}
\hline \multirow{2}{*}{ Microrregiões } & \multicolumn{2}{|c|}{1980} & \multicolumn{2}{|c|}{1985} & \multicolumn{2}{|c|}{1990} \\
\hline & Área & Rendim. & Área & Rendim. & Área & Rendim. \\
\hline$\overline{\text { MR-1 }}$ & 35.661 & 1.400 & 30.895 & 1.240 & 33.690 & 1.600 \\
\hline MR-2 & 1.167 & 300 & 14.518 & 1.427 & 11.459 & 1.416 \\
\hline MR-3 & 5.640 & 500 & 40.403 & 1.262 & 25.880 & 1.356 \\
\hline MR-4 & 42.621 & 197 & 44.599 & 1.025 & 77.032 & 1.207 \\
\hline MR-5 & 9.243 & 453 & 29.173 & 1.099 & 25.890 & 1.522 \\
\hline MR-6 & 77.289 & 1.400 & 46.451 & 1.155 & 59.850 & 1.562 \\
\hline MR-7 & 4.597 & 1.640 & 14.083 & 1.256 & 12.537 & 1.398 \\
\hline MR-8 & 1.097 & 500 & 9.893 & 1.471 & 10.507 & 1.239 \\
\hline MR-9 & 12.388 & 1.234 & 27.019 & 1.350 & 31.131 & 1.236 \\
\hline MR-10 & 4.860 & 1.500 & 13.656 & 1.817 & 17.919 & 1.512 \\
\hline MR-11 & 14.362 & 1.383 & 6.686 & 1.225 & 3.490 & 1.107 \\
\hline MR-12 & 25.131 & 1.466 & 9.987 & 1.452 & 12.772 & 1.636 \\
\hline MR-13 & 0 & 0 & 0 & 0 & 17.417 & 1.372 \\
\hline MR-14 & 144.902 & 1.170 & 36.704 & 1.251 & 12.052 & 1.139 \\
\hline MR-15 & 36.090 & 1.540 & 26.507 & 1.513 & 16.756 & 1.483 \\
\hline MR-16 & 67.109 & 1.154 & 30.590 & 1.106 & 11.023 & 1.144 \\
\hline MR-17 & 168.452 & 1.103 & 20.791 & 996 & 14.112 & 1.314 \\
\hline MR-18 & 37.748 & 1.463 & 40.558 & 1.211 & 10.692 & 1.065 \\
\hline MR-19 & 7.569 & 1.540 & 17.914 & 1.335 & 4.424 & 1.419 \\
\hline MR-20 & 26.495 & 1.108 & 7.716 & 1.164 & 3.458 & 1.224 \\
\hline MR-21 & 97.110 & 1.316 & 32.781 & 1.330 & 6.967 & 1.294 \\
\hline MR-22 & 13.677 & 1.395 & 15.144 & 1.433 & 4.659 & 1.523 \\
\hline Estado & 833.207 & 1.237 & 516.065 & 1.242 & 423.716 & 1.390 \\
\hline
\end{tabular}


APÊNDICE 2 - Série de dados de área (ha) e rendimento ( $\mathrm{kg} / \mathrm{ha}$ ) de arroz, da média móvel trienal para os anos de 1980, 1985, 1990, 1995 e 2000.

\begin{tabular}{|c|c|c|c|c|}
\hline \multirow{2}{*}{ Microrregiões } & \multicolumn{2}{|c|}{1995} & \multicolumn{2}{|c|}{2000} \\
\hline & Área & Rendimento & Área & Rendimento \\
\hline MR-1 & 82.900 & 2.009 & 145.291 & 2.788 \\
\hline MR-2 & 12.323 & 2.307 & 59.042 & 2.921 \\
\hline MR-3 & 21.516 & 1.545 & 55.515 & 2.930 \\
\hline MR-4 & 66.149 & 1.630 & 52.076 & 2.295 \\
\hline MR-5 & 47.417 & 1.509 & 60.122 & 2.116 \\
\hline MR-6 & 62.383 & 1.866 & 88.473 & 2.494 \\
\hline MR-7 & 10.671 & 1.907 & 21.167 & 2.721 \\
\hline MR-8 & 17.909 & 1.872 & 26.703 & 2.666 \\
\hline MR-9 & 19.087 & 1.430 & 23.827 & 1.663 \\
\hline MR-10 & 9.235 & 2.087 & 15.014 & 2.133 \\
\hline MR-11 & 2.426 & 1.574 & 9.398 & 3.023 \\
\hline MR-12 & 8.099 & 1.860 & 12.890 & 2.561 \\
\hline MR-13 & 13.347 & 1.634 & 15.648 & 2.032 \\
\hline MR-14 & 16.892 & 1.484 & 7.612 & 1.986 \\
\hline MR-15 & 7.349 & 1.589 & 5.528 & 1.796 \\
\hline MR-16 & 13.810 & 1.537 & 7.535 & 1.819 \\
\hline MR-17 & 11.250 & 1.594 & 4.985 & 1.741 \\
\hline MR-18 & 4.388 & 1.438 & 3.477 & 1.881 \\
\hline MR-19 & 3.506 & 1.451 & 2.907 & 1.848 \\
\hline MR-20 & 2.382 & 1.575 & 2.968 & 2.337 \\
\hline MR-21 & 5.310 & 1.378 & 3.111 & 1.724 \\
\hline MR-22 & 2.554 & 1.539 & 1.913 & 1.664 \\
\hline Estado & 440.901 & 1.740 & 625.204 & 2.522 \\
\hline
\end{tabular}


APÊNDICE 2 - Série de dados de área (ha) e rendimento (kg/ha) de milho, da média móvel trienal para os anos de 1980, 1985, 1990, 1995 e 2000.

\begin{tabular}{|c|c|c|c|c|c|c|}
\hline \multirow{2}{*}{ Microrregiões } & \multicolumn{2}{|c|}{1980} & \multicolumn{2}{|c|}{1985} & \multicolumn{2}{|c|}{1990} \\
\hline & Área & Rendim. & Área & Rendim. & Área & Rendim. \\
\hline MR-1 & 980 & 1.200 & 1.308 & 1.900 & 14.659 & 2.652 \\
\hline MR-2 & 200 & 500 & 1.753 & 1.278 & 3.747 & 1.596 \\
\hline MR-3 & 2.000 & 500 & 58.574 & 1.302 & 33.184 & 1.577 \\
\hline MR-4 & 804 & 500 & 15.092 & 1.845 & 13.100 & 2.256 \\
\hline MR-5 & 1.433 & 549 & 2.898 & 1.589 & 4.032 & 1.674 \\
\hline MR-6 & 1.533 & 1.320 & 4.500 & 2.833 & 22.050 & 2.705 \\
\hline MR-7 & 867 & 1.400 & 16.055 & 1.618 & 13.067 & 1.880 \\
\hline MR-8 & 433 & 500 & 4.777 & 1.793 & 8.315 & 1.610 \\
\hline MR-9 & 3.847 & 1.485 & 7.761 & 1.690 & 18.156 & 1.711 \\
\hline MR-10 & 2.239 & 1.700 & 14.909 & 2.425 & 11.995 & 2.209 \\
\hline MR-11 & 2.810 & 1.500 & 1.233 & 1.803 & 1.924 & 2.095 \\
\hline MR-12 & 7.370 & 1.450 & 8.097 & 1.927 & 15.497 & 2.706 \\
\hline MR-13 & 0 & 0 & 0 & 0 & 14.717 & 3.279 \\
\hline MR-14 & 8.367 & 1.617 & 13.641 & 2.364 & 30.123 & 3.815 \\
\hline MR-15 & 15.153 & 1.854 & 30.456 & 1.742 & 27.649 & 2.029 \\
\hline MR-16 & 5.509 & 1.553 & 4.288 & 1.871 & 5.772 & 3.090 \\
\hline MR-17 & 3.500 & 1.600 & 2.061 & 1.538 & 7.610 & 2.471 \\
\hline MR-18 & 10.661 & 1.684 & 18.427 & 1.559 & 11.729 & 1.707 \\
\hline MR-19 & 8.383 & 1.800 & 18.733 & 1.710 & 7.767 & 1.726 \\
\hline MR-20 & 713 & 1.389 & 3.110 & 2.982 & 10.915 & 4.556 \\
\hline MR-21 & 10.019 & 1.568 & 10.371 & 1.557 & 7.290 & 1.775 \\
\hline MR-22 & 2.877 & 1.324 & 2.146 & 1.476 & 3.427 & 2.024 \\
\hline Estado & 89.698 & 1.644 & 240.190 & 1.746 & 286.723 & 2.426 \\
\hline
\end{tabular}


APÊNDICE 2 - Série de dados de área (ha) e rendimento ( $\mathrm{kg} / \mathrm{ha}$ ) de milho, da média móvel trienal para os anos de 1980, 1985, 1990, 1995 e 2000.

\begin{tabular}{|c|c|c|c|c|}
\hline \multirow{2}{*}{ Microrregiões } & \multicolumn{2}{|c|}{1995} & \multicolumn{2}{|c|}{2000} \\
\hline & Área & Rendimento & Área & Rendimento \\
\hline MR-1 & 95.430 & 2.197 & 159.878 & 2.574 \\
\hline MR-2 & 8.079 & 2.298 & 12.823 & 2.713 \\
\hline MR-3 & 30.802 & 1.792 & 13.212 & 2.807 \\
\hline MR-4 & 18.504 & 2.860 & 18.075 & 2.762 \\
\hline MR-5 & 5.000 & 1.804 & 2.161 & 2.117 \\
\hline MR-6 & 48.020 & 3.016 & 59.324 & 2.403 \\
\hline MR-7 & 5.696 & 2.699 & 9.428 & 2.877 \\
\hline MR-8 & 10.300 & 1.996 & 8.843 & 2.681 \\
\hline MR-9 & 17.240 & 1.847 & 23.613 & 2.067 \\
\hline MR-10 & 14.080 & 2.850 & 18.585 & 2.375 \\
\hline MR-11 & 1.633 & 2.368 & 4.540 & 2.651 \\
\hline MR-12 & 9.310 & 2.937 & 8.810 & 3.763 \\
\hline MR-13 & 60.836 & 3.447 & 56.719 & 3.552 \\
\hline MR-14 & 59.454 & 3.574 & 38.169 & 2.993 \\
\hline MR-15 & 22.208 & 2.546 & 16.117 & 2.882 \\
\hline MR-16 & 13.162 & 2.982 & 16.192 & 3.327 \\
\hline MR-17 & 1.338 & 2.486 & 997 & 2.596 \\
\hline MR-18 & 8.250 & 1.935 & 5.807 & 2.775 \\
\hline MR-19 & 10.892 & 2.150 & 6.233 & 2.775 \\
\hline MR-20 & 22.153 & 3.951 & 19.762 & 4.254 \\
\hline MR-21 & 7.297 & 1.993 & 5.367 & 2.509 \\
\hline MR-22 & 2.561 & 1.838 & 1.620 & 1.944 \\
\hline Estado & 472.244 & 2.756 & 506.275 & 2.826 \\
\hline
\end{tabular}


APÊNDICE 2 - Série de dados de área (ha) e rendimento (kg/ha) de soja, da média móvel trienal para os anos de 1980, 1985, 1990, 1995 e 2000.

\begin{tabular}{|c|c|c|c|c|c|c|}
\hline \multirow{2}{*}{ Microrregiões } & \multicolumn{2}{|c|}{1980} & \multicolumn{2}{|c|}{1985} & \multicolumn{2}{|c|}{1990} \\
\hline & Área & Rendim. & Área & Rendim. & Área & Rendim. \\
\hline$\overline{\text { MR-1 }}$ & 522 & 1.299 & 69.362 & 2.160 & 296.663 & 2.156 \\
\hline MR-2 & 0 & 0 & 1.985 & 1.893 & 9.141 & 1.973 \\
\hline MR-3 & 0 & 0 & 103 & 889 & 3 & 600 \\
\hline MR-4 & 730 & 433 & 40.323 & 1.639 & 117.925 & 1.860 \\
\hline MR-5 & 1.386 & 552 & 4.379 & 1.660 & 8.833 & 1.841 \\
\hline MR-6 & 1.149 & 1.360 & 147.050 & 2.120 & 333.328 & 2.145 \\
\hline MR-7 & 17 & 333 & 2.667 & 2.100 & 11.533 & 2.129 \\
\hline MR-8 & 0 & 0 & 0 & 0 & 36 & 364 \\
\hline MR-9 & 0 & 0 & 734 & 1.492 & 2.520 & 1.619 \\
\hline MR-10 & 0 & 0 & 0 & 0 & 16.996 & 2.233 \\
\hline MR-11 & 112 & 833 & 6.515 & 1.770 & 10.367 & 1.966 \\
\hline MR-12 & 31 & 500 & 9.908 & 1.690 & 18.992 & 2.108 \\
\hline MR-13 & 0 & 0 & 0 & 0 & 219.494 & 2.320 \\
\hline MR-14 & 36.481 & 1.674 & 203.269 & 2.140 & 235.743 & 2.357 \\
\hline MR-15 & 33 & 317 & 620 & 1.824 & 85 & 1.361 \\
\hline MR-16 & 3.383 & 1.450 & 82.213 & 1.976 & 65.191 & 2.173 \\
\hline MR-17 & 450 & 744 & 11.909 & 1.933 & 8.699 & 1.942 \\
\hline MR-18 & 109 & 499 & 2.649 & 1.708 & 371 & 2.110 \\
\hline MR-19 & 0 & 0 & 1.503 & 1.677 & 33 & 667 \\
\hline MR-20 & 14.285 & 1.766 & 86.082 & 2.041 & 93.316 & 2.384 \\
\hline MR-21 & 11.070 & 1.544 & 72.073 & 2.000 & 9.891 & 2.060 \\
\hline MR-22 & 125 & 400 & 5.600 & 1.966 & 6.167 & 2.187 \\
\hline Estado & 69.833 & 1.758 & 748.943 & 2.059 & 1.465 .329 & 2.183 \\
\hline
\end{tabular}


APÊNDICE 2 - Série de dados de área (ha) e rendimento (kg/ha) de milho, da média móvel trienal para os anos de 1980, 1985, 1990, 1995 e 2000.

\begin{tabular}{|c|c|c|c|c|}
\hline \multirow{2}{*}{ Microrregiões } & \multicolumn{2}{|c|}{1995} & \multicolumn{2}{|c|}{2000} \\
\hline & $\overline{\text { Área }}$ & Rendimento & Área & Rendimento \\
\hline MR-1 & 493.827 & 2.535 & 841.893 & 3.025 \\
\hline MR-2 & 12.884 & 2.384 & 35.304 & 2.880 \\
\hline MR-3 & 27 & 1.517 & 1.507 & 2.738 \\
\hline MR-4 & 170.358 & 2.407 & 194.071 & 2.953 \\
\hline MR-5 & 6.657 & 2.198 & 13.563 & 2.770 \\
\hline MR-6 & 575.235 & 2.554 & 831.071 & 2.920 \\
\hline MR-7 & 25.852 & 2.314 & 51.289 & 2.765 \\
\hline MR-8 & 0 & 0 & 267 & 1.800 \\
\hline MR-9 & 0 & 0 & 584 & 2.132 \\
\hline MR-10 & 22.034 & 2.583 & 56.076 & 2.873 \\
\hline MR-11 & 15.965 & 2.252 & 18.754 & 2.725 \\
\hline MR-12 & 28.964 & 2.573 & 26.014 & 2.868 \\
\hline MR-13 & 258.657 & 2.550 & 256.808 & 3.064 \\
\hline MR-14 & 271.563 & 2.584 & 267.055 & 3.004 \\
\hline MR-15 & 607 & 1.293 & 92 & 1.416 \\
\hline MR-16 & 102.361 & 2.423 & 140.321 & 2.892 \\
\hline MR-17 & 3.161 & 2.084 & 3.434 & 2.450 \\
\hline MR-18 & 133 & 700 & 52 & 667 \\
\hline MR-19 & 368 & 1.333 & 693 & 2.933 \\
\hline MR-20 & 105.146 & 2.485 & 139.026 & 3.013 \\
\hline MR-21 & 6.108 & 2.501 & 8.253 & 2.553 \\
\hline MR-22 & 737 & 1.611 & 1.475 & 2.529 \\
\hline Estado & 2.100 .643 & 2.514 & 2.887 .604 & 2.976 \\
\hline
\end{tabular}


APÊNDICE 3 - Memória de cálculo.

Apresenta-se primeiramente a memória de cálculo referente ao estudo da decomposição do efeito área em efeito escala e substituição. Em seguida apresentam-se os dados inerentes à análise individual das culturas no estado, análise do conjunto de culturas por microrregião e estado. O capítulo 3 descreve a metodologia “shift-share”, para a obtenção dos resultados aqui apresentados. Os valores de área estão descritos em hectares e os de produção, em toneladas.

Apresentam-se os dados para a cultura do algodão.

\section{Decomposição do efeito área em efeitos escala e substituição no subperíodo.}

1980-1985:
$A_{C i}=4.506$
$A_{c f}=13.083$
$A_{i}=997.295$
$A_{f}=1.518 .281$
$\lambda=1,522398246$

1985-1990:
$A_{c i}=13.083$
$A_{c f}=51.574$
$A_{i}=1.518 .281$
$A_{f}=2.227 .343$
$\lambda=1,467016419$

1990-1995:
$A_{c i}=51.574$
$A_{c f}=63.508$
$A_{i}=2.227 .343$
$A_{f}=3.077 .295$
$\lambda=1,381599419$

1995-2000:
$A_{c i}=63.508$
$A_{c f}=290.086$
$A_{i}=3.077 .295$
$A_{f}=4.309 .169$
$\lambda=1,400310511$ 
1980-2000:
$A_{c i}=4.506$
$A_{c f}=290.086$
$A_{i}=997.295$
$A_{f}=4.309 .169$
$\lambda=4,320855474$

\section{Análise individual da cultura do algodão}

1980-1985:
$A_{c i}=4.506$
$A_{c f}=13.083$
$Q_{c i}=4.086$
$Q_{c f}=16.431$
$Q_{c f}^{A}=11.863$
$Q_{c f}^{A R}=16.709$
$Q_{c f}^{A R L}=16.430$

1985-1990:
$A_{c i}=13.083$
$A_{c f}=51.574$
$Q_{C i}=16.431$
$Q_{c f}=66.389$
$Q_{c f}^{A}=46.765$
$Q_{c f}^{A R}=64.111$
$Q_{c f}^{A R L}=66.389$

1990-1995:
$A_{c i}=51.574$
$A_{c f}=63.508$
$Q_{C i}=66.389$
$Q_{c f}=80.724$
$Q_{c f}^{A}=81.751$
$Q_{C f}^{A R}=82.256$
$Q_{c f}^{A R L}=80.724$

1995-2000:
$A_{c i}=63.508$
$A_{c f}=290.086$
$Q_{c i}=80.724$
$Q_{c f}=1.039 .734$
$Q_{c f}^{A}=368.724$
$Q_{c f}^{A R}=682.777$
$Q_{c f}^{A R L}=1.039 .734$ 
1980-2000:
$A_{c i}=4.506$
$A_{c f}=290.086$
$Q_{C i}=4.086$
$Q_{c f}=1.039 .734$
$Q_{c f}^{A}=263.038$
$Q_{C f}^{A R}=851.385$
$Q_{c f}^{A R L}=1.039 .734$

Apresentam-se os dados para a cultura do arroz.

Decomposição do efeito área em efeitos escala e substituição no subperíodo.

1980-1985:
$A_{c i}=833.207$
$A_{c f}=516.065$
$A_{i}=997.295$
$A_{f}=1.518 .281$
$\lambda=1,5224$

1985-1990:

$A_{c i}=516.065$

$A_{c f}=423.716$

$A_{i}=1.518 .281$

$A_{f}=2.227 .343$

$\lambda=1,46702$

1990-1995:
$A_{c i}=423.716$
$A_{c f}=440.901$
$A_{i}=2.227 .343$
$A_{f}=3.077 .295$
$\lambda=1,3816$

1995-2000:

$$
A_{c i}=440.901
$$

$A_{c f}=625.204$

$A_{i}=3.077 .295$

$A_{f}=4.309 .169$

$\lambda=1,40031$

1980-2000:
$A_{C i}=833.207$
$A_{c f}=625.204$ 
$A_{i}=997.295$

$A_{f}=4.309 .169$

$\lambda=4,32086$

\section{Análise individual da cultura do arroz}

1980-1985:

$$
\begin{aligned}
& A_{c i}=833.207 \\
& Q_{C i}=992.781 \\
& Q_{c f}^{A}=614.900
\end{aligned}
$$$$
A_{c f}=516.065
$$$$
Q_{c f}=645.556
$$

$Q_{c f}^{A R}=617.172$

$Q_{c f}^{A R L}=645.556$

1985-1990:

$$
\begin{aligned}
& A_{c i}=516.065 \\
& Q_{C i}=645.556 \\
& Q_{c f}^{A}=530.035
\end{aligned}
$$$$
A_{c f}=423.716
$$$$
Q_{c f}=583.566
$$

$Q_{c f}^{A R}=568.383$

$Q_{c f}^{A R L}=583.566$

1990-1995:
$A_{c i}=423.716$
$A_{c f}=440.901$
$Q_{C i}=583.566$
$Q_{c f}=767.436$
$Q_{c f}^{A}=607.233$
$Q_{c f}^{A R}=750.835$
$Q_{c f}^{A R L}=767.436$

1995-2000:
$A_{c i}=440.901$
$A_{c f}=625.204$
$Q_{C i}=767.436$
$Q_{C f}=1.576 .065$
$Q_{c f}^{A}=1.088 .237$
$Q_{c f}^{A R}=1.483 .895$
$Q_{c f}^{A R L}=1.576 .065$

1980-2000:
$A_{c i}=833.207$
$A_{c f}=625.204$ 


$$
\begin{aligned}
& Q_{C i}=992.781 \\
& Q_{c f}=1.576 .065 \\
& Q_{c f}^{A}=744.941 \\
& Q_{c f}^{A R}=1.267 .208 \\
& Q_{c f}^{A R L}=1.576 .065
\end{aligned}
$$

Apresentam-se os dados para a cultura do milho.

\section{Decomposição do efeito área em efeitos escala e substituição no subperíodo.}

1980-1985:
$A_{c i}=89.698$
$A_{c f}=240.190$
$A_{i}=997.295$
$A_{f}=1.518 .281$
$\lambda=1,5224$

1985-1990:
$A_{c i}=240.190$
$A_{c f}=286.723$
$A_{i}=1.518 .281$
$A_{f}=2.227 .343$
$\lambda=1,46702$

1990-1995:
$A_{c i}=286.723$
$A_{c f}=472.244$
$A_{i}=2.227 .343$
$A_{f}=3.077 .295$
$\lambda=1,3816$

1995-2000:
$A_{c i}=472.244$
$A_{c f}=506.275$
$A_{i}=3.077 .295$
$A_{f}=4.309 .169$
$\lambda=1,40031$

1980-2000:
$A_{c i}=89.698$
$A_{c f}=506.275$
$A_{i}=997.295$
$A_{f}=4.309 .169$
$\lambda=4,32086$ 


\section{Análise individual da cultura do milho}

1980-1985:
$A_{c i}=89.698$
$A_{c f}=240.190$
$Q_{C i}=140.670$
$Q_{c f}=413.663$
$Q_{c f}^{A}=25.264$
$Q_{c f}^{A R}=431.111$
$Q_{c f}^{A R L}=413.663$

1985-1990:
$A_{c i}=240.190$
$A_{c f}=286.723$
$Q_{C i}=413.663$
$Q_{c f}=693.598$
$Q_{c f}^{A}=493.804$
$Q_{c f}^{A R}=586.379$
$Q_{c f}^{A R L}=693.598$

1990-1995:

$A_{c i}=286.723$

$A_{c f}=472.244$

$Q_{C i}=693.598$

$Q_{c f}=1.296 .798$

$Q_{c f}^{A}=1.142 .384$

$Q_{c f}^{A R}=1.234 .357$

$Q_{c f}^{A R L}=1.296 .798$

1995-2000:
$A_{c i}=472.244$
$A_{c f}=506.275$
$Q_{C i}=1.296 .798$
$Q_{C f}=1.422 .183$
$Q_{c f}^{A}=1.390 .249$
$Q_{c f}^{A R}=1.457 .522$
1980-2000:
$A_{c i}=89.698$
$A_{c f}=506.275$
$Q_{C i}=140.670$
$Q_{c f}=1.422 .183$

$Q_{c f}^{A R L}=1.422 .183$ 
$Q_{c f}^{A}=793.968 \quad Q_{c f}^{A R}=1.425 .007 \quad Q_{c f}^{A R L}=1.422 .183$

Apresentam-se os dados para a cultura da soja.

Decomposição do efeito área em efeitos escala e substituição no subperíodo. 1980-1985:
$A_{c i}=69.883$
$A_{c f}=748.943$
$A_{i}=997.295$
$A_{f}=1.518 .281$
$\lambda=1,5224$

1985-1990:

$A_{c i}=748.943$

$A_{c f}=1.465 .329$

$A_{i}=1.518 .281$

$A_{f}=2.227 .343$

$\lambda=1,46702$

1990-1995:

$A_{c i}=1.465 .329$

$A_{c f}=2.100 .643$

$A_{i}=2.227 .343$

$A_{f}=3.077 .295$

$\lambda=1,3816$

1995-2000:
$A_{c i}=2.100 .643$
$A_{c f}=2.887 .604$
$A_{i}=3.077 .295$
$A_{f}=4.309 .169$
$\lambda=1,40031$

1980-2000:

$$
\begin{aligned}
& A_{c i}=69.883 \\
& A_{i}=997.295
\end{aligned}
$$

$A_{c f}=2.887 .604$

$A_{f}=4.309 .169$

$\lambda=4,32086$ 


\section{Análise individual da cultura da soja}

1980-1985:
$A_{c i}=69.883$
$A_{c f}=748.943$
$Q_{C i}=112.167$
$Q_{c f}=1.533 .383$
$Q_{c f}^{A}=24.066$
$Q_{c f}^{A R}=1.551 .599$

$Q_{c f}^{A R L}=1.533 .383$

1985-1990:
$A_{c i}=748.943$
$A_{c f}=1.465 .329$
$Q_{C i}=1.533 .383$
$Q_{c f}=3.215 .824$
$Q_{c f}^{A}=3.000 .110$
$Q_{c f}^{A R}=3.221 .962$
$Q_{c f}^{A R L}=3.215 .824$

1990-1995:
$A_{c i}=1.465 .329$
$A_{c f}=2.100 .643$
$Q_{C i}=3.215 .824$
$Q_{C f}=5.298 .669$
$Q_{c f}^{A}=4.610 .088$
$Q_{c f}^{A R}=5.280 .020$
$Q_{c f}^{A R L}=5.298 .669$

1995-2000:
$A_{c i}=2.100 .643$
$A_{c f}=2.887 .604$
$Q_{C i}=5.298 .669$
$Q_{C f}=8.570 .048$
$Q_{c f}^{A}=7.283 .702$
$Q_{c f}^{A R}=8.580 .915$
1980-2000:
$A_{c i}=69.883$
$A_{c f}=2.887 .604$
$Q_{C i}=112.167$
$Q_{c f}=8.570 .048$

$Q_{C f}^{A R L}=8.570 .048$ 
$Q_{c f}^{A}=4.634 .789$

$Q_{c f}^{A R}=8.412 .843$

$Q_{c f}^{A R L}=8.570 .048$

Após a apresentação dos dados inerentes ao cálculo da decomposição do efeito área em efeitos escala e substituição e da análise individual das culturas no estado, procede-se a apresentação das informações referentes à análise do conjunto de culturas por microrregião e para o estado.

Os preços $(\mathrm{R} \$ / \mathrm{kg})$ das culturas do algodão, arroz, milho e soja são R \$ 0,33; $\mathrm{R}$ \$ 0,13; R\$ 0,08; R \$ 0,14, respectivamente. O valor da produção está descrito em R\$.

\section{Aripuanã}

1980-1985:
$A_{m i}=7.137$
$A_{m f}=28.586$
$V_{m i}=1.260 .979,71$
$V_{m f}=6.120 .808,20$
$V_{m f}^{A}=5.050 .455,78$
$V_{m f}^{A R}=6.355 .412,60$
$V_{m f}^{A R C}=6.120 .808,20$

1985-1990:
$A_{m i}=28.586$
$A_{m f}=47.285$
$V_{m i}=6.120 .808,20$
$V_{m f}=11.083 .803,84$
$V_{m f}^{A}=10.124 .502,93$
$V_{m f}^{A R}=8.810 .530,71$
$V_{m f}^{A R C}=11.083 .803,84$

1990-1995:
$A_{m i}=47.285$
$A_{m f}=45.805$
$V_{m i}=11.083 .803,84$
$V_{m f}=13.880 .910,79$
$V_{m f}^{A}=10.736 .807,45$
$V_{m f}^{A R}=13.470 .030,00$
$V_{m f}^{A R C}=13.880 .910,79$ 
1995-2000:

$$
\begin{aligned}
A_{m i} & =45.805 & & A_{m f}=93.847 \\
V_{m i} & =13.880 .910,79 & V_{m f} & =35.228 .327,32 \\
& V_{m f}^{A}=28.440 .038,02 & V_{m f}^{A R}=30.002 .209,73 & V_{m f}^{A R C}=35.228 .327,32
\end{aligned}
$$

1980-2000:

$$
\begin{array}{lll}
A_{m i}=7.137 & A_{m f}=93.847 & \\
V_{m i}=1.260 .979,71 & V_{m f}=35.228 .327,32 & \\
V_{m f}^{A}=16.580 .363,83 & V_{m f}^{A R}=23.914 .328,67 & V_{m f}^{A R C}=35.228 .327,32
\end{array}
$$

\section{Alta Floresta}

1980-1985:

$$
\begin{aligned}
& A_{m i}=1.568 \\
& A_{m f}=14.671 \\
& V_{m i}=97.457,61 \\
& V_{m f}=2.577 \cdot 137,27 \\
& V_{m f}^{A}=911.648,11 \\
& V_{m f}^{A R}=2.543 .180,72 \\
& V_{m f}^{A R C}=2.577 .137,27
\end{aligned}
$$

1985-1990:

$$
\begin{aligned}
& A_{m i}=14.671 \\
& A_{m f}=20.610 \\
& V_{m i}=2 \cdot 577 \cdot 137,27 \\
& V_{m f}=3.212 .258,17 \\
& V_{m f}^{A}=3.620 .534,73 \\
& V_{m f}^{A R}=3.103 .580,37 \\
& V_{m f}^{A R C}=3.212 .258,17
\end{aligned}
$$

1990-1995:

$$
\begin{array}{ll}
A_{m i}=20.610 & A_{m f}=30.418 \\
V_{m i}=3.212 .258,17 & V_{m f}=6.580 .363,43
\end{array}
$$


$V_{m f}^{A}=4.740 .796,60$

$V_{m f}^{A R}=6.409 .448,60$

$V_{m f}^{A R C}=6.580 .363,43$

1995-2000:

$A_{m i}=30.418$

$A_{m f}=36.130$

$V_{m i}=6.580 .363,43$

$V_{m f}=11.341 .996,70$

$V_{m f}^{A}=7.816 .133,09$

$V_{m f}^{A R}=11.010 .699,37$

$V_{m f}^{A R C}=11.341 .996,70$

1980-2000:

$A_{m i}=1.568$

$A_{m f}=36.130$

$V_{m i}=97.457,61$

$V_{m f}=11.341 .996,70$

$V_{m f}^{A}=2.245 .149,94$

$V_{m f}^{A R}=11.239 .151,39$

$V_{m f}^{A R C}=11.341 .996,70$

\section{Colíder}

1980-1985:

$A_{m i}=7.973$

$A_{m f}=99.698$

$V_{m i}=479.600,00$

$V_{m f}=13.031 .547,55$

$V_{m f}^{A}=5.996 .864,67$

$V_{m f}^{A R}=16.131 .224,00$

$V_{m f}^{A R C}=13.031 .547,55$

1985-1990:
$A_{m i}=99.698$
$A_{m f}=70.470$
$V_{m i}=13.031 \cdot 547,55$
$V_{m f}=13 \cdot 110.563,44$
$V_{m f}^{A}=9 \cdot 211.136,45$
$V_{m f}^{A R}=10.429 .815,60$
$V_{m f}^{A R C}=13.110 .563,44$

1990-1995:
$A_{m i}=70.470$
$A_{m f}=61.463$ 
$V_{m i}=13 \cdot 110.563,44$

$V_{m f}^{A}=11.434 .851,74$
$V_{m f}=11.324 .965,13$

$V_{m f}^{A R}=11.499 .738,20$

$V_{m f}^{A R C}=11.324 .965,13$

1995-2000:
$A_{m i}=61.463$
$A_{m f}=71.828$
$V_{m i}=11.324 .965,13$
$V_{m f}=25.518 .628,13$
$V_{m f}^{A}=13.234 .795,43$
$V_{m f}^{A R}=23 \cdot 218 \cdot 330,94$
$V_{m f}^{A R C}=25 \cdot 518 \cdot 628,13$

1980-2000:
$A_{m i}=7.973$
$A_{m f}=71.828$
$V_{m i}=479.600,00$
$V_{m f}=25.518 .628,13$
$V_{m f}^{A}=4.320 .470,18$
$V_{m f}^{A R}=24.960 .593,06$
$V_{m f}^{A R C}=25.518 .628,13$

\section{Parecis}

1980-1985:
$A_{m i}=79.979$
$A_{m f}=198.001$
$V_{m i}=14.448 .078,46$
$V_{m f}=51.638 .276,45$
$V_{m f}^{A}=35.768 .564,03$
$V_{m f}^{A R}=30.431 .023,21$
$V_{m f}^{A R C}=51 \cdot 638 \cdot 276,45$

1985-1990:
$A_{m i}=198.001$
$A_{m f}=421.949$
$V_{m i}=51 \cdot 638 \cdot 276,45$
$V_{m f}=120.766 .704,50$
$V_{m f}^{A}=110.043 .480,13$
$V_{m f}^{A R}=116.264 .435,88$
$V_{m f}^{A R C}=120.766 .704,50$ 
1990-1995:

$$
\begin{aligned}
& A_{m i}=421.949 \quad A_{m f}=688.179 \\
& V_{m i}=120.766 .704,50 \quad V_{m f}=234.401 .910,70 \\
& V_{m f}^{A}=196.964 .822,61 \quad V_{m f}^{A R}=235.301 .818,38 \quad V_{m f}^{A R C}=234.401 .910,70
\end{aligned}
$$

1995-2000:

$$
\begin{array}{lll}
A_{m i}=688.179 & A_{m f}=1.043 .602 & \\
V_{m i}=234.401 .910,70 & V_{m f}=453.355 .985,29 & \\
V_{m f}^{A}=355.463 .190,26 & V_{m f}^{A R}=405.693 .080,65 & V_{m f}^{A R C}=453.355 .985,29
\end{array}
$$

1980-2000:

$$
\begin{array}{lll}
A_{m i}=79.979 & A_{m f}=1.043 .602 & \\
V_{m i}=14.448 .078,46 & V_{m f}=453.355 .985,29 & \\
V_{m f}^{A}=188.525 .032,50 & V_{m f}^{A R}=337.093 .260,35 & V_{m f}^{A R C}=453.355 .985,29
\end{array}
$$

\section{Arinos}

1980-1985:

$$
\begin{aligned}
& A_{m i}=5.483 \\
& A_{m f}=33.761 \\
& V_{m i}=1.078 .196,23 \quad V_{m f}=5.476 .557,00 \\
& V_{m f}^{A}=6.638 .542,65 \quad V_{m f}^{A R}=5.348 .326,10 \quad V_{m f}^{A R C}=5.476 .557,00
\end{aligned}
$$

1985-1990:

$$
\begin{array}{ll}
A_{m i}=33.761 & A_{m f}=37.840 \\
V_{m i}=5.476 .557,00 & V_{m f}=7.939 .271,20
\end{array}
$$


$V_{m f}^{A}=6.138 .173,36 \quad V_{m f}^{A R}=6.858 .584,81 \quad V_{m f}^{A R C}=7.939 .271,20$

1990-1995:

$$
\begin{array}{lll}
A_{m i}=37.840 & & A_{m f}=42.484 \\
V_{m i}=7.939 .271,20 & V_{m f}=12.344 .380,51 & \\
V_{m f}^{A}=8.913 .566,36 & V_{m f}^{A R}=11.135 .617,88 & V_{m f}^{A R C}=12.344 .380,51
\end{array}
$$

1995-2000:

$$
\begin{aligned}
& A_{m i}=42.484 \quad A_{m f}=86.461 \\
& V_{m i}=12.344 .380,51 \quad V_{m f}=34.271 \cdot 211,40 \\
& V_{m f}^{A}=25.122 .869,14 \quad V_{m f}^{A R}=31.275 .170,41 \quad V_{m f}^{A R C}=34.271 .211,40
\end{aligned}
$$

1980-2000:

$$
\begin{array}{lll}
A_{m i}=5.483 & A_{m f}=86.461 & \\
V_{m i}=1.078 .196,23 & V_{m f}=34.271 .211,40 & \\
V_{m f}^{A}=17.001 .024,32 & V_{m f}^{A R}=28.944 .386,61 & V_{m f}^{A R C}=34.271 .211,40
\end{array}
$$

\section{Alto Teles Pires}

1980-1985:

$$
\begin{array}{lll}
A_{m i}=37.163 & A_{m f}=101.566 & \\
V_{m i}=6.679 .283,51 & V_{m f}=26.152 .344,83 & \\
V_{m f}^{A}=18.254 .499,56 & V_{m f}^{A R}=16.542 .965,45 & V_{m f}^{A R C}=26.152 .344,83
\end{array}
$$

1985-1990:

$$
A_{m i}=101.566 \quad A_{m f}=345.638
$$


$V_{m i}=26.152 .344,83$

$V_{m f}^{A}=88.998 .927,90$
$V_{m f}=99.859 .426,64$

$V_{m f}^{A R}=94.046 .429,69$

1990-1995:
$A_{m i}=345.638$
$A_{m f}=672.570$
$V_{m i}=99.859 .426,64$
$V_{m f}=213.875 .055,58$
$V_{m f}^{A}=194.314 .627,88$
$V_{m f}^{A R}=227.590 .026,77$
$V_{m f}^{A R C}=213.875 .055,58$

1995-2000:
$A_{m i}=672.570$
$A_{m f}=1.190 .777$
$V_{m i}=213.875 .055,58$
$V_{m f}=489.207 .814,64$
$V_{m f}^{A}=378.663 .289,11$
$V_{m f}^{A R}=459.073 .189,55$
$V_{m f}^{A R C}=489.207 .814,64$

1980-2000:
$A_{m i}=37.163$
$A_{m f}=1.190 .777$
$V_{m i}=6.679 .283,51$
$V_{m f}=489.207 .814,64$
$V_{m f}^{A}=214.019 .609,44$
$V_{m f}^{A R}=427.752 .454,94$
$V_{m f}^{A R C}=489.207 .814,64$

\section{Sinop}

1980-1985:
$A_{m i}=1.367$
$A_{m f}=18.255$
$V_{m i}=53.500,00$
$V_{m f}=3.397 .628,19$
$V_{m f}^{A}=714.616,46$
$V_{m f}^{A R}=3.163 .397,93$
$V_{m f}^{A R C}=3.397 .628,19$ 
1985-1990:

$$
\begin{array}{llrl}
A_{m i} & =18.255 & & A_{m f}=25.124 \\
V_{m i} & =3.397 .628,19 & V_{m f} & =5.413 .413,70 \\
& V_{m f}^{A}=4.676 .151,37 & V_{m f}^{A R} & =4.739 .423,23
\end{array}
$$

1990-1995:

$$
\begin{array}{llrl}
A_{m i} & =25.124 & & A_{m f}=33.476 \\
V_{m i} & =5.413 .413,70 & V_{m f} & =9.548 .059,10 \\
V_{m f}^{A} & =7.212 .905,29 & V_{m f}^{A R} & =9.924 .950,01
\end{array}
$$

1995-2000:

$$
\begin{aligned}
& A_{m i}=33.476 \quad A_{m f}=110.386 \\
& V_{m i}=9.548 .059,10 \quad V_{m f}=43.075 .624,97 \\
& V_{m f}^{A}=31.484 .408,30 \quad V_{m f}^{A R}=39.048 .072,86 \quad V_{m f}^{A R C}=43.075 .624,97
\end{aligned}
$$

1980-2000:

$$
\begin{aligned}
& A_{m i}=1.367 \\
& A_{m f}=110.386 \\
& V_{m i}=53.500,00 \\
& V_{m f}=43 \cdot 075 \cdot 624,97 \\
& V_{m f}^{A}=4 \cdot 321 \cdot 208,05 \\
& V_{m f}^{A R}=39.285 .030,28 \\
& V_{m f}^{A R C}=43.075 .624,97
\end{aligned}
$$

\section{Paranatinga}

1980-1985:

$$
\begin{array}{ll}
A_{m i}=12.063 & A_{m f}=36.459 \\
V_{m i}=714.870,00 & V_{m f}=5.554 .152,06
\end{array}
$$


$V_{m f}^{A}=2.160 .690,03$

$V_{m f}^{A R}=5.515 .518,87$

$V_{m f}^{A R C}=5.554 .152,06$

1985-1990:

$A_{m i}=36.459$

$A_{m f}=38.794$

$V_{m i}=5.554 .152,06$

$V_{m f}=7.946 .467,12$

$V_{m f}^{A}=5.909 .760,38$

$V_{m f}^{A R}=7.758 .133,86$

$V_{m f}^{A R C}=7.946 .467,12$

1990-1995:

$A_{m i}=38.794$

$A_{m f}=59.233$

$V_{m i}=7.946 .467,12$

$V_{m f}=12.149 .939,34$

$V_{m f}^{A}=12 \cdot 133.313,92$

$V_{m f}^{A R}=12.821 .941,64$

$V_{m f}^{A R C}=12.149 .939,34$

1995-2000:
$A_{m i}=59.233$
$A_{m f}=75.910$
$V_{m i}=12 \cdot 149.939,34$
$V_{m f}=22.206 .178,83$
$V_{m f}^{A}=15.570 .725,02$
$V_{m f}^{A R}=21.252 .624,13$
$V_{m f}^{A R C}=22.206 .178,83$

1980-2000:
$A_{m i}=12.063$
$A_{m f}=75.910$
$V_{m i}=714.870,00$
$V_{m f}=22.206 .178,83$
$V_{m f}^{A}=4.498 .675,25$
$V_{m f}^{A R}=20.907 .446,49$
$V_{m f}^{A R C}=22.206 .178,83$

\section{Norte Araguaia}

1980-1985:
$A_{m i}=16.235$
$A_{m f}=35.513$ 
$V_{m i}=2.444 .772,55$

$V_{m f}^{A}=5.347 .889,76$

1985-1990:

$A_{m i}=35.513$

$V_{m i}=5.944 .047,60$

$V_{m f}^{A}=8.671 .450,40$
$V_{m f}=5.944 .047,60$

$V_{m f}^{A R}=5.893 .149,42$

$V_{m f}^{A R C}=5.944 .047,60$

1990-1995:

$A_{m i}=51.808$

$A_{m f}=36.357$

$V_{m i}=8.060 .138,58$

$V_{m f}=6.103 .411,48$

$V_{m f}^{A}=5.656 .316,76$

$V_{m f}^{A R}=5.943 .029,22$

$$
\begin{aligned}
& A_{m f}=51.808 \\
& V_{m f}=8.060 .138,58 \\
& V_{m f}^{A R}=8.127 .310,83 \quad V_{m f}^{A R C}=8.060 .138,58
\end{aligned}
$$

1995-2000:

$$
\begin{aligned}
& A_{m i}=36.357 \\
& V_{m i}=6.103 .411,48 \\
& V_{m f}^{A}=8.062 .898,05
\end{aligned}
$$$$
A_{m f}=48.029
$$$$
V_{m f}=9.229 .032,87
$$

$V_{m f}^{A R}=9.221 .567,37$

$V_{m f}^{A R C}=6.103 .411,48$

1980-2000:

$$
\begin{aligned}
& A_{m i}=16.235 \\
& V_{m i}=2.444 .772,55 \\
& V_{m f}^{A}=7.232 .719,84
\end{aligned}
$$$$
A_{m f}=48.029
$$$$
V_{m f}=9.229 .032,87
$$$$
V_{m f}^{A R}=9.802 .448,09
$$$$
V_{m f}^{A R C}=9.229 .032,87
$$ 


\section{Canarana}

1980-1985:

$$
\begin{aligned}
& A_{m i}=44.155 \quad A_{m f}=100.013 \\
& V_{m i}=1.170 .590,00 \quad V_{m f}=17.426 .783,87 \\
& V_{m f}^{A}=2.651 .446,22 \quad V_{m f}^{A R}=13.516 .014,16 \quad V_{m f}^{A R C}=17.426 .783,87
\end{aligned}
$$

1985-1990:

$$
\begin{aligned}
& A_{m i}=100.013 \quad A_{m f}=208.057 \\
& V_{m i}=17.426 .783,87 \quad V_{m f}=45.155 .409,20 \\
& V_{m f}^{A}=36.252 .810,01 \quad V_{m f}^{A R}=42.063 .834,90 \quad V_{m f}^{A R C}=45.155 .409,20
\end{aligned}
$$

1990-1995:

$$
\begin{array}{rlrl}
A_{m i} & =208.057 & & A_{m f}=255.516 \\
V_{m i}=45.155 .409,20 & V_{m f}=75.874 .783,76 \\
V_{m f}^{A}=55.455 .545,76 & V_{m f}^{A R}=72.529 .791,30 & V_{m f}^{A R C}=75.874 .783,76
\end{array}
$$

1995-2000:

$$
\begin{aligned}
& A_{m i}=255.516 \quad A_{m f}=294.235 \\
& V_{m i}=75.874 .783,76 \quad V_{m f}=132.867 .647,10 \\
& V_{m f}^{A}=87.372 .300,88 \quad V_{m f}^{A R}=109.184 .589,06 \quad V_{m f}^{A R C}=132.867 .647,10
\end{aligned}
$$

1980-2000:

$$
\begin{array}{ll}
A_{m i}=44.155 & A_{m f}=294.235 \\
V_{m i}=1.170 .590,00 & V_{m f}=132.867 .647,10
\end{array}
$$


$V_{m f}^{A}=7.800 .433,89$

$V_{m f}^{A R}=87.915 .776,70$

$V_{m f}^{A R C}=132.867 .647,10$

\section{Médio Araguaia}

1980-1985:
$A_{m i}=172.402$
$A_{m f}=34.761$
$V_{m i}=24.651 .138,72$
$V_{m f}=6.168 .628,68$
$V_{m f}^{A}=4.970 .397,39$
$V_{m f}^{A R}=4.508 .534,90$
$V_{m f}^{A R C}=6.168 .628,68$

1985-1990:
$A_{m i}=34.761$
$A_{m f}=30.421$
$V_{m i}=6.168 .628,68$
$V_{m f}=6.281 .187,16$
$V_{m f}^{A}=5.398 .466,95$
$V_{m f}^{A R}=6.299 .580,66$
$V_{m f}^{A R C}=6.281 .187,16$

1990-1995:
$A_{m i}=30.421$
$A_{m f}=15.749$
$V_{m i}=6 \cdot 281 \cdot 187,16$
$V_{m f}=3.519 .336,45$
$V_{m f}^{A}=3.251 .676,11$
$V_{m f}^{A R}=3.611 .275,48$
$V_{m f}^{A R C}=3.519 .336,45$

1995-2000:
$A_{m i}=15.749$
$A_{m f}=9.416$
$V_{m i}=3 \cdot 519.336,45$
$V_{m f}=2.513 .501,75$
$V_{m f}^{A}=2.104 .108,22$
$V_{m f}^{A R}=2.337 .093,75$
$V_{m f}^{A R C}=2.513 .501,75$

1980-2000:
$A_{m i}=172.402$
$A_{m f}=9.416$ 


$$
\begin{aligned}
& V_{m i}=24.651 .138,72 \quad V_{m f}=2.513 .501,75 \\
& V_{m f}^{A}=1.346 .312,14 \quad V_{m f}^{A R}=2.130 .885,93 \quad V_{m f}^{A R C}=2.513 .501,75
\end{aligned}
$$

\section{Alto Guaporé}

1980-1985:

$$
\begin{aligned}
& A_{m i}=15.955 \quad A_{m f}=38.445 \\
& V_{m i}=2.722 .775,66 \quad V_{m f}=6.105 .635,48 \\
& V_{m f}^{A}=6.560 .908,62 \quad V_{m f}^{A R}=5.930 .620,60 \quad V_{m f}^{A R C}=6.105 .635,48
\end{aligned}
$$

1985-1990:

$$
\begin{aligned}
& A_{m i}=38.445 \quad A_{m f}=14.171 \\
& V_{m i}=6.105 .635,48 \quad V_{m f}=2.431 .122,59 \\
& V_{m f}^{A}=2.250 .564,71 \quad V_{m f}^{A R}=2.253 .455,96 \quad V_{m f}^{A R C}=2.431 .122,59
\end{aligned}
$$

1990-1995:

$$
\begin{aligned}
& A_{m i}=14.171 \quad A_{m f}=16.712 \\
& V_{m i}=2.431 .122,59 \quad V_{m f}=3.332 .743,73 \\
& V_{m f}^{A}=2.867 .104,02 \quad V_{m f}^{A R}=3.427 .306,74 \quad V_{m f}^{A R C}=3.332 .743,73
\end{aligned}
$$

1995-2000:

$$
\begin{aligned}
& A_{m i}=16.712 \quad A_{m f}=10.131 \\
& V_{m i}=3.332 .743,73 \quad V_{m f}=2.524 .895,62 \\
& V_{m f}^{A}=2.020 .305,97 \quad V_{m f}^{A R}=2.694 .297,53 \quad V_{m f}^{A R C}=2.524 .895,62
\end{aligned}
$$


1980-2000:
$A_{m i}=15.955$
$A_{m f}=10.131$
$V_{m i}=2.722 .775,66$
$V_{m f}=2.524 .895,62$
$V_{m f}^{A}=1.728 .926,14$
$V_{m f}^{A R}=2.337 .137,22$
$V_{m f}^{A R C}=2.524 .895,62$

\section{Tangará da Serra}

1980-1985:
$A_{m i}=32.828$
$A_{m f}=28.379$
$V_{m i}=5.708 .643,26$
$V_{m f}=5.679 .805,33$
$V_{m f}^{A}=4.934 .931,83$
$V_{m f}^{A R}=5.222 .438,80$
$V_{m f}^{A R C}=5.679 .805,33$

1985-1990:
$A_{m i}=28.379$
$A_{m f}=50.074$
$V_{m i}=5 \cdot 679.805,33$
$V_{m f}=13.048 .484,84$
$V_{m f}^{A}=10.021 .800,58$
$V_{m f}^{A R}=12.332 .835,84$
$V_{m f}^{A R C}=13.048 .484,84$

1990-1995:
$A_{m i}=50.074$
$A_{m f}=47.996$
$V_{m i}=13 \cdot 048 \cdot 484,84$
$V_{m f}=15.302 .824,35$
$V_{m f}^{A}=12.507 .074,48$
$V_{m f}^{A R}=14 \cdot 209 \cdot 126,20$
1995-2000:
$A_{m i}=47.996$
$A_{m f}=48.454$
$V_{m i}=15 \cdot 302 \cdot 824,35$
$V_{m f}=18.126 .649,52$

$V_{m f}^{A R C}=15.302 .824,35$ 
$V_{m f}^{A}=15.448 .957,24 \quad V_{m f}^{A R}=18.924 .674,51 \quad V_{m f}^{A R C}=18.126 .649,52$

1980-2000:

$$
\begin{aligned}
& A_{m i}=32.828 \quad A_{m f}=48.454 \\
& V_{m i}=5.708 .643,26 \quad V_{m f}=18.126 .649,52 \\
& V_{m f}^{A}=8.425 .907,60 \quad V_{m f}^{A R}=16.076 .308,35 \quad V_{m f}^{A R C}=18.126 .649,52
\end{aligned}
$$

\section{Jauru}

1980-1985:

$A_{m i}=52.012$

$A_{m f}=59.785$

$V_{m i}=9 \cdot 761.028,26$

$V_{m f}=10.409 .049,15$

$V_{m f}^{A}=11.219 .715,08$

$V_{m f}^{A R}=10.899 .857,61$

$V_{m f}^{A R C}=10.409 .049,15$

1985-1990:

$$
\begin{array}{lll}
A_{m i}=59.785 & A_{m f}=57.714 & \\
V_{m i}=10.409 .049,15 & V_{m f}=13.710 .053,61 & \\
V_{m f}^{A}=10.048 .527,43 & V_{m f}^{A R}=10.781 .201,29 & V_{m f}^{A R C}=13.710 .053,61
\end{array}
$$

1990-1995:

$$
\begin{aligned}
& A_{m i}=57.714 \\
& A_{m f}=51.240 \\
& V_{m i}=13.710 .053,61 \\
& V_{m f}=13.890 .542,13 \\
& V_{m f}^{A}=12.172 .144,49 \\
& V_{m f}^{A R}=12.397 .648,30 \\
& V_{m f}^{A R C}=13.890 .542,13
\end{aligned}
$$

1995-2000:

$$
A_{m i}=51.240 \quad A_{m f}=23.726
$$


$V_{m i}=13.890 .542,13$

$V_{m f}^{A}=6.431 .830,65$

1980-2000:

$A_{m i}=52.012$

$V_{m i}=9.761 .028,26$

$V_{m f}^{A}=4.452 .629,32$
$V_{m f}=6 \cdot 154.716,48$

$V_{m f}^{A R}=8.762 .709,03$

$V_{m f}^{A R C}=6.154 .716,48$

\section{Alto Paraguai}

1980-1985:

$$
\begin{array}{ll}
A_{m i}=17.284 & A_{m f}=14.434 \\
V_{m i}=2.932 .678,44 & V_{m f}=2.857 .797,96
\end{array}
$$

$V_{m f}^{A}=2.449 .054,86$

$$
\begin{aligned}
A_{m f} & =23.726 \\
V_{m f} & =6.154 .716,48 \\
V_{m f}^{A R} & =5.631 .742,59
\end{aligned}
$$$$
V_{m f}^{A R C}=6.154 .716,48
$$

1985-1990:

$$
\begin{aligned}
A_{m i} & =14.434 & & A_{m f}=15.865 \\
V_{m i} & =2.857 .797,96 & V_{m f} & =3.715 .224,08 \\
& V_{m f}^{A}=3.141 .056,67 & V_{m f}^{A R} & =3.255 .599,39
\end{aligned}
$$$$
V_{m f}^{A R C}=2.857 .797,96
$$

1990-1995:

$$
\begin{aligned}
A_{m i} & =15.865 & & A_{m f}=20.194 \\
V_{m i} & =3.715 .224,08 & V_{m f} & =5.878 .918,91 \\
V_{m f}^{A} & =4.729 .155,37 & V_{m f}^{A R} & =5.558 .232,25
\end{aligned}
$$


1995-2000:

$$
\begin{aligned}
& A_{m i}=20.194 \\
& A_{m f}=32.744 \\
& V_{m i}=5.878 .918,91 \\
& V_{m f}=11.843 .620,74 \\
& V_{m f}^{A}=9.532 .440,48 \\
& V_{m f}^{A R}=12.155 .839,67 \\
& V_{m f}^{A R C}=11.843 .620,74
\end{aligned}
$$

1980-2000:

$$
\begin{array}{llrl}
A_{m i} & =17.284 & & A_{m f}=32.744 \\
V_{m i} & =2.932 .678,44 & & V_{m f}=11.843 .620,74 \\
V_{m f}^{A} & =5.555 .817,43 & V_{m f}^{A R}=11.903 .967,30 & V_{m f}^{A R C}=11.843 .620,74
\end{array}
$$

\section{Rosário Oeste}

1980-1985:

$$
\begin{aligned}
A_{m i} & =16.713 & A_{m f} & =22.894 \\
V_{m i} & =2.795 .425,04 & V_{m f} & =4.616 .519,99 \\
& V_{m f}^{A}=3.829 .282,93 & V_{m f}^{A R} & =4.005 .652,02
\end{aligned}
$$

1985-1990:

$$
\begin{array}{ll}
A_{m i}=22.894 & A_{m f}=14.415 \\
V_{m i}=4.616 .519,99 & V_{m f}=3.446 .440,67 \\
V_{m f}^{A}=2.906 .859,59 & V_{m f}^{A R}=3.187 .040,23 \\
1990-1995: & \\
A_{m i}=14.415 & A_{m f}=6.170 \\
V_{m i}=3.446 .440,67 & V_{m f}=1.197 .072,44
\end{array}
$$$$
V_{m f}^{A R C}=3.446 .440,67
$$ 
$V_{m f}^{A}=1.475 .053,65$

$V_{m f}^{A R}=1.241 .374,74$

$V_{m f}^{A R C}=1.197 .072,44$

1995-2000:

$$
A_{m i}=6.170
$$

$A_{m f}=5.011$

$V_{m i}=1 \cdot 197 \cdot 072,44$

$V_{m f}=1.188 .123,43$

$V_{m f}^{A}=972.261,60$

$V_{m f}^{A R}=1.005 .296,38$

$V_{m f}^{A R C}=1.188 .123,43$

1980-2000:
$A_{m i}=16.713$
$A_{m f}=5.011$
$V_{m i}=2.795 .425,04$
$V_{m f}=1 \cdot 188.123,43$
$V_{m f}^{A}=838.159,17$
$V_{m f}^{A R}=1.035 .248,98$
$V_{m f}^{A R C}=1.188 .123,43$

\section{Cuiabá}

1980-1985:

$$
\begin{aligned}
& A_{m i}=118.299 \\
& A_{m f}=115.225 \\
& V_{m i}=20.290 .736,01 \\
& V_{m f}=27 \cdot 142 \cdot 250,83 \\
& V_{m f}^{A}=19.763 .481,15 \\
& V_{m f}^{A R}=20.587 .662,96 \\
& V_{m f}^{A R C}=27 \cdot 142 \cdot 250,83
\end{aligned}
$$

1985-1990:

$$
\begin{aligned}
A_{m i} & =115.225 & & A_{m f}=24.229 \\
V_{m i} & =27.142 .250,83 & V_{m f} & =5.088 .656,15 \\
V_{m f}^{A} & =5.707 .351,66 & V_{m f}^{A R} & =5.840 .271,00
\end{aligned}
$$

1990-1995:

$$
A_{m i}=24.229 \quad A_{m f}=18.724
$$


$V_{m i}=5.088 .656,15$

$V_{m f}^{A}=3.932 .407,51$

1995-2000:

$A_{m i}=18.724$

$V_{m i}=4 \cdot 256.489,18$

$V_{m f}^{A}=4.152 .143,78$

1980-2000:

$A_{m i}=118.299$

$V_{m i}=20.290 .736,01$

$V_{m f}^{A}=3.132 .769,76$
$V_{m f}=4.256 .489,18$

$V_{m f}^{A R}=4.561 .061,45$

$V_{m f}^{A R C}=4.256 .489,18$
$A_{m f}=18.265$

$V_{m f}=5.713 .182,63$

$V_{m f}^{A R}=4.724 .670,02$

$V_{m f}^{A R C}=5.713 .182,63$

\section{Alto Pantanal}

1980-1985:
$A_{m i}=49.068$
$A_{m f}=63.876$
$V_{m i}=8.844 .338,89$
$V_{m f}=10.091 .046,05$
$V_{m f}^{A}=11.513 .508,37$
$V_{m f}^{A R}=9.750 .034,36$
$V_{m f}^{A R C}=10.091 .046,05$

1985-1990:
$A_{m i}=63.876$
$A_{m f}=27.496$
$V_{m i}=10.091 .046,05$
$V_{m f}=5.057 .123,84$
$V_{m f}^{A}=4.343 .729,08$
$V_{m f}^{A R}=4.220 .921,26$
$V_{m f}^{A R C}=5.057 .123,84$ 
1990-1995:
$A_{m i}=27.496$
$A_{m f}=18.822$
$V_{m i}=5.057 .123,84$
$V_{m f}=4.323 .651,24$
$V_{m f}^{A}=3.461 .886,26$
$V_{m f}^{A R}=3.813 .854,67$
$V_{m f}^{A R C}=4.323 .651,24$

1995-2000:

$A_{m i}=18.822$

$A_{m f}=9.532$

$V_{m i}=4.323 .651,24$

$V_{m f}=2.241 .586,42$

$V_{m f}^{A}=2.189 .658,64$

$V_{m f}^{A R}=2.994 .124,22$

$V_{m f}^{A R C}=2.241 .586,42$

1980-2000:
$A_{m i}=49.068$
$A_{m f}=9.532$
$V_{m i}=8.844 .338,89$
$V_{m f}=2.241 .586,42$
$V_{m f}^{A}=1.718 .182,10$
$V_{m f}^{A R}=2.307 .804,74$
$V_{m f}^{A R C}=2.241 .586,42$

\section{Primavera do Leste}

1990-1995:
$A_{m i}=251.646$
$A_{m f}=333.851$
$V_{m i}=78 \cdot 278 \cdot 352,90$
$V_{m f}=112.458 .433,18$
$V_{m f}^{A}=103.849 .446,72$
$V_{m f}^{A R}=114.256 .290,63$
$V_{m f}^{A R C}=112.458 .433,18$

1995-2000:
$A_{m i}=333.851$
$A_{m f}=384.963$
$V_{m i}=112.458 .433,18$
$V_{m f}=203.355 .520,40$ 
$V_{m f}^{A}=129.675 .379,44 \quad V_{m f}^{A R}=153.467 .703,93 \quad V_{m f}^{A R C}=203.355 .520,40$

\section{Tesouro}

1980-1985:

$$
\begin{array}{lll}
A_{m i}=76.007 & A_{m f}=117.176 & \\
V_{m i}=11.441 .314,41 & V_{m f}=27.823 .975,82 & \\
V_{m f}^{A}=17.638 .423,35 & V_{m f}^{A R}=17.597 .674,11 & V_{m f}^{A R C}=27.823 .975,82
\end{array}
$$

1985-1990:

$$
\begin{array}{lll}
A_{m i}=117.176 & A_{m f}=82.077 & \\
V_{m i}=27.823 .975,82 & V_{m f}=22.909 .473,71 & \\
V_{m f}^{A}=19.489 .534,42 & V_{m f}^{A R}=21.456 .410,22 & V_{m f}^{A R C}=22.909 .473,71
\end{array}
$$

1990-1995:

$$
\begin{aligned}
& A_{m i}=82.077 \quad A_{m f}=130.256 \\
& V_{m i}=22.909 .473,71 \quad V_{m f}=41.080 .735,75 \\
& V_{m f}^{A}=36.357 .519,92 \quad V_{m f}^{A R}=40.845 .076,31 \quad V_{m f}^{A R C}=41.080 .735,75
\end{aligned}
$$

1995-2000:

$$
\begin{array}{llrl}
A_{m i} & =130.256 & A_{m f} & =170.545 \\
V_{m i} & =41.080 .735,75 & V_{m f} & =70.403 .501,07 \\
& V_{m f}^{A}=53.787 .233,16 & V_{m f}^{A R}=64.523 .574,61 & V_{m f}^{A R C}=70.403 .501,07
\end{array}
$$

1980-2000:

$$
A_{m i}=76.007 \quad A_{m f}=170.545
$$


$V_{m i}=11.441 .314,41$

$V_{m f}^{A}=25.672 .145,73$
$V_{m f}=70.403 .501,07$

$V_{m f}^{A R}=41.985 .973,81$

\section{Rondonópolis}

1980-1985:

$$
\begin{array}{llrl}
A_{m i} & =192.150 & & A_{m f}=259.875 \\
V_{m i}=32.371 .615,52 & V_{m f}=72.387 .921,54 & \\
V_{m f}^{A}=43.781 .227,13 & V_{m f}^{A R}=50.321 .489,31 & V_{m f}^{A R C}=72.387 .921,54
\end{array}
$$

1985-1990:

$$
\begin{aligned}
A_{m i} & =259.875 & & A_{m f}=283.971 \\
V_{m i} & =72.387 .921,54 & V_{m f} & =91.288 .438,46 \\
& V_{m f}^{A}=79.100 .032,57 & V_{m f}^{A R} & =86.631 .402,30
\end{aligned}
$$

1990-1995:

$$
\begin{aligned}
A_{m i} & =283.971 & & A_{m f}=362.394 \\
V_{m i} & =91.288 .438,46 & V_{m f} & =126.565 .666,97 \\
& V_{m f}^{A}=116.499 .128,31 & V_{m f}^{A R}=127.094 .375,99 & V_{m f}^{A R C}=126.565 .666,97
\end{aligned}
$$

1995-2000:

$$
\begin{aligned}
& A_{m i}=362.394 \\
& A_{m f}=374.353 \\
& V_{m i}=126.565 .666,97 \\
& V_{m f}=202 \cdot 179.348,84 \\
& V_{m f}^{A}=130.742 .329,43 \\
& V_{m f}^{A R}=156.356 .109,45 \\
& V_{m f}^{A R C}=202 \cdot 179 \cdot 348,84
\end{aligned}
$$


1980-2000:

$$
\begin{aligned}
& A_{m i}=192.150 \\
& A_{m f}=374.353 \\
& V_{m i}=32.371 .615,52 \\
& V_{m f}=202 \cdot 179.348,84 \\
& V_{m f}^{A}=63.067 .510,67 \\
& V_{m f}^{A R}=112.681 .807,10 \\
& V_{m f}^{A R C}=202 \cdot 179.348,84
\end{aligned}
$$

\section{Alto Araguaia}

1980-1985:

$$
\begin{aligned}
& A_{m i}=41.493 \\
& A_{m f}=96.908 \\
& V_{m i}=7 \cdot 428.715,74 \\
& V_{m f}=26.509 .365,72 \\
& V_{m f}^{A}=17.350 .021,97 \\
& V_{m f}^{A R}=19.293 .712,03 \\
& V_{m f}^{A R C}=26.509 .365,72
\end{aligned}
$$

1985-1990:

$$
\begin{aligned}
& A_{m i}=96.908 \\
& A_{m f}=107.689 \\
& V_{m i}=26.509 .365,72 \\
& V_{m f}=35.673 .059,00 \\
& V_{m f}^{A}=29.458 .427,23 \\
& V_{m f}^{A R}=34.550 .178,82 \\
& V_{m f}^{A R C}=35.673 .059,00
\end{aligned}
$$

1990-1995:

$$
\begin{array}{llrl}
A_{m i} & =107.689 & & A_{m f}=129.687 \\
V_{m i}=35.673 .059,00 & V_{m f}=44.072 .930,93 & \\
V_{m f}^{A}=42.960 .006,24 & V_{m f}^{A R}=44.105 .724,20 & V_{m f}^{A R C}=44.072 .930,93
\end{array}
$$

1995-2000:

$$
\begin{array}{ll}
A_{m i}=129.687 & A_{m f}=170.822 \\
V_{m i}=44.072 .930,93 & V_{m f}=79.034 .704,00
\end{array}
$$


$V_{m f}^{A}=58.052 .543,81 \quad V_{m f}^{A R}=69.317 .952,01 \quad V_{m f}^{A R C}=79.034 .704,00$

1980-2000:

$$
\begin{array}{lll}
A_{m i}=41.493 & A_{m f}=170.822 & \\
V_{m i}=7.428 .715,74 & V_{m f}=79.034 .704,00 & \\
V_{m f}^{A}=30.583 .244,33 & V_{m f}^{A R}=58.940 .977,54 & V_{m f}^{A R C}=79.034 .704,00
\end{array}
$$

\section{Estado}

1980-1985:

$$
\begin{array}{ll}
A_{i}=997.295 & A_{f}=1.518 .281 \\
V_{i}=157.553 .783,24 & V_{f}=354.307 .950,59 \\
V_{f}^{A}=239.859 .603,33 & V_{f}^{A R}=261.959 .158,56 \\
V_{f}^{A R L}=281.094 .749,43 & V_{f}^{A R L C}=354.307 .950,59
\end{array}
$$

1985-1990:

$$
\begin{array}{ll}
A_{i}=1.518 .281 & A_{f}=2.227 .343 \\
V_{i}=354.307 .950,59 & V_{f}=603.475 .073,41 \\
V_{f}^{A}=519.775 .580,90 & V_{f}^{A R}=529.417 .496,19 \\
V_{f}^{A R L}=493.010 .976,85 & V_{f}^{A R L C}=603.475 .073,41
\end{array}
$$

1990-1995:

$$
\begin{array}{ll}
A_{i}=2.227 .343 & A_{f}=3.077 .295 \\
V_{i}=603.475 .073,41 & V_{f}=971.963 .125,09 \\
V_{f}^{A}=833.760 .810,57 & V_{f}^{A R}=955.297 .593,89
\end{array}
$$


$V_{f}^{A R L}=981.747 .738,93 \quad V_{f}^{A R L C}=971.963 .125,09$

1995-2000:

$$
\begin{array}{ll}
A_{i}=3.077 .295 & A_{f}=4.309 .169 \\
V_{i}=971.963 .125,09 & V_{f}=1.861 .581 .798,15 \\
V_{f}^{A}=1.361 .050 .180,15 & V_{f}^{A R}=1.635 .648 .006,80 \\
V_{f}^{A R L}=1.636 .243 .579,20 & V_{f}^{A R L C}=1.861 .581 .798,15
\end{array}
$$

1980-2000:

$$
\begin{array}{ll}
A_{i}=997.295 & A_{f}=4.309 .169 \\
V_{i}=157.553 .783,24 & V_{f}=1.861 .581 .798,15 \\
V_{f}^{A}=680.767 .126,73 & V_{f}^{A R}=1.177 .924 .947,31 \\
V_{f}^{A R L}=1.270 .867 .841,61 & V_{f}^{A R L C}=1.861 .581 .798,15
\end{array}
$$

